\title{
BANCO DE SEMENTES AUTÓCTONE E ALÓCTONE, RESGATE DE PLANTAS E PLANTIO DE VEGETAÇÃO NATIVA NA FAZENDA INTERMONTES, MUNICÍPIO DE RIBEIRÃO GRANDE, SP
}

\section{ANDRÉ GUSTAVO NAVE}

Tese apresentada à Escola Superior de Agricultura

"Luiz de Queiroz", Universidade de São Paulo, para obtenção do título de Doutor em Recursos Florestais, com opção em Silvicultura e Manejo Florestal

P I R A C I C A B A

Estado de São Paulo - Brasil

Fevereiro - 2005 


\section{BANCO DE SEMENTES AUTÓCTONE E ALÓCTONE, RESGATE DE PLANTAS E PLANTIO DE VEGETAÇÃO NATIVA NA FAZENDA INTERMONTES, MUNICÍPIO DE RIBEIRÃO GRANDE, SP}

\section{ANDRÉ GuSTAVo NAVE}

Engenheiro Agrônomo

Orientador: Prof. Dr. RICARDO RIBEIRO RODRIGUES

Tese apresentada à Escola Superior de Agricultura

"Luiz de Queiroz", Universidade de São Paulo, para obtenção do título de Doutor em Recursos Florestais, com opção em Silvicultura e Manejo Florestal

P I R A C I C A B A

Estado de São Paulo - Brasil

Fevereiro - 2005 
Dados Internacionais de Catalogação na Publicação (CIP) DIVISÃO DE BIBLIOTECA E DOCUMENTAÇÃO - ESALQ/USP

\section{Nave, André Gustavo}

Banco de sementes autóctone e alóctone, resgate de plantas e plantio de vegetação nativa na Fazenda Intermontes, município de Ribeirão Grande, SP / André Gustavo Nave. - - Piracicaba, 2005.

218 p. : il.

Tese (Doutorado) - - Escola Superior de Agricultura Luiz de Queiroz, 2005. Bibliografia.

1. Alóctone 2. Autóctone 3. Banco de sementes 4. Diversidade vegetal 5. Plantas nativas 6 . Reabilitação de áreas degradadas I. Título

CDD 634.9

\section{"Permitida a cópia total ou parcial deste documento, desde que citada a fonte - O autor"}


Este trabalho é dedicado aos meus pais, a minha esposa e principalmente meus filhos Luca e Lara.

Também dedico este trabalho a todos meus companheiros do Laboratório de Ecologia e Restauração Florestal, os quais vários compartilharam momentos difíceis e felizes na elaboração deste trabalho. 


\section{AGRADECIMENTOS}

Á Companhia de Cimento Ribeirão Grande que acreditou, apoiou e forneceu a estrutura necessária para realização desse trabalho.

Á Escola Superior de Agricultura "Luiz de Queiroz", especialmente ao Laboratório de Ecologia e Restauração Florestal, pelo uso de suas instalações.

Ao Prof. Dr. Ricardo Ribeiro Rodrigues, o qual não só me orientou, mas sempre me incentivou e acreditou no meu trabalho.

Á minha esposa Gláucia e filhos Luca e Lara pelo amor e por terem perdido horas de convivência em função deste trabalho.

Aos amigos, Busato, Antônio Mauro, Paulo Gobbo, Paulo Henique, Cláudio, Gava, e funcionários da CCRG, que tanto colaboraram na realização deste trabalho.

Ao seu "Zé Paraná" da Fazenda Intermontes, pela ajuda nos experimentos e pelos "causos" que me contava durante o trabalho.

A todo o pessoal do parque Intervales, em especial a Jeanette, Maurício, Luci, Zé Froido, Diva, Zarife, os guias, as cozinheiras e vários outros que fizeram da minha estadia, momentos de descontração e alegria.

Ao seu João do viveiro da Intervales, pessoa bastante simples, mas com um conhecimento incrível sobre as plantas da região.

Ao amigo Edvaldo da Boa Vista, que sempre nos atendeu com muita simpatia para servir o famoso "gavião".

Ao Seu "Zé das sementes" pela iniciativa e dedicação à coleta e fornecimento de sementes de espécies nativas para produção de mudas desse trabalho, criando alternativas de trabalho para várias famílias carentes e ainda ajudando a preservar as florestas da região. 
Aos estagiários Vicente Bufo, Denis Arake, Lúcia Kitayama, Flávia Gava, Aline (Trinxa), Eduardo (JC), Maurício (Xatão), Cris Yuri e outros que me deram uma ajuda especial na coleta e organização dos dados.

Á Isa que me ajudou muito em outros trabalhos que não tive tempo de me dedicar.

Á minha sogra Janete Uliana, por ter feito a revisão ortográfica deste trabalho.

Á todos os professores, pós-graduandos, estagiários e funcionários do Departamento de Ciências Biológicas e de Ciências Florestais da ESALQ/USP que direta ou indiretamente contribuíram para realização desse trabalho. 
SUMÁRIO

Página

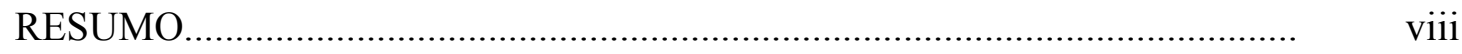

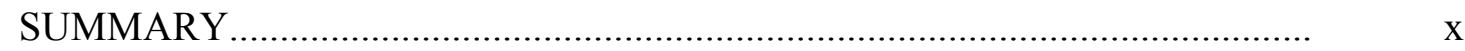

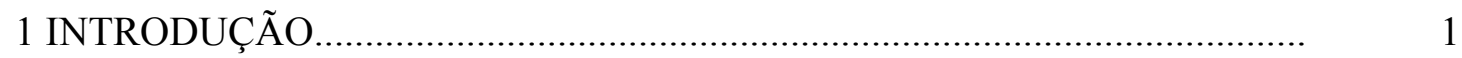

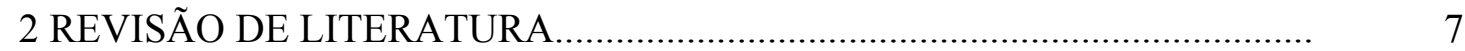

3 DETERMINAÇÃO EXPRESSÃO DO BANCO DE SEMENTES AUTÓCTONE EM DIFERENTES SITUAÇÕES AMBIENTAIS, VISANDO A DEFINIÇÃO DE METODOLOGIAS DIFERENCIADAS DE RESTAURAÇÃO …................................................................................... 15

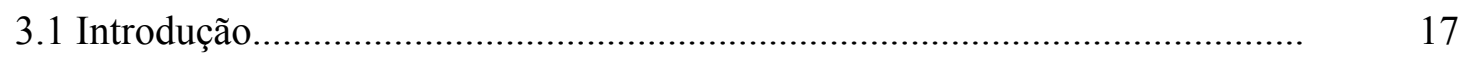

3.2 Material e Métodos............................................................................. 20

3.3 Resultados e Discussão......................................................................... $\quad 35$

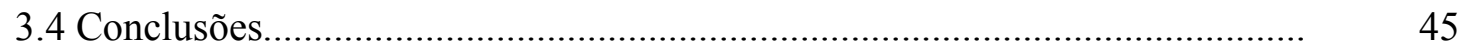

4 O USO DO BANCO DE SEMENTES ALÓCTONE COMO METODOLOGIA DE RECUPERAÇÃO DE ÁREAS DEGRADADAS............ 48

4.1 Introdução.................................................................................................. 50

4.2 Material e Métodos................................................................................... 53

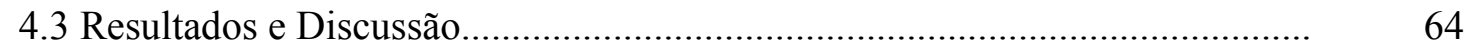

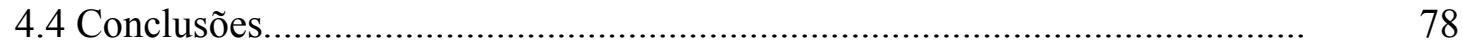


5 RESGATE DE INDIVÍDUOS ARBÓREOS REGENERANTES EM ÁREAS DE DESMATAMENTO, COMO ESTRATÉGIA COMPLEMENTAR DE PRODUÇÃO DE MUDAS DE ESPÉCIES NATIVAS COM DIVERSIDADE

5.1 Introdução......................................................................................... 82

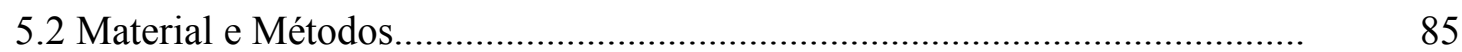

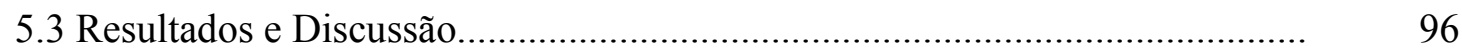

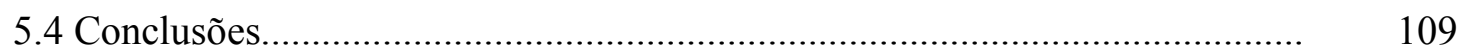

6 COMBINAÇÃO DAS ESPÉCIES EM GRUPOS DE PREENCHIMENTO E DIVERSIDADE, COMO METODOLOGIA DE RESTAURAÇÃO FLORESTAL NATIVA

6.1 Introdução

6.2 Material e Métodos.

6.3 Resultados e Discussão

6.4 Conclusões.

7 RESTAURAÇÃO FLORESTAL DA FAZENDA INTERMONTES: MONITORAMENTO DA EVOLUÇÃO DA PAISAGEM ….............................. 150

7.1 Introdução

7.2 Material e Métodos.

7.3 Resultados e Discussão. 164

7.4 Conclusões. 195

8 CONCLUSÕES GERAIS............................................................................. 197

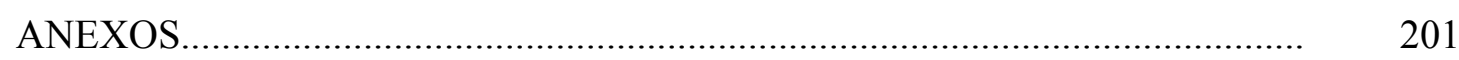

REFERÊNCIAS BIBLIOGRÁFICAS.......................................................... 205 


\title{
BANCO DE SEMENTES AUTÓCTONE E ALÓCTONE, RESGATE DE PLANTAS E PLANTIO DE VEGETAÇÃO NATIVA NA FAZENDA INTERMONTES, MUNICÍPIO DE RIBEIRÃO GRANDE, SP
}

\author{
Autor: ANDRÉ GUSTAVO NAVE \\ Orientador: Prof. Dr. RICARDO RIBEIRO RODRIGUES
}

\section{RESUMO}

O acúmulo significativo de conhecimento sobre a ecologia de restauração nos últimos anos tem conduzido a mudanças na orientação dos programas de manejo e restauração florestal. A escolha ou criação de um modelo de restauração é um processo em constante aprimoramento, exigindo a necessidade de estudos que não apenas diminuam os custos envolvidos, mas também, que garantam a efetividade do objetivo proposto. Neste sentido, este trabalho testa novas metodologias de restauração visando a obtenção de informações técnicas sobre: A) a expressão do banco de sementes autóctone e alóctone na restauração florestal de diferentes situações de degradação antrópica.; B) o resgate de plântulas e indivíduos de espécies arbustivo-arbóreas regenerantes; C) a eficiência de um modelo de plantio que utiliza conceitos de Preenchimento e Diversidade e; D) a evolução da paisagem. Para análise dos bancos de sementes autóctone e alóctone foram feitos levantamentos da densidade e das espécies 
arbustivo-arbóreas regeneradas. No resgate de indivíduos de espécies arbustivo-arbóreas regenerantes, as plântulas e indivíduos jovens foram resgatadas em uma floresta e levadas para adapatação em viveiro, onde tiveram seus indivíduos e espécies contabilizados em termos de densidade e sobrevivência. No modelo de plantio estudado, as espécies foram reunidas em grupos de Preenchimento e Diversidade e tiveram a cobertura de copa de cada indivíduo quantificada. A evolução da paisagem foi realizada através de fotointerpretação e principalmente checagem de campo periódica. Os principais resultados dessas metodologias foram: A) As situações identificadas na Fazenda Intermontes apresentaram diferentes expressões de regeneração natural em função do número de indivíduos germinados banco de sementes autóctone. $\mathrm{O}$ aproveitamento dessa expressão poderá ser realizado através de metodologias diferenciadas de restauração para cada situação estudada: B) No estudo do Banco de sementes alóctone, a densidade dos indivíduos germinados se foi de 409.334 indivíduos/ha, revelando a possibilidade de uso no programa de restauração. Os indivíduos arbóreos apresentaram na área adubada um acréscimo de 137,3 \% em sua altura média em relação aos indivíduos da área não adubada. C) No resgate de plântulas e indivíduos de espécies arbustivo-arbóreas regenerantes, a densidade dos indivíduos foi muito próxima para as duas épocas do ano, sendo 38.700 ind./ha e 37.900 ind./ha, mas com uma diferença significante para os indivíduos sobreviventes que apresentaram 16.500 ind./ha e 26.600 ind./ha para os meses de julho e dezembro de 2002, respectivamente. A técnica de resgate utilizada se mostrou viável uma vez que foi possível alcançar até $70,9 \%$ de sobrevivência para os indivíduos resgatados; D) No estudo sobre o modelo de plantio foram amostrados 143 espécies, demonstrando que a função do grupo da diversidade vem sendo mantida e aumentando as chances de efetivação dos processos de sucessão. Os resultados mostraram que o grupo de Preenchimento apresentou-se com uma porcentagem de cobertura significativamente maior que a do grupo de Diversidade, sendo $73,6 \%$ e $83,3 \%$ para 1,5 e 2,5 anos respectivamente. 


\title{
AUTOCHTHONOUS AND ALLOCHTHONOUS SEED BANK, SEEDLING RESCUE AND NATIVE VEGETATION PLANTING AT INTERMONTES FARM, RIBEIRÃO GRANDE-SP- BRAZIL
}

\author{
Author: ANDRÉ GUSTAVO NAVE \\ Adviser: Prof. Dr. RICARDO RIBEIRO RODRIGUES
}

\section{SUMMARY}

Significant accumulation of know-how about restoration ecology has been changing forest restoration management programs' trends during the last years. Choosing or elaborating a restoration model is a process that requires constant improvement and ecological studies that not only reduces the costs involved but also warrants the achievement of the aimed proposal. This study explores new restoration methodologies, searching for technical information about: A) autochthonous and allochthonous seed bank expression on forest restoration at different situations degraded by anthropogenic disturbances; B) seedlings and woody growing individuals rescue; C) efficiency of a planting model based on fulfillment and diversity concept; D) landscape development. The autochthonous and allochthonous seed bank were analyzed through regenerating woody species and density scouting. For the rescue of regenerating woody species, seedling and young individuals were taken from a forest and transferred to a plant nursery for adjustment, where number and species were counted regarding density 
and survival. In this studied planting model, species were organized and gathered into a fulfillment or diversity group, and each individual had its crown area quantified. Landscape development was analyzed by photointerpretation and specially by periodical field checking. Results from these methodologies showed that: A) Identified degraded situations at Intermontes farm displayed distinguished natural regeneration expression, influenced by the number of germinated seeds of the autochthonous seed bank. Advantage can be taken from these different outcomes by using distinct restoration methodologies for each studied situation. B) For the autochthonous seed bank study, germinated seed density was 409,334 ind./ha, indicating its potential role on restoration programs. Woody individuals at fertilized sites had a medium height enhancement of $137,7 \%$ when compared to those at non fertilized sites. C) For seedlings and woody growing individuals rescue, individual density was similar for both seasons (38700ind./ha and 37900ind./ha) but significantly distinct for individual survivor, with values of 16500ind./ha for July and 2600ind./ha for December. Rescue technique turned out to be a viable possibility since it achieved survival of $70,9 \%$ for rescued individuals. D) This planting model study registered 143 species, indicating that the diversity group's role has been maintained and enhances the chance of successional process success. The fulfilling group had a significant higher percentage of crown area than the diversity group, with $73,6 \%$ and $83,3 \%$ for 1,5 and 2,5 years, respectively. 


\section{INTRODUÇÃO}

O aumento da preocupação social com o destino dos fragmentos florestais remanescentes é crescente, de modo que as atividades de produção sem um planejamento ambiental adequado e que tenham como conseqüência a degradação ambiental, estão fadadas a sanções cada vez mais restritivas não só no aspecto legal, mas também, na própria consolidação do mercado consumidor que está cada vez mais exigente (Barbosa, 2004; Rodrigues et al., 2003a, 2003b, 2003c; Lopes et al., 2004; Rodrigues et al., 2004b). Como exemplo disso temos a ISO-14000, o selo verde, o FSC e outros, que são certificações que exigem a adequação ecologicamente correta dos produtos e bens produzidos. A adequação às normas da ISO-14000 certamente transformará em regras a implantação de sistemas de gestão e auditorias ambientais nas empresas, propiciando a conservação dos recursos naturais e a recuperação de áreas degradadas (Barbosa, 2004).

Dentro desse contexto, este trabalho foi desenvolvido na Companhia de Cimento Ribeirão Grande (CCRG), instalada a $12,5 \mathrm{~km}$ ao sul do município de Ribeirão Grande, SP e $250 \mathrm{~km}$ da cidade de São Paulo. A empresa tem como atividade principal a mineração de metacalcários e argila para produção de cimento (Figura 1).

O empreendimento está localizado no final da Rodovia João Pereira dos Santos Filho (SP 181), nas proximidades de importantes unidades de conservação do Estado de São Paulo, como o Parque Estadual de Carlos Botelho, a Estação Ecológica de Xituê, o Parque Estadual de Intervales e a APA da Serra do Mar, as quais representam um dos principais acervos de biodiversidade do Estado de São Paulo, inclusive por possuir características da zona de transição da Mata Atlântica para Floresta Estacional Semidecidual. 


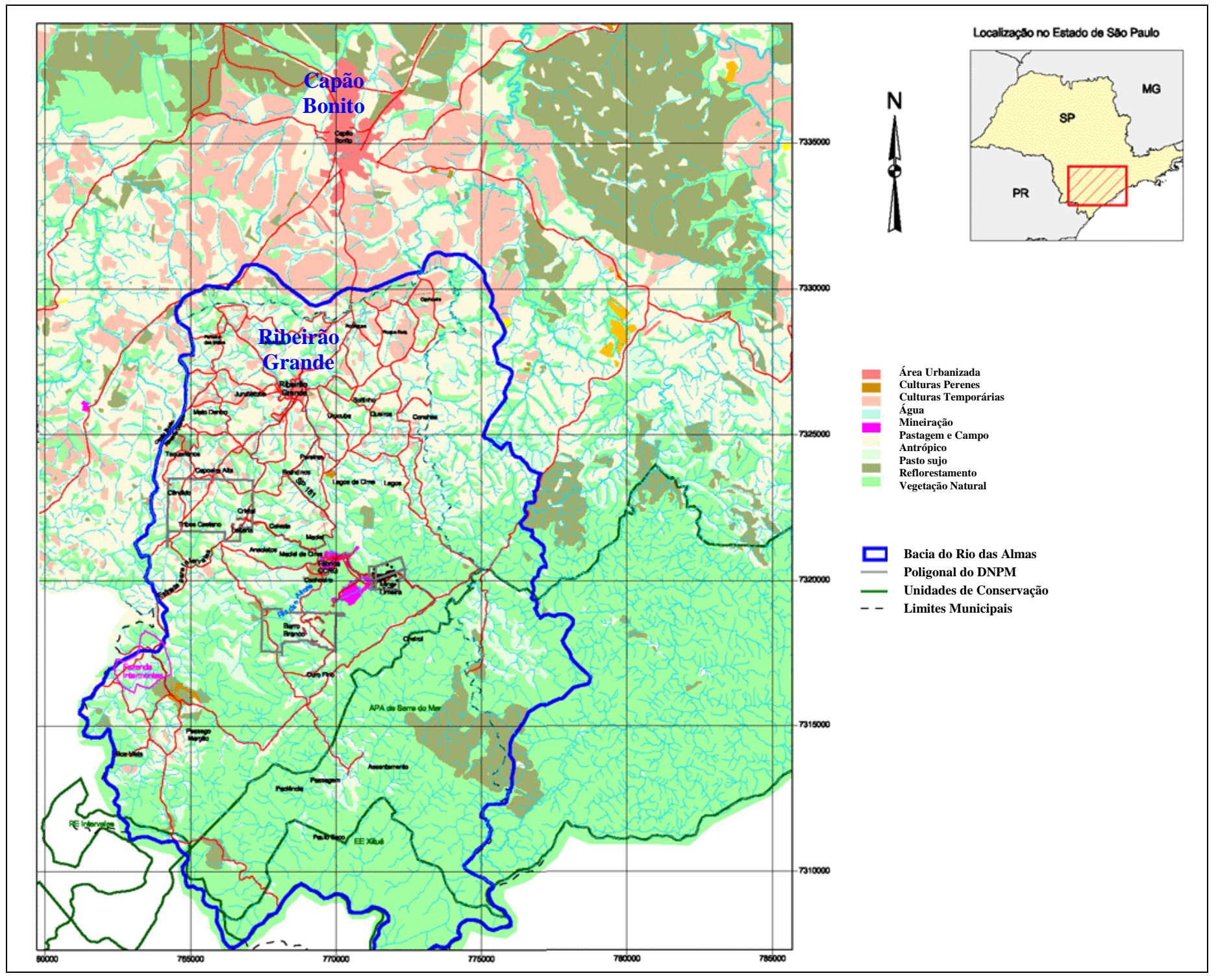

Figura 1 - Localização da Região do município de Ribeirão Grande no Estado de São Paulo 
Em 1996, a CCRG ganhou os direitos de lavra da mina Limeira e tornou-se proprietária da fábrica de cimento que já operava desde de 1976 pelo grupo João Santos (Figura 2). Naquele momento, ainda sem aprovação do plano de recuperação de áreas degradadas (PRAD) da mina Limeira pela Secretaria do Meio Ambiente (SMA), a fábrica dependia de compra de calcário da mina Sumidouro, pertencente à Companhia Brasileira de Equipamentos (CBE) (CCRG, 2003).

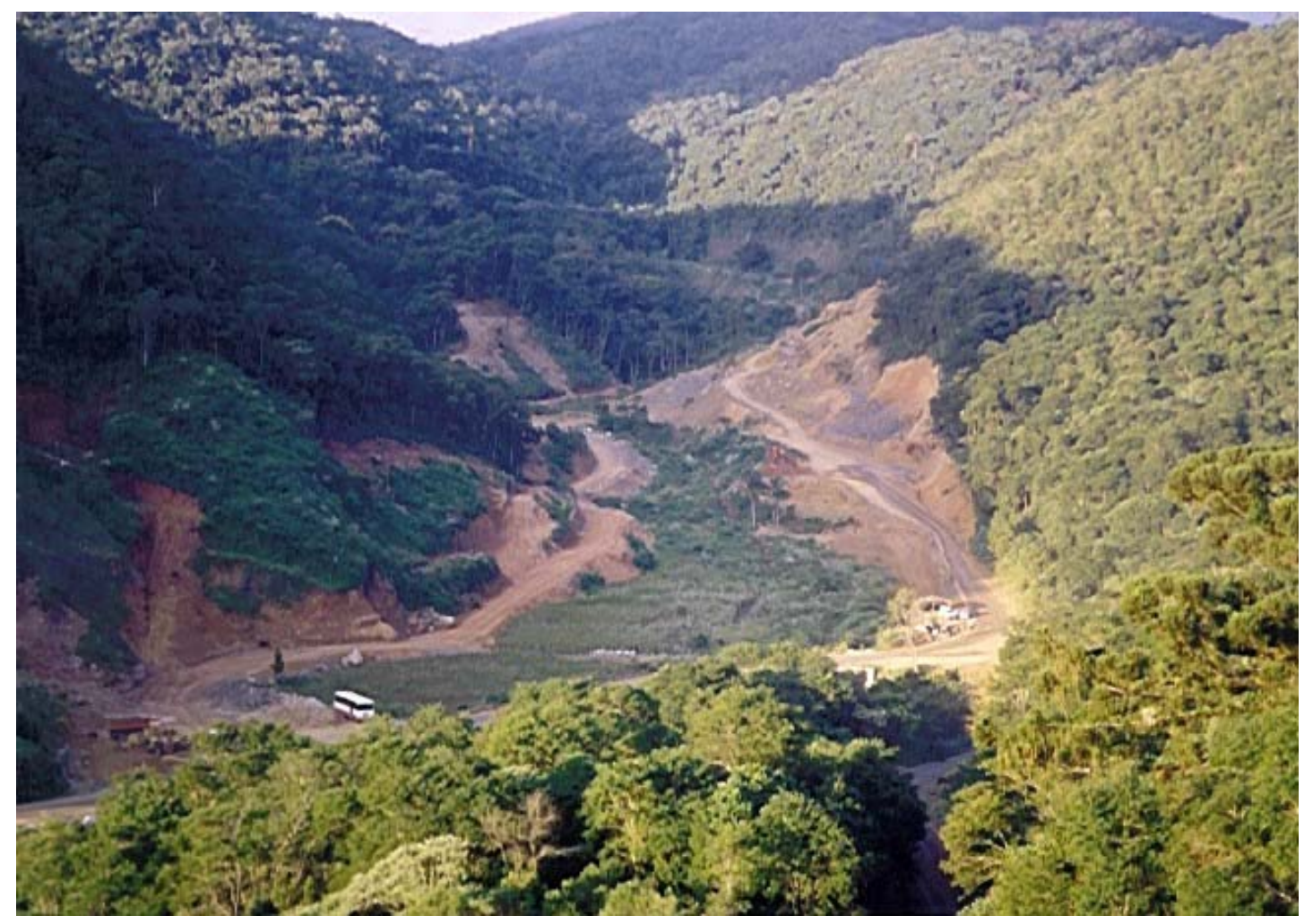

Figura 2 - Vista geral da Mina Limeira em 2001, com o início das atividades minerarias, CCRG, município de Ribeirão Grande, SP

Com obtenção da licença de funcionamento parcial emitida pela CETESB em 23/02/2001 e autorização de corte da vegetação nativa, emitida pelo DEPRN em 08/02/2001, o LERF/ESALQ (Laboratório de Ecologia e Restauração Florestal) foi convidado pela CCRG em 20/03/2001, para participar da elaboração e execução de medidas mitigadoras e compensatórias para os danos ambientais oriundos da mineração 
do calcário na mina Limeira, que envolve a supressão de 67,7 hectares de floresta em várias etapas consecutivas (CCRG, 2003).

Diante da oportunidade de estudo sobre o aproveitamento de propágulos que seriam suprimidos com o corte da vegetação florestal na mina Limeira, o LERF propôs o resgate do banco de sementes alóctone e do banco de plântulas e indivíduos jovens regenerantes como algumas das medidas mitigadoras do impacto gerado pelo empreendimento.

Além dessas medidas mitigadoras, a CCRG tinha como medida compensatória, a restauração ecológica de 164,5 ha de floresta na Fazenda Intermontes, também localizada no município de Ribeirão Grande, SP, a 12 Km da Mina Limeira (Figura 3).

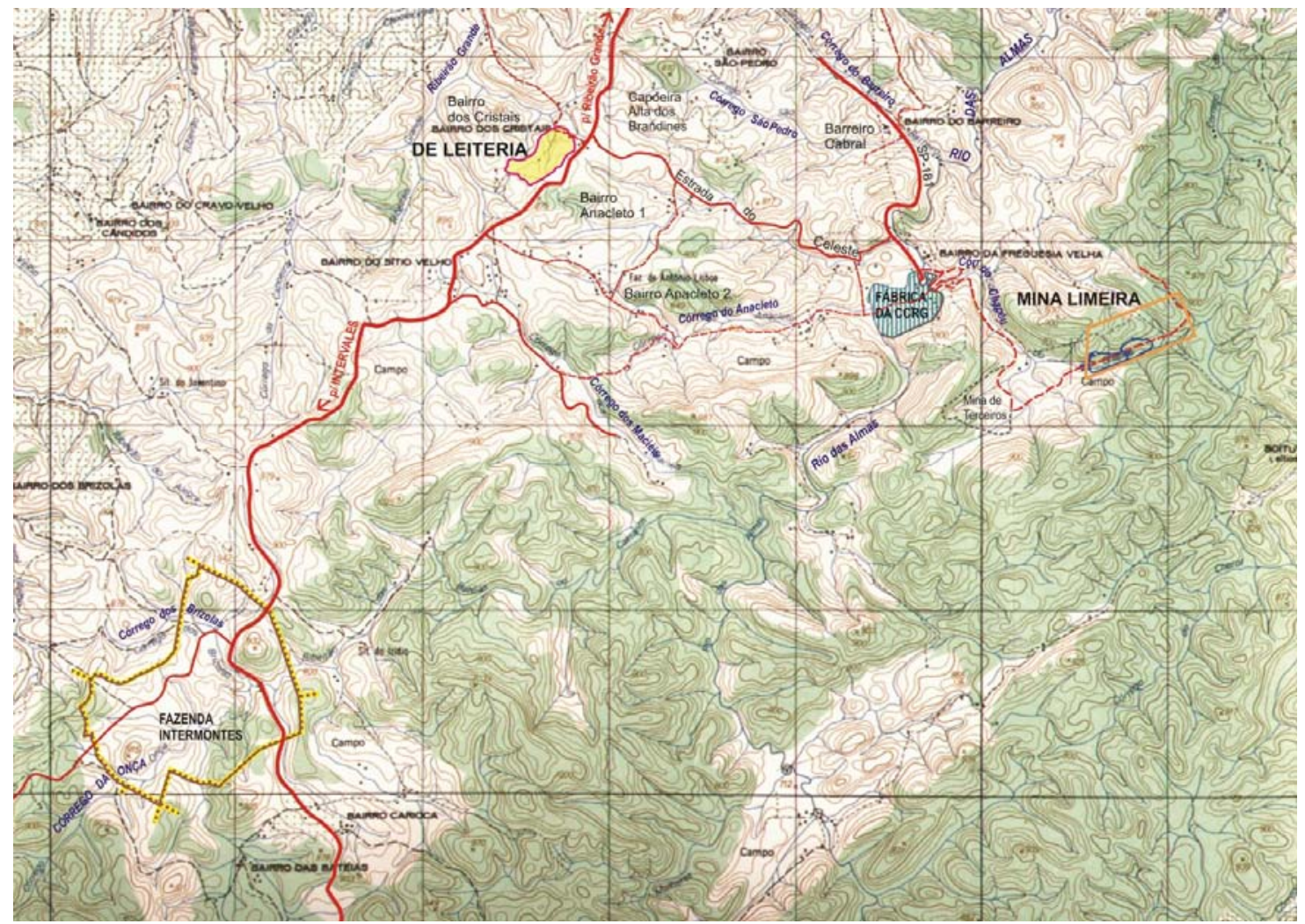

Figura 3 - Croqui de localização com a localização da Mina Limeira (área de origem do banco de sementes alóctone) e Fazenda Intermontes (área de depósito do banco de sementes), pertencentes à CCRG, município de Ribeirão Grande, SP 
A Fazenda recebeu inicialmente um estudo da expressão do banco de sementes autóctone para a restauração de áreas degradadas, definindo as possíveis metodologias de restauração que poderiam ser testadas nas diferentes situações ambientais da propriedade. Entre as metodologias de restauração recomendadas para a restauração das diferentes unidades da paisagem na Fazenda Intermontes, algumas se concentraram no reconhecimento, indução do potencial de regeneração natural da própria unidade e outras no aporte de propágulos (sementes, plântulas e mudas) oriundos de outras áreas, inclusive da própria floresta sobre a mina Limeira, que seria suprimida para exploração minerária.

Todas essas atividades de restauração desenvolvidos na mina Limeira e Fazenda Intermontes da CCRG, com diferentes metodologias de restauração, deram origem a esse trabalho que tem como objetivo principal, desenvolver novas tecnologias e subsidiar as futuras atividades de restauração florestal.

As metodologias de restauração testadas na Fazenda Intermontes buscaram alternativas para melhorar sua eficiência através de propostas inovadoras de restauração, tentando garantir a restauração dos processos ecológicos e usando procedimento mais próximos possíveis da dinâmica florestal, sempre atento ao custo de implantação. Em função disso, foram determinados os seguintes objetivos gerais desse trabalho:

- Conhecer a expressão do banco de sementes autóctone de diferentes situações de degradação antrópica, identificados através do zoneamento ambiental da Fazenda Intermontes;

- Conhecer a expressão do banco de sementes alóctone, oriundo da Mina Limeira, na restauração da Fazenda Intermontes;

- Obter informações técnicas sobre resgate de plântulas e indivíduos de espécies arbustivo-arbóreas regenerantes, que viabilize o uso dessa prática como estratégia complementar de resgate da diversidade vegetal em projetos de restauração ecológica; 
- Analisar a eficiência do modelo de plantio utilizado pelo Laboratório de Ecologia e Restauração Florestal (LERF/ESALQ - USP) e a possibilidade de melhoria do modelo de restauração utilizado;

- Promover a restauração florestal e acompanhar a evolução das várias unidades da paisagem da Fazenda Intermontes no município de Ribeirão Grande, SP. 


\section{REVISÃO DE LITERATURA}

A acelerada degradação das formações florestais do Estado de São Paulo nas últimas décadas já foi mostrada por diversos autores, dos quais destacamos os trabalhos de Hueck (1972), Troppmair (1969), Victor (1975), Reichmann Neto (1978), Consema (1985) e Kronka et al. (1993). A expansão da fronteira agrícola, associada mais recentemente ao crescimento urbano, foram os principais responsáveis por essa degradação (Nave, 1999; Rodrigues \& Gandolfi, 2004).

A devastação florestal chegou até mesmo em áreas de difícil acesso, tornando-se raros os fragmentos remanescentes ainda bem conservados (Hueck, 1972; Rodrigues \& Gandolfi, 2004; Rozza, 1997; Nave, 1999). Essas modificações ambientais, com conseqüente degradação das formações naturais do Estado de São Paulo, foram de tamanha proporção, que atualmente restam apenas pequenos fragmentos de vegetação natural. Segundo o Inventário Florestal do Estado de São Paulo (Kronka et al., 1993), o estado possui cerca de 33.307.744 ha de florestas naturais, ou seja, 13,4\% de seu território. Essas florestas se encontram geralmente bem fragemntadas, apresentando um avançado estágio de perturbação e ainda sofrendo interferências antrópicas de diferentes naturezas como fogo, extrativismo seletivo, uso para pastagem, etc.

Em todo o Estado de São Paulo, há mais de um milhão de hectares nas margens dos cursos d'água e represas sem a proteção de cobertura vegetal (Fundação Florestal, 2004). A importância da recuperação desses recursos naturais é inquestionável, em função dos seus vários benefícios como a conservação da biodiversidade, a formação de corredores ecológicos, a proteção aos recursos hídricos e edáficos, a manutenção de características climáticas, entre outros (Rodrigues \& Nave, 2004; Barbosa, 2004; Kageyama, 2001). 
Motivada por um maior nível de concientização da sociedade e de mudanças no enfoque da silvicutura no Brasil, a pesquisa voltada para o desenvolvimento de sistemas de restauração tem avançado consideravelmente nos últimos anos (Engel et. al., 2001). $\mathrm{O}$ acúmulo significativo de conhecimento sobre as florestas tropicais e sobre os processos envolvidos na sua dinâmica (tanto de áreas remanescentes preservadas, como em diferentes graus e tipos de degradação), tem conduzido a uma significativa mudança na orientação dos programas de manejo e restauração florestal, que deixaram de ser mera aplicação de práticas agronômicas ou silviculturais, para assumir a difícil tarefa de reconstrução das complexas interações da comunidade. Entre os principais conceitos que mudaram os sistemas de restauração florestal, podemos citar: o aumento da diversidade de espécies; o aumento da diversidade genética; a sucessão ecológica e; a dinâmica do ecossistema (Rodrigues \& Gandolfi, 2004; Kageyama et al., 2003).

Nesse contexto, o avanço mais significativo para os projetos de restauração ecológica foi o início de um processo de aprendizagem, deixando de plantar um amontoado de indivíduos arbóreos, geralmente em um único modelo, e passando a considerar o potencial de auto-recuperação dessas áreas. Esse potencial é definido de forma diferencial para cada unidade da paisagem, de acordo com o histórico de degradação, o uso atual e as características do entorno dessas unidades (Rodrigues et al., 2003a, 2003b, 2003c; Lopes et al., 2004; Engel \& Parrotta, 2003; Rodrigues et al., 2004b). Com isso, atualmente existe uma preocupação maior com a reativação e restauração dos processos ecológicos nessas áreas, proporcionando maiores chances de sucesso na perpetuação das áreas restauradas. Como conseqüência temos a redução de custos, possibilitando a aplicabilidade dessas práticas em pequena e larga escala em benefício de toda a sociedade (Rodrigues \& Gandolfi, 2004; Rodrigues et al., 2003a; Engel \& Parrotta, 2003).

Deste modo, as metodologias de restauração ecológica testadas nesse trabalho se pautam em duas preocupações principais: a primeira é a de estabelecer as ações de recuperação, sempre atentando para o potencial ainda existente de auto-recuperação dessas áreas, definido pelas características atuais da área, do entorno e pelo seu histórico de degradação; a segunda preocupação é que essas iniciativas sejam feitas sempre com 
elevada diversidade, aumentando as chances de perpetuação da área restaurada, através do restabelecimento dos vários processos ecológicos, responsáveis pela manutenção da dinâmica florestal.

Portanto, o termo "restauração" usado neste trabalho, não possui o significado de recuperação integral dos ecossistemas naturais, mais sim, de recriar comunidades naturais onde os processos ecológicos mantenedores da biodiversidade tenham sido desencadeados (Rodrigues \& Gandolfi, 2004; Rodrigues et al., 2003a; Engel \& Parrotta, 2003). Assim, a "restauração" foi definida como qualquer ação que permita a recuperação da integridade ecológica dos ecossistemas, considerando um "mínimo" de biodiversidade e de variabilidade na estrutura e no funcionamento dos processos ecológicos e incorporando seus valores ecológicos, econômicos e sociais ("Society for Ecological Restoration").

\subsection{Os Paradigmas Ecológicos e a Restauração de Áreas Degradadas}

Apesar das primeiras iniciativas de reflorestamentos terem se iniciado desde o século XIX no Brasil (Cézar \& Oliveira, 1992), somente na década de 1980, com o desenvolvimento da ecologia de florestas naturais e a consolidação da ecologia da restauração como ciência, os trabalhos de restauração passaram a incorporar os conceitos e paradigmas da ecologia florestal para a sustentação conceitual das metodologias de restauração (Rodrigues \& Gandolfi, 2004; Engel \& Parrotta, 2003).

Nessa época, os trabalhos de cunho científico eram baseados no Paradigma Clássico da Ecologia, também chamado de "Paradigma do Equilíbrio", que enfatizava a existência de um ponto de equilíbrio nos ecossistemas (Pickettet al., 1992; Pickett \& Ostfeld, 1994). Os sistemas naturais eram considerados fechados e auto-reguláveis (Pickettet al., 1992; Pickett \& Ostfeld, 1994) e a sucessão ocorreria através da convergência de fases para atingir um clímax único, o qual comandaria a sucessão (Clements, 1916). Nesses sistemas, os ambientes perturbados oscilavam, mas acabavam retornando para condição inicial, próximo do clímax único. As perturbações naturais 
eram tratadas como eventos excepcionais (Clements, 1928) e o homem excluído como potencial regulador desses processos.

No paradigma clássico, os processos de sucessão ocorriam de forma ordenada, direcionada e previsível, controlada pela comunidade e principalmente convergindo para um clímax regional único dentro de um ecossistema estabilizado, com propriedades homeostáticas (Clements, 1916, 1928; Odum, 1969). Nesse conceito, a capacidade suporte de uma população seria fixa e constante.

Assim, após algum tipo de perturbação, se os sistemas naturais fossem isolados, eles se auto-regulariam depois de algum tempo (Pickettet al., 1992). Desconsiderava-se o papel dos habitantes tradicionais na determinação das características das áreas que se pretendia conservar (Pickett \& Ostfeld, 1994). As populações humanas e suas atividades não eram consideradas parte natural do sistema e por esse motivo, era necessário isolar as áreas naturais do próprio homem (Pickettet al., 1992), tanto para conservação como para geração de conhecimento teórico.

Assim, os trabalhos de levantamentos florísticos e fitossociológicos eram realizados em florestas mais preservadas possível (Pickett \& Ostfeld, 1994), servindo de modelo ideal para a definição metodológica dos projetos de restauração. Em função disso, os modelos de plantio tentavam reproduzir o clímax idealizado nas florestas preservadas, aumentando o custo de implantação.

Nesse contexto, durante algum tempo o termo "restauração" foi utilizado no seu sentido restrito, significando o retorno ao estado original do ecossistema com todas as suas características (Engel \& Parrotta; 2003). Com isso, foram criados vários modelos de restauração que buscavam, pelo menos teoricamente, a implantação de um modelo clímax. Isso só poderia ser realizado através do plantio de mudas, onde era possível programar quais e quantas espécies iriam ser plantadas e o número de indivíduos de cada uma (Rodrigues \& Gandolfi, 2004). Dessa forma, pretendia-se copiar um sistema clímax, acreditando que este seria o ponto de equilíbrio da floresta madura, o qual deveria ser mantido a qualquer custo. 


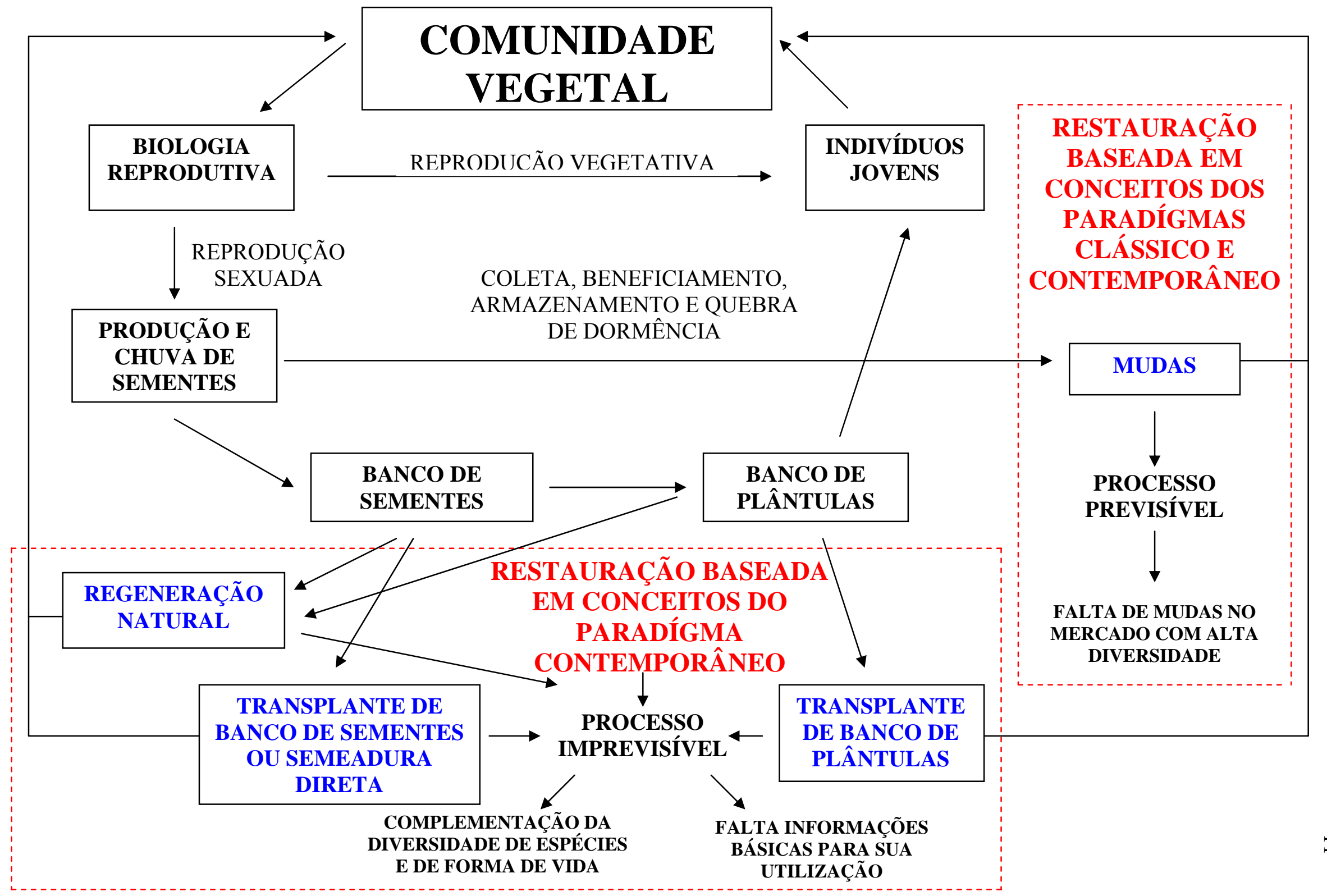

Figura 4 - Possibilidades de restauração usando várias formas de propágulos e conceitos ecológicos 
Dentro desse contexto, a partir da década de 1980 e parte da década de 1990, a pesquisa com restauração de áreas degradadas se restringiu, principalmente, em testar modelos de combinação de espécies e de diferentes grupos sucessionais no plantio de mudas (Rodrigues et al., 1992; Macedo et al., 1993; Crestana et al., 1993; Durigan \& Nogueira, 1990; Barbosa, 2004; entre outros).

Assim, a indução e condução da regeneração natural, a partir do banco de sementes e/ou de indivíduos jovens regenerantes e a semeadura direta no campo, como possíveis metodologias de restauração, acabaram não sendo exploradas pela pesquisa nesse período. Nessas metodologias não era possível o pré-estabelecimento das espécies e do número de indivíduos idealizado para o local a ser restaurado, dentro do conceito de restauração do clímax único para aquela determinada condição (Figura 4).

Com o surgimento do Paradigma Contemporâneo, também conhecido como Paradigma do não equilíbrio (Pickettet al., 1992) - A Natureza em Fluxo -, é aceita a teoria de que as mudanças sucessionais da vegetação podem ocorrer seguindo múltiplas trajetórias (Pickettet al., 1992), não existindo uma convergência nas mudanças do sistema para chegar a um "ponto clímax ideal". Nas comunidades naturais, o clímax está em constante fluxo, portanto, os sistemas naturais teriam muitos "clímaces" e muitos "caminhos" para chegar a esses clímaces.

Distúrbios naturais ou antrópicos, tais como o fogo, as cheias, tempestades, etc., podem determinar e portanto, alterar a composição e a estrutura horizontal e vertical das comunidades, das paisagens (Pickett \& Thompson, 1978), assim como, o tamanho, a idade e a estrutura genética das populações.

No Paradigma Contemporâneo, os sistemas naturais são considerados abertos, sujeitos as influências de fatores externos, onde o equilíbrio é relativo numa escala de tempo. As perturbações naturais são consideradas partes comuns dos sistemas, alterando os processos de sucessão, o qual não é mais considerado determinístico, mais sim estocástico.

Dependendo dos eventos históricos, são formadas rotas alternativas num determinado sistema para que este alcance um clímax (Fiedler et al., 1997). Da mesma forma, as ações humanas, dependendo do grau de intervenção, podem ser consideradas 
como um fator ecológico natural. As interações entre os padrões de dispersão e o histórico de interferências determinam trajetórias sucessionais com características próprias (Bazzaz, 1996). É importante relatar que o Paradigma Contemporâneo enfatiza os processos ecológicos dentro de um contexto dinâmico de um ecossistema e não de um ponto final estável (Vitousek \& White ${ }^{1}$, citado por Pickett et al., 1992).

Dessa forma, no final da década de 1990, os conceitos do Paradigma Contemporâneo foram gradualmente sendo incorporados nas metodologias de restauração, abrindo um novo caminho para estudos que desejam recriar comunidades naturais, incluindo uma relação saudável entre o homem e a natureza (Rodrigues \& Gandolfi, 2004; Engel \& Parrotta, 2003).

A incorporação desses conceitos nos trabalhos de restauração ecológica atualmente está ocasionando importantes mudanças metodológicas nas atividades de restauração. Uma delas é a utilização de propágulos muitas vezes disponíveis no próprio local a ser restaurado, nas suas mais diversas formas e origens, ou mesmo de propágulos trazidos de outros ambientes naturais ou mesmo antropizados. Vale ressaltar que, algumas metodologias que estão ganhando força atualmente, já foram usadas instintivamente no século XIX, em iniciativas como o reflorestamento da Floresta Nacional da Tijuca, no Rio de Janeiro, através do aproveitamento da regeneração natural que aparecia nas entrelinhas dos plantios e também do transplante de mudas na área de recuperação, trazidas de fragmentos florestais remanescentes no entorno (Cézar \& Oliveira, 1992).

Dentro deste contexto e de acordo com o Paradigma Contemporâneo, são necessárias três condições básicas para que ocorram os processos de sucessão em uma área a ser restaurada: a) Disponibilidade de local adequado; b) Disponibilidade de diferentes espécies; c) Disponibilidade de diferentes performances entre as espécies (Pickett et al., 1987).

É neste sentido que este trabalho estuda algumas metodologias de restauração, incorporando, principalmente, a idéia de restauração das funções do ambiente e dos

\footnotetext{
${ }^{1}$ VITOUSEK, P.M.; WHITE, P.S. 1981. Process studies in succession. In Forest succeccion: Concepts and application, ed. D.C. West, H.H. Shugart, and D.B. Botkin, 267-75. New York: Springer-Verlag.
} 
processos ecológicos envolvidos, aumentando as chances de sustentabilidade e perpetuação do sistema, independente do clímax final alcançado (Pickett et al., 1992).

A incorporação desses novos conceitos nas metodologias de restauração permite ainda a inclusão de outras importantes formas de vida, além das arbóreas como arbustos, herbáceas, lianas não agressivas, epífitas, as quais, eram simplesmente ignoradas nas metodologias convencionais (Rodrigues et al., 2003a).

Assim, as metodologias de restauração que envolvem o aproveitamento da regeneração natural, através do banco de sementes e de indivíduos jovens autóctone e/ou alóctone, de semeadura direta ou mesmo do plantio de mudas em modelos sucessionais não preocupados com um clímax único, mas sim, a restauração dos processos ecológicos, são atualmente os caminhos mais promissores para alcançar os objetivos propostos. 


\section{DETERMINAÇÃO DA EXPRESSÃO DO BANCO DE SEMENTES AUTÓCTONE, EM DIFERENTES SITUAÇÕES AMBIENTAIS, VISANDO A DEFINIÇÃO DE METODOLOGIAS DIFERENCIADAS DE RESTAURAÇÃO}

Resumo

O conhecimento sobre a composição e quantificação do banco de sementes autóctone, principalmente voltado para espécies arbustivo-arbóreas, em situações de restauração florestal, possibilita a definição de técnicas diferenciadas de restauração, sendo de grande importância para definição dos métodos de recuperação. Este trabalho apresenta uma avaliação do banco de sementes de cinco situações de restauração identificadas através do Zoneamento Ambiental da Fazenda Intermontes e as correlações existentes com os indicadores de campo. Através da fotointerpretação e checagem de campo, a Fazenda Intermontes teve suas áreas divididas em 6 principais situações: a) Pasto sem regeneração natural; b) Pasto com regeneração arbustiva; c) Pasto com regeneração arbórea; d) Capoeira; e) Floresta e; f) Solo sem vegetação. O solo contendo o banco de sementes autóctone foi coletado em cinco das situações ambientais identificadas. As situações identificadas tiveram 16 amostras retiradas de parcelas com dimensões de 50 X $50 \mathrm{~cm}$, totalizando $0,25 \mathrm{~m}^{2}$ e $3 \mathrm{~cm}$ de profundidade. As amostras foram levadas para o Laboratório de Ecologia e Restauração Florestal (LERF) da ESALQ/USP, onde foram colocadas para germinar em canteiros de forma casualizada. Os canteiros foram montados em parcelas de 1,0 $\mathrm{m}$ de comprimento e 0,25 $\mathrm{m}$ de largura, ficando expostos ao tempo. As parcelas foram irrigadas 2 vezes ao dia, no início da manhã e final da tarde, exceto nos dias de chuva. As situações ambientais apresentaram 
diferentes expressões de regeneração natural em função do número de indivíduos de espécies arbustivo-arbóreas germinados banco de sementes autóctone. A maior densidade de indivíduos de espécies arbustivo-arbóreas germinados foi da situação de floresta, que apresentou o número estimado de 690.000 indivíduos/ha. As outras situações de pasto com regeneração arbustiva, pasto com regeneração arbórea e capoeira apresentaram 42.500, 67.500 e 472.500 indivíduos/ha, respectivamente. As fisionomias de capoeira e floresta apresentaram as maiores riquezas em espécies, sendo 11 e 9 espécies arbustivo-arbóreas, respectivamente em cada uma delas. Do total de espécies encontradas, 2 foram classificadas como arbustivas. Todas as 11 espécies encontradas pertencem ao grupo ecológico das pioneiras. Os resultados da germinação do banco de sementes autóctone mostraram que presença de indivíduos de espécies arbustivoarbóreas regenerantes, na fisionomia da área a ser restaurada, está relacionada à presença de banco de sementes de mesma forma de vida no solo.

\section{Summary}

The information about autochthonous seed bank composition and quantity regarding forest restoration, mainly focused on woody species, makes possible the definition of distinct restoration techniques, being of great importance for restoration ecology. This study presents a seed bank evaluation in five different restoration situations, environmental zones of Intermontes farm and existent correlation within field indicators. Through photointerpretation and field checking, Intermontes farm had its area divided into 6 situations: a) pasture without natural regeneration; b) pasture with shrub regeneration; c) pasture with woody regeneration; d) "capoeira"; e) forest e; f) soil lacking vegetation. Soil was collected in five of those 6 identified situations, where 16 squared samples of $50 \times 50 \mathrm{~cm}\left(0,25 \mathrm{~m}^{2}\right)$ and $3 \mathrm{~cm}$ depth were taken. Samplings were brought to Forest Restoration and Ecology Laboratory (LERF) - ESALQ/USP, where they were set and left to germinate in flower-beds, in an occasional way. The flowerbeds were established in $1,0 \mathrm{~m} \times 0,25 \mathrm{~m}$ weather exposed plots. Plots were watered twice daily, in the morning and afternoon, except on rainy days. Environmental situations 
presented different natural regeneration expressions related to the number of germinated woody individuals on the autochthonous seed bank. The highest density of germinated woody seeds were observed under forest situation, which presented the estimated number of 690.000 ind. /ha. Shrubby regeneration, pasture with woody regeneration and "capoeira" situations resulted in 42.500, 67.500 e 472.500 ind. /ha respectively. "capoeira" and forest physionomy had the higher species richness, with 11 and 9 woody species for each of them respectively. From all the species found, two were identified as shrubs. All woody species were classified into the pioneers' ecological group. Autochthonous seed bank germination results linked the presence of woody species on a restored area to its presence in the seed bank.

\subsection{Introdução}

Os estudos sobre a possibilidade do manejo da regeneração natural, com objetivo da restauração de áreas degradadas, ainda são escassos, mas com grande potencial de incremento em função de seu baixo custo e de bons resultados em termos de diversidade e restauração dos processos ecológicos, quando comparados às florestas implantadas a partir de mudas (Crestana, 1993; Rodrigues \& Gandolfi, 2004; Durigan et al., 2003a, 2003b; Fundação Florestal, 2004).

As áreas degradadas, cujo histórico de perturbação não resultou no total extermínio de propágulos no solo, ou nas situações onde existe a possibilidade da chegada de propágulos da vegetação remanescentes do entorno, geralmente apresentam potencial de regeneração natural. Esses propágulos, se devidamente manejados, podem colaborar na restauração dessas áreas (Rodrigues \& Gandolfi, 2004). Apesar de limitados, as sementes disponíveis no banco, podem fornecer indicativos sobre a capacidade de regeneração natural de uma determinada área (Siqueira, 2002).

É freqüente a existência de áreas agrícolas ou pastagens que após abandono, foram reocupadas naturalmente por espécies nativas, oriundas do processo de sucessão ecológica. Isso ocorre principalmente em locais degradados inseridos numa matriz 
florestal relativamente bem conservada, com a presença de fragmentos naturais remanescentes no entorno ou mesmo em situações onde o histórico de degradação não foi tão intenso (Rodrigues et al., 2004a).

A expressão da regeneração natural varia de acordo com o tipo de formação florestal de origem, o histórico de degradação da área, a ocupação atual, a qualidade e a proximidade dos fragmentos florestais do entorno, entre outros. Essas diferenças são facilmente percebidas em áreas de cerrado, geralmente com grande potencial de regeneração natural, em função das características reprodutivas, muito particulares e heterogêneas, desses ecossistemas, podendo rebrotar inúmeras vezes, após perturbações como fogo e roçagem (Durigan et al., 2003a). A intensidade da regeneração natural também será diferenciada dependendo do sucesso conseguido na redução dos fatores de perturbação que atuam sobre uma determinada área (Crestana, 1993; Rodrigues \& Gandolfi, 2004; Fundação Florestal, 2004).

Em áreas antropizadas, o mosaico produzido na paisagem é muito heterogêneo, com diferentes situações ambientais as vezes muito próximas, dependendo das características regionais de uso e ocupação atual e histórica do solo e das características edáficas e de relevo. Cada situação do mosaico ambiental poderá apresentar potenciais diferenciados de regeneração natural, em função de suas características de uso histórico e atual e das características do entorno, definindo assim, a sua resiliência quando incorporado o componente temporal (Rodrigues \& Shepherd, 2001).

A resiliência pode ter relações diretas com o banco de sementes do solo, existência de remanescentes de espécies nativas com a chegada desses propágulos pela chuva de sementes, oriundos das áreas naturais do entorno. Assim, o estoque de sementes no banco é regulado por processos de entrada de sementes como dispersão e chuva de sementes e saída como morte natural; predação, doenças e germinação (Hyatt \& Casper, 2000).

Em pequenos trechos degradados, a identificação de áreas com possível potencial de regeneração natural, pode ser realizada diretamente no campo, através da observação de indícios de regeneração natural como, por exemplo, a presença de indivíduos regenerantes, a proximidade de fragmentos florestais e o histórico de uso do local, a 
ocupação atual e outros (Rodrigues \& Gandolfi, 2004; Rodrigues et al., 2004a). A presença de banco de sementes de espécies nativas capazes de restabelecer os processos de regeneração natural pode se expressar no local a ser restaurado, através da presença de alguns indivíduos regenerantes. Dessa forma, a ocorrência repetida destes indivíduos numa determinada área, principalmente indivíduos de espécies iniciais de sucessão, poderá indicar a presença de banco de sementes dessas espécies nessa área (Rodrigues \& Gandolfi, 2004). Esses indicadores devem ser usados durante a checagem de campo para elaboração do Zoneamento Ambiental (Rodrigues et al., 2004a).

Para grandes áreas, esta tarefa é realizada através do uso da fotointerpretação, sendo que essa atividade é procedida da checagem de campo para averiguação dos resultados obtidos e confirmação ou não da presença desses indivíduos regenerantes no campo. Essas atividades são definidas como "Zoneamento Ambiental" (Rodrigues et al., 2001; Rodrigues et al., 2003a, 2003b, 2003c; Lopes et al., 2004; Rodrigues et al., 2004a; Rodrigues et al., 2004b).

Nesse diagnóstico, são caracterizados o tipo de ocupação atual e principalmente as potencialidades de regeneração natural dessas áreas, de forma a permitir a definição de ações diferenciadas para cada uma das situações identificadas, visando desencadear e conduzir os processos naturais de restauração. Dentro desse contexto, o zoneamento ambiental vai permitir a particularização das ações de restauração e dentro dessas, o manejo do banco de sementes através da indução, a condução da regeneração natural e o uso no plantio de espécies atrativas da fauna, são algumas das possibilidades. Assim, parte da restauração poderá ser obtida a partir da regeneração natural, se esta for adequadamente induzida e conduzida em ações de manejo. Isso tem como conseqüência não só a redução dos custos da adequação ambiental, mas também, maior garantia de sucesso das ações adotadas (Rodrigues et al., 2003a, 2003b, 2003c; Lopes et al., 2004; Rodrigues et al., 2004b).

O conhecimento sobre a composição e quantificação do banco de sementes, principalmente referentes às espécies arbustivo-arbóreas, possibilita a definição de metodologias diferenciadas de restauração que considerem o aproveitamento dessas 
sementes no processo de restauração, sendo de grande importância para o sucesso do processo de recuperação.

É nesse sentido que esse trabalho apresenta uma avaliação do banco de sementes de cinco situações de restauração identificadas através do Zoneamento Ambiental da Fazenda Intermontes e as correlações existentes com os indicadores de campo.

Assim, o objetivo desse trabalho é conhecer a expressão do banco de sementes na restauração florestal de diferentes situações de degradação antrópica, identificados através do zoneamento ambiental da Fazenda Intermontes, considerando as seguintes perguntas: a) diferentes situações de degradação podem apresentar diferentes possibilidades de restauração em função das características do banco de sementes? b) qual a densidade de indivíduos e a riqueza de espécies regenerantes do banco de sementes autóctone na área de estudo? c) quais os grupos ecológicos predominantes entre as espécies germinadas do banco de sementes autóctone e de que maneira eles podem interferir nas metodologias de restauração? d) quais as situações identificadas na Fazenda Intermontes que são recomendadas para o uso do banco de sementes autóctone nos processos de restauração florestal? e) a presença de indivíduos regenerantes na fisionomia da área a ser restaurada, pode estar relacionada à presença de banco de sementes?

\subsection{Materiais e Métodos}

\subsection{1 Área de estudo}

Este trabalho foi desenvolvido na Companhia de Cimento Ribeirão Grande (CCRG), distante aproximadamente $12,5 \mathrm{~km}$ ao sul do município de Ribeirão Grande, SP e cerca de $250 \mathrm{~km}$ da cidade de São Paulo (Figura 1). A empresa tem como atividade mineraria a exploração de metacalcários e argila para produção de cimento. 


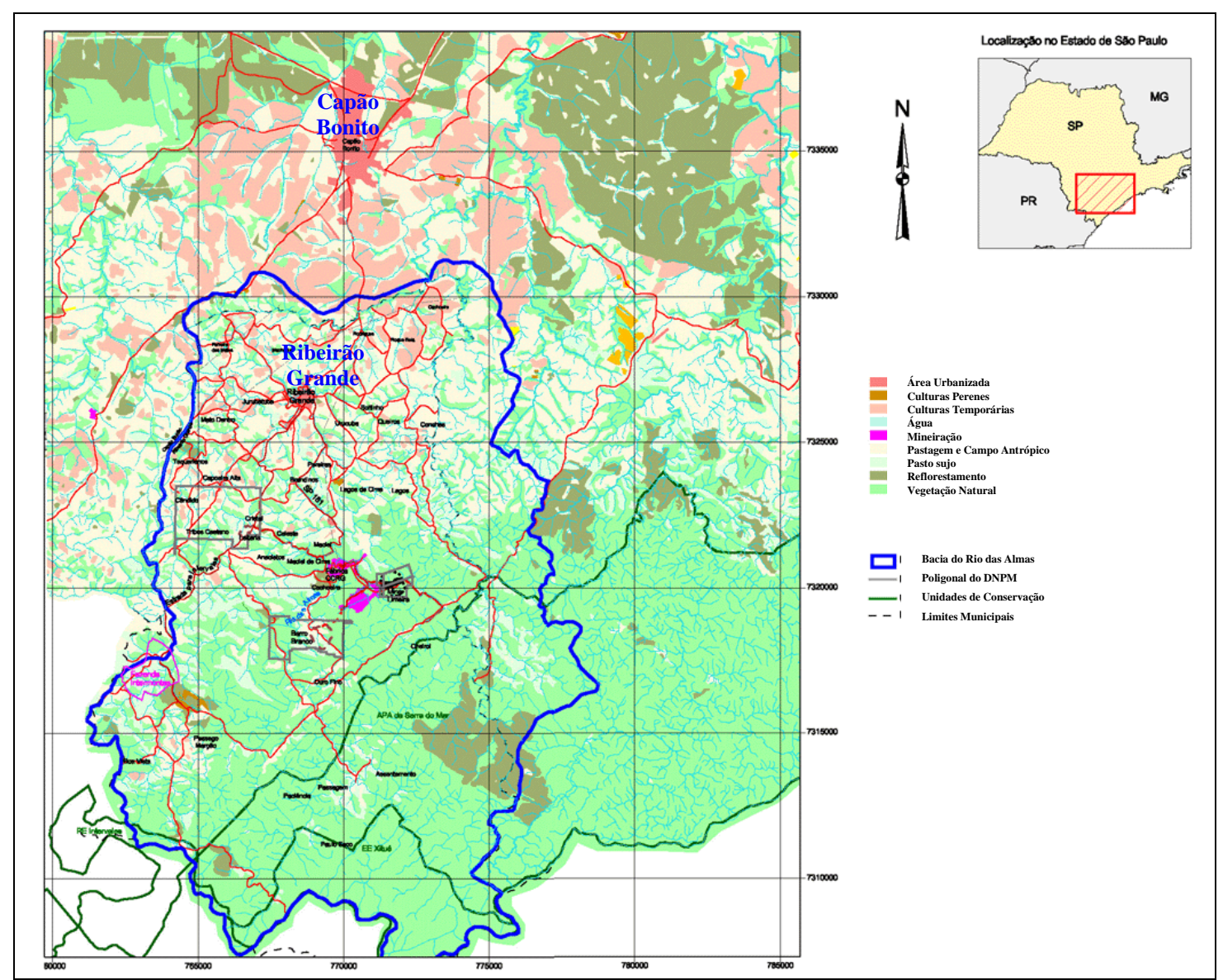

Figura 1 - Localização da Região do município de Ribeirão Grande no Estado de São Paulo

Com as medidas compensatórias geradas com o corte da vegetação na mina Limeira (autorizada pelo DEPRN em 08/02/2001), a CCRG definiu a restauração da Fazenda Intermontes como local para essas atividades. A Fazenda teve inicialmente um estudo do banco de sementes autóctone realizado pelo Laboratório de Ecologia e Restauração Florestal (LERF), o qual gerou este trabalho.

A Fazenda Intermontes possui 343,0 ha e está localizada na estrada que liga o município de Ribeirão Grande ao Parque Estadual de Intervales, distante aproximadamente $17 \mathrm{~km}$ ao sul do Município de Ribeirão Grande. Sua localização 
geográfica está inserida entre as coordenadas UTM 7.322.500 N; 762.750 L e 7.319.800 $\mathrm{N} ; 760.250 \mathrm{~L}$.

Da mesma forma que ocorreu em toda a região, a vegetação natural da Fazenda Intermontes apresenta trechos de floresta secundária explorada no passado pelo extrativismo seletivo de espécies madeireiras, produção de carvão e possível exploração de palmito (Guix, 1994; Reis; Reis, Ribeiro, 1994).

Atualmente estes trechos de floresta estão confinados em locais bastante íngremes e de difícil acesso, mas ainda bem estruturadas com árvores de grande porte e seus estratos bem definidos. Dentro deste contexto, as áreas identificadas na Fazenda com a situação de floresta, entraram no plano de restauração apenas com ações de isolamento e retirada de fatores de degradação, uma vez que, estas já se encontravam num estado relativamente avançado de conservação.

Muitas das áreas apresentavam-se como capoeiras, oriundas de trechos anteriormente desmatados, usados como pasto e posteriormente abandonados. Encontram-se ainda em determinados locais da Fazenda, ruínas de fornos usados na produção de carvão.

As áreas produtivas da Fazenda eram compostas apenas por pastos classificados neste trabalho em 3 situações diferenciadas: a) pasto sem regeneração natural, o qual apresentava-se desprovido de espécies nativas regenerantes e eram de uso intenso pelo gado; b) pasto com regeneração arbustiva, o qual apresentava em meio a braquiária muitos indivíduos regenerantes compostos principalmente por maria-mole (Senecio brasiliensis (Spreng.) Less.), Vassoura (Baccharis spp) e Solanum variabile Mart.; c) pasto com regeneração arbórea, o qual apresentava-se com regeneração arbustivoarbórea e encontrava-se principalmente em locais muito íngremes (de difícil manutenção) ou pouco usado pelo gado.

Era prática na região, inclusive na Fazenda Intermontes, a queima das áreas de pasto para renovação do capim, empobrecendo o solo e impedindo a regeneração natural. Após o início do projeto de restauração no ano de 2001, as primeiras medidas adotadas foram a retirada do gado e a proteção da área contra incêndios. 
A área em estudo está inserida na Província Geomorfológica do Planalto Atlântico, Zona do Planalto de Guapiara, que compreende a região elevada do alto da Serra de Paranapiacaba e estende-se até a cobertura sedimentar da bacia do Paraná. A região comporta os afluentes de alto curso da margem esquerda do Paranapanema, cuja borda sul marca o divisor de águas da drenagem continental (Vale do Paranapanema) e da litorânea (Vale do Ribeira) (CCRG, 2003)

A declividade dominante está entre 20 a $30 \%$, onde os fundos dos vales estão acima de $800 \mathrm{~m}$ de altitude e os espigões muitas vezes ultrapassam $1.000 \mathrm{~m}$ de altitude (CCRG, 2003).

Essas características definem para a região, segundo a classificação de Köeppen (1948), o clima temperado úmido sem estiagem (Cfb), que ocupa áreas do Planalto de Guapiara com altitudes superiores a $800 \mathrm{~m}$. Nessa parte mais alta da Serra de Paranapiacaba as temperaturas médias são inferiores a $18^{\circ} \mathrm{C}$ no mês mais frio e inferiores a $22^{\circ} \mathrm{C}$ no mês mais quente (Nimer, 1989; Setzer, 1966).

A precipitação média da bacia do Córrego do Chapéu, situada a $10 \mathrm{~km} \mathrm{da}$ Fazenda Intermontes, é de $1.300 \mathrm{~mm}$, variando de 1.100 e $1.500 \mathrm{~mm}$ por ano, com chuvas concentradas no verão, principalmente nos meses de dezembro, janeiro e fevereiro. Nessa região o período correspondente ao inverno é o que apresenta a maior redução dos índices pluviométricos. O total pluviométrico do mês mais seco é superior a $30 \mathrm{~mm}$ (CCRG, 2003). As temperaturas mínimas absolutas anuais chegam a $-4{ }^{\circ} \mathrm{C}$, nas altitudes mais elevadas, ocorrendo em média de um a cinco dias de geadas por ano (Nimer, 1989; Setzer, 1966).

\subsubsection{A vegetação regional}

A vegetação do município de Ribeirão Grande localiza-se no Planalto Atlântico do Estado de São Paulo, na divisa com a Província Costeira, próxima a escarpa do Planalto Atlântico, onde predomina a Floresta Estacional Semidecidual, mas devido à 
proximidade com a Serra de Paranapiacaba, apresenta muitas espécies típicas da Floresta Ombrófila Densa na composição florística local (CCRG, 2003).

A flora regional tem contribuições de várias formações. Na região do Parque Estadual de Intervales ocorrem as chamadas Florestas Ombrófilas, por desenvolveremse em clima úmido sem período de estiagem (Mantovani, 1994). No reverso da Serra de Paranapiacaba, estende-se até Capão Bonito, o estremo norte do domínio da Floresta de Araucárias, formação dos climas temperados quentes e úmidos ou subtropicais úmidos do Sul do Brasil (Klein, 1984). Nas drenagens do Vale do Paranapanema, originam-se provavelmente as espécies típicas de Floresta Estacional Semidecidual do interior dos Estados de São Paulo, Paraná e Minas Gerais (Mantovani, 1994).

As florestas da região encontram-se em estádios diferenciados de sucessão, resultado de ocupação para prática de agricultura por períodos variáveis e pela extração seletiva de madeira e do palmiteiro (Mantovani, 1994). Geralmente os trechos florestais melhor conservados encontram-se nas encostas mais íngremes ou em locais de difícil acesso.

3.2.3 Utilização do Zoneamento Ambiental como ferramenta para a determinação das diferentes situações ambientais destinadas à restauração

O Zoneamento Ambiental da propriedade foi obtido em agosto de 2001, através de dados secundários que se encontram no projeto de adequação ambiental e paisagística da Fazenda Intermontes. O zoneamento foi realizado através da análise de fotografias aéreas da propriedade, coloridas, nas escalas de 1:10.000, tiradas no ano de 1999 (Figura 2). 


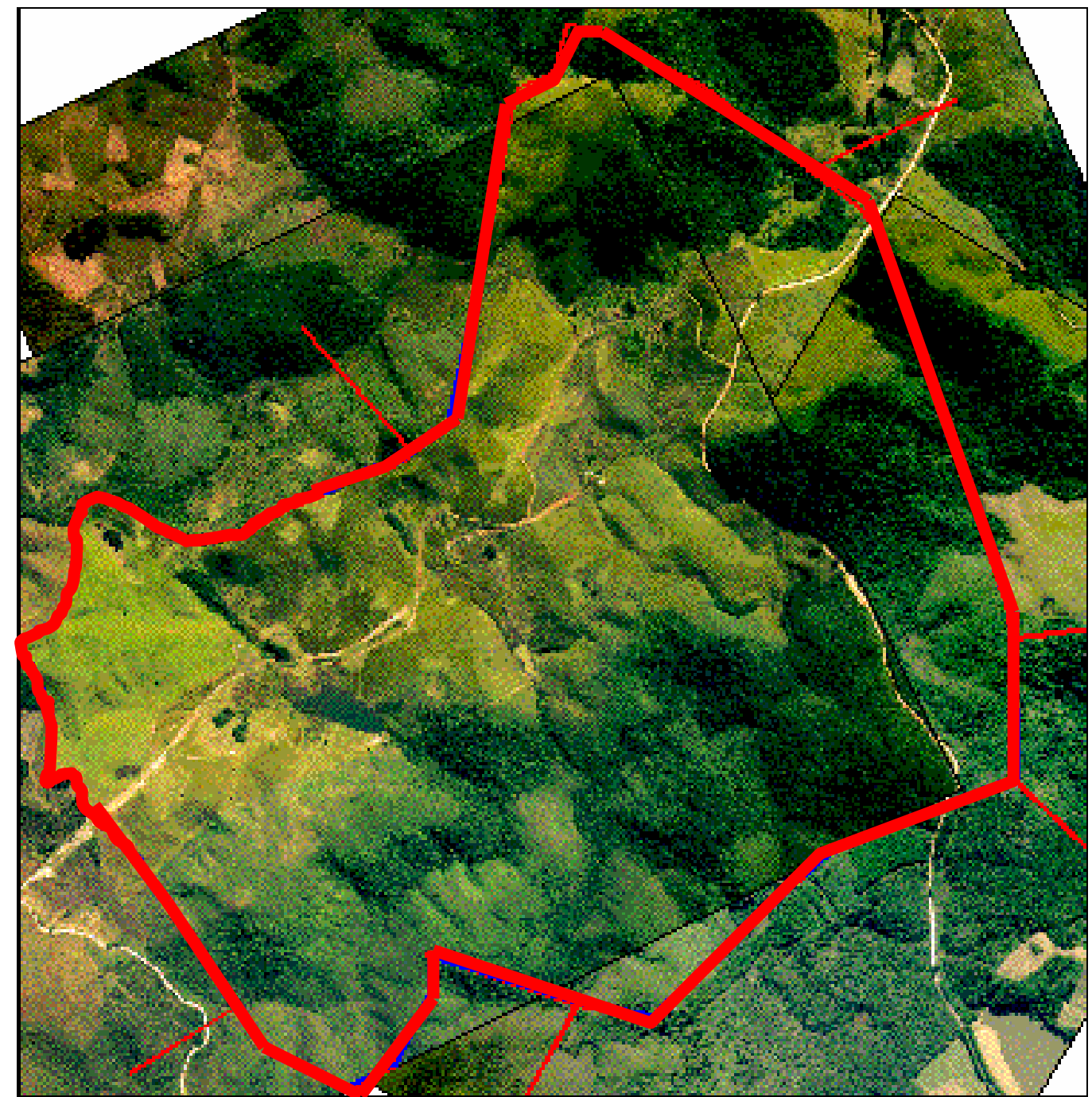

Figura 2 - Montagem do mosaico fotográfico compondo a Fazenda Intermontes e seus limites (em vermelho). Fotografias tiradas no ano de 1999, em escala original 1: 10.000

A fotointerpretação foi realizada através da sobreposição das fotografias aéreas digitalizadas com os mapas das propriedades, utilizando o programa AutoCAD ${ }^{\circledR} 2000 \mathrm{e}$ permitindo que situações visualizadas nas fotografias aéreas, como fragmentos florestais, pastos em uso, pastos abandonados, represa e outras situações, fossem repassadas para o mapa da propriedade. 
Após a fotointerpretação, foi realizada a checagem de campo em toda a propriedade, visando nesse momento, garantir a confirmação das situações ambientais identificadas na fotointerpretação e um detalhamento mais acurado dessas situações. A checagem também foi realizada para corrigir eventuais falhas ocorridas durante a análise das fotografias aéreas devido a alterações de uso do solo, detalhes não percebidos nas fotografias como indicadores de campo (indivíduos regenerantes) ou mesmo erros de interpretação no momento da análise da foto (Rodrigues et al., 2003a, 2003b, 2003c; Lopes et al., 2004; Rodrigues et al., 2004a; Rodrigues et al., 2004b).

A última etapa do Zoneamento Ambiental foi à elaboração do mapa final com situações de restauração florestal da propriedade. Para isso foi utilizado o software Adobe Photoshop 6.0. Nesta etapa, todas informações e detalhamentos obtidos pela fotointerpretação e checagem de campo foram repassados ao mapa da propriedade.

No total, a Fazenda Intermontes teve suas áreas divididas em 6 principais situações:

a) Pasto sem regeneração natural: pasto formado por Brachiaria decumbens Stapf sem a presença de indivíduos de espécies arbustivo-arbóreas nativos regenerantes;

b) Pasto com regeneração arbustiva: pasto formado por Brachiaria decumbens Stapf, com a presença de indivíduos arbustivos regenerantes em densidade maior que $2000 \mathrm{ind} . / \mathrm{ha}$;

c) Pasto com regeneração arbórea: pasto formado por Brachiaria decumbens Stapf com a presença de indivíduos de espécies arbustivo-arbóreas nativos regenerantes em densidade maior que 400 ind./ha;

d) Capoeira: área em processo de regeneração natural, apresentando fisionomia predominantemente florestal de baixo porte (2 a $6 \mathrm{~m}$ de altura) e poucas espécies arbóreas, geralmente dos estágios iniciais da sucessão. No geral, os indivíduos regenerantes apresentam baixo diâmetro no tronco. São situações provavelmente oriundas de pastos abandonados, onde houve corte raso, mas atualmente com baixa infestação de Brachiaria decumbens Stapf; 
e) Floresta: Florestas naturais onde houve a exploração seletiva de madeiras nobres e provavelmente de palmiteiro, sem ter tido corte raso. Apresentam uma boa diversidade de espécies e um porte de 12 a 20 metros de altura, dependendo do grau de degradação;

f) Solo sem vegetação: solo sem cobertura vegetal oriundo da deposição de subsolo em taludes da Fazenda ou de cortes no relevo para abertura de estradas.

Os nomes dados para cada situação encontrada, foram definidos durante a checagem de campo em função da fisionomia predominante na paisagem e ainda da presença de indivíduos de espécies arbustivo-arbóreas regenerantes, os quais apresentaram-se como possíveis indicadores de banco de sementes. As Figuras 3 e 4 mostram essas situações ambientais encontradas na Fazenda Intermontes.

O solo contendo o banco de sementes autóctone foi coletado em cinco das situações ambientais identificadas no Zoneamento Ambiental da Fazenda Intermontes, com exceção da situação de solo sem vegetação, uma vez que, durante sua construção, foi usado solo proveniente de camadas profundas (subsolo), as quais não possuem banco de sementes (Holthuijzen \& Boerboom, 1982; Dalling et al., 1997; Baider et al., 2001). A Figura 5 mostra o detalhe do subsolo usado na construção dos taludes após 6 meses de implantação, sem nenhuma regeneração e apresentando grandes sulcos de erosão, causados pelas enxurradas originadas na estrada adjacente. 


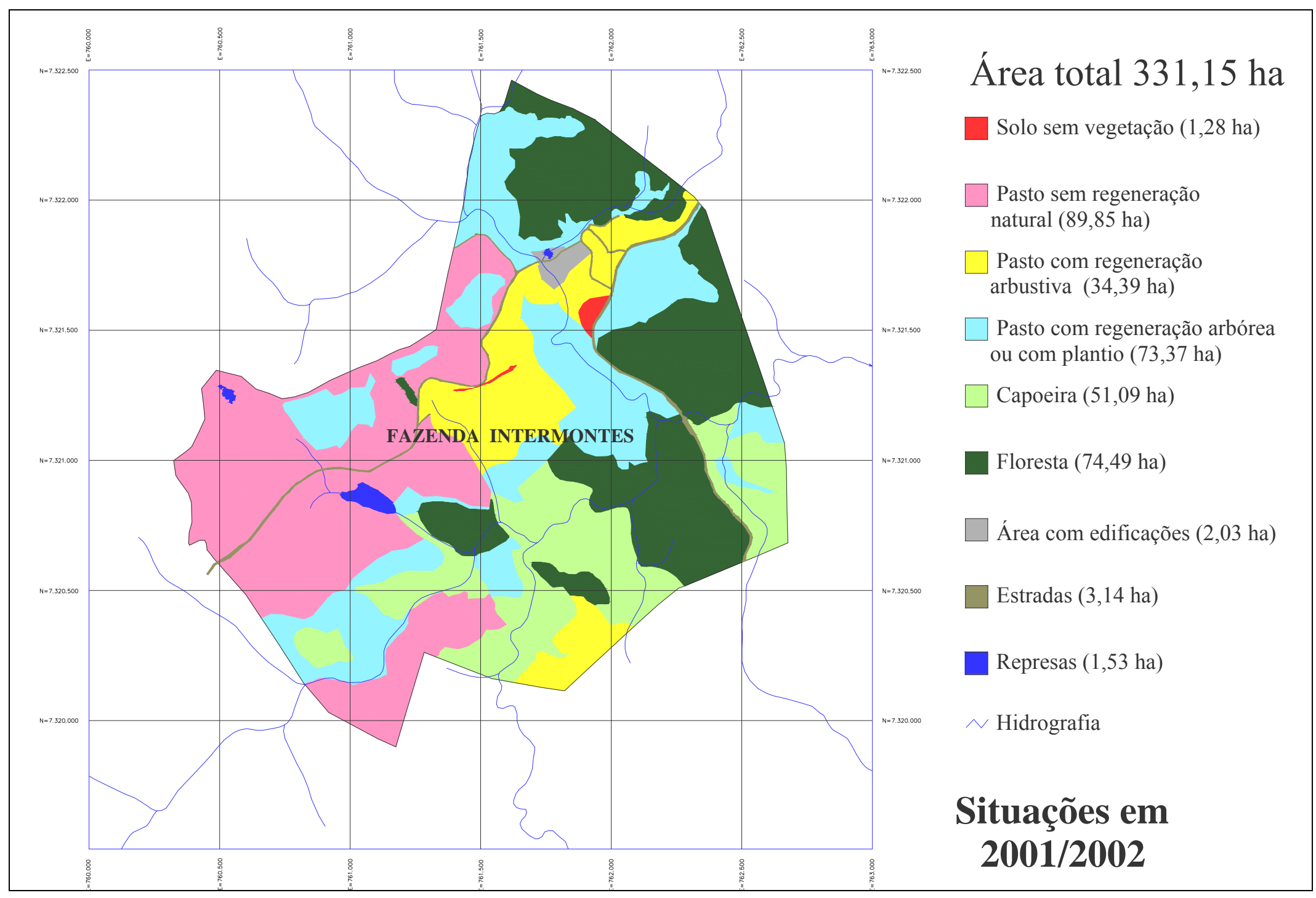

Figura 3 - Principais situações ambientais de restauração encontradas no Zoneamento Ambiental da Fazenda Intermontes, em agosto de 2001, CCRG, município de Ribeirão Grande, São Paulo 


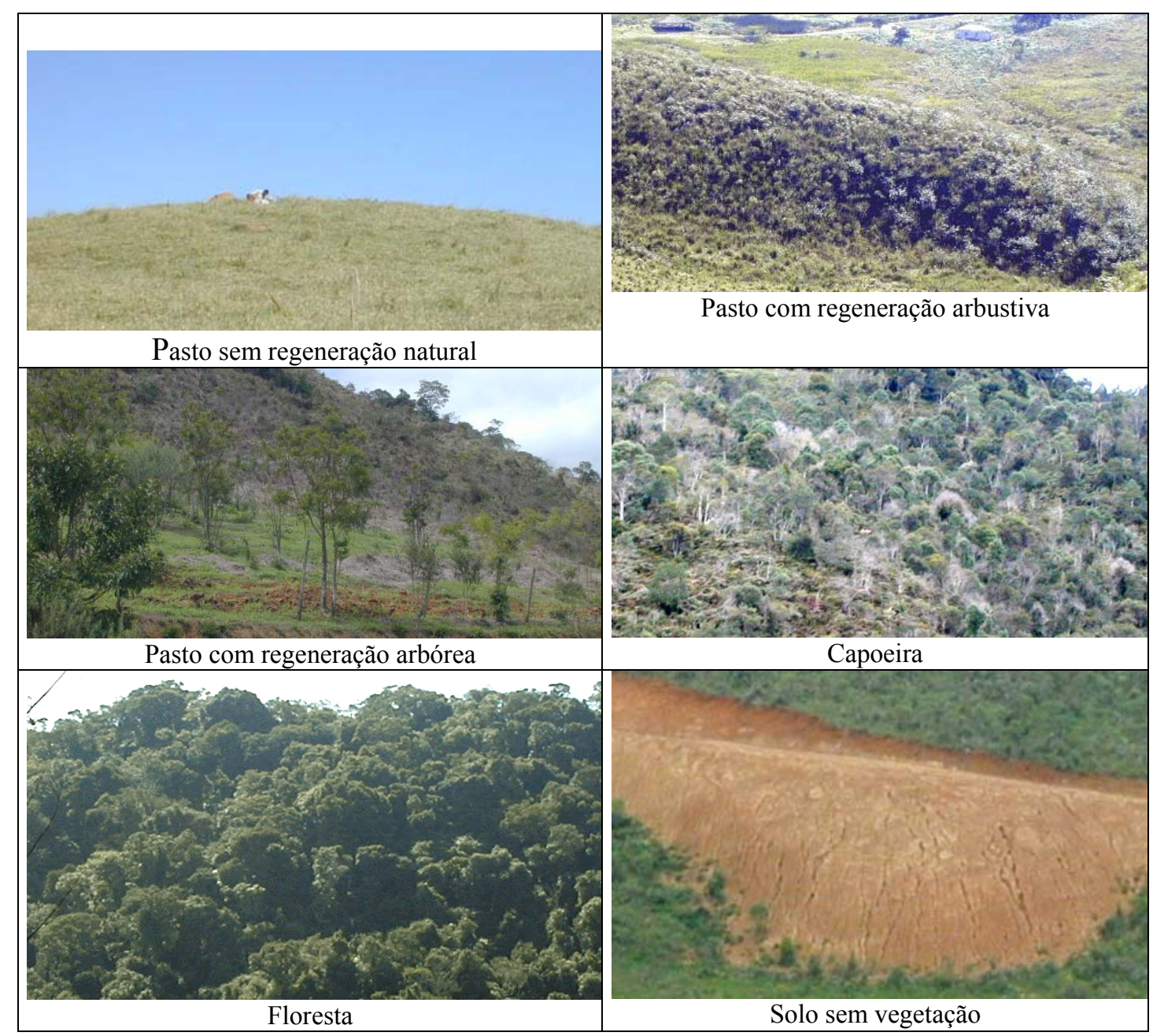

Figura 4 - Situações ambientais encontradas no Zoneamento Ambiental da Fazenda Intermontes, em agosto de 2001, CCRG, município de Ribeirão Grande, São Paulo 


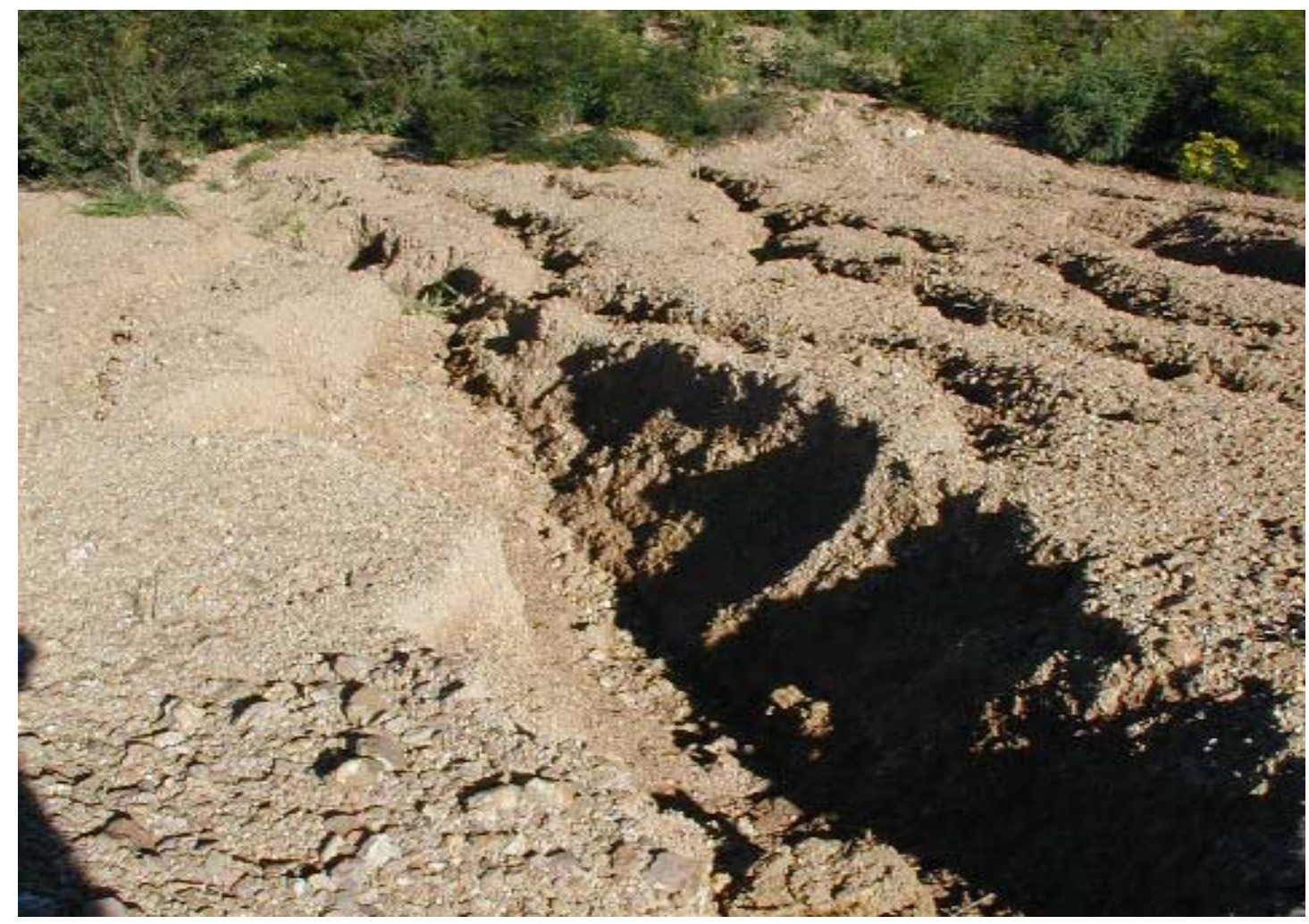

Figura 5 - Detalhe de erosão do subsolo usado na construção dos taludes, sem nenhuma regeneração natural após o período chuvoso, Fazenda Intermontes - CCRG, município de Ribeirão Grande, SP

Dessa forma, o acompanhamento da germinação de espécies arbustivo-arbóreas do banco de sementes autóctone foi realizado para 5 situações: a) pasto sem regeneração natural; b) pasto com regeneração arbustiva; c) pasto com regeneração arbórea; d) capoeira e; e) floresta.

\subsubsection{Coleta de dados}

As situações identificadas tiveram 16 amostras retiradas do solo, entre 0 a $3 \mathrm{~cm}$ de profundidade com exceção da situação de floresta, da qual foram coletadas apenas 8 parcelas, uma vez que, a mesma, por já estar numa condição relativamente bem 
preservada, deveria apresentar pouca variação na resposta de suas amostras, o que realmente foi comprovado em campo.

A profundidade de 0 a $3 \mathrm{~cm}$ adotada em função de representar grande parte do banco, uma vez que $60 \%$ das sementes se encontram nos primeiros 2,5 cm (Baider et al., 2001).

Para a situação de capoeira e floresta, toda folhagem que se encontrava sob o solo foi retirada. As amostras de solo contendo o banco de sementes autóctone foram retiradas de parcelas com dimensões de $0,5 \times 0,5 \mathrm{~m}$, totalizando $0,25 \mathrm{~m}^{2}$ (Figura 6). As parcelas foram distribuídas aleatoriamente em todas as situações identificadas através do sorteio de coordenadas "X" e "Y", tomadas a partir de alguma referência no campo como estradas, cercas, etc.

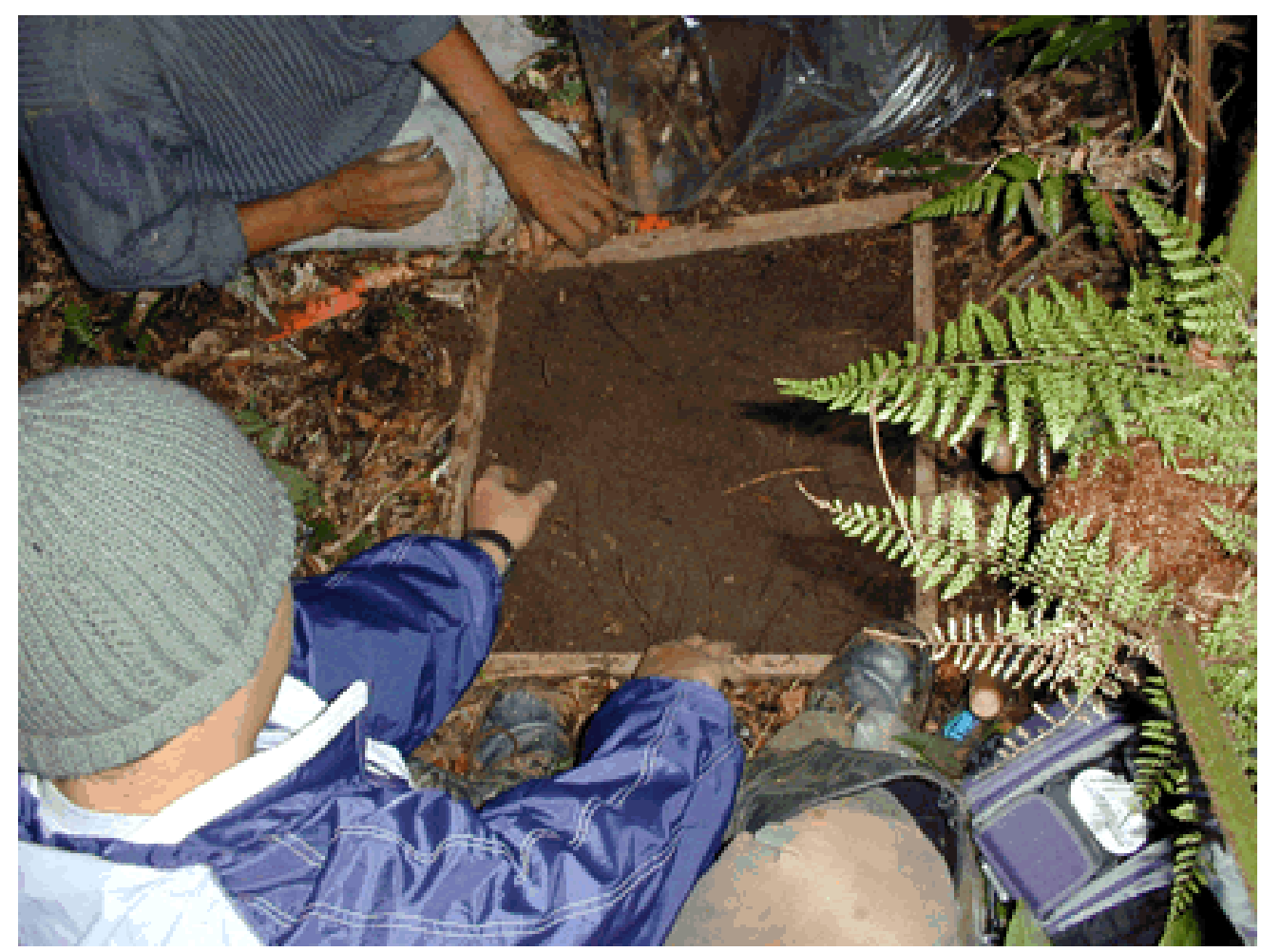

Figura 6 - Parcelas de $0,5 \times 0,5 \mathrm{~m}$ instaladas em uma das situações do Zoneamento Ambiental, para retirada de solo contendo o banco de sementes, Fazenda Intermontes, CCRG, município de Ribeirão Grande, SP 
A coleta do solo contendo o banco de sementes autóctone das diferentes situações ambientais foi realizada em junho de 2001. As amostras foram levadas para o Laboratório de Ecologia e Restauração Florestal (LERF) da ESALQ/USP, onde foram colocadas para germinar em canteiros de forma casualizada por meio de sorteios. Os canteiros foram montados dentro de sete dias após a coleta do solo contendo o banco de sementes em parcelas de 1,0 m de comprimento e 0,25 m de largura, somando os mesmos $0,25 \mathrm{~m}^{2}$ de onde as amostras foram retiradas. Além destas parcelas foram montadas mais 20 parcelas testemunhas que não receberam nenhum tipo de material. $\mathrm{O}$ objetivo das parcelas testemunhas foi de observar se poderia haver regeneração de espécies arbustivo-arbóreas através de chuva de sementes oriundas do entorno.

Os canteiros ficaram expostos ao tempo para imitar as condições de germinação em campo, após uma indução artificial, sem proteção de sombrite ou lonas plásticas. As parcelas foram irrigadas 2 vezes ao dia, no início da manhã e final da tarde, exceto nos dias de chuva. A Figura 7 apresenta parte dos canteiros de germinação em área experimental.

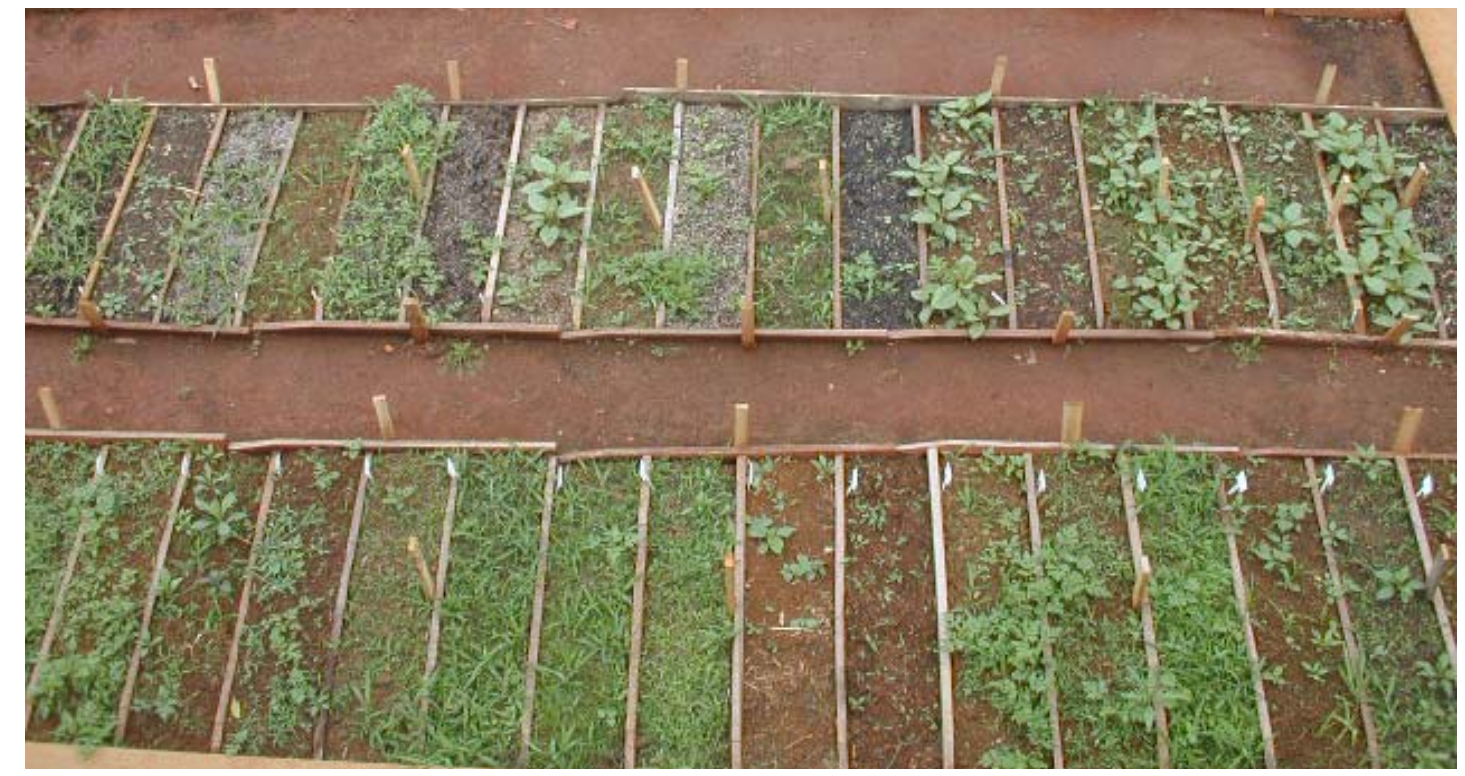

Figura 7 - Canteiros para germinação do Laboratório de Ecologia e Restauração Florestal, ESALQ/USP, Piracicaba, SP, onde foi colocado o banco de sementes das diferentes unidades do Zoneamento Ambiental da Fazenda Intermontes 
A germinação foi acompanhada ao longo de 3 meses, sendo que após esse período foi realizada a contagem de indivíduos de espécies arbustivo-arbóreas germinados em cada canteiro. A quantificação apenas dos indivíduos dessas duas formas de vida foi realizada pelo fato dessas classes serem responsáveis pela estruturação da florestal, criando ambientes propícios para chegada das outras formas de vida como epífitas, herbáceas, lianas não agressivas, etc.

Devido à dificuldade de identificação dos indivíduos arbustivos, quando recém germinados, foram quantificadas apenas a espécie Solanum variabile e a morfoespécie identificada como Baccharis spp. Essa última morfoespécie pode estar representando pelo menos 2 espécies distintas desse gênero, que são encontrados na Fazenda Intermontes, o Baccharis schultzii L. e o Baccharis dracunculifolia DC, mas que não puderam ser distinguidos enquanto plântulas. Após 3 meses a maioria dos canteiros foi coberta rapidamente por espécies invasoras, principalmente a Brachiaria decumbens Stapf, de tal forma que, a massa foliar das mesmas não permitiu a realização de mais uma contagem. A Figura 8 apresenta algumas espécies germinadas do banco de sementes autóctone.

Para a colocação das espécies nas suas respectivas famílias botânicas foi usado o sistema de classificação APG II (Angiosperm Phylogeny Group - APG II, 2003), mais aceito atualmente entre a maioria dos pesquisadores da área.

A classe sucessional das espécies resgatadas (Budowski, 1965, Whitmore, 1982) foi definida por meio do conceito de pioneiras (agrupando as pioneiras e secundárias iniciais) e não-pioneiras (agrupando as secundárias tardias e climácicas) (Kageyama \& Gandara, 2004), o qual é mais freqüentemente utilizado em trabalhos de restauração.

Durante o trabalho de revisão bibliográfica foram observadas diferenças na classificação sucessional de algumas espécies por diferentes autores. A inexistência de um consenso entre os pesquisadores (Barbosa, 2004; Kageyama \& Gandara, 2004) fez com que fossem consultados vários trabalhos (Gandolfi, 1991, Gandolfi et al., 1995; Leitão Filho et al., 1993; Gabriel, 1997; Albuquerque, 1999; Fundação Florestal, 2004) e assumida a classificação em que a espécie predominava. 


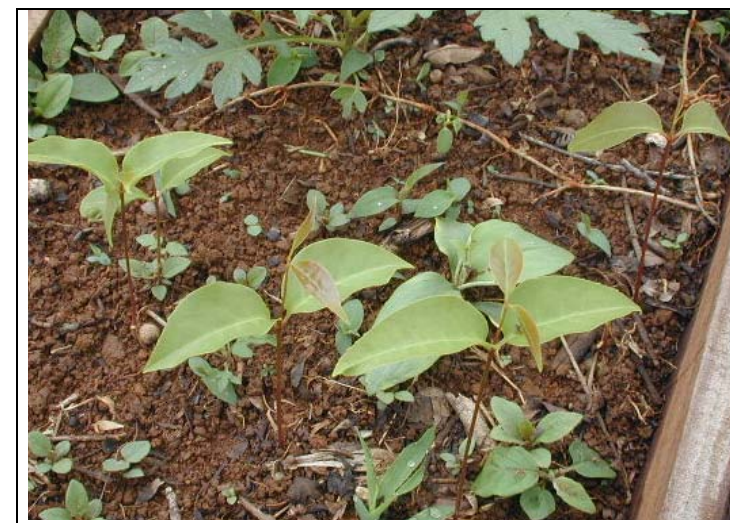

Indivíduos de Prunus myrtifolia germinados na parcela de capoeira.

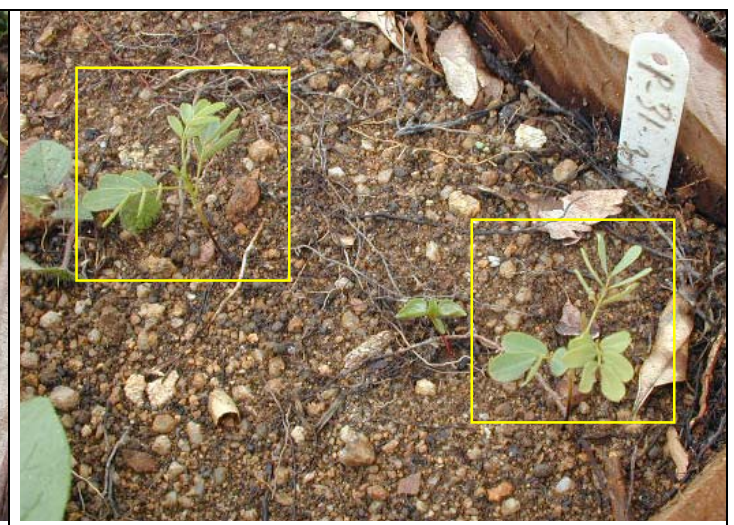

Indivíduos de Senna multijuga germinados na parcela de capoeira.

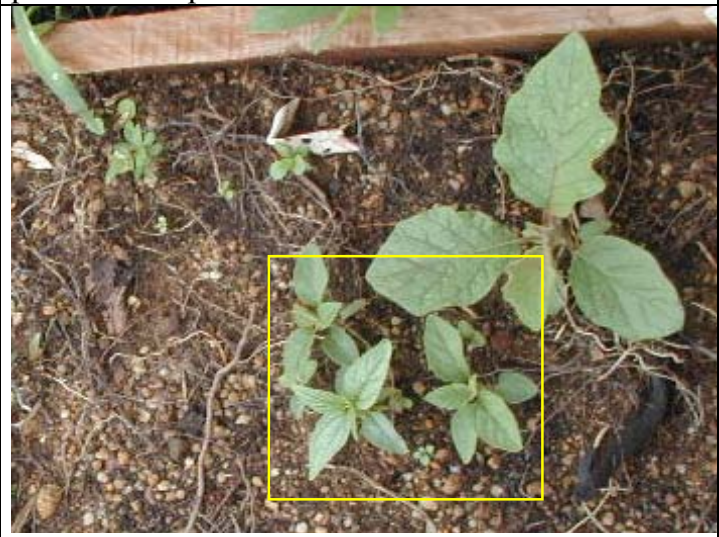

Indivíduos de Trema micrantha e Solanum variabile germinados na parcela de capoeira.

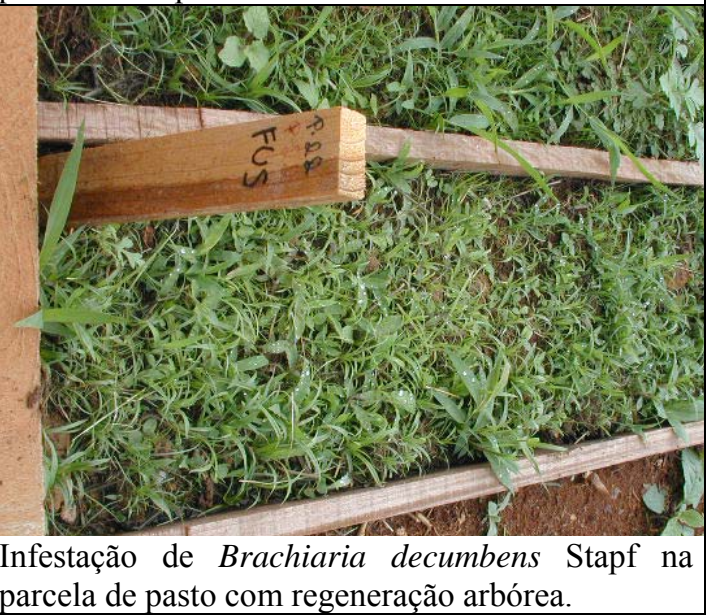

parcela de pasto com regeneração arbórea.

Figura 8 - Detalhe de indivíduos de espécies arbustivo-arbóreas germinados no banco de sementes autóctone após um mês de instalação do experimento, Laboratório de Ecologia e Restauração Florestal (LERF/USP), Piracicaba, SP

\subsubsection{Análises estatísticas}

As análises estatísticas foram realizadas visando a comparação do número de indivíduos de espécies arbustivo-arbóreas germinados nas cinco situações estudadas: A) pasto sem regeneração natural; B) pasto com regeneração arbustiva; C) pasto com regeneração arbórea; D) capoeira e; E) floresta.

A hipótese testada é de que nas cinco situações ocorram resultados diferenciados em termos da germinação, sendo maior nas situações pouco perturbadas e menor nas situações mais perturbadas. Considerou-se um delineamento amostral no qual 
parcelas foram aleatoriamente distribuídas em áreas características das cinco situações estudadas.

Como se deseja comparar mais de 2 situações, foi aplicado um teste estatístico não-paramétrico de Kruskal-Wallis (Campos, 1983) com objetivo de comparar o número total de indivíduos.

Havendo indícios de diferença entre os dados em pelo menos duas situações, por aproximação de qui-quadrado do teste de Kruskal-Wallis, foram feitas comparações múltiplas de médias através do teste de Wilcoxon, que permite a comparação das situações, duas a duas.

Para esse estudo foi assumido um nível de significância de 5\%. Os dados foram processados no programa SAS (SAS Institute Inc., 1999).

\subsection{Resultados e Discussão}

A Tabela 1 apresenta os resultados da germinação de espécies arbustivo-arbóreas oriundas do banco de sementes autóctone de 5 situações da Fazenda Intermontes, mostrando as diferenças dos números de indivíduos de espécies arbustivo-arbóreas germinados entre as situações analisadas. Somando-se as duas formas de vida (arbórea e arbustiva) são apresentadas as médias de $0,1,06,1,69,11,81$ e 17,25 indivíduos por parcela, respectivamente para as situações de pasto sem regeneração natural, pasto com regeneração arbustiva, pasto com regeneração arbórea, capoeira e floresta. Esses valores insinuam um aumento contínuo no número de indivíduos regenerantes conforme a complexidade do ambiente.

Observa-se que o número de indivíduos foi significativamente maior na situação de floresta (E) em relação a todos os demais tratamentos (Figura 9). Em seguida, o número de espécies foi maior na situação de capoeira (D) que, por sua vez, foi inferior ao da situação floresta, porém, superior as demais situações. 
Tabela 1. Situações ambientais de recuperação e os resultados da germinação do banco de sementes das camadas de 0 a $3 \mathrm{~cm}$ de solo. C.S. = classificação sucessional; $\mathrm{P}=$ pioneira; $\mathrm{NP}=$ não pioneira; $\mathrm{T}=$ Tamanho da semente; $\mathrm{m}=$ média $\mathrm{p}=$ pequena $\mathrm{F} . \mathrm{V}$. $=$ Forma de vida; Arv = árvore; Arb $=$ arbusto. $\mathrm{dp}=$ desvio padrão

\begin{tabular}{|c|c|c|c|c|c|c|c|c|}
\hline Situação & Espécie & $\mathbf{T}$ & C.S. & $\begin{array}{c}\text { Ind. } \\
\text { Amos. }\end{array}$ & F.V. & $\begin{array}{l}\text { Ind. } \\
\text { totais } \\
\text { Amos. }\end{array}$ & $\begin{array}{l}\text { Média/ } \\
\text { parcela } \\
\text { (dp) }\end{array}$ & $\begin{array}{c}\text { Dens. } \\
\text { por ha } \\
\text { (estimada) } \\
\end{array}$ \\
\hline Testemunha & ---------- & - & - & 0 & - & 0 & 0,00 & 0 \\
\hline $\begin{array}{l}\text { Pasto sem } \\
\text { reg. natural } \\
(0-3 \mathrm{~cm})\end{array}$ & ---------- & - & - & 0 & - & 0 & $\begin{array}{c}0,00 \\
(0)\end{array}$ & 0 \\
\hline $\begin{array}{l}\text { Pasto c/ reg. } \\
\text { arbustiva } \\
(0-3 \mathrm{~cm})\end{array}$ & $\begin{array}{l}\text { Trema micrantha }(\mathrm{L} .) \text { Blume } \\
\text { Solanum variabile Mart. } \\
\text { Baccharis sp }\end{array}$ & $\begin{array}{l}\mathrm{p} \\
\mathrm{p} \\
\mathrm{p}\end{array}$ & $\begin{array}{l}\mathrm{P} \\
\mathrm{P} \\
\mathrm{P}\end{array}$ & $\begin{array}{c}1 \\
2 \\
14\end{array}$ & $\begin{array}{l}\text { Arv } \\
\text { Arb }\end{array}$ & $\begin{array}{c}1 \\
16\end{array}$ & $\begin{array}{c}1,06 \\
(1,91)\end{array}$ & 42.500 \\
\hline $\begin{array}{l}\text { Pasto c/ reg. } \\
\text { arbórea } \\
(0-3 \mathrm{~cm})\end{array}$ & $\begin{array}{l}\text { Solanum granuloso-leprosum Dunal } \\
\text { Croton lindenianus A. Rich. } \\
\text { Solanum variabile Mart. } \\
\text { Baccharis sp }\end{array}$ & $\begin{array}{l}\mathrm{p} \\
\mathrm{p} \\
\mathrm{p} \\
\mathrm{p}\end{array}$ & $\begin{array}{l}P \\
P \\
P \\
P\end{array}$ & $\begin{array}{l}14 \\
2 \\
5 \\
6\end{array}$ & $\begin{array}{l}\text { Arv } \\
\text { Arb }\end{array}$ & 16 & $\begin{array}{l}1,69 \\
(2,98)\end{array}$ & 67.500 \\
\hline $\begin{array}{c}\text { Capoeira } \\
(0-3 \mathrm{~cm})\end{array}$ & $\begin{array}{l}\text { Croton lindenianus A. Rich. } \\
\text { Solanum granuloso-leprosum Dunal } \\
\text { Prunus myrtifolia (L.) Urb. } \\
\text { Trema micrantha (L.) Blume } \\
\text { Zanthoxylum rhoifolium Lam. } \\
\text { Alchornea triplinervia (Spreng.)Müll. Arg. } \\
\text { Acnistus arborescens (L.) Schltdl } \\
\text { Senna multijuga (Rich.) H.S.Irwin \& Barneby } \\
\text { Croton floribundus } \\
\text { Solanum variabile Mart. } \\
\text { Baccharis spp. }\end{array}$ & $\begin{array}{l}\mathrm{p} \\
\mathrm{p} \\
\mathrm{m} \\
\mathrm{p} \\
\mathrm{p} \\
\mathrm{p} \\
\mathrm{p} \\
\mathrm{p} \\
\mathrm{p} \\
\mathrm{p} \\
\mathrm{p}\end{array}$ & $\begin{array}{l}P \\
P \\
P \\
P \\
P \\
P \\
P \\
P \\
P \\
P \\
P\end{array}$ & $\begin{array}{c}3 \\
15 \\
13 \\
2 \\
4 \\
2 \\
4 \\
7 \\
13 \\
25 \\
101\end{array}$ & Arv & 126 & $\begin{array}{c}11,81 \\
(12,90)\end{array}$ & 472.500 \\
\hline $\begin{array}{l}\text { Floresta } \\
(0-3 \mathrm{~cm})\end{array}$ & $\begin{array}{l}\text { Solanum granuloso-leprosum Dunal } \\
\text { Prunus myrtyfolia (L.) Urb. } \\
\text { Trema micrantha (L.) Blume } \\
\text { Senna multijuga (Rich.) H.S.Irwin \& Barneby } \\
\text { Zanthoxylum rhoifolium Lam. } \\
\text { Acnistus arborescens (L.) Schltdl } \\
\text { Alchornea triplinervia (Spreng.) Müll. Arg. } \\
\text { Baccharis spp. } \\
\text { Solanum variabile Mart. }\end{array}$ & $\begin{array}{l}\mathrm{p} \\
\mathrm{m} \\
\mathrm{p} \\
\mathrm{p} \\
\mathrm{p} \\
\mathrm{p} \\
\mathrm{p} \\
\mathrm{p} \\
\mathrm{p}\end{array}$ & $\begin{array}{l}\mathrm{P} \\
\mathrm{P} \\
\mathrm{P} \\
\mathrm{P} \\
\mathrm{P} \\
\mathrm{P} \\
\mathrm{P} \\
\mathrm{P} \\
\mathrm{P}\end{array}$ & $\begin{array}{c}63 \\
1 \\
27 \\
3 \\
4 \\
21 \\
3 \\
3 \\
13 \\
\end{array}$ & Arv & $244^{*}$ & $\begin{array}{l}17,25 \\
(6,67)\end{array}$ & 690.000 \\
\hline
\end{tabular}

Teste de Kruskall-Wallis: Qui-quadrado: 50.8809 DF: 4 valor-p: $<.0001$ * - estimado

As situações pasto com regeneração arbustiva e pasto com regeneração arbórea (B e C) não poderam ser consideradas como possuidoras de médias diferentes, 
entretanto, a média destas duas situações diferiram significativamente da média dos demais tratamentos.

Por fim, a média da situação pasto sem regeneração natural (A) apresentou média inferior a todas as demais.

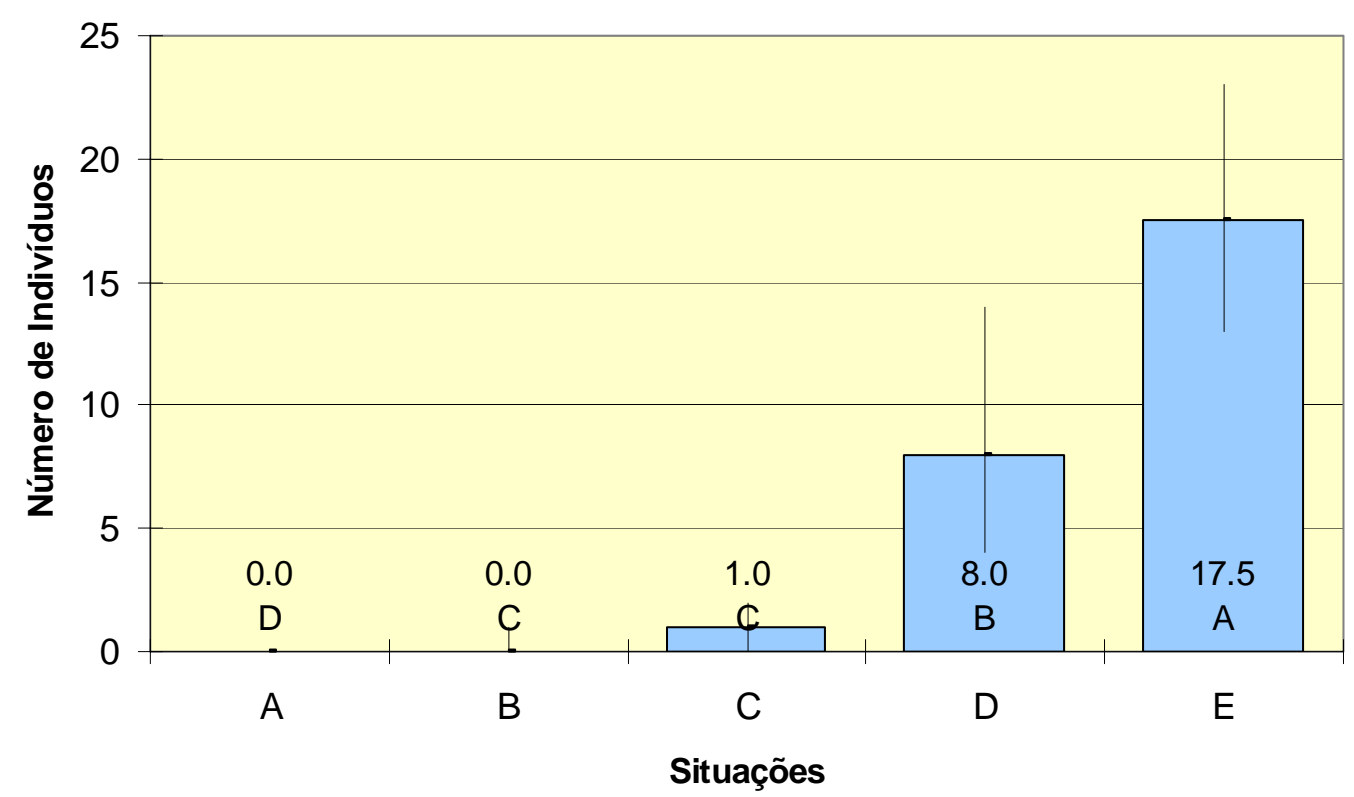

\footnotetext{
Figura 9 - Número de indivíduos (mediana e intervalo inter-quartis) das diversas situações estudadas. Barras com letras iguais não diferem entre si pelo teste de Wilcoxon com nível de significância alfa de $5 \%$. A) pasto sem regeneração natural; B) pasto com regeneração arbustiva; C) pasto com regeneração arbórea; D) capoeira e; E) floresta
}

Quando os valores de densidade de indivíduos amostrados foram analisados separando-se as duas formas de vida (arbustivo ou arbórea), ficou mais evidente a diferença entre as situações identificadas (Figura 10). A primeira situação de pasto sem regeneração natural, não apresentou nenhum indivíduo arbustivo ou arbóreo germinado do banco de sementes autóctone. O pasto com regeneração arbustiva apresentou apenas 1 indivíduo arbóreo, mas destacou-se da situação de pasto sem regeneração pelo número de indivíduos arbustivos germinados no banco de sementes autóctone. As outras 3 
situações, pasto com regeneração arbórea, capoeira e floresta, apresentaram indivíduos de espécies arbóreas em quantidades bem distintas, sendo 16, 63 e 244, respectivamente.

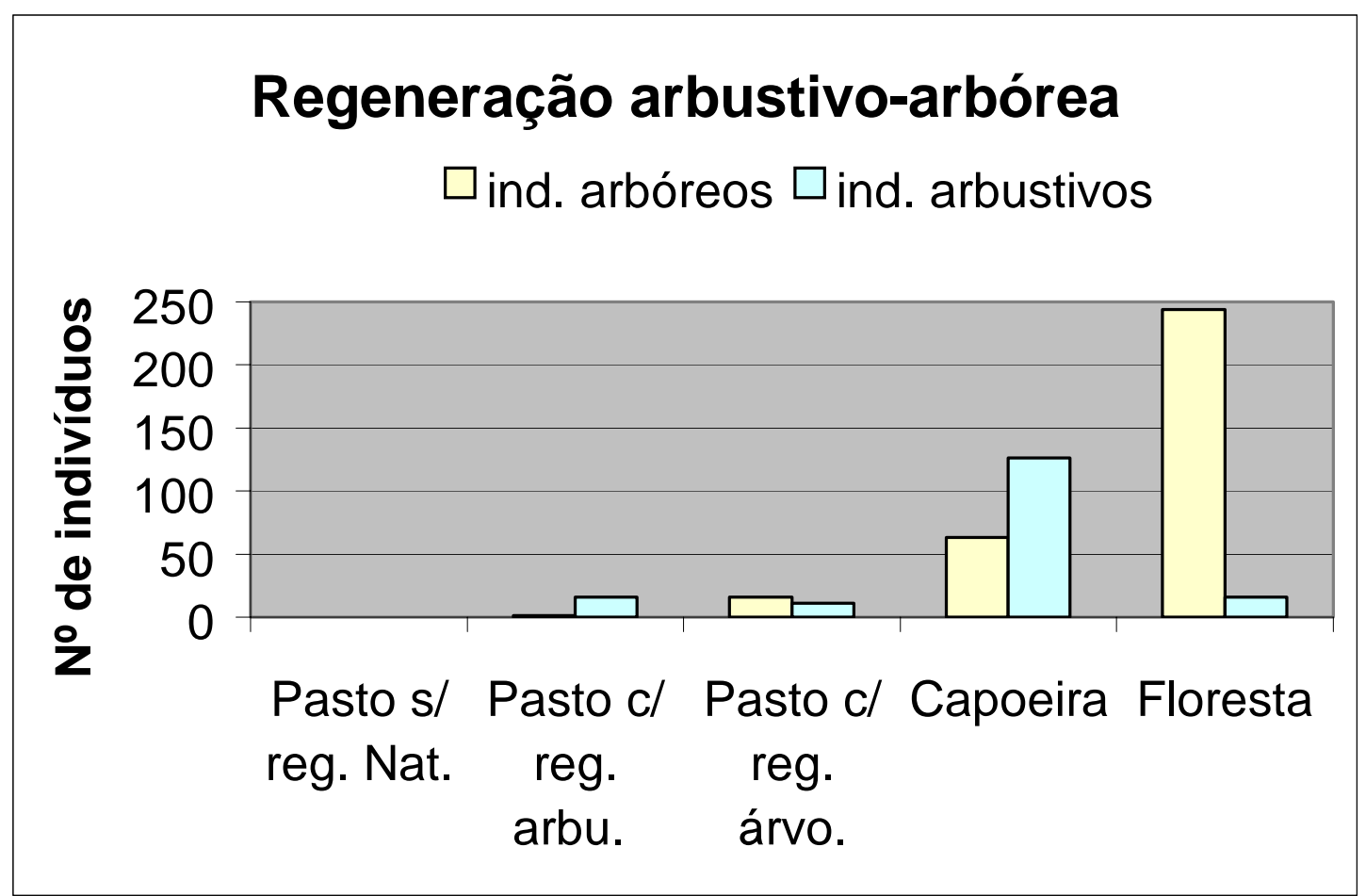

Figura 10 - Densidade de indivíduos arbóreos e arbustivos regenerados do banco de sementes autóctone em cada uma das situações analisadas na Fazenda Intermontes, CCRG, SP

A densidade de indivíduos de espécies arbustivas apresentou-se baixa nas fisionomias de pasto e floresta, mas elevada na situação de capoeira. Esse fato pode mostrar como deve estar ocorrendo o balanço de entrada (causado pela chuva de sementes) e saída (causada pela mortalidade, predação e germinação das sementes) das sementes de espécies arbustivas no banco de sementes autóctone. Provavelmente as áreas de capoeira são onde as espécies arbustivas conseguem melhor se reproduzir em função da ausência de cortes dos seus indivíduos por roçagem ou pastagem e ainda pela quantidade de luz incidente, uma vez que esse ambiente ainda permanece parcialmente aberto e as espécies arbustivas amostradas são predominantemente heliófitas (Tabela 1). 
Nessas condições, qualquer falha no processo sucessional, provocada por perturbações naturais ou antrópicas ou mesmo ausência de espécies de estágio mais avançado da sucessão, pode acionar este banco de sementes e fazer com que estas espécies arbustivas atuem como colonizadoras do local.

Chama a atenção na Tabela 1 , a alta densidade estimada por hectare de indivíduos de espécies arbustivo-arbóreas germinados nas situações que apresentaram banco de sementes. Esses valores são muito elevados se comparados com o número de indivíduos adultos que serão estabelecidos numa floresta, cujo valor é aproximadamente 2.000 indíviduos por hectare com Perimetro a Altura do Peito (PAP) $\geq 15 \mathrm{~cm}$ (Mantovani et al., 1990; César \& Monteiro, 1995; Ivanauskas et al., 2001). Portanto, é esperado que a alta densidade inicial defina uma elevada competição entre plântulas ou indivíduos jovens, baixando sua densidade para um número de indivíduos próximo a de uma área de floresta natural, quando atingirem a fase adulta.

Devemos considerar ainda que esta expressão da regeneração natural está subestimada, uma vez que, estes resultados são apenas da camada superficial com até 3 $\mathrm{cm}$ de profundidade. Outro fator que deve influenciar na germinação das sementes do banco é a profundidade em que a mesma se encontra quando posta para germinar. Certamente, sementes pequenas como a de Trema micrantha e Zanthoxylum rhoifolium, quando colocadas para germinar em camadas mais profundas, podem não receber o estímulo necessário de luz para quebra de dormência, mantendo-se dormentes no estoque de sementes do solo. Isso deve ter ocorrido com efeito reduzido nesse experimento, dada a pequena espessura de solo usada $(3 \mathrm{~cm})$.

Também é importante ressaltar que os indivíduos regenerados no banco de sementes não apresentaram apenas a forma de vida arbustivo-arbórea, mas sim, várias outras formas de vida como herbáceas e lianas não computadas nesse trabalho e que podem contribuir com o resgate da diversidade vegetal.

Somando-se todas as situações estudadas, no total, foram encontras 11 espécies arbustivo-arbóreas, sendo 9 espécies arbóreas e 2 arbustivas (Tabela 1). Todas as 11 espécies encontradas pertencem ao grupo ecológico das pioneiras. A contribuição do banco de sementes na regeneração, em sua maior parte, é apenas, em termos de grupos 
ecológicos, dos estágios iniciais de sucessão (Baider et al., 2001), sem restabelecer a riqueza de espécies lenhosas, já que poucas espécies permanecem ativas no banco de sementes, principalmente as espécies mais finais de sucessão (Holthuijen \& Boerboom, 1982; Garwood, 1989; Almeida-Cortez, 2004).

É importante ressaltar que esse grupo de espécies pioneiras tem como função na floresta, a cicatrização de clareiras ou ainda o recobrimento de áreas degradadas, sendo fundamentais no início das atividades de restauração florestal (Rodrigues \& Gandolfi, 2004; Kageyama \& Gandara, 2004). Desta maneira, o efetivo estabelecimento das espécies pioneiras de forma homogênea nas áreas de restauração, implicaria num posterior enriquecimento de espécies finais da sucessão nessa área, caso essas espécies não se estabeleçam na área num futuro próximo, pela ação de dispersores oriunda dos fragmentos remanescentes no entorno.

Em relação ao número de espécies encontradas em cada uma das situações ambientais estudadas, a Figura 11 mostra um baixo número de espécies arbóreas para as fisionomias de pasto, correspondendo apenas a 1 espécie para o pasto com regeneração arbustiva e 2 espécies para o pasto com regeneração arbórea e nenhuma espécie para o pasto sem regeneração arbustiva.

As fisionomias de capoeira e floresta apresentaram as maiores riquezas em espécies arbóreas, sendo 9 e 7 espécies arbóreas, respectivamente em cada uma delas. O número mais baixo para floresta pode estar ligado ao número menor de amostras desta situação. A situação de capoeira foi a única a apresentar todas as espécies germinadas do banco de sementes autóctone.

Vale lembrar que, a composição do banco de sementes varia ao longo das estações do ano, sendo que, em função da longevidade dos diásporos, os bancos podem ser caracterizados como transitórios, ou seja, formados por sementes de curta viabilidade, ou persistentes, compostos por sementes de maior longevidade sob condições naturais (Grombone-Guaratini \& Rodrigues, 2002; Almeida-Cortez, 2004). 


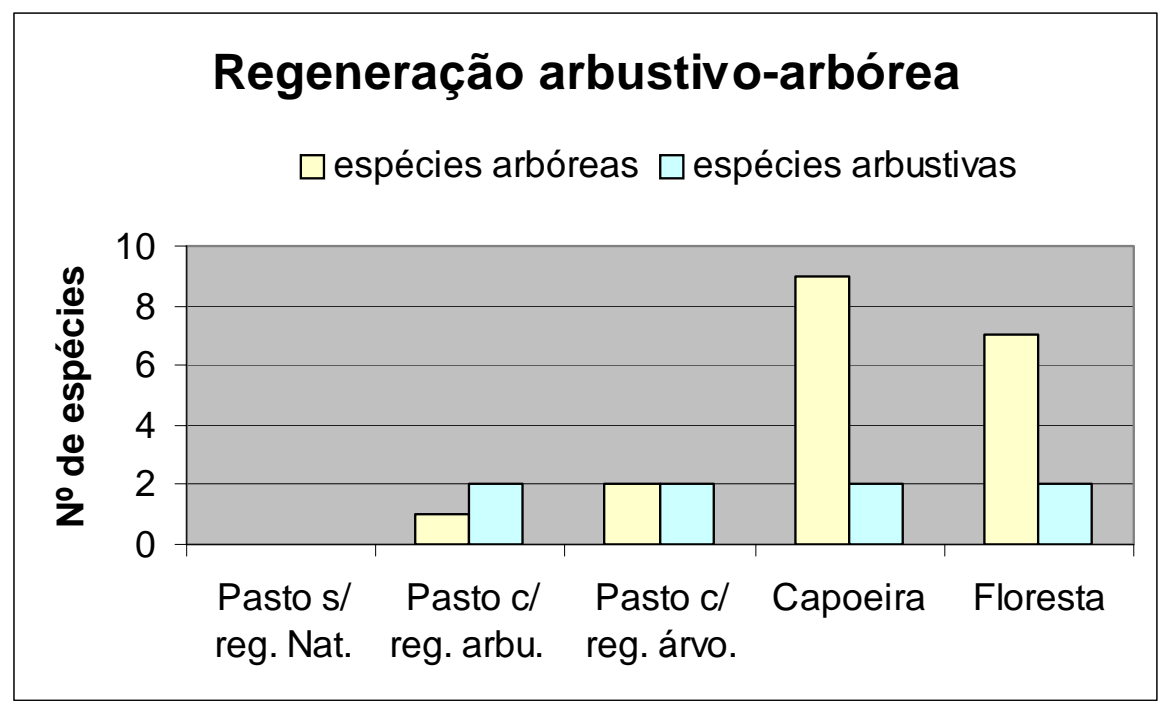

Figura 11 - Número de espécies arbóreas e arbustivas regeneradas do banco de sementes autóctone em cada uma das situações analisadas na Fazenda Intermontes, CCRG, SP

A ausência de espécies finais de sucessão entre as espécies germinadas do banco de sementes pode ser conseqüência da formação de banco transitório ou temporário, característica típica desse grupo de espécies. Além disso, a época de coleta pode ter influenciado bastante na amostragem de apenas espécies pioneiras, uma vez que a produção de sementes em junho pelas espécies arbóreas, neste tipo de formação florestal é baixa (Figliolia, 1995; Lorenzi, 2002), o que favorece a coleta do banco de sementes persistentes. Nesse sentido, pode se dizer que o banco foi subamostrado, devendo apresentar várias outras espécies ao longo do ano, dos estádios mais avançados da sucessão. Assim, uma amostragem mais fiel do banco de sementes autóctone, principalmente para fins de pesquisa com banco de sementes, exigiria coletas mensais ou até quinzenais (Grombone-Guaratini \& Rodrigues, 2002).

Embora a germinação de sementes de braquiária não tenha sido quantificada nas parcelas das situações de pasto, apresentaram-se com uma grande densidade de indivíduos, que dominaram o canteiro a partir do terceiro mês, abafando e matando mudas de espécies arbustivo-arbóreas nativas. Estudos em pastagens mostram que muitas plântulas morrem nos estágios iniciais de desenvolvimento devido à alta taxa de 
predação por insetos e mamíferos ou mesmo pela competição com gramíneas (Nepstad et al., 1998). As gramíneas em geral, interferem no desenvolvimento de plântulas competindo por luz, nutrientes e espaço, constituindo uma barreira física e as vezes até química para espécies lenhosas (Miriti, 1998; Toledo et al., 2001). Em áreas recém reflorestadas, que ainda não foram sombreadas, essas gramíneas irão atuar como um impedimento para o estabelecimento de mudas e das sementes dispersas na área (Vieira, 2004). Provavelmente essa mesma situação aconteça em campo, caso não ocorra uma forma de controle efetivo da braquiária. Nesse sentido, torna-se importante o estudo de métodos que controlem as gramíneas ou outras espécies invasoras agressivas, favorecendo assim, o estabelecimento das espécies arbustivo-arbóreas.

Dentro deste contexto, é possível definir metodologias de restauração para as situações analisadas, permitindo a escolha de ações diferenciadas para cada uma e visando o aumento do sucesso da restauração florestal, com os menores custos possíveis e as maiores chances de perpetuação a longo prazo.

A adoção de um ou outro sistema dependerá das características de cada situação encontrada no campo, no que se refere à cobertura vegetal da área (atual e pretérita), histórico de uso que define a existência ou não de propágulos (banco de sementes e propagação vegetativa) de espécies lenhosas e a proximidade de remanescentes florestais bem conservados, que podem atuar como possíveis fornecedores de propágulos pela chuva de sementes (Rodrigues et al., 2001; Rodrigues et al., 2003a, 2003b, 2003c; Lopes et al., 2004; Rodrigues et al., 2004b).

Portanto, a cobertura vegetal do solo das situações identificadas foi fundamental para definição das metodologias de restauração, sendo classificadas em 3 grupos: a) solo sem vegetação (taludes); b) pasto com braquiária e; c) floresta (situações de capoeira e floresta). Essa classificação foi importante para definir a existência ou não da matocompetição com os indivíduos regenerantes.

Em situações de subsolo exposto, os indivíduos regenerantes, oriundos de uma transferência de banco de sementes alóctone, terão menos competição com plantas invasoras. Já as áreas de pastagens cobertas por braquiária, poderão apresentar dificuldades de estabelecimento de plântulas de espécies nativas, uma vez que, o 
abafamento e a ação de substâncias alelopáticas, produzidas pela braquiária, irão inibir a germinação e desenvolvimento dessas espécies (Toledo et al., 2001). As situações com cobertura florestal (capoeira e floresta), apresentam as melhores condições para o desenvolvimento da regeneração natural, devido à baixa infestação de espécies invasoras e melhores condições edáficas, diminuindo as atividades de restauração e a manutenção da área, tendo como resultado o barateamento do processo.

Com os dados obtidos sobre o banco de sementes autóctone e a cobertura do solo das situações de restauração da Fazenda Intermontes foi possível definir propostas diferenciadas de restauração para cada uma das situações identificadas no Zoneamento Ambiental da Fazenda Intermontes (Tabela 2).

Tabela 2. Definição das metodologias de restauração na Fazenda Intermontes em função da presença de banco de sementes nativas e cobertura do solo

\begin{tabular}{|c|c|c|c|}
\hline $\begin{array}{l}\text { Situação de } \\
\text { Restauração }\end{array}$ & $\begin{array}{c}\text { Regeneração do } \\
\text { banco de sementes } \\
\text { autóctone }\end{array}$ & $\begin{array}{c}\text { Mato- } \\
\text { competição }\end{array}$ & $\begin{array}{c}\text { Metodologia de } \\
\text { restauração, visando o } \\
\text { resgate da biodiversidade }\end{array}$ \\
\hline $\begin{array}{l}\text { Solo sem } \\
\text { vegetação }\end{array}$ & Sem regeneração & Não & $\begin{array}{l}\text { Transferência de banco de } \\
\text { sementes alóctone ou implantação } \\
\text { total }\left(1.667^{*} \text { ind./ha }\right)\end{array}$ \\
\hline $\begin{array}{l}\text { Pasto sem } \\
\text { regeneração } \\
\text { natural }\end{array}$ & Sem regeneração & Alta & $\begin{array}{l}\text { Implantação total }(1.667 * \text { ind./ha) } \\
\text { e controle de competidores }\end{array}$ \\
\hline $\begin{array}{l}\text { Pasto c/ } \\
\text { regeneração } \\
\text { arbustiva }\end{array}$ & Baixo & Alta & $\begin{array}{l}\text { Indução do banco autóctone } \\
\text { através de revolvimento do solo, } \\
\text { implantação total (1.667* ind./ha) } \\
\text { e controle de competidores }\end{array}$ \\
\hline $\begin{array}{l}\text { Pasto c/ } \\
\text { regeneração } \\
\text { arbórea }\end{array}$ & Médio & Alta & $\begin{array}{l}\text { Indução do banco através de } \\
\text { revolvimento do solo, condução da } \\
\text { regeneração natural, controle de } \\
\text { competidores, adensamento e } \\
\text { enriquecimento }\end{array}$ \\
\hline Capoeira & Alto & Baixa & $\begin{array}{l}\text { Indução do banco, condução da } \\
\text { regeneração natural e } \\
\text { enriquecimento }\end{array}$ \\
\hline Floresta & Alto & Não & $\begin{array}{l}\text { Possível enriquecimento } \\
\text { (facultativo) }\end{array}$ \\
\hline
\end{tabular}


O solo sem vegetação, por não apresentar banco de sementes e não possuir cobertura vegetal foi à situação ideal para a transferência de banco de sementes alóctone, disponível pela abertura da cava da Mina Limeira, na CCRG.

As áreas de pasto sem regeneração natural, além de não terem apresentado banco de sementes de espécies nativas, ainda apresentaram a cobertura do solo com braquiária. Nesta situação a probabilidade de regeneração natural é bastante remota, mesmo próximo a remanescentes florestais que poderiam estar dispersando essas sementes. Áreas em restauração onde não há presença de banco de sementes nem indivíduos regenerantes, o plantio de espécies pioneiras e não pioneiras deve dar início ao processo de sucessão (Kageyama et al., 1989). Em função disso, a implantação total com controle intenso dos competidores é o método mais recomendado nesse caso. Também seria interessante testar o uso da transferência de banco de sementes alóctone com um controle prévio da braquiária através da aplicação de herbicidas pré e pós-emergentes ou ainda uma semeadura direta após a reversão do solo pelo arado.

Entretanto, nas situações de pasto com regeneração arbustiva e pasto com regeneração arbórea, pela densidade de indivíduos regenerados do banco, a indução da regeneração por meio do revolvimento do solo, poderá acelerar os processos de sucessão, possibilitando a germinação das sementes nativas e a competição pelo estabelecimento no local. Vale ressaltar que esta atividade também irá estimular a germinação das sementes de braquiária, dificultando bastante o estabelecimento de espécies nativas. Na prática temos observado que algumas espécies como a maria-mole (Senecio brasiliensis (Spreng.) Less.), conseguem se desenvolver no meio da braquiária, contribuindo com sombreamento e melhoria do ambiente, facilitando os processos de sucessão, embora isso ocorra muitas vezes de uma forma mais vagarosa.

Mesmo no caso da situação de pasto com regeneração arbustiva, que apresentou quase a sua totalidade de sementes pertencentes à forma de vida arbustiva, a regeneração irá colaborar para o sombreamento da área e conseqüentemente controle de espécies invasoras. Deixando o ambiente mais favorável para a introdução e desenvolvimento de espécies arbóreas, seja ele por meio da chuva de sementes ou mesmo plantio com implantação total. 
Para as situações de pasto com regeneração arbórea, o adensamento com mudas do estágio inicial de sucessão também deve ser usado em casos onde a regeneração natural não recobriu a área de modo satisfatório, visando o controle das espécies exóticas agressivas e a proteção do solo.

Além da utilização destas espécies de rápido crescimento e boa cobertura, também se recomenda fazer o plantio de enriquecimento na área, uma vez que o número de espécies encontradas no banco foi muito baixo (9 espécies) em comparação com o exigido na legislação, que define o mínimo de 80 espécies. O enriquecimento representa a introdução de espécies que não foram encontradas entre os indivíduos remanescentes ou germinados do banco de sementes da área que está sendo recuperada. Dessa forma, essa introdução de espécies é desejável para garantir a restauração dos processos ecológicos, possibilitando a sucessão percorrer vários caminhos alternativos para chegar ao clímax (Pickett et al., 1992).

Para a situação de capoeira, a indução do banco deve ser realizada em locais mais abertos, com boa luminosidade (clareiras), já que as espécies pioneiras, contidas no banco, dependem da luz para sua germinação e sobrevivência. Juntamente com essa atividade, pode ser realizado o controle de espécies invasoras e um enriquecimento, caso essa situação apresente um número baixo de espécies.

As áreas identificadas na Fazenda como situação de floresta entraram dentro do plano de restauração da Fazenda Intermontes apenas com ações de isolamento e retirada de fatores de degradação, uma vez que estas já se encontravam num estado relativamente avançado de conservação, onde a restauração dos processos ecológicos provavelmente já foi estabelecida.

\subsection{Conclusões}

- As situações ambientais identificadas apresentaram diferentes expressões de regeneração natural em função do número de indivíduos de espécies arbustivo-arbóreas germinados banco de sementes autóctone. O aproveitamento dessas sementes contidas 
no banco poderá ser efetivado através de metodologias diferenciadas de restauração para cada situação estudada, que promovam a indução da germinação dessas sementes e a condução dos indivíduos germinados, aumentando ou diminuindo as chances de estabelecimento efetivo das espécies nativas regenerantes.

- As densidades de indivíduos de espécies arbustivo-arbóreas germinados nas diferentes situações estudadas apresentaram-se com valores muito superiores aos de indivíduos adultos já estabelecidos em uma floresta conservada.

- A maior densidade de indivíduos de espécies arbustivo-arbóreas germinados foi da situação de floresta, que apresentou o número estimado de 690.000 indivíduos/ha (69,0 indivíduos $/ \mathrm{m}^{2}$ ). As outras situações de pasto com regeneração arbustiva, pasto com regeneração arbórea e capoeira apresentaram $42.500\left(4,2\right.$ indivíduos $\left./ \mathrm{m}^{2}\right), 67.500(6,8$ indivíduos $\left./ \mathrm{m}^{2}\right)$ e 472.500 indivíduos $/$ ha $\left(47,3\right.$ indivíduos $\left./ \mathrm{m}^{2}\right)$, respectivamente. A situação de pasto sem regeneração natural, não apresentou banco de sementes de indivíduos de espécies arbustivo-arbóreas.

- As fisionomias de capoeira e floresta apresentaram as maiores riquezas em espécies germinadas a partir do banco de sementes, sendo 11 e 9 espécies arbustivo-arbóreas, respectivamente em cada uma dessas situações. Do total de espécies germinadas, 2 foram classificadas como arbustivas.

- Todas as 11 espécies germinadas do banco de sementes pertencem ao grupo ecológico das pioneiras, as quais terão como função principal a rápida cobertura das áreas em processo de restauração, com possível enriquecimento futuro de espécies finais de sucessão, caso essas não surjam espontaneamente na área de restauração trazidas por dispersores, oriundos dos fragmentos remanescentes no entorno.

- Três, das seis situações identificadas no Zoneamento Ambiental da fazenda Intermontes, permitiram definir metodologia de restauração que aproveitassem o banco de sementes autóctone como uma das atividades de restauração: 1) pasto com regeneração arbustiva; 2) pasto com regeneração arbórea e; 3) capoeira. Entretanto, o sucesso desta atividade está diretamente vinculados às manutenções dessas áreas em processo de restauração, principalmente nas atividades de controle de competidores para as situações onde a fisionomia predominante é o pasto. 
- Os resultados da germinação do banco de sementes autóctone mostraram que presença de indivíduos de espécies arbustivo-arbóreas regenerantes, na área a ser restaurada, está relacionada à presença de banco de sementes da mesma forma de vida. 


\section{O USO DO BANCO DE SEMENTES ALÓCTONE COMO METODOLOGIA DE RECUPERAÇÃO DE ÁREAS DEGRADADAS}

Resumo

A possibilidade do uso de banco de sementes alóctone como metodologia de recuperação deverá reduzir os custos atuais de restauração, uma vez que, serão eliminadas as etapas intermediárias como a produção de mudas em viveiro, transporte das mudas para o campo, etc. Este trabalho estuda a metodologia de restauração usando banco de sementes alóctone e incorporando principalmente a idéia de restauração das funções do ambiente e dos processos ecológicos envolvidos. O experimento foi montado retirando-se o solo de três parcelas (repetições A, B e C) de 15 x $15 \mathrm{~m}$ e $10 \mathrm{~cm}$ de profundidade, de uma área florestal. O material recolhido nas três parcelas foi levado para a Fazenda Intermontes onde foi distribuído em área experimental, durante o início de fevereiro de 2003. Toda a área experimental ficou exposta às condições climáticas naturais do local. Após a segunda medição, o experimento recebeu durante os meses de março, abril e maio de 2004, uma adubação de NPK 20-00-20, na quantia de $25 \mathrm{gr} / \mathrm{m}^{2}$, em 50 \% de sua área. A amostragem da regeneração do banco de sementes alóctone em cada repetição do experimento foi realizada usando 15 subparcelas de $1 \mathrm{~m}^{2}$, dispostas aleatoriamente dentro de cada uma das parcelas. Os levantamentos foram realizados em março de 2003, março de 2004 e setembro de 2004, sendo a primeira medição realizada 1 mês após a implantação do experimento. A densidade dos indivíduos germinados se mostrou bastante elevada, com aproximadamente 409.334 indivíduos/ha. Foi constatada uma baixa riqueza de espécies arbustivo-arbóreas entre os indivíduos regenerantes, sendo apresentadas 5 espécies na primeira amostragem, 12 na segunda e 13 na terceira. 
No total das 18 espécies identificadas, 14 (77,8\%) foram classificadas como pioneiras e $4(22,2 \%)$ classificadas como não-pioneiras. Quanto a síndrome de dispersão das espécies regeneradas do banco de sementes alóctone, 4 (22,2 \%) das espécies amostradas são anemocóricas, $12(66,7 \%)$ são dispersas zoocóricas e $2(11,1 \%)$ são autocóricas. Após a adubação, os indivíduos arbóreos apresentaram na área adubada um acréscimo de 137,3 \% em sua altura média em relação aos indivíduos da área não adubada, passando de $15,23 \mathrm{~cm}$ para $36,14 \mathrm{~cm}$.

Summary

The possibility of allochthonous seed bank use as a restoration methodology shall reduce its actual costs, since intermediate steps like nursery plant production, seedlings transport to the field, etc. might be dismissed. This study presents the usage of allochthonous seed bank on restoration methodology, working with the idea of restoring environmental functions and ecological processes involved. The field experiment was conducted by withdrawing soil from three plots (trials A, B and C) with $15 \times 15 \mathrm{~m}$ and $10 \mathrm{~cm}$ depth in a woodland area. Material collected from these plots was taken to Intermontes farm, where it was distributed on an experimental area by February 2003. The experimental area was exposed to all local weather conditions. During March, April and May 2004, $50 \%$ of it was fertilized with $25 \mathrm{gr} / \mathrm{m}^{2}$ of NPK 20-00-20. Regenerating samples from allochthonous seed bank were taken by using 15 subplots of $1 \mathrm{~m}^{2}$, randomly located at each plot. Data was collected during March 2003, March 2004 and September 2004, being the first measurement taken one month after the experiment was established. Germinated individuals density was high, approximately 409.334 ind./ha. Low richness among regenerating individuals was detected for woody species, with only 5 species at the first sampling, 12 at the second and 13 at the third. From the 18 identified species, $14(77,8 \%)$ were classified as pioneers and $4(22,2 \%)$ as nonpioneers. Regarding dispersal syndrome, 4 (22,2\%) were anemochoric, 12 (66,7\%) zoochoric and $2(11,1 \%)$ autochoric. After fertilizing treatment, woody individuals at 
fertilized spot showed a mean height enhancement of $137,3 \%$ compared to those at the non-fertilized spot, growing from $15,23 \mathrm{~cm}$ to $36,14 \mathrm{~cm}$.

\subsection{Introdução}

O aproveitamento da camada superficial do solo em locais que serão desmatados ou desflorestados, visando sua utilização em projetos de recuperação, já é prática utilizada há bastante tempo por empresas mineradoras. No entanto, a utilização desta camada visando o uso do banco de sementes florestais presente no solo e na serapilheira dessas áreas que serão desmatadas ainda foi pouco estudada até o momento (Pederson \& Van der Valk, 1989; Skoglund, 1992; Gisler, 1995; Almeida-Cortez, 2004).

A técnica pode ser usada de forma mitigadora de impactos gerados por empreendimentos que tem como prática o decapeamento de áreas florestais nativas como, por exemplo, minerações, construções de rodovias, hidrelétricas, etc. (Van Der Valk, 1989; Skoglund, 1992; Rodrigues \& Gandolfi, 1996; Rodrigues \& Gandolfi, 2004). As ações mitigadoras podem ser realizadas através da preservação não só da camada mais fértil do solo, mas também, de todo o material genético presente no mesmo que se perderia caso este fosse destinado a um aterro sem posterior utilização (Rodrigues \& Gandolfi, 2004).

Dessa forma, ao transportarmos a camada superficial do solo oriundo de florestas, estamos levando junto, um banco de sementes contendo diferentes formas de vidas como espécies arbóreas, herbáceas, arbustivas, lianas, além de outras formas de vida como a micro fauna, fungos, bactérias, etc (Rodrigues et al., 2004b).

As sementes presentes nos solos das florestas tropicais podem ser uma fonte importante de recrutamento de indivíduos regenerantes após perturbações, influenciando a regeneração da floresta bem como a sucessão secundária (Grombone \& Rodrigues, 2002; Almeida-Cortez, 2004). As sementes disponíveis numa área, vindas de chuva de sementes ou presentes no banco, podem fornecer indicativos importantes sobre a capacidade de regeneração natural (Siqueira, 2002). 
Por outro lado, existem muitas áreas degradadas cuja camada superficial do solo foi perdida, deixando aflorar as camadas mais profundas e pobres do solo. Essa situação é bastante comum em áreas onde houve corte e aterro do solo para construção de estradas, terraplanagem, retirada de cascalho, etc. Essas áreas necessitam inicialmente da recuperação do solo para que possam fornecer os recursos necessários para o estabelecimento de uma cobertura vegetal natural.

Assim, a transferência do banco de sementes alóctone para esses locais de extrema degradação, leva junto as camadas superficiais do solo e a serapilheira, ricas em nutrientes e contendo uma microfauna associada, que irão melhorar as condições físicas e químicas do solo.

Essas ações, aliadas ao resgate de indivíduos regenerantes da flora (banco de plântulas e indivíduos jovens), as quais devem anteceder o resgate do banco de sementes, vêm ganhando cada vez mais destaque nos projetos de recuperação ambiental, sempre com o objetivo de mitigar os impactos gerados pelo homem (Rodrigues \& Gandolfi, 2004).

Atualmente, alguns métodos de reflorestamento usando a semeadura direta, que na verdade é a construção de um banco de sementes artificial, estão sendo testados para recuperação de áreas degradadas (Araki \& Rodrigues, 2003). A viabilização do uso de semeadura direta e/ou banco de sementes alóctone como metodologias de recuperação de áreas degradadas deverá reduzir significativamente os custos atuais de restauração, uma vez que serão eliminadas as etapas intermediárias como a produção de mudas em viveiro, transporte das mudas para o campo, etc. (Rodrigues \& Gandolfi, 2004).

Vale lembrar que, as metodologias de restauração usando banco de sementes e de plântulas só ganharam força nos últimos anos com a introdução de conceitos baseados no Paradigma Contemporâneo. Dentro desses conceitos é aceita a teoria de que as mudanças sucessionais da vegetação podem ocorrer seguindo múltiplas trajetórias (Pickettet al., 1992), não existindo uma convergência nas mudanças do sistema para chegar a um clímax único. No Paradigma Clássico da ecologia, essas metodologias não eram bem aceitas, uma vez que se buscava um modelo ideal de floresta com um clímax único. Isso só podia ser reproduzido por meios onde se controlava as espécies e o 
número de indivíduos que fariam parte da composição final da floresta restaurada (Rodrigues et al., 2004b).

O mais importante na Concepção Contemporânea é a recuperação da integridade ecológica dos ecossistemas, considerando um "mínimo" de biodiversidade e de variabilidade na estrutura e no funcionamento dos processos ecológicos e incorporando seus valores ecológicos, econômicos e sociais ("Society for Ecological Restoration").

Dentro deste contexto e de acordo com o Paradigma Contemporâneo, são necessárias três premissas básicas para que ocorram os processos de sucessão em uma área a ser restaurada: a) Disponibilidade de local adequado; b) Disponibilidade de diferentes espécies; c) Disponibilidade de diferentes performances entre as espécies (Pickett et al., 1987).

Deve ficar claro que o banco de sementes alóctone irá contribuir apenas parcialmente dentro das premissas estabelecidas por Pickett et al. (1987). Já é conhecido que a contribuição do banco de sementes na regeneração é apenas em termos de grupos ecológicos (Baider et al., 2001), sem restabelecer a riqueza de espécies, uma vez que poucas espécies permanecem ativas no banco de sementes (Holthuijen \& Boerboom, 1982; Garwood, 1989; Grombone \& Rodrigues, 2002; Almeida-Cortez, 2004). Em função disso, deve se esperar que o grupo de espécies regenerantes do banco de sementes, na maioria pioneiras, atue como "cicatrizador" do ambiente (Denslow \& Gómez Dias, 1990; Martinez Ramoz \& Soto-Castro, 1993) e com isso, promovam mudanças das condições edáficas e microclimáticas, criando condições para a chegada e desenvolvimento de outras espécies, seja por dispersão ou até mesmo por atividades de enriquecimento (Rodrigues \& Gandolfi, 2004).

É neste sentido que este trabalho estuda a metodologia de restauração usando banco de sementes alóctone e incorporando principalmente a idéia de restauração das funções do ambiente e dos processos ecológicos envolvidos, aumentando com isso, as chances de perpetuação do sistema, independente do clímax final alcançado (Pickettet al., 1992). 
Dentro deste contexto, este trabalho busca responder algumas questões: a) qual a densidade de indivíduos e número de espécies arbóreas regeneradas do banco de sementes alóctone? b) existe a necessidade de um enriquecimento futuro destas áreas recuperadas com o banco de sementes alóctone? c) qual é o grupo ecológico e a síndrome de dispersão predominante entre os indivíduos regenerados do banco de sementes alóctone? d) a adubação pode colaborar para o efetivo estabelecimento dos indivíduos resgatados do banco de sementes alóctone?

\subsection{Material e Métodos}

\subsection{1 Área estudada}

Este trabalho foi desenvolvido na Companhia de Cimento Ribeirão Grande (CCRG), distante aproximadamente 12,5 km ao sul do município de Ribeirão Grande, SP e cerca de $250 \mathrm{~km}$ da cidade de São Paulo (Figura 1). A empresa tem como atividade mineraria a exploração de metacalcários e argila para produção de cimento.

Com a autorização do DEPRN em 08/02/2001 para o corte da vegetação na Mina Limeira, o Laboratório de Ecologia e Restauração Florestal (LERF) foi convidado a participar das atividades mitigadoras. Diante da oportunidade de estudo sobre o aproveitamento dos propágulos que seriam suprimidos, o LERF propôs o resgate e uso do banco de sementes alóctone como uma das medidas mitigadoras do impacto gerado pelo empreendimento. 


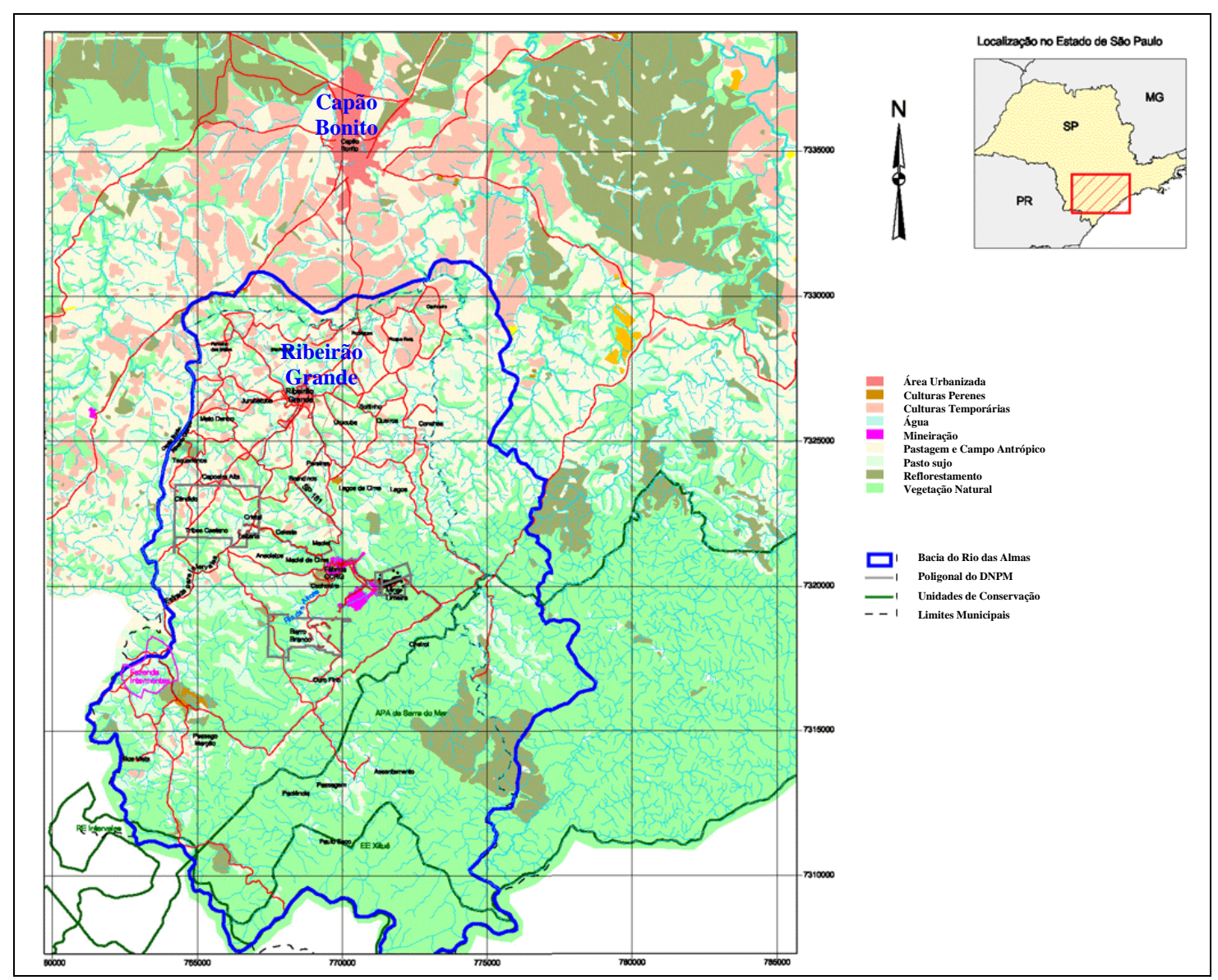

Figura 1 - Localização da Região do município de Ribeirão Grande e da Cia de Cimento Ribeirão Grande no Estado de São Paulo

A camada superficial do solo contendo o banco de sementes alóctone foi retirada da Mina Limeira, localizada a cerca de $3 \mathrm{~km}$ da fábrica da empresa e transportada para área experimental na Fazenda Intermontes, também pertencente a CCRG (Figura 2, 3 e 4). A Fazenda possui 343 ha na sua escritura e está localizada na estrada que liga o município de Ribeirão Grande ao Parque Estadual de Intervales, distante aproximadamente $17 \mathrm{~km}$ ao sul do Município de Ribeirão Grande. Sua localização geográfica está inserida entre as coordenadas UTM 7.322.500 N; 762.750 L e 7.319.800 $\mathrm{N} ; 760.250 \mathrm{~L}$. 
Essa atividade de restauração usando o banco de sementes alóctone deu origem a esse trabalho que visa o desenvolvimento de novas metodologias para subsidiar as futuras atividades de restauração florestal.

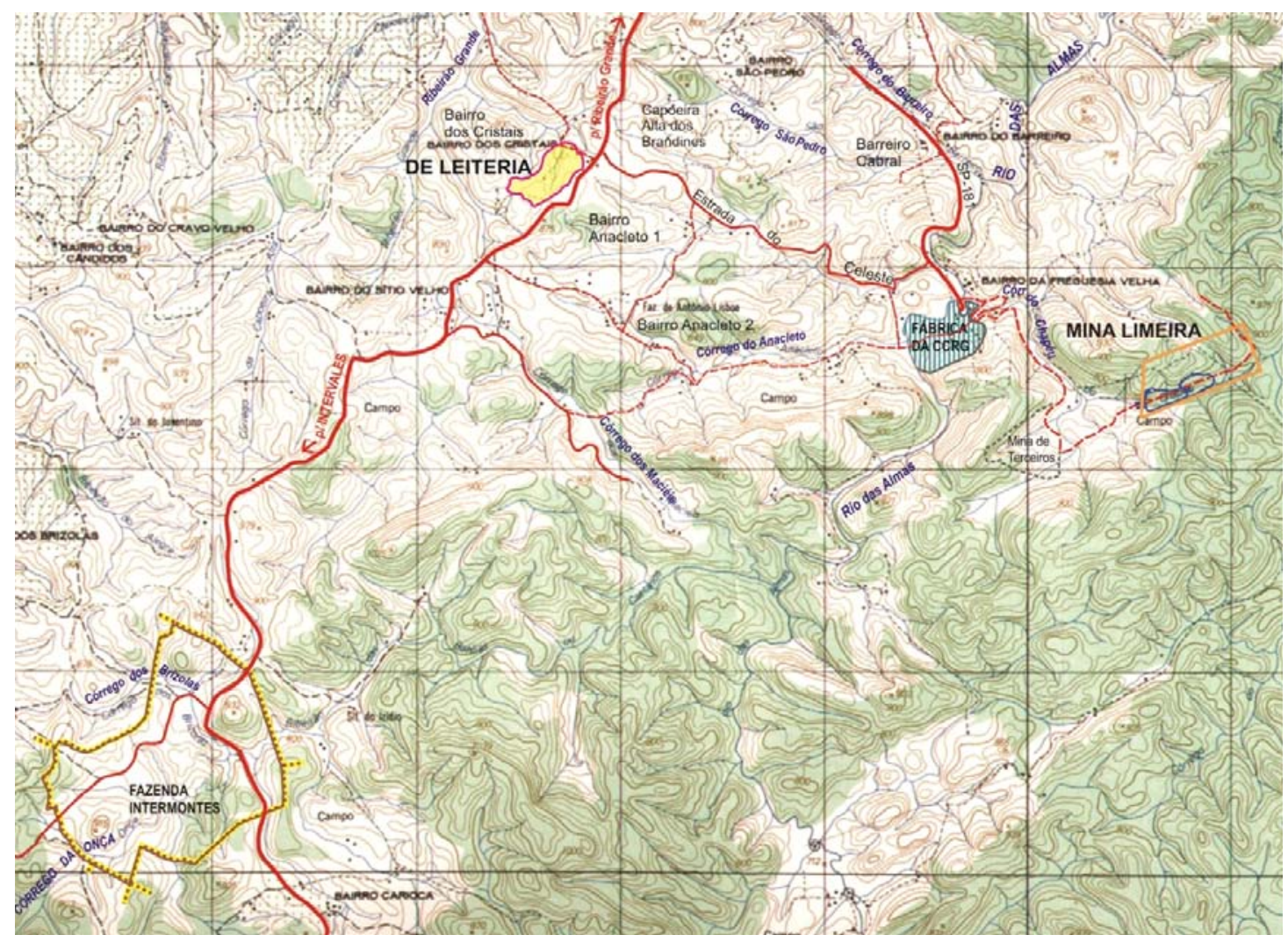

Figura 2 - Croqui de localização com a localização da Mina Limeira (área de origem do banco de sementes alóctone) e Fazenda Intermontes (área de depósito do banco de sementes), pertencentes à CCRG, município de Ribeirão Grande, SP 


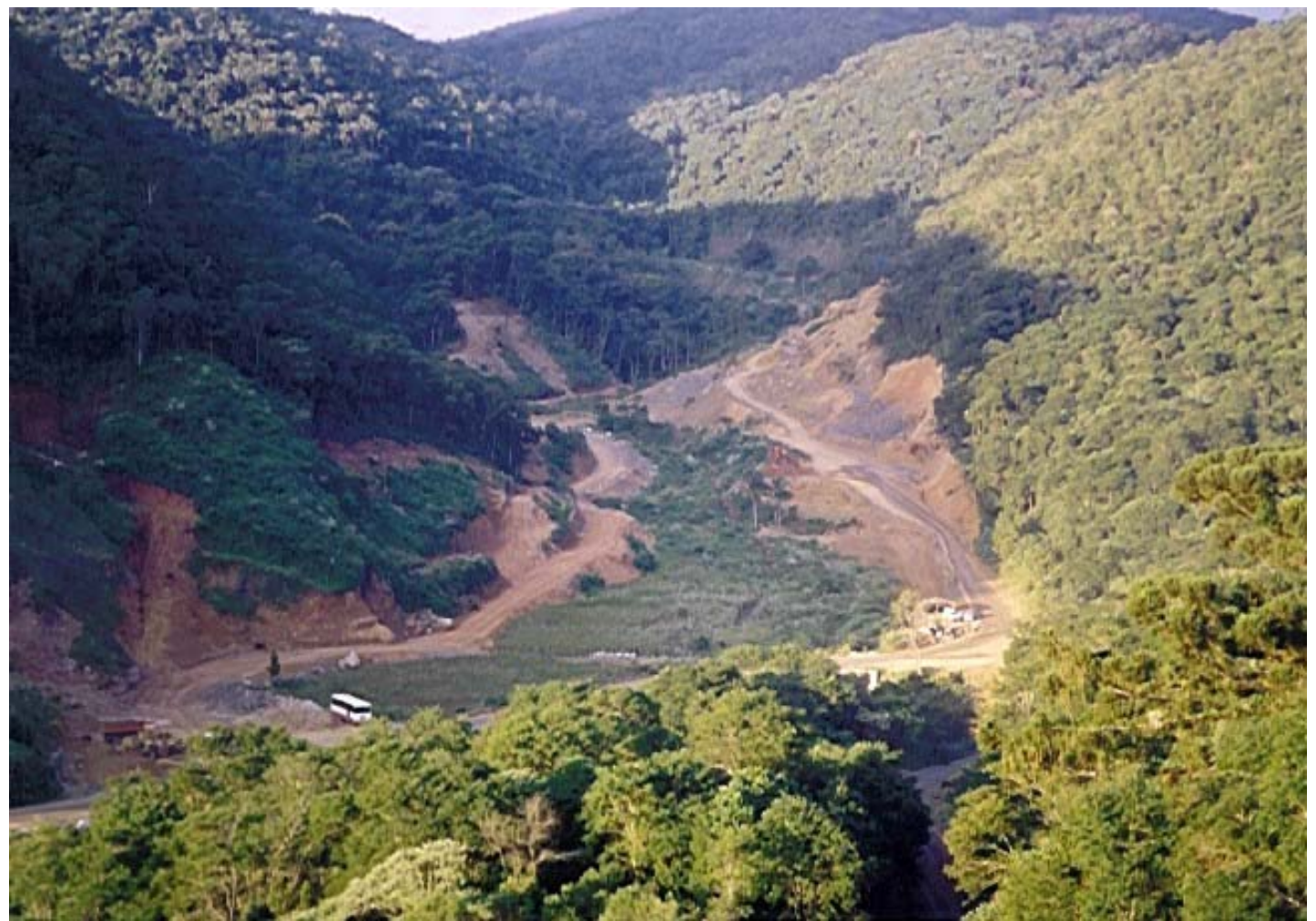

Figura 3 - Vista geral da Mina Limeira no início das atividades minerarias (2001) e vegetação do entorno onde foi resgatado o banco de sementes alóctone, CCRG, município de Ribeirão Grande, SP

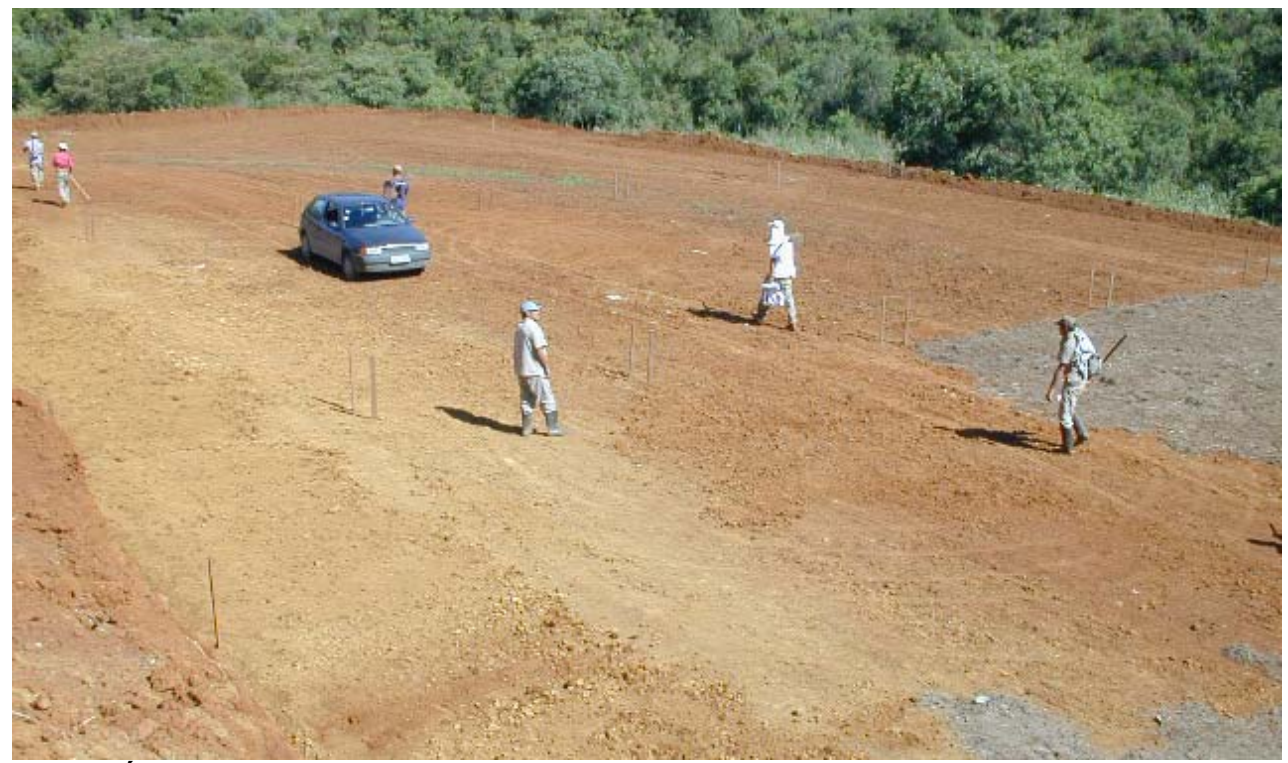

Figura 4 - Área experimental na Fazenda Intermontes onde foi depositado o banco de sementes alóctone, CCRG, município de Ribeirão Grande, SP 
A região do estudo está inserida na Província Geomorfológica do Planalto Atlântico, Zona do Planalto de Guapiara, que compreende a região elevada do alto da Serra de Paranapiacaba e estende-se até a cobertura sedimentar da bacia do Paraná. É uma região que comporta os afluentes de alto curso da margem esquerda do Paranapanema, cuja borda sul marca o divisor de águas da drenagem continental (Vale do Paranapanema) e da litorânea (Vale do Ribeira) (CCRG, 2003).

A declividade dominante está entre 20 a $30 \%$, onde os fundos dos vales estão acima de $800 \mathrm{~m}$ de altitude e os espigões muitas vezes ultrapassam $1.000 \mathrm{~m}$ de altitude (CCRG, 2003).

Essas características definem para região, segundo a classificação de Köeppen (1948), o clima temperado úmido sem estiagem (Cfb), que ocupa áreas do Planalto de Guapiara com altitudes superiores a $800 \mathrm{~m}$. Nessa parte mais alta da Serra de Paranapiacaba as temperaturas médias são inferiores a $18^{\circ} \mathrm{C}$ no mês mais frio e inferiores a $22^{\circ} \mathrm{C}$ no mês mais quente (Nimer, 1989; Setzer, 1966).

A Mina Limeira está situada na bacia hidrográfica do Córrego do Chapéu, afluente da margem direita do Rio das Almas, que é um dos afluentes da margem direita do Rio Paranapanema. A precipitação média da bacia do Córrego do Chapéu é de 1300 $\mathrm{mm}$, variando de 1.100 e $1.500 \mathrm{~mm}$ por ano, com chuvas concentradas no verão, principalmente nos meses de dezembro, janeiro e fevereiro. Nessa região o período correspondente ao inverno é o que apresenta a maior redução dos índices pluviométricos. O total pluviométrico do mês mais seco é superior a $30 \mathrm{~mm}$ (CCRG, 2003). As temperaturas mínimas absolutas anuais chegam a $-4^{\circ} \mathrm{C}$, nas altitudes mais elevadas, ocorrendo em média de um a cinco dias de geadas por ano (Nimer, 1989; Setzer, 1966). 


\subsubsection{A vegetação regional}

A vegetação do município de Ribeirão Grande localiza-se no Planalto Atlântico do Estado de São Paulo, na divisa com a Província Costeira, próxima a escarpa do Planalto Atlântico, onde predomina a Floresta Estacional Semidecidual, mas devido à proximidade com a Serra de Paranapiacaba, apresenta muitas espécies típicas da Floresta Ombrófila Densa na composição florística local (CCRG, 2003).

A flora regional tem contribuições de várias formações, na região do Parque Estadual de Intervales ocorrem as chamadas Florestas Ombrófilas, por desenvolveremse em clima úmido sem período de estiagem (Mantovani, 1994). No reverso da Serra de Paranapiacaba, estende-se até Capão Bonito, o estremo norte do domínio da Floresta de Araucárias, formação dos climas temperados quentes e úmidos ou subtropicais úmidos do Sul do Brasil (Klein, 1984). Nas drenagens do Vale do Paranapanema, provavelmente, originam-se as espécies típicas de Floresta Estacional Semidecidual do interior dos Estados de São Paulo, Paraná e Minas Gerais (Mantovani, 1994).

As florestas da região encontram-se em estádios diferenciados de sucessão, resultado de ocupação para prática de agricultura por períodos variáveis e pela extração seletiva de madeira e do palmiteiro (Mantovani, 1994). Geralmente os trechos florestais bem conservados encontram-se nas encostas mais íngremes ou em locais de difícil acesso.

\subsubsection{Montagem do experimento}

Foram alocadas aleatoriamente 3 parcelas (repetições A, B e C) de 15 x 15 m no fragmento florestal remanescente localizado na Mina Limeira em um trecho que será deflorestado pela ação minerária (Figura 3), totalizando 67,7 ha. A área se encontra sob as coordenadas UTM: $0772102 \mathrm{~N}$ e 7324868 L; $0771268 \mathrm{~N}$ e 7324530 L; $0771449 \mathrm{~N}$ e 7324618 L, respectivamente. Deste trecho de floresta, foram retiradas das 3 parcelas, uma camada de $10 \mathrm{~cm}$ de profundidade de solo, mais a serapilheira que tinha altura variada, resultando um volume aproximado de $22,5 \mathrm{~m}^{3}$ por parcela. Embora a literatura 
cite que cerca de $60 \%$ das sementes do banco encontram-se nos primeiros $2,5 \mathrm{~cm}$ de solo (Baider et. al., 2001), a profundidade de $10 \mathrm{~cm}$ de solo foi escolhida para tentar resgatar não só o máximo de sementes presentes no banco, mas também, os nutrientes contidos nesta camada mais fértil do solo (Gisler, 1995). O material recolhido nas 3 parcelas foi ensacado e levado para a Fazenda Intermontes, localizada aproximadamente a 12 quilômetros de distância da área fornecedora do banco de sementes, em área destinada a esse experimento cujas coordenadas são: UTM: 0761462 N e 7321934 L.

A área experimental foi previamente terraplanada e nos seus limites foram construídos drenos para que não houvesse risco do material ser levado por enxurradas ocasionais. Essa área experimental foi instalada com as dimensões de $30 \times 60 \mathrm{~m}$, onde foram montados 4 parcelas de $15 \times 30 \mathrm{~m}$ (Figura 5) para receber o material das 3 parcelas da Mina e mais uma testemunha. Entre as parcelas foi deixada uma faixa de 1 metro de largura.

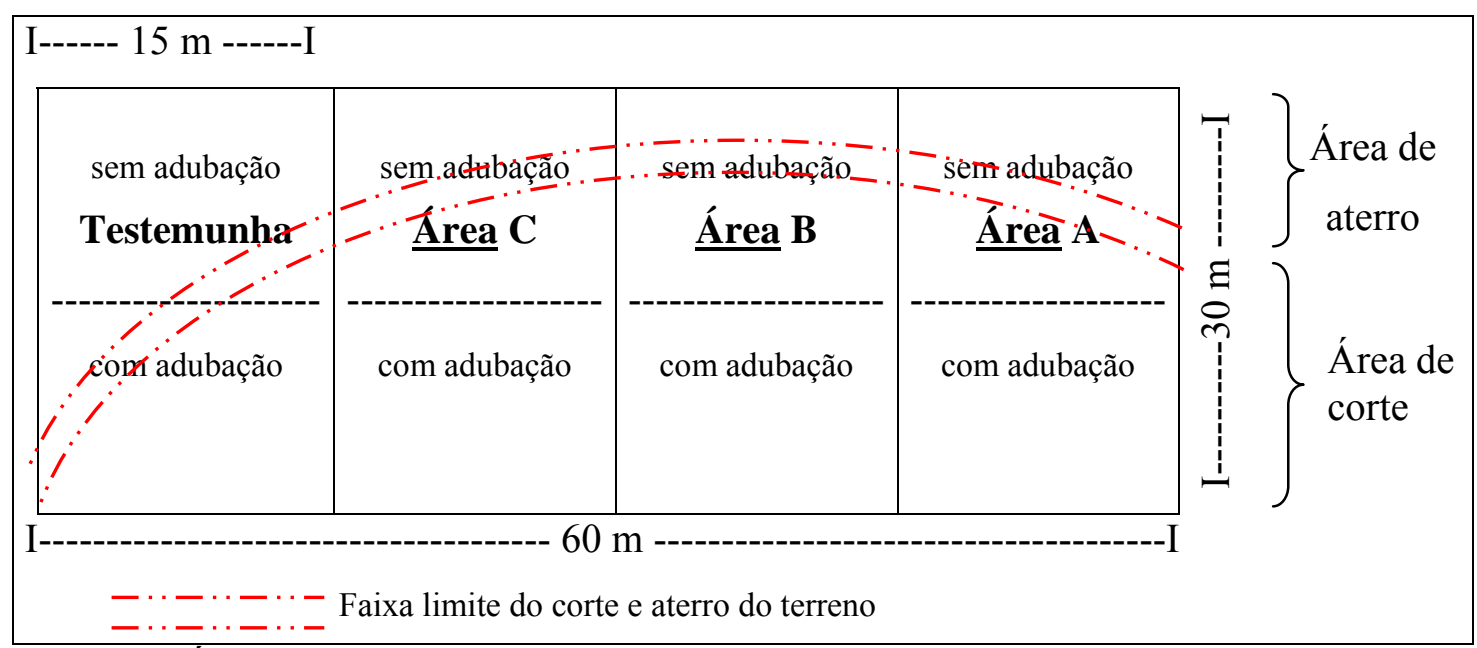

Figura 5 - Área experimental contendo o banco de sementes alóctone e área de adubação (realizada entre a segunda e terceira amostragem), Fazenda Intermontes CCRG, município de Ribeirão Grande, SP

Três parcelas receberam, no início de fevereiro de 2003, uma camada de aproximadamente $5 \mathrm{~cm}$ de altura do material contendo o banco de sementes e a serapilheira (Figuras 6 e 7). Essa camada foi definida visando o máximo de exposição de 
sementes a luz, mas ao mesmo tempo a permanência dos propágulos no local, já que, camadas mais finas teriam maiores riscos de serem carregadas pelo escoamento superficial ocasionado por fortes chuvas. Outro motivo foi à possibilidade de fornecimento de nutrientes contidos no solo e na serapilheira, carregados juntamente com o banco de sementes alóctone, uma vez que, camadas mais expessas de solo poderiam fornecer uma quantidade maior de nutrientes para os indivíduos regenerantes, mesmo porque o experimento foi implantado em área terraplanada, com baixa disponibilidade de nutrientes.

O material contendo o banco de sementes espalhado num período inferior a 48 horas. Uma parcela da área experimental foi usada como testemunha (Figura 5). Toda a área experimental ficou exposta às condições climáticas típicas do local, sem nenhuma proteção específica, sendo esse, o único tratamento até a segunda medição. Após a segunda medição, o experimento recebeu durante os meses de março, abril e maio de 2004, uma adubação de NPK de formulação 20-00-20, na quantia de $25 \mathrm{gr} / \mathrm{m}^{2}$, em $50 \%$ de sua área, conforme mostra a Figura 5.

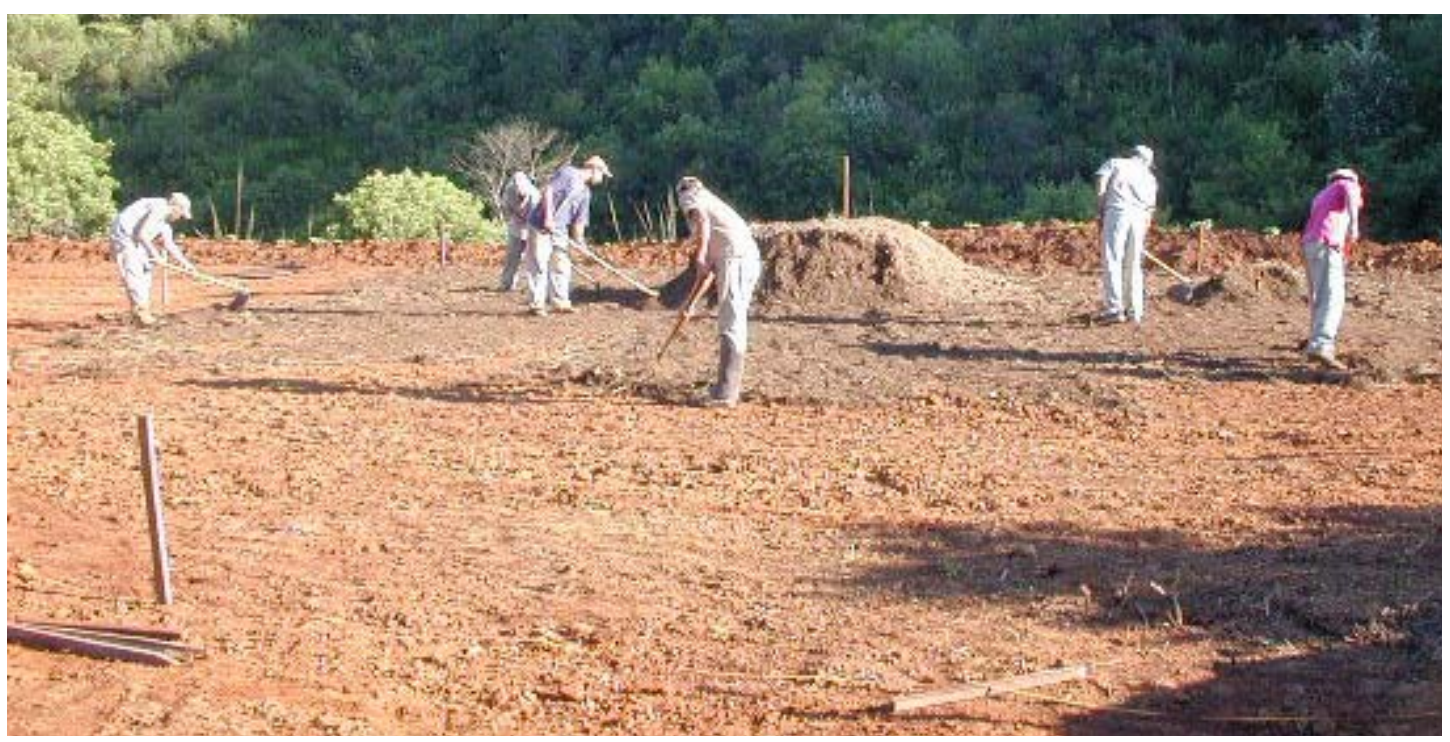

Figura 6 - Distribuição da serapilheira contendo o banco de sementes alóctone em fevereiro de 2003, Fazenda Intermontes, CCRG, município de Ribeirão Grande, SP 


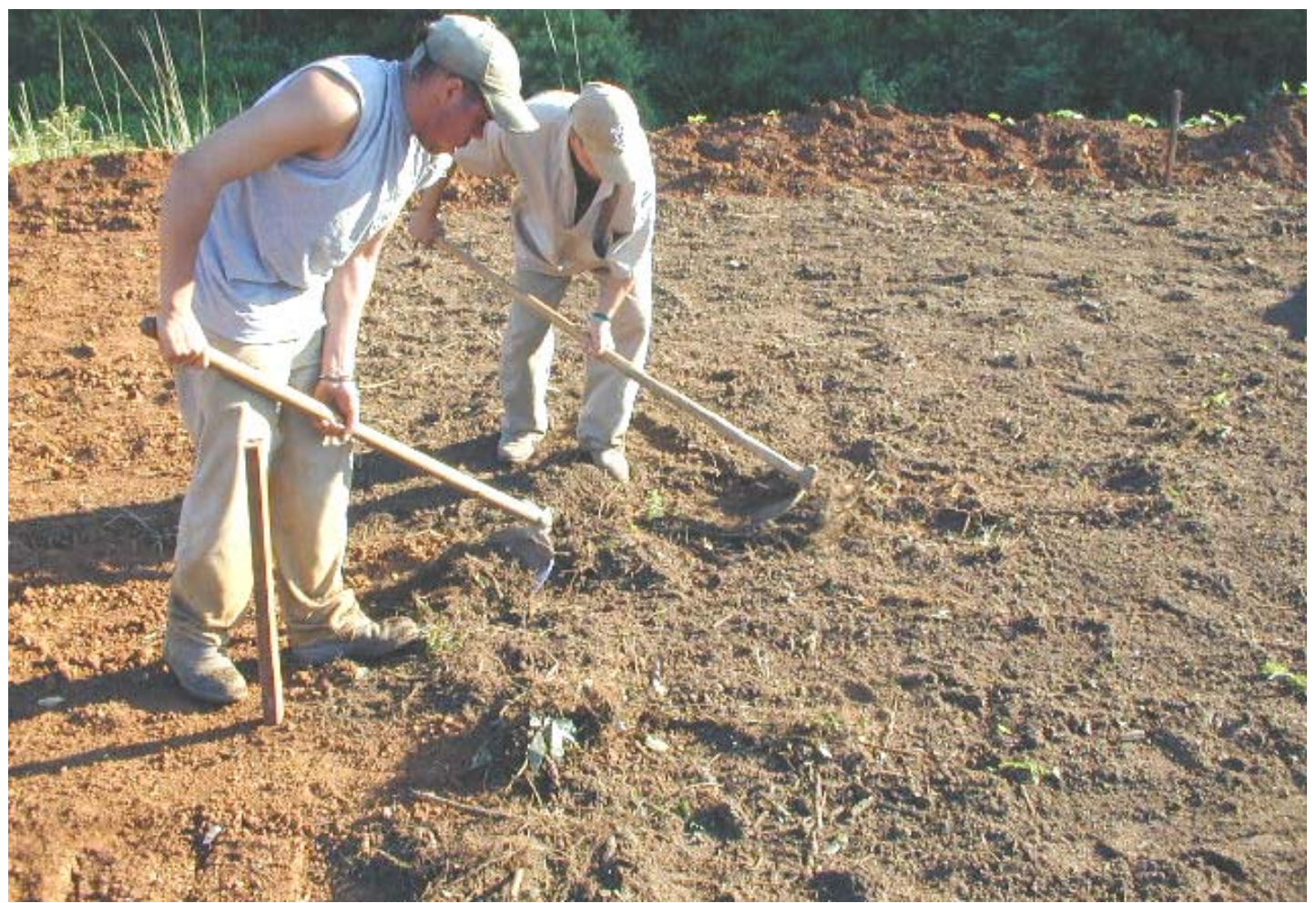

Figura 7 - Distribuição da serapilheira contendo o banco de sementes alóctone em fevereiro de 2003, Fazenda Intermontes, CCRG, município de Ribeirão Grande, SP

\subsubsection{Coleta de dados}

A amostragem da regeneração do banco de sementes alóctone em cada repetição do experimento foi realizada usando 15 subparcelas de $1 \mathrm{~m}^{2}$, dispostas aleatoriamente dentro de cada uma das parcelas (A, B, C + Testemunha), totalizando 60 subparcelas em cada amostragem. As 60 subparcelas foram sorteadas em cada uma das 3 amostragens, onde foram anotadas informações sobre o número de indivíduos e espécies regenerados do banco de sementes alóctone e altura desses indivíduos. A aleatoriedade das subparcelas foi obtida pelo sorteio de coordenadas X e Y, sendo os eixos representados no campo por linhas laterais e perpendiculares de cada um das parcelas.

Na primeira amostragem (após um mês), por se tratar de um banco de plântulas e indivíduos regenerantes, com tamanho bastante uniforme, a altura foi padronizada com o 
valor de $3 \mathrm{~cm}$, uma vez que, esse valor representava a média da altura dos indivíduos regenerados.

Os levantamentos foram realizados em março de 2003, março de 2004 e setembro de 2004, sendo a primeira medição realizada 1 mês após a implantação do experimento. A segunda e a terceira medição foram realizadas 13 meses e 19 meses, respectivamente, após a implantação, sendo que, nestas etapas finais, as alturas dos indivíduos também foram consideradas.

Durante a coleta de dados foi percebida uma diferença de desenvolvimento das mudas coincidindo com as áreas de corte e aterro do terreno, produzido em função do processo de terraplenagem, sendo que as plantas localizadas dentro da faixa limite, entre o corte e o aterro e na área de aterro (Figura 8), apresentavam-se visualmente com desenvolvimento superior às plantas localizadas na área de corte do terreno. Provavelmente isso ocorreu devido ao maior acúmulo de nutrientes nesse local onde a camada superficial do solo (mais rica em nutrientes) continuou exposta.

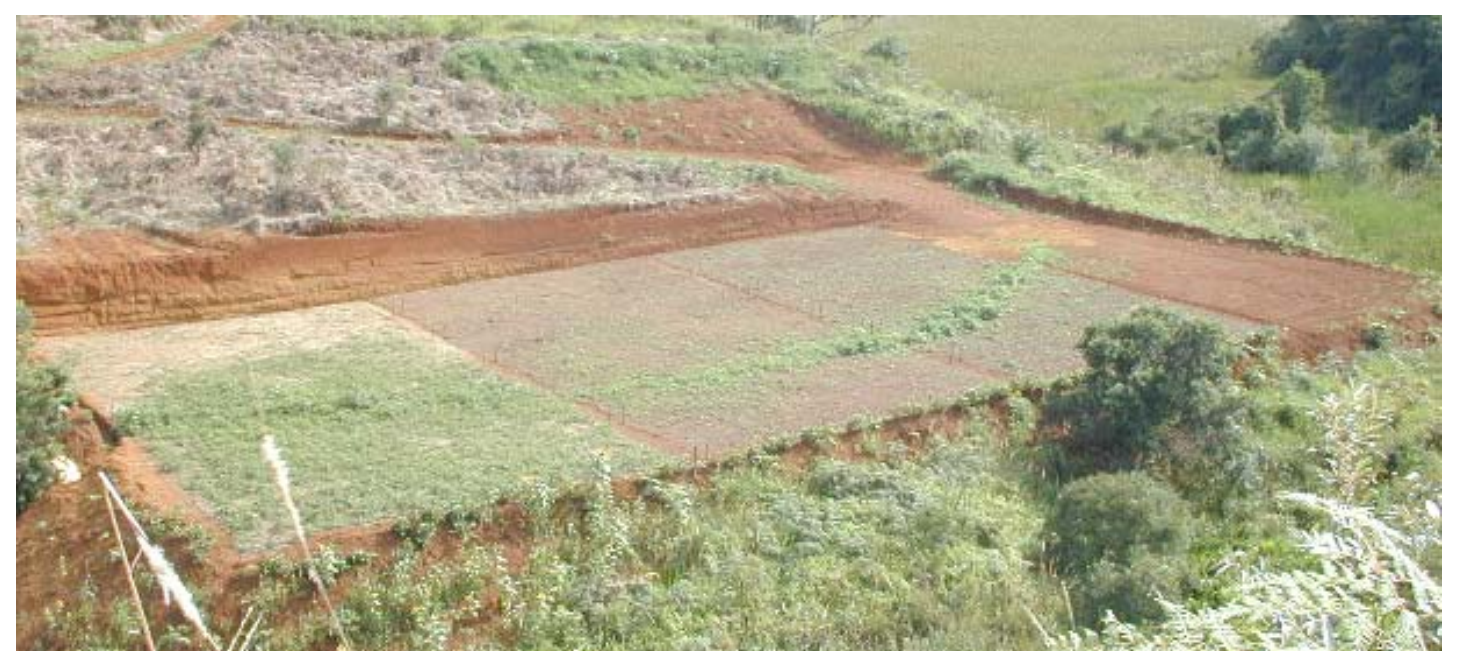

Figura 8 - Área onde foi realizado o experimento contendo o banco de sementes alóctone na Fazenda Intermontes, CCRG, município de Ribeirão Grande, SP. Detalhe do maior desenvolvimento das plantas na linha de corte e aterro

Em função disso, para comparação dos resultados da adubação, a área situada sobre a faixa limite entre o corte e o aterro e área do aterro do terreno, foram eliminadas da amostragem. Dessa forma, foram amostradas 22 subparcelas distribuídas em área de 
corte não adubada e mais 22 subparcelas distribuídas em área de corte adubada. Essa medida de eliminação de parcelas não foi realizada nas outras amostragens em que foram analisados apenas os números de indivíduos e espécies regenerantes.

As classes sucessionais (Budowski, 1965, Whitmore, 1982) das espécies regeneradas foi definida por meio do conceito de Pioneiras (agrupando as pioneiras e secundárias iniciais) e Não-pioneiras (agrupando as secundárias tardias e climácicas) (Kageyama \& Gandara, 2004), freqüentemente utilizado em trabalhos práticos de restauração.

Durante o trabalho de revisão bibliográfica foram observadas diferenças na classificação sucessional de algumas espécies por diferentes autores. A inexistência de um consenso entre os pesquisadores (Barbosa, 2004; Kageyama \& Gandara, 2004) fez com que fossem consultados vários trabalhos (Gandolfi, 1991, Gandolfi et al., 1995; Gabriel, 1997; Albuquerque, 1999; Fundação Florestal, 2004) e assumida a classificação em que a espécie predominava.

De acordo com a síndrome de dispersão, as espécies foram classificadas em autocóricas (frutos explosivos), anemocóricas (dispersas pelo vento) e zoocóricas (dispersas por animais) (Van Der Pijl, 1969). A identificação da síndrome de dispersão das espécies regenerantes foi baseada nos trabalhos de Carmo \& Morellato (2004), Toniato (2001), Souza (2002), Lorenzi (2002), Silva (2003) e Manhães (2003).

Quanto ao tamanho das sementes, estas foram classificadas em 3 grupos definidos neste trabalho de acordo com a quantidade de sementes por quilo: a) grandes, com até 2.000 sementes por quilo; b) médias, entre 2.001 e 10.000 sementes por quilo e; c) pequenas, acima de 10.001 sementes por quilo.

Para a colocação das espécies nas suas respectivas famílias botânicas foi usado o sistema de classificação APG II (Angiosperm Phylogeny Group - APG II, 2003), mais aceito atualmente entre a maioria dos pesquisadores da área. 


\subsubsection{Análises estatísticas}

As análises estatísticas foram realizadas visando a comparação dos resultados obtidos entre duas áreas, uma que recebeu adubação (A) e outra que não recebeu adubação (B).

A hipótese testada e de que os indivíduos de espécies arbustivo-arbóreas na área adubada apresentem um desenvolvimento maior que na área não adubada. Considerou-se haver um delineamento amostral no qual parcelas foram aleatoriamente distribuidas nas duas situações.

Como se deseja comparar 2 situações, foi aplicado um teste estatístico nãoparamétrico de Wilcoxon (Campos, 1983) com objetivo de comparar as alturas médias das duas condições estudadas, com e sem adubação.

Havendo indícios de diferença entre os dados, por aproximação de qui-quadrado do teste de Wilcoxon, foram feitas comparações entre as tendências centrais através da mediana.

Para esse estudo foi assumido um nível de significância de 5\%. Os dados foram processados no programa SAS (SAS Institute Inc., 1999).

\subsection{Resultados e Discussão}

Nos três levantamentos dos indivíduos regenerados do banco de sementes alóctone, foram amostrados 1.855 indivíduos de 5 espécies ( $1^{\circ}$ amostragem), 639 indivíduos de 12 espécies ( $2^{\circ}$ amostragem) e 456 indivíduos de 13 espécies (3º amostragem), totalizando 18 espécies diferentes em 14 famílias botânicas (Tabela 1).

A Tabela 1 mostra o elevado número de indivíduos regenerantes do banco de sementes alóctone. Isso ocorreu principalmente na primeira amostragem que apresentou a quantia média de 409.334 indivíduos/ha. Os números obtidos chamam a atenção para a grande expressão da regeneração do banco de sementes alóctone, mesmo porque, o solo contendo o banco de sementes foi retirado originalmente de uma área com a metade das 
dimensões usadas na área do experimento. Isso significa que provavelmente numa mesma área de onde foi retirado o solo contendo o banco de sementes alóctones, continha pelo menos o dobro do número de sementes que regeneraram na área experimental.

Tabela 1. Número de indivíduos de espécies arbustivo-arbóreas amostrados, densidade, número de espécies e altura média dos indivíduos germinados do banco de sementes alóctone na Fazenda Intermontes, CCRG, Ribeirão Grande, SP. Amostragens: $1^{\circ}$ ( 1 mês), $2^{\circ}(13$ meses $), 3^{\circ}$ (19 meses)

\begin{tabular}{|c|c|c|c|c|c|c|c|c|c|c|c|c|}
\hline \multirow[t]{2}{*}{ Parcelas } & \multicolumn{3}{|c|}{$\begin{array}{l}\mathrm{N}^{\circ} \text { ind. Amost. } \\
\left(15 \mathrm{~m}^{2}\right)\end{array}$} & \multicolumn{3}{|c|}{$\begin{array}{l}\text { Densidade média estimada } \\
\text { (ind./ha) }\end{array}$} & \multicolumn{3}{|c|}{ No de espécies } & \multicolumn{3}{|c|}{ Altura média (cm) } \\
\hline & $\mathbf{1}^{\mathbf{0}}$ & $2^{\mathbf{o}}$ & $3^{\circ}$ & $1^{0}$ & $2^{0}$ & $3^{\mathbf{o}}$ & $1^{\circ}$ & $2^{o}$ & $3^{\circ}$ & $1^{0}$ & $2^{\circ}$ & $3^{\circ}$ \\
\hline $\mathbf{A}$ & 462 & 271 & 194 & 308.000 & 180.668 & 129.334 & 4 & 7 & 8 & 3 & 22,5 & 36,6 \\
\hline B & 885 & 177 & 98 & 591.333 & 118.666 & 65.334 & 3 & 5 & 7 & 3 & 13,5 & 30,2 \\
\hline $\mathrm{C}$ & 508 & 191 & 164 & 328.667 & 127.333 & 109.335 & 3 & 8 & 9 & 3 & 19,8 & 29,7 \\
\hline $\mathbf{A}+\mathbf{B}+\mathbf{C}$ & 1855 & 639 & 456 & 409.334 & 142.223 & 101.334 & 5 & 12 & 13 & $3 *$ & 19,2 & 32,8 \\
\hline Testemunha & 0 & 0 & 0 & 0 & 0 & 0 & 0 & 0 & 0 & 0 & 0 & 0 \\
\hline
\end{tabular}

* - na primeira amostragem foram considerados $3 \mathrm{~cm}$ de altura para cada indivíduo amostrado por representar a média das plântulas recém germinadas

Esses valores são muito elevados, chegando a ser 200 vezes maior que o número de indivíduos adultos que provavelmente serão estabelecidos numa floresta madura, cujo valor médio é cerca de 2.000 indíviduos por hectare considerando Perimetro a Altura do Peito (PAP) $\geq 15$ cm (Mantovani et al., 1990; César \& Monteiro, 1995; Ivanauskas et al., 2001). Portanto, é esperado que as sementes, as plântulas ou indivíduos jovens sofram uma grande redução quantitativa, determinada pelos vários processos reguladores da dinâmica florestal, baixando sua densidade para um número de indivíduos semelhante a de uma área natural, quando estiverem adultos.

Esses números mostram também que, o material contendo o banco de sementes poderia ser depositado em camadas mais finas, desde que a metodologia de distribuição permitisse e não houvesse problemas de carreamento desse material no solo. Dessa forma, o material reprodutivo e genético contido no banco de sementes alóctone provavelmente poderia ser melhor aproveitado, diminuindo a densidade e a competição entre plântulas germinadas. 
Por outro lado, a competição é uma forma natural de seleção de indivíduos mais aptos, fazendo parte dos processos naturais de uma floresta. Na visão conceitual contemporânea, os eventos naturais como geadas, herbivoria, estiagem, etc., estariam atuando na seleção de indivíduos e com isso alterando os caminhos sucessionais em direção ao clímax (Pickett et al., 1992).

$\mathrm{Na}$ Tabela 1 pode ser percebido que a alta densidade de indivíduos constatada na primeira amostragem (1.855 ind.) caiu drasticamente nas amostragens subseqüentes, sendo que o valor encontrado na segunda amostragem corresponde a 34,5\% (639 ind.) do valor da primeira e o valor encontrado na terceira amostragem corresponde a $24,6 \%$ (456 ind.) do valor da primeira. Durante o período de amostragem, a alta densidade de indivíduos regenerantes possivelmente provocou uma grande competição entre eles por nutrientes, luz e espaço, causando um processo seletivo natural dos indivíduos ali instalados. A suscetibilidade das plântulas em relação aos fatores climáticos, também deve ter influenciado a mortalidade dos indivíduos recém regenerados, uma vez que estavam mais susceptíveis ao estresse hídrico do solo no período seco, já que o experimento não foi submetido a nenhum processo de irrigação. Vale ressaltar que não ocorreu geada no local do experimento durante o período de acompanhamento, mas houve frio intenso entre a primeira e segunda amostragem e segunda e terceira amostragem.

Outro aspecto que deve ser considerado foi a predação das plântulas e indivíduos jovens por herbivoria, constatada pela presença da lebre européia (espécie exótica) na área, nos primeiros meses após a instalação do experimento. Entretanto, vale ressaltar que a mortalidade apresentada não afetou o sucesso da ocupação da área por indivíduos de espécies arbustivo-arbóreas, mas pode ter interferido na diversidade das espécies desse processo. Por outro lado, a mortalidade torna-se interessante, uma vez que, a densidade de indivíduos encontra-se extremamente elevada, causando grande competição entre plantas, conseqüentemente retardando o crescimento das mesmas.

Também é importante ressaltar que os indivíduos regenerados no banco de sementes alóctone não apresentaram apenas a forma de vida arbustivo-arbórea, mas sim, várias outras formas de vida, que apesar de não terem sido quantificadas nesse trabalho, 
certamente representam grande contribuição para o resgate da diversidade vegetal e o restabelecimento dos processos e funções de uma área restaurada (Rodrigues \& Gandolfi, 2004). Entre os grupos de espécies não contabilizados estão os arbustos, que contribuiram de forma expressiva na densidade de indivíduos regenerados, entre eles se destacou o Baccharis dracunculifolia DC (vassoura).

$\mathrm{Na}$ testemunha não foi amostrado nenhum indivíduo germinado de espécie arbórea, o que demonstrou que provavelmente não houve chuva de sementes oriundas de fragmentos do entorno da área experimental. Outra possibilidade seria que as sementes oriundas do entorno estão chegando, mas não conseguiram se estabelecer no local. No entanto, a testemunha teve sua área quase totalmente colonizada por Braquiária (Brachiaria decumbens Stapf), no período entre a segunda e a terceira amostragem.

Esse fato chama a atenção para a necessidade de criação de técnicas de controle de espécies invasoras até que o banco possa se estabelecer, principalmente a braquiária que apresenta processos alelopáticos (Toledo et al., 2001). O controle da braquiária é hoje um dos maiores desafios para a restauração de áreas degradadas principalmente por meio de semeadura direta. Atualmente, a técnica de semeadura direta ou de uso do banco de sementes, pode ser eficiente apenas em ambientes onde as gramíneas agressivas, como braquiária, capim gordura, entre outros, já foram eliminados ou então não estão presentes na área, como taludes, bermas, áreas agrícolas de alta tecnologia, etc.

$\mathrm{Na}$ primeira amostragem dos indivíduos regenerados do banco de sementes alóctone, todas as 5 espécies identificadas pertenciam ao grupo sucessional das pioneiras, sendo que as não-pioneiras começaram a ser amostradas com duas espécies na segunda amostragem e outras duas espécies na terceira amostragem, totalizando depois de 19 meses, 4 espécies não-pioneiras $(22,2 \%)$ e 14 pioneiras (77,8\%). Esses valores refletiram as características das espécies iniciais de sucessão que predominaram no banco de sementes persistentes do solo (Denslow \& Gómez Dias, 1990; Martinez Ramoz \& Soto-Castro, 1993; Mantovani, 1994), aguardando um estímulo, como a presença de luz na abertura de clareiras, para sua germinação e desenvolvimento (Tabela 2). 
Tabela 2. Espécies amostradas, autores, famílias botânicas, nome popular, classes sucessionais e amostragem do banco de sementes da Fazenda Intermontes, CCRG, Ribeirão Grande, SP. C.S. - Classificação sucessional $\mathrm{P}=$ Pioneira; $\mathrm{NP}=$ Não-Pioneira. S.D. - Síndrome de dispersão: $\mathrm{AN}=$ anemocóricas; $\mathrm{AU}=$ autocóricas; $\mathrm{ZO}=$ zoocóricas. $\mathrm{T}$. = tamanho da semente. $\mathrm{p}=$ pequena; $\mathrm{m}=$ média; $\mathrm{g}$ : grande. $1^{\mathrm{o}}$ - primeira amostragem $(1 \mathrm{mês}) .2^{\mathrm{o}}$ - segunda amostragem (13 meses). $3^{\circ}$ - terceira amostragem (19 meses). Tamanho da semente: $\mathrm{p}=$ pequena; $\mathrm{m}=$ média; $\mathrm{g}=$ grande

\begin{tabular}{|c|c|c|c|c|c|c|c|c|c|}
\hline \multirow[b]{2}{*}{ Família } & \multirow[b]{2}{*}{ Nome Científico } & \multirow[b]{2}{*}{ Autor } & \multirow[b]{2}{*}{ Nome Popular } & \multirow[b]{2}{*}{ C.S. } & \multirow[b]{2}{*}{ S.D. } & \multicolumn{4}{|c|}{ Amostragem } \\
\hline & & & & & & T. & $\mathbf{1}^{\mathrm{o}}$ & $2^{o}$ & $3^{0}$ \\
\hline Boraginaceae & Cordia trichotoma & $\begin{array}{l}\text { (Vell.) Arráb. ex } \\
\text { Steud. }\end{array}$ & Louro pardo & NP & AN & $\mathrm{p}$ & & $X$ & \\
\hline $\begin{array}{l}\text { Fabaceae } \\
\text { Caesalpinioideae }\end{array}$ & Schizolobium parahyba & (Vell.) S.F. Blake & Guapuruvu & $\mathrm{P}$ & $\mathrm{AN}$ & $\mathrm{g}$ & $X$ & $\mathrm{X}$ & $\mathrm{X}$ \\
\hline $\begin{array}{l}\text { Fabaceae } \\
\text { Caesalpinioideae }\end{array}$ & Senna multijuga & $\begin{array}{l}\text { (Rich.) H.S. Irwin\& } \\
\text { Barneby }\end{array}$ & Pau cigarra & $\mathrm{P}$ & $\mathrm{AN}$ & $\mathrm{p}$ & $X$ & $\mathrm{X}$ & $\mathrm{X}$ \\
\hline $\begin{array}{l}\text { Fabaceae } \\
\text { Caesalpinioideae }\end{array}$ & Senna pendula & $\begin{array}{l}\text { (Humb. \& Bonpl. ex } \\
\text { Willd.) H.S. Irwin \& } \\
\text { Barneby }\end{array}$ & Canudo-de-pito & $\mathrm{P}$ & $\mathrm{ZO}$ & $\mathrm{p}$ & & & $\mathrm{X}$ \\
\hline Cannabaceae & Trema micrantha & (L.) Blume & Crindiúva & $\mathrm{P}$ & $\mathrm{ZO}$ & $\mathrm{p}$ & $X$ & $\mathrm{X}$ & $\mathrm{X}$ \\
\hline Euphobiaceae & Alchornea glandulosa & Poepp. & Tapiá & $\mathrm{P}$ & $\mathrm{ZO}$ & $\mathrm{p}$ & & & $X$ \\
\hline Euphobiaceae & Sapium glandulatum & (Vell.) Pax & Pau-de-leite & $\mathrm{P}$ & $\mathrm{ZO}$ & $\mathrm{p}$ & & $\mathrm{X}$ & \\
\hline Euphorbiaceae & Croton floribundus & Spreng. & Capixingui & $\mathrm{P}$ & $\mathrm{AU}$ & $\mathrm{p}$ & $X$ & $\mathrm{X}$ & $\mathrm{X}$ \\
\hline $\begin{array}{l}\text { Fabaceae } \\
\text { Faboideae }\end{array}$ & Machaerium stipitatum & (DC.) Vogel & Sapuvinha & $\mathrm{P}$ & AN & $\mathrm{m}$ & & $\mathrm{X}$ & $\mathrm{X}$ \\
\hline Lauraceae & Ocotea dispersa & (Nees) Mez & Canela & NP & $\mathrm{ZO}$ & $\mathrm{m}$ & & & $\mathrm{X}$ \\
\hline Malvaceae & Luehea divaricata & Mart. & Açoita-cavalo & $\mathrm{P}$ & $\mathrm{AN}$ & $\mathrm{p}$ & & $\mathrm{X}$ & \\
\hline $\begin{array}{l}\text { Fabaceae } \\
\text { Mimosoideae }\end{array}$ & Piptadenia paniculata & Benth. & Arranha-Gato & $\mathrm{P}$ & $\mathrm{AU}$ & $\mathrm{m}$ & & & $\mathrm{X}$ \\
\hline Myrsinaceae & Rapanea ferruginea & (Ruiz \& Pav.) Mez & Capororoca & $\mathrm{P}$ & $\mathrm{ZO}$ & $\mathrm{p}$ & & $\mathrm{X}$ & $\mathrm{X}$ \\
\hline Myrtaceae & Eugenia sp & --- & & $\mathrm{NP} *$ & ZO* & $\mathrm{m}$ & & $\mathrm{X}$ & \\
\hline Rosaceae & Prunus myrtifolia & (L.) Urb. & Pessegueiro-bravo & $\mathrm{P}$ & $\mathrm{ZO}$ & $\mathrm{m}$ & & $\mathrm{X}$ & \\
\hline Rutaceae & Zanthoxylum rhoifolium & Lam. & Mamica-de-porca & $P$ & $\mathrm{ZO}$ & $\mathrm{p}$ & $\mathrm{X}$ & $\mathrm{X}$ & $\mathrm{X}$ \\
\hline Sapindaceae & Cupania vernalis & Camb. & Camboatá & NP & $\mathrm{ZO}$ & $\mathrm{m}$ & & & $X$ \\
\hline Solanaceae & $\begin{array}{l}\text { Solanum granuloso- } \\
\text { leprosum }\end{array}$ & Dunal & Gravitinga & $\mathrm{P}$ & $\mathrm{ZO}$ & $\mathrm{p}$ & & & $\mathrm{X}$ \\
\hline
\end{tabular}

* Classificação baseada na característica predominante do gênero Eugênia na região (Lorenzi, 2002)

A Tabela 2 também chama a atenção para o fato do aparecimento de baixa riqueza de espécies que surgiu na ocupação da área experimental por indivíduos regenerados do banco de sementes alóctone. A contribuição do banco de sementes na regeneração dessas florestas geralmente é apenas de algumas espécies iniciais da sucessão (Baider et al., 2001), não apresentando riqueza de espécies arbóreas.

A composição do banco de sementes varia ao longo das estações do ano, sendo que, em função da longevidade dos diásporos, os bancos podem ser caracterizados como transitórios, ou seja, formados por sementes de curta viabilidade, ou persistentes, compostos por sementes de maior longevidade sob condições naturais (Grombone- 
Guaratini \& Rodrigues, 2002; Almeida-Cortez, 2004). Poucas espécies permanecem ativas no banco de sementes, sendo a maioria pertencente ao grupo de sementes persistentes e ocasionalmente algumas sementes transitórias (Holthuijen \& Boerboom, 1982; Garwood, 1989; Almeida-Cortez, 2004).

Aparentemente o aumento do número de espécies encontradas nas 3 amostragens, passando de 5 na primeira, 12 na segunda e 13 na terceira, totalizando 18 nos 3 levantamentos, juntamente com o aparecimento de espécies de estágios sucessionais mais avançados, sugerem um possível aumento do número de espécies no tempo. No terceiro levantamento de indivíduos regenerantes do banco de sementes alóctone, 4 espécies amostradas no segundo levantamento não foram encontradas. Esse fato pode estar ligado à metodologia amostral adotada ou ainda uma possível mortalidade dos indivíduos das espécies mais iniciais de sucessão no processo de seleção.

Vale ressaltar que existe a possibilidade das espécies dos estágios finais da sucessão que apareceram no segundo e terceiro levantamento serem oriundas de fragmentos da região (Figura 3), através da dispersão, uma vez que geralmente formam banco de sementes transitório ou temporário (Ferrettiet al., 1995).

Independente da baixa diversidade, a ocupação da área em recuperação com alta densidade de indivíduos de espécies arbustivo-arbóreos desencadeia uma série de processos, como a chegada de propágulos oriundos da fauna dispersora, que usam esses indivíduos regenerados como poleiros (Melo, 1997). Parrota et al. (1997) relataram que durante os primeiros anos das áreas reflorestadas, elas produzem um efeito catalítico, promovendo mudanças nas condições microclimáticas, aumentando a complexidade estrutural da vegetação e desenvolvendo camadas de serapilheira e humos. Isso faz com que aumente a chegada de sementes na área através da atratividade de agentes dispersores. Ao mesmo tempo essas mudanças geram condições propícias à germinação e desenvolvimento das espécies (Vieira, 2004).

Dessa forma, seria necessário um monitoramento por um período maior, avaliando o crescimento do número de espécies para a constatação da necessidade ou não de um enriquecimento, uma vez que no entorno da área experimental ainda existem 
vários fragmentos florestais com boa diversidade (Figura 3), possibilitando a chegada de propágulos de espécies ainda não instaladas no local através da chuva de sementes.

Quanto à síndrome de dispersão, 5 espécies (22,2\%) apresentam síndrome de dispersão pelo vento (anemocóricas), 11 espécies (66,7\%) são dispersas por animais (zoocóricas) e 2 espécies (11,1\%) possuem dispersão própria (autocóricas). Das quatro espécies encontradas nesse trabalho que apresentam as maiores densidades de indivíduos regenerantes (Tabelas 3 e 4), três são zoocóricas (Trema micrantha, Zanthoxylum rhoifolium, Rapanea ferruginea) e uma é autocórica (Croton floribundus), sendo todas elas pioneiras, com sementes pequenas (mais de 35.000 sementes/Kg) e apresentando dormência (Cardoso, 2004; Salomão et al., 2003; Yamazoe \& Vilas-Bôas, 2003).

Em uma das espécies amostradas, Machaerium stipitatum, constatou-se a regeneração dos seus indivíduos pela rebrota de raiz, que foi carregada junto com material (solo) extraído da mina Limeira, revelando que nem sempre os indivíduos regenerantes são originados pela germinação de sementes, mas também de partes vegetais diversas. Outras espécies como o guapuruvu e o pau-cigarra, pelas características de suas sementes que apresentam dormência física (Cardoso, 2004), provavelmente constituem o banco de sementes persistentes, mas com uma distribuição espacial limitada, pois apresentaram baixa freqüência na amostragem. Provavelmente isso deve ter ocorrido devido ao fato de sua dispersão ser realizada pelo vento, limitando o raio de dispersão para locais não muito distantes da planta mãe.

A Trema micrantha apresentou uma densidade bastante discrepante em relação as outras espécies, sendo na primeira amostragem 95,3 \% do total de indivíduos amostrados (Tabela 3). Na segunda e terceira amostragem, esses números, embora tenham apresentado uma pequena queda, ainda permanecem bastante elevados, sendo $84,8 \%$ e 76,3 \%, respectivamente. Essa diminuição das porcentagens de Trema micrantha em relação ao total de indivíduos revela, além da queda do número de indivíduos da sua população, uma substituição por outras espécies aparentemente mais adaptadas ao local como o Croton floribundus, por exemplo. (Rodrigues, 1999; Rozza, 2003; Farah, 2003). 
Trema micrantha é uma espécie bastante usada nos projetos de restauração florestal, principalmente pelas suas características de rápido crescimento e boa cobertura, sendo importante nos processos de "cicatrização" de clareiras ou de áreas perturbadas (Lorenzi, 2002; Rozza, 2003; Farah, 2003; Rodrigues et al., 2004a). Uma das características mais importantes de Trema micrantha para os reflorestamentos é a produção de pequenos frutos muito apreciados pela avifauna, o que certamente contribuirá com a implantação de fontes de alimento, atraindo animais dispersores de remanescentes florestais próximos para a própria área de recuperação (Lorenzi, 2002; Rozza, 2003; Farah, 2003; Rodrigues \& Gandofi, 2004). Essa é uma importante forma de acelerar o processo de recuperação, trazendo assim, propágulos de outras espécies, uma vez que estes animais defecam ou regurgitam sementes de outras espécies que trouxeram da floresta, aumentando a diversidade local.

Tabela 3. Número de indivíduos/espécies obtidos em março de 2003 nas áreas do banco de sementes da Fazenda Intermontes, CCRG, Ribeirão Grande, SP

\begin{tabular}{|c|c|c|c|c|c|c|c|c|}
\hline \multicolumn{3}{|c|}{$1^{\circ}$ amostragem (1 mês) } & \multicolumn{3}{|c|}{$2^{\circ}$ amostragem (13 meses) } & \multicolumn{3}{|c|}{$3^{\circ}$ amostragem (19 meses) } \\
\hline & & Ind/ ha & Nome Científico & NoInd. & Ind/ ha & Nome Científico & NoInd. & Ind/ ha \\
\hline Trema micrantha & 1.768 & 392.889 & 9 Trema micrantha & 543 & 120.667 & Trema micrantha & 348 & 77.333 \\
\hline Croton floribundus & 61 & 13.556 & Croton floribundus & 40 & 8.889 & Croton floribundus & 51 & 11.333 \\
\hline Zanthoxylum rhoifolium & 15 & 3.333 & Zanthoxylum rhoifolium & 17 & 3.778 & Zanthoxylum rhoifolium & 11 & 2.445 \\
\hline Schizolobium parahyba & 6 & 1.333 & Schizolobium parahyba & 1 & 222 & Schizolobium parahyba & 1 & 222 \\
\hline \multirow[t]{9}{*}{ Senna multijuga } & 5 & 1.111 & Senna multijuga & 9 & 2.000 & Senna multijuga & 3 & 667 \\
\hline & & & Rapanea ferruginea & 22 & 4.889 & $\begin{array}{l}\text { Rapanea ferruginea } \\
\text { Solanum granuloso- }\end{array}$ & 30 & 6.667 \\
\hline & & & Machaerium stiptatum & 2 & 444 & leprosum & 4 & 889 \\
\hline & & & Eugenia sp. & 2 & 444 & Machaerium stiptatum & 2 & 444 \\
\hline & & & Prunus myrtifolia & 1 & 222 & Ocotea dispersa & 2 & 444 \\
\hline & & & Luehea divaricata & 1 & 222 & Alchornea triplinervia & 1 & 222 \\
\hline & & & Cordia trichotoma & 1 & 222 & Senna pendula & 1 & 222 \\
\hline & & & Sapium glandulatum & 1 & 222 & Cupania vernalis & 1 & 222 \\
\hline & & & & & & Piptadenia paniculata & 1 & 222 \\
\hline
\end{tabular}

As características de tamanho, quantidade produzida e dormência das sementes de Trema micrantha, aliadas a um processo de dispersão bastante eficiente, resultaram na maior densidade dessa espécie no banco de sementes alóctone. Nesse contexto, é importante ressaltar que no local onde foi retirado o solo contendo o banco, não foi 
constatado nenhum indivíduo de Trema micrantha. Por outro lado, relatos de antigos moradores revelam que por volta de 1975, houve um grande incêndio florestal na área onde foi realizada a retirada do banco de sementes, que em parte era bastante explorada por pequenos agricultores. Esse fato pode ser confirmado através de fotografias aéreas do local de 1980, onde é constatado o alto grau de degradação da área. Dessa forma, podemos formular duas hipóteses para a alta densidade da Trema micrantha nos locais de retirada de solo: a) o elevado grau de degradação das áreas no entorno da mina no final da década de 70, onde foi retirado o banco de sementes, favoreceu a regeneração de um grande número de indivíduos de Trema micrantha, produzindo uma enorme quantidade de sementes depositadas no banco persistente do solo até os dias de hoje, embora a Trema micrantha, por ser uma pioneira típica e possuir ciclo de vida curto (Budowski, 1965; Kageyama \& Gandara, 2004, Barbosa, 2004), tenha sido substituída por espécies de estágio mais avançado da sucessão nos dias atuais; b) o sistema de dispersão da Trema micrantha através da avifauna é extremamente eficiente e, embora não tenha sido observado grande número de indivíduos desta espécie no fragmento florestal de onde foi retirado o banco, suas sementes encontram-se em grandes densidades no banco de sementes do solo.

No entanto, apesar das boas características da Trema micrantha para projetos de restauração florestal, já é conhecido que seu uso indiscriminado pode acarretar em sérios problemas, principalmente pelo fato de se tratar de uma espécie de ciclo de vida muito curto, geralmente de 10 a 15 anos, e as vezes até menor, quando sujeita a algum tipo de estresse (Budowski, 1965; Kageyama \& Gandara, 2004, Barbosa, 2004). Dessa forma, torna-se necessário que antes do término do ciclo de vida desta espécie, tenha sido garantida a presença de indivíduos regenerantes sob suas copas para que possam substituí-las após seu processo de senescência.

A Tabela 4 apresenta a altura média das espécies na segunda e terceira amostragens. O Croton floribundus teve um incremento em altura de 161,3\% da segunda para a terceira amostragem e a Trema micrantha um incremento de apenas 51,9 $\%$ nestas amostragens. 
Tabela 4. Altura média das espécies na segunda e terceira amostragem do banco de sementes da Fazenda Intermontes, CCRG, Ribeirão Grande SP

\begin{tabular}{|c|c|c|c|c|c|}
\hline \multirow[b]{2}{*}{ Nome Científico } & \multicolumn{2}{|c|}{ - (13 meses) } & \multirow[t]{2}{*}{$3^{\circ}$ amostragem } & \multicolumn{2}{|c|}{ - $\quad$ (19 meses) } \\
\hline & $\begin{array}{l}\mathrm{N}^{\mathrm{o}} \text { de } \\
\text { ind. } \\
\text { amostr. }\end{array}$ & $\begin{array}{l}\text { Alt. } \\
\text { média } \\
(\mathrm{cm})\end{array}$ & & $\begin{array}{l}\mathrm{N}^{\mathrm{o}} \text { de ind. } \\
\text { amostr. }\end{array}$ & $\begin{array}{l}\text { Alt. } \\
\text { média } \\
(\mathrm{cm})\end{array}$ \\
\hline Trema micrantha & 544 & 18,9 & Trema micrantha & 348 & 28,7 \\
\hline Croton floribundus & 40 & 26,6 & Croton floribundus & 51 & 69,5 \\
\hline Zanthoxylum rhoifolium & 17 & 8,6 & Zanthoxylum rhoifolium & 11 & 18,4 \\
\hline Schizolobium parahyba & 1 & 24,0 & Schizolobium parahyba & 1 & 75,0 \\
\hline Senna multijuga & 6 & 76,7 & Senna multijuga & 3 & 99,3 \\
\hline Rapanea ferruginea & 23 & 6,7 & Rapanea ferruginea & 30 & 14,9 \\
\hline Sapium glandulatum & 1 & 23,0 & Alchornea triplinervia & 1 & 43,0 \\
\hline Machaerium. stiptatum & 2 & 9 & Senna pendula & 1 & 90,0 \\
\hline Prunus myrtifolia & 1 & 20 & Cupania vernalis & 1 & 6,0 \\
\hline Luehea divaricata & 1 & 10 & Solanum granuloso-leprosum & 4 & 20,5 \\
\hline Eugenia sp. & 2 & 7 & Piptadenia paniculata & 1 & 5,0 \\
\hline Cordia trichotoma & 1 & 22 & Macharium stiptatum & 2 & 64,5 \\
\hline---- & ---- & ---- & Ocotea dispersa & 2 & 13,5 \\
\hline Média & & 19,2 & Média & & 32,8 \\
\hline
\end{tabular}

Esses resultados da Tabela 4 também sugerem a formação de dois grupos de altura na terceira amostragem. Um primeiro grupo com porte mais baixo (até $30 \mathrm{~cm}$ ) é dominado pela Trema micrantha, que possui a maior densidade de todas as espécies. Outras espécies que se destacam nesse grupo são: Zanthoxylum rhoifolium, Rapanea ferrugine e Solanum granuloso-leprosum. O grupo com cerca de 60 a $100 \mathrm{~cm}$ é dominado principalmente pela espécie Croton floribundus, que embora apresente uma densidade bem abaixo da apresentada pela Trema micrantha, já se destaca bastante na fisionomia pelo seu porte (Figura 9). Neste grupo também se destacam outras espécies como Schizolobium parahyba, Senna multijuga e Senna pendula.

Contudo, a primeira impressão é que os valores médios de altura parecem ser muito baixos para um plantio avaliado com 13 e 19 meses, no entanto, é preciso relacionar esse fato com a instalação do experimento sob área de corte e aterro, onde em 
sua maior parte se encontram as camadas mais pobres em nutrientes do solo. A faixa contendo solo fértil (faixa limite do corte e aterro - Figura 5), excluída dos levantamentos, apresenta uma fisionomia bem mais exuberante. Nessa faixa são encontradas praticamente as mesmas espécies em densidade semelhante a do restante das parcelas, seu dossel se encontra fechado, com 6 a $7 \mathrm{~m}$ de altura.

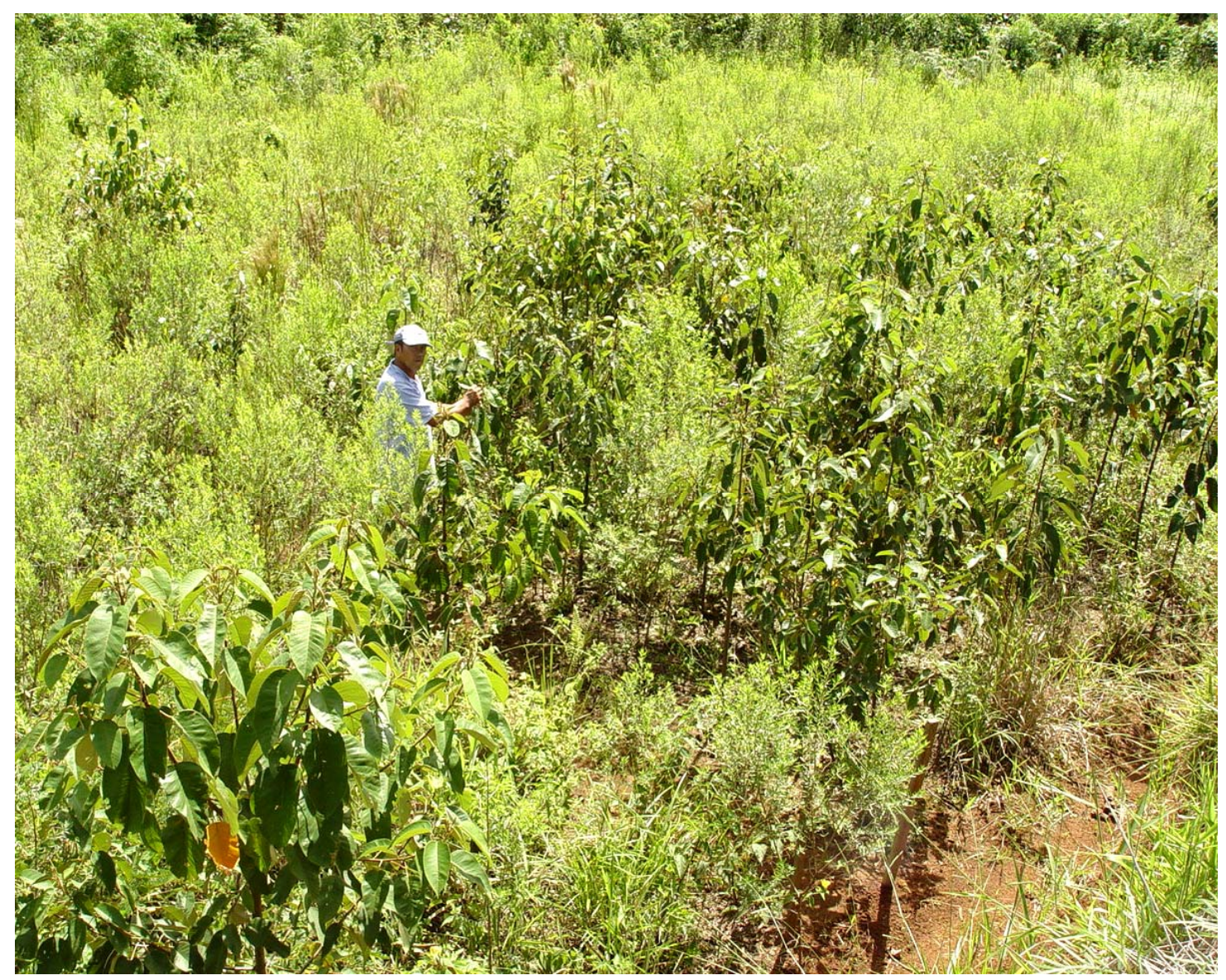

Figura 9 - Área experimental do banco de sementes alóctone na Fazenda Intermontes, dois anos após a implantação, CCRG, município de Ribeirão Grande, SP. Detalhe do desenvolvimento na área de corte do terreno. Destaque da população de Croton floribundus 
As Figuras 10, 11 e 12 mostram as situações nas parcelas com 24 meses após a instalação do experimento e as diferenças fisionômicas entre a faixa limite do corte e aterro e o restante das parcelas. A comparação, mesmo que visual dessas duas situações, deixa claro as diferenças de desenvolvimento dos indivíduos regenerantes em áreas com diferenças nutricionais nos solos, novamente ressaltando a importância de se considerar as condições do substrato na definição da metodologia de restauração e também na condução e monitoramento das áreas restauradas.

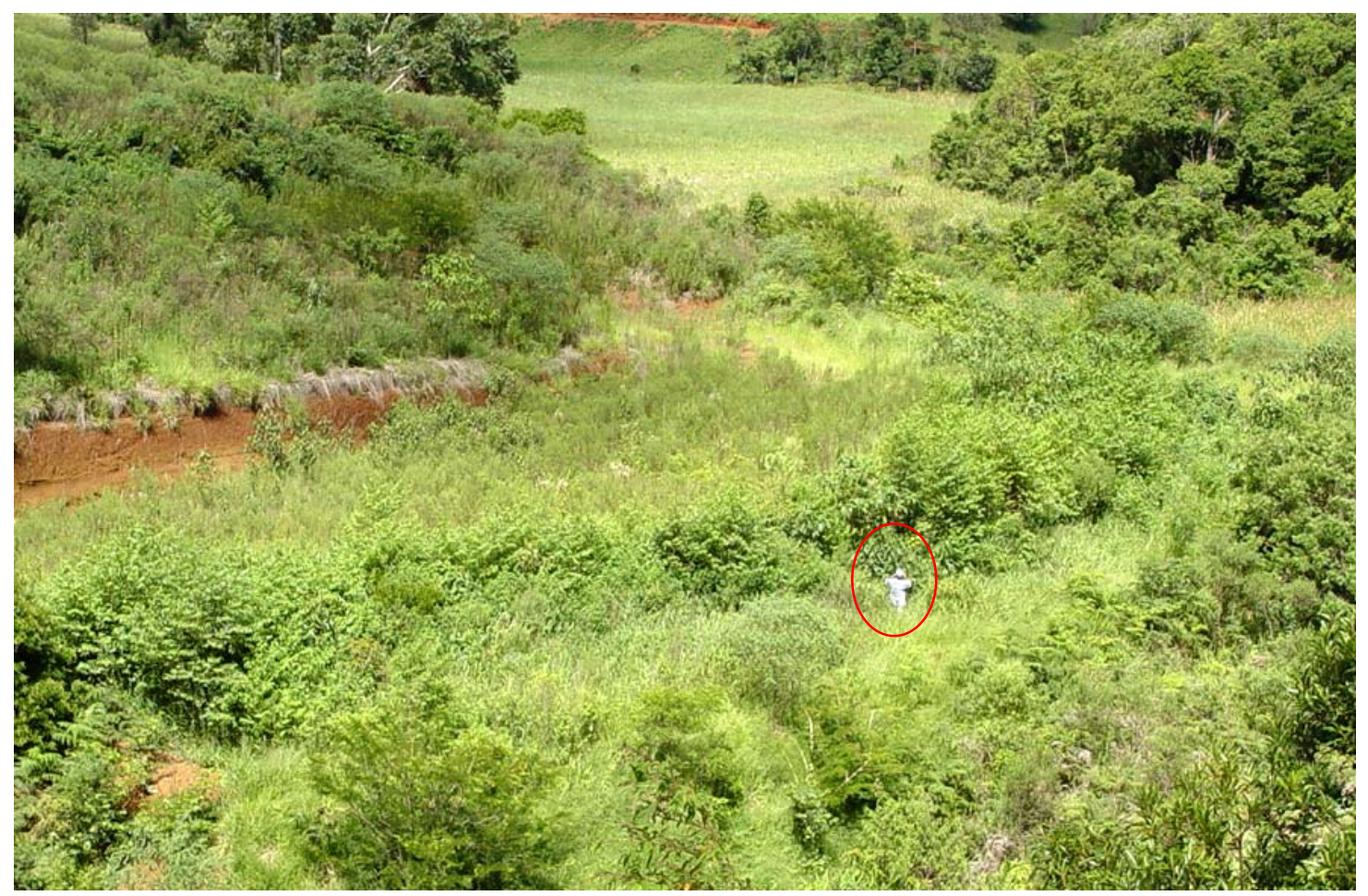

Figura 10 - Área experimental do banco de sementes alóctone na Fazenda Intermontes, dois anos após a implantação, CCRG, município de Ribeirão Grande, SP 


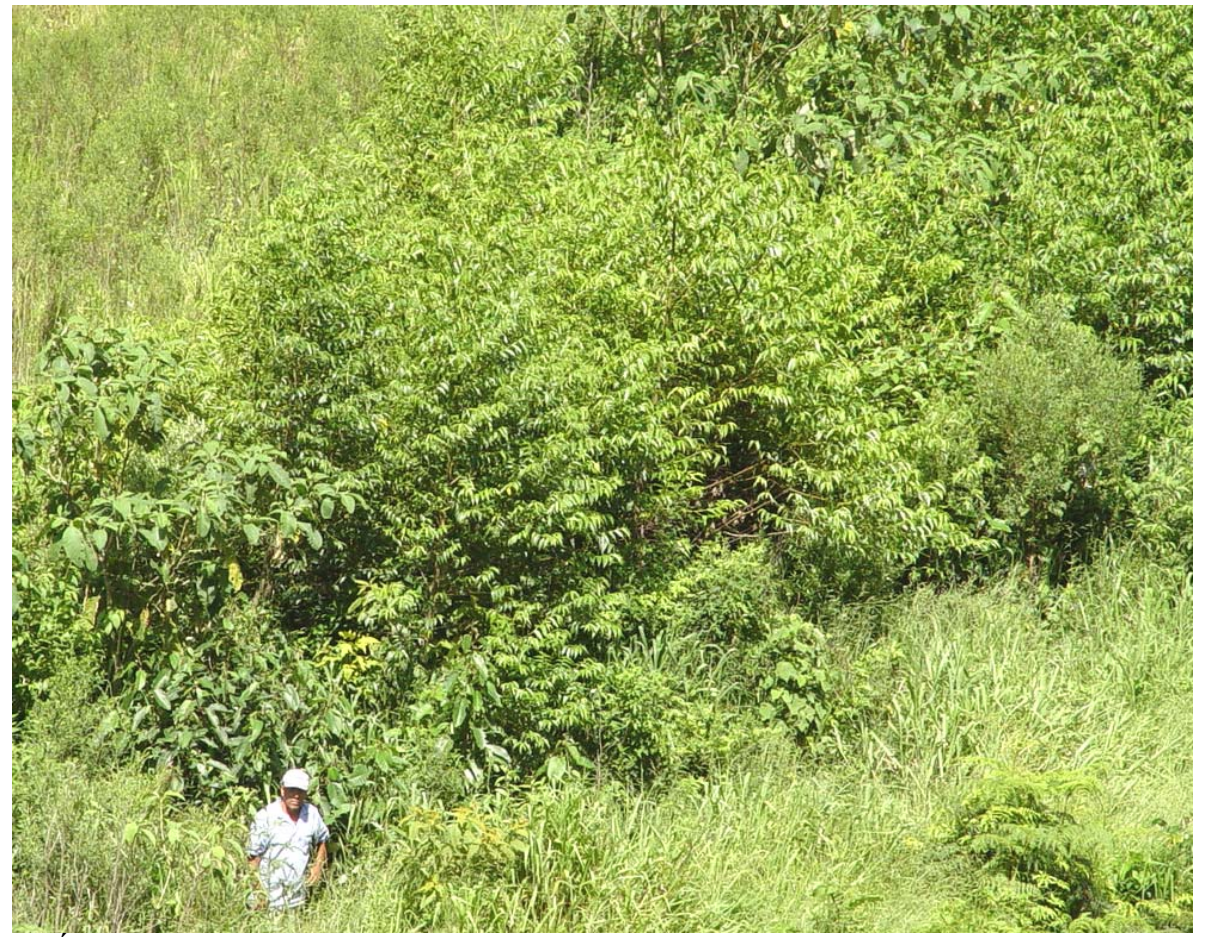

Figura 11 - Área experimental do banco de sementes alóctone na Fazenda Intermontes, dois anos após a implantação, CCRG, município de Ribeirão Grande, SP. Detalhe do maior desenvolvimento das plantas na linha de corte e aterro do terreno

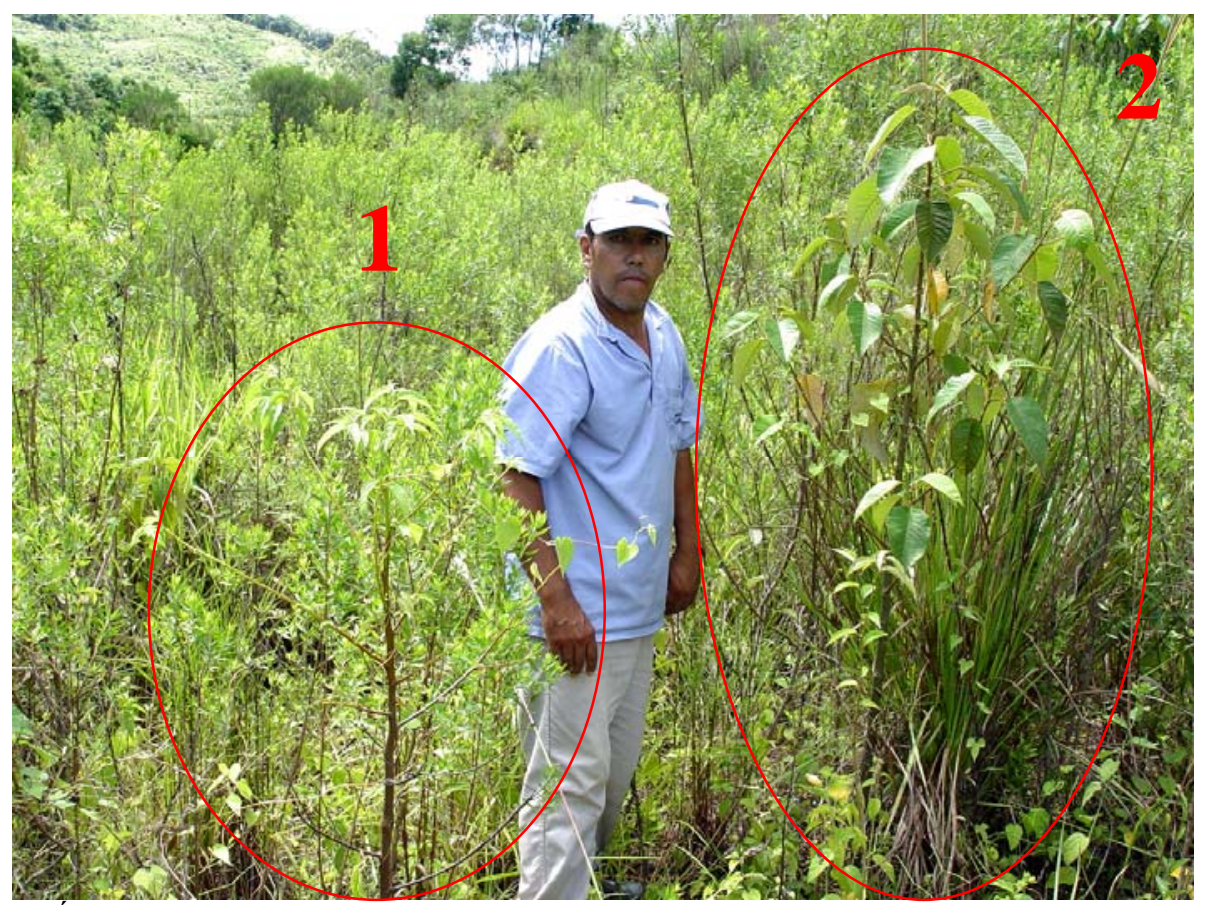

Figura 12 - Area experimental do banco de sementes alóctone na Fazenda Intermontes, dois anos após a implantação, CCRG, município de Ribeirão Grande, SP. Detalhe do desenvolvimento na área de corte do terreno. 1: Trema micrantha; 2: Croton floribundus 
Em função do baixo porte dos indivíduos regenerados, foi realizada uma adubação entre a segunda e terceira amostragem. Os resultados da adubação são apresentados na Figura 13.

Observa-se que a mediana de altura das parcelas sorteadas na área adubada é significativamente maior em relação à área não adubada.

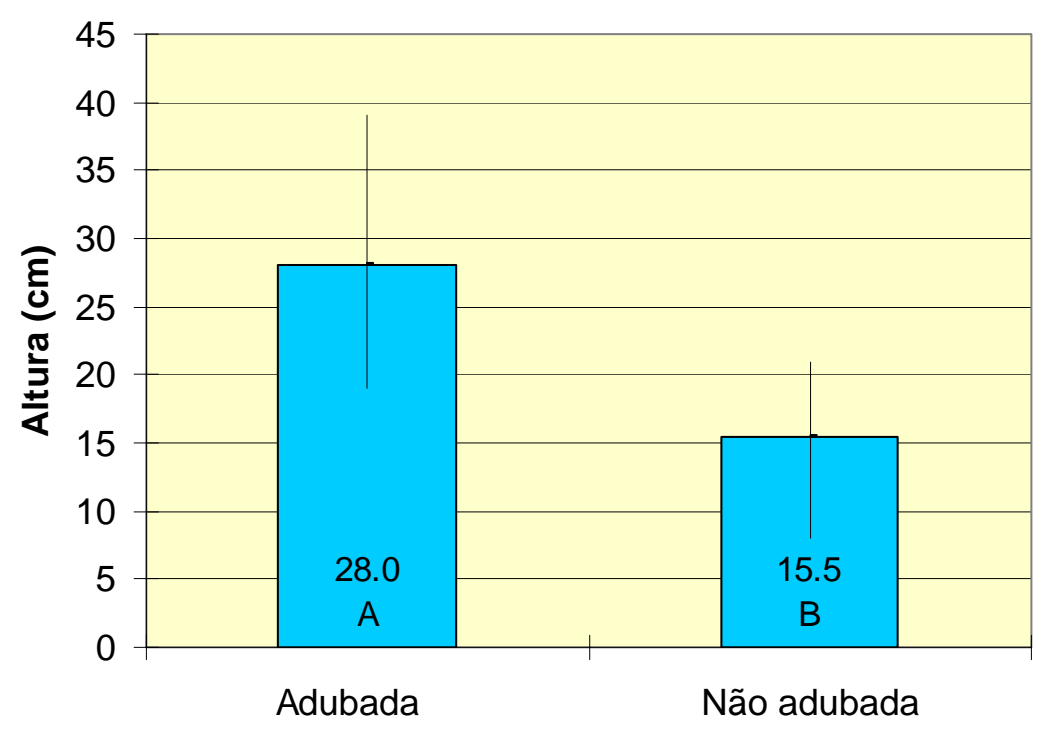

Figura 13 - Altura média entre as áreas adubadas e não adubadas (Medianas e limites do intervalo inter-quartis). Medianas com letras iguais não diferem entre si pelo teste de Wilcoxon com nível de significância de 5\%

De acordo com os resultados da terceira amostragem, na área onde houve adubação, as plantas apresentaram um acréscimo de 137,3\% em sua altura média em relação às não adubadas, passando de $15,2 \mathrm{~cm}$ para $36,1 \mathrm{~cm}$.

Em relação ao desenvolvimento de algumas espécies encontradas na área adubada e não adubada, foi interessante notar que as 3 espécies comuns nos dois tratamentos, que apresentavam pelo menos 10 indivíduos em cada um deles (Croton floribundus, Rapanea ferruginea e Trema micrantha), tiveram suas alturas médias incrementadas com a adubação nas proporções de 262,5\%, 77,0\%, e 26,9\%, 
respectivamente. Esse resultado mostrou a resposta de crescimento diferenciada entre as espécies em relação à adubação. Em função disso, pode-se se esperar uma influência da adubação na seleção e no estabelecimento de espécies na área adubada, uma vez que as espécies com maior porte deverão ter vantagens na competição por nutrientes, luz e espaço.

Contudo deve ser levado em consideração que a adubação foi realizada no final do período chuvoso e a última avaliação foi após o inverno, provavelmente interferindo no desenvolvimento das plantas. De qualquer forma, o incremento no desenvolvimento das plantas, mesmo considerando que foi feita adubação em um único período chuvoso, mostra que a atividade de adubação deve ser recomendada quando o banco de sementes for colocado em locais de baixa fertilidade do solo.

\subsection{Conclusões}

- A densidade dos indivíduos germinados se mostrou bastante elevada, com aproximadamente 409.334 indivíduos/ha, revelando a possibilidade de uso do banco de sementes alóctone como uma das metodologias de restauração de áreas degradadas.

- Foi constatada uma baixa riqueza de espécies arbustivo-arbóreas entre os indivíduos regenerantes do banco de sementes, sendo apresentadas 5 espécies na primeira amostragem, 12 na segunda e 13 na terceira. Vale ressaltar que o número de indivíduos de cada espécie não ocorre de maneira equilibrada no total amostrado. Nesse sentido, a Trema micrantha (L.) Blume se destaca pela discrepância da densidade de seus indivíduos, que correspondem na primeira amostragem a 95,3 \% do total de indivíduos amostrados $\mathrm{Na}$ segunda e terceira amostragens, esses números, embora tenham apresentado uma pequena queda, ainda permanecem bastante elevados, sendo $84,8 \%$ e $76,3 \%$, respectivamente. Entretanto, deve ser considerado que várias outras formas de vida não contabilizadas, como arbustos, herbáceas e lianas não agressivas, foram introduzidas com o solo contendo o banco de sementes alóctone, contribundo no aumento da diversidade. 
- O aumento acumulativo do número de espécies, passando de 5 na primeira amostragem para 18 na terceira, juntamente com o aparecimento de espécies de estágios sucessionais mais avançados, sugerem um possível aumento do número de espécies ao longo do tempo. Dessa forma, seria necessário um monitoramento por um período maior, avaliando o aumento do número de espécies e seus respectivos grupos ecológicos para a definição da necessidade ou não de um enriquecimento futuro da área, uma vez que no entorno da área experimental ainda existem vários fragmentos florestais com boa diversidade, possibilitando a chegada de propágulos de espécies ainda não estabelecidas na área através da chuva de sementes.

- No total das 18 espécies identificadas, 14 (77,8\%) foram classificadas como pioneiras e $4(22,2 \%)$ classificadas como não-pioneiras. Entretanto, na primeira amostragem, todas as 5 espécies identificadas pertenciam ao grupo sucessional das pioneiras.

- Quanto a síndrome de dispersão das espécies regeneradas do banco de sementes alóctone, 4 (22,2 \%) das espécies amostradas são anemocóricas, 12 (66,7\%) são dispersas zoocóricas e $2(11,1 \%)$ são autocóricas.

- Após a adubação realizada entre a segunda e terceira medição, os indivíduos arbóreos apresentaram, na área adubada, um acréscimo de 137,3 \% em sua altura média em relação aos indivíduos da área não adubada, passando de 15,23 cm para 36,14 cm. Esse acréscimo na altura média também foi notado de forma diferenciada para as 3 espécies mais abundantes, chegando a ser 262,5\% maior para Croton floribundus, $77,0 \%$ para Rapanea ferruginea e $26,9 \%$ para Trema micrantha. Portanto, a atividade de adubação deve ser recomendada principalmente quando o banco de sementes alóctone for depositado em locais de baixa fertilidade. 


\section{RESGATE DE INDIVÍDUOS ARBÓREOS REGENERANTES EM}

ÁREAS DE DESMATAMENTO, COMO ESTRATÉGIA COMPLEMENTAR DE PRODUÇÃO DE MUDAS DE ESPÉCIES NATIVAS COM DIVERSIDADE

\section{Resumo}

A produção de mudas por transplante de bancos naturais de plantas, apresenta a vantagem da adaptação climática do local onde foram resgatadas e podem ainda diminuir o custo de produção, uma vez que elimina ou reduz as atividades de coleta, processamento, plantio de sementes e tempo de permanência no viveiro. Esse trabalho busca fornecer informações técnicas sobre resgate de plântulas de indivíduos de espécies arbustivo-arbóreas regenerantes em remanescentes florestais, para obtenção de mudas nativas em viveiro. O trabalho de resgate de plântulas e de indivíduos jovens regenerantes da flora arbustivo-arbórea foi desenvolvido nos meses de julho (inverno) e dezembro (verão) de 2002. Em cada um dos dois resgates foram amostradas 50 parcelas de 2 X 2 metros $\left(4 \mathrm{~m}^{2}\right)$, dispostas aleatoriamente no entorno da Mina Limeira, em áreas ainda florestadas. A altura máxima e mínima das plantas foram $60 \mathrm{~cm}$ e $04 \mathrm{~cm}$. Após a retirada do local de origem, as plantas tiveram suas das folhas cortadas em 50\%. Foram levadas para o viveiro e transplantadas para os recipientes individuais. Após o transplante, as mudas foram mantidas sob sombrite $40 \%$. A sobrevivência e o desenvolvimento da muda foram observados pelo crescimento em altura e emissão de folhagem nova. Os resultados mostraram que a densidade dos indivíduos resgatados foi muito próxima para as duas épocas do ano, sendo 38.700 ind./ha e 37.900 ind./ha, mas com uma diferença significante para os indivíduos sobreviventes que apresentaram 
$16.500 \mathrm{ind} . /$ ha e 26.600 ind./ha para os meses de julho (inverno) e dezembro (verão) de 2002, respectivamente. Foi possível alcançar até 70,9\% de sobrevivência para os indivíduos resgatados em dezembro (verão) de 2002, com altura entre 04 e $20 \mathrm{~cm}$. As plântulas ou indivíduos juvenis contendo pelo menos duas folhas bem desenvolvidas e medindo entre $04 \mathrm{~cm}$ até $40 \mathrm{~cm}$ de altura se mostraram com as maiores taxas de sobrevivência e de densidade.

\section{Summary}

Seedlings production using plants from natural sites presents advantages since they are suitable to the local climatic conditions and represent budget reduction, once it eliminates or reduces the collecting activities, processing, seeds sowing and nursery treatment. This study searched for technical information about seedlings and woody growing individuals rescue from remaining natural forests, enhancing the number of native species on nurseries. Seedlings and young individuals were rescued during June and December 2002. Fifty squared plots of $2 \mathrm{~m} \times 2 \mathrm{~m}\left(4 \mathrm{~m}^{2}\right)$ were sampled and took a randomized arrangement on the remaining forested areas in the boundaries of Limeira mine. Plants maximum and minimum height were of $60 \mathrm{~cm}$ and $04 \mathrm{~cm}$. After extraction from their natural site, $50 \%$ of the leaves were cut off and then the plants were taken to the nursery where they were transferred to individual recipients. Seedlings were kept under $40 \%$ sunshade mesh. Seedling survival and development were observed by height and emission of young leaves. Rescued plants density was similar for both periods of the year, with $38.700 \mathrm{ind} / \mathrm{ha}$ and $37.900 \mathrm{ind} / \mathrm{ha}$. However, significant difference was found regarding the number of survivors for June (16.500 ind/ha) and December $(26.600$ ind./ha). Rescue technique achieved 70,9\% survival on December rescued individuals, with heights varying from 04 to $20 \mathrm{~cm}$. Seedlings and young individuals with at least two well developed leaves and 04 to $40 \mathrm{~cm}$ high presented the best chances of survival and density rate. 


\subsection{Introdução}

Com avanços do conhecimento e da legislação ambiental das últimas décadas, todo e qualquer tipo de empreendimento que cause danos ambientais deve ser elaborado de forma a promover o menor impacto possível durante sua implantação e operação. Uma das formas de diminuição dos impactos gerados pelas empresas pode ser obtida pelas "Medidas Mitigadoras", na qual se estabelece estratégias ou ações que visam minimizar os impactos gerados em suas atividades (Companhia de Cimento Ribeirão Grande - CCRG, 2003).

Nos casos em que a implantação de empreendimentos envolve a retirada de cobertura vegetal remanescente, uma das possíveis medidas mitigadoras a ser usada, é o resgate de indivíduos da flora (plântulas, jovens ou até mesmo adultos), existentes no local (CCRG, 2003; Rodrigues et al., 2004b).

A técnica de resgate de plantas oriundas da regeneração natural já é bastante conhecida entre os silvicultores europeus (Corvello, 1983). No Brasil, o primeiro relato do uso dessa técnica é do trabalho de restauração da Floresta Nacional da Tijuca iniciado em 1862, que usou no plantio de área degradada, indivíduos jovens retirados de florestas remanescentes do entorno (Cézar \& Oliveira, 1992). No entanto, existem bem poucos trabalhos na literatura científica que relatam esta técnica para o resgate de indivíduos regenerantes de espécies tropicais (Corvello, 1983; Thoma, 1998; Pareja, 1998; Viani, no prelo). Apesar disso, esse método é de grande importância não apenas para constituição da diversidade necessária em um programa de restauração, mas também, pela possibilidade de conservação do material genético que, de outra forma, seria suprimido. Por esses motivos, essa metodologia vem sendo estudada de forma mais intensiva nos últimos anos (Rodrigues \& Gandolfi, 1996).

Vale lembrar que na década de 1980, o avanço dos modelos de plantios de mudas usando a sucessão ecológica como fundamento básico (Kageyama \& Viana, 1989; Kageyama et al., 1990; Kageyama, 2003), deixaram a questão da diversidade em segundo plano (Souza \& Batista, 2004). Isso refletiu posteriormente com a senescência das espécies iniciais de sucessão, queda da diversidade e aumento de mato-competição 
(Barbosa, 2002; Souza \& Batista, 2004), revertendo algumas situações já reflorestadas, em áreas dominadas por gramíneas, principalmente como regenerantes nas clareiras (abundantes pela morte dos numerosos indivíduos de espécies pioneiras) e bordas do fragmento restaurado. Atualmente a importância da diversidade é indiscutível no restabelecimento dos processos ecológicos dos ecossistemas tropicais em restauração e fundamental na sua perpetuação (Rodrigues \& Gandolfi, 2004).

Dentro dos conceitos baseados no Paradigma Contemporâneo, Pickett et al., (1987) estabeleceu três condições para que ocorram os processos de sucessão em uma área a ser restaurada: a) Disponibilidade de local adequado; b) Disponibilidade de diferentes espécies; c) Disponibilidade de diferentes performances entre as espécies. O resgate de plântulas e indivíduos jovens regenerantes, como uma das estratégias de restauração, possibilita a disponibilidade de diferentes espécies das várias formas de vida, pois grande parte delas, principalmente dos estágios mais avançados da sucessão, se encontra no banco de plântulas da floresta ao longo do ano (Ferretti et al., 1995; Martins \& Rodrigues, 2002; Kageyama \& Gandara, 2004). As diferentes performances entre as espécies podem ser obtidas nessa metodologia de transferência de plântulas alóctone, tanto pela riqueza de espécies, quanto pela possibilidade de introdução de outras formas de vida como arbustos, herbáceas, lianas não agressivas, epífitas, as quais eram simplesmente ignoradas nas metodologias convencionais (Rodrigues et al., 2004b).

Assim, as novas concepções teóricas, baseadas no Paradigma do não equilíbrio, incorporam principalmente a idéia de restauração das funções do ambiente e dos processos ecológicos envolvidos, aumentando as chances de sustentabilidade do sistema, independente do clímax final alcançado (Fiedler et al., 1997; Pickettet al., 1992; Bazzaz, 1996).

Entretanto, existe ainda uma grande demanda de estudos para que a técnica de resgate de plantas se torne cada vez mais eficiente e de baixo custo. Alguns trabalhos já demonstraram que o transplante de plantas realizado diretamente para o local definitivo no campo, sem adaptação em viveiro, apresenta altas taxas de mortalidade devido à grande incidência de radiação solar. Esse fato pode ser contornado em viveiro através do uso de sombrite (Corvello, 1983; Thoma, 1998; Pareja, 1998). No entanto, Pareja (1998) 
mostra que os resultados das taxas de sobrevivência podem variar significativamente dependendo das características genéticas da matriz de uma determinada espécie, da qual se originaram as plantas resgatadas.

A grande vantagem dessa técnica é que pode ser usada também como forma complementar a coleta de sementes em viveiros florestais para aumentar a diversidade de espécies disponíveis. Além dessa demanda de diversidade de espécies, causada principalmente pela implantação da Resolução SMA 47, de 26 de novembro de 2003, na qual os viveiros são orientados a aumentar significativamente o número de espécies que vinham produzindo, existem problemas técnicos ainda não resolvidos para produção de mudas com diversidade de espécies (Fundação Florestal, 2004). Como exemplos podemos citar: o desconhecimento da quebra de dormência de algumas espécies; as dificuldades de coletas de sementes e; a sazonalidade na produção de sementes nas matrizes comumente visitadas, já que muitas espécies florestais são plurianuais, ou seja, florescem e frutificam a cada 2 ou até 4 anos (Thoma, 1998; Pareja, 1998; Kageyama \& Gandara, 2004).

A produção de mudas por transplante de bancos naturais de plantas, apresenta a vantagem da adaptação climática do local onde foram resgatadas e podem ainda diminuir o custo de produção, uma vez que elimina ou reduz as atividades de coleta, processamento, plantio de sementes e tempo de permanência no viveiro (Corvello, 1983).

No caso de viveiros comerciais, a fonte de plântulas ou indivíduos jovens de espécies arbustivo-arbóreas para o resgate, poderão ser ambientes não protegidos na legislação onde elas germinam naturalmente, como no interior de florestas exóticas (pinus e eucaliptos), nos aceiros em bordas de fragmentos, sob linhas de transmissão de energia elétrica, que são situações periodicamente sujeitas à eliminação de indivíduos jovens de espécies nativas, por determinação legal ou de proteção. Até mesmo remanescentes de florestas naturais poderiam ser alvo desse resgate, desde que seja desenvolvida metodologia consistente, resgatando plântulas e indivíduos jovens dentro de critérios técnicos devidamente desenvolvidos em trabalhos científicos, no que se refere a formação das plantas resgatadas, a diversidade resgatada, a densidade resgatada 
de cada espécie e a periodicidade desse resgate, que garantam o não comprometimento da dinâmica florestal nos trechos destinados para resgate (Viani, no prelo).

Cabe ressaltar que, segundo Moreira et al. (1986), do total de sementes germinadas compondo o banco de plântulas, cerca de 10\% conseguem ultrapassar a fase juvenil em razão dos processos inerentes da própria dinâmica florestal. Pareja (1998) ressalta, em seu trabalho realizado em áreas de cerrado, que a maior causa da mortalidade de plântulas em fragmentos naturais, pode ser causada pela dessecação, agravada pelo sistema radicular pouco profundo em período de estiagem. A utilização dessas plântulas que vão ser naturalmente eliminadas na dinâmica de regeneração ainda encontra-se em fase de estudos, mas poderá trazer grandes benefícios aos trabalhos de restauração.

Nesse contexto, esse trabalho busca fornecer informações técnicas sobre resgate de plântulas e de indivíduos jovens de espécies arbustivo-arbóreos regenerantes em remanescentes florestais, como possível estratégia complementar da produção de mudas de espécies nativas em viveiro, sendo mais uma ferramenta que visa o resgate da diversidade vegetal nessa atividade e conseqüentemente nos projetos de restauração ecológica. Nesse sentido, foram obtidos dados de densidade dos indivíduos resgatados, das taxas de sobrevivência das plantas em viveiro de acordo com classes de altura, de riqueza e diversidade de espécies e ainda da época do ano mais adequada para a realização do resgate, considerando os períodos de verão e de inverno.

\subsection{Material e métodos}

\subsection{1 Área de estudo}

Este trabalho foi desenvolvido na Companhia de Cimento Ribeirão Grande (CCRG), distante aproximadamente 12,5 km ao sul do município de Ribeirão Grande, SP e cerca de $250 \mathrm{~km}$ da cidade de São Paulo (Figura 1). A empresa tem como atividade mineraria a exploração de metacalcários e argila para produção de cimento. 


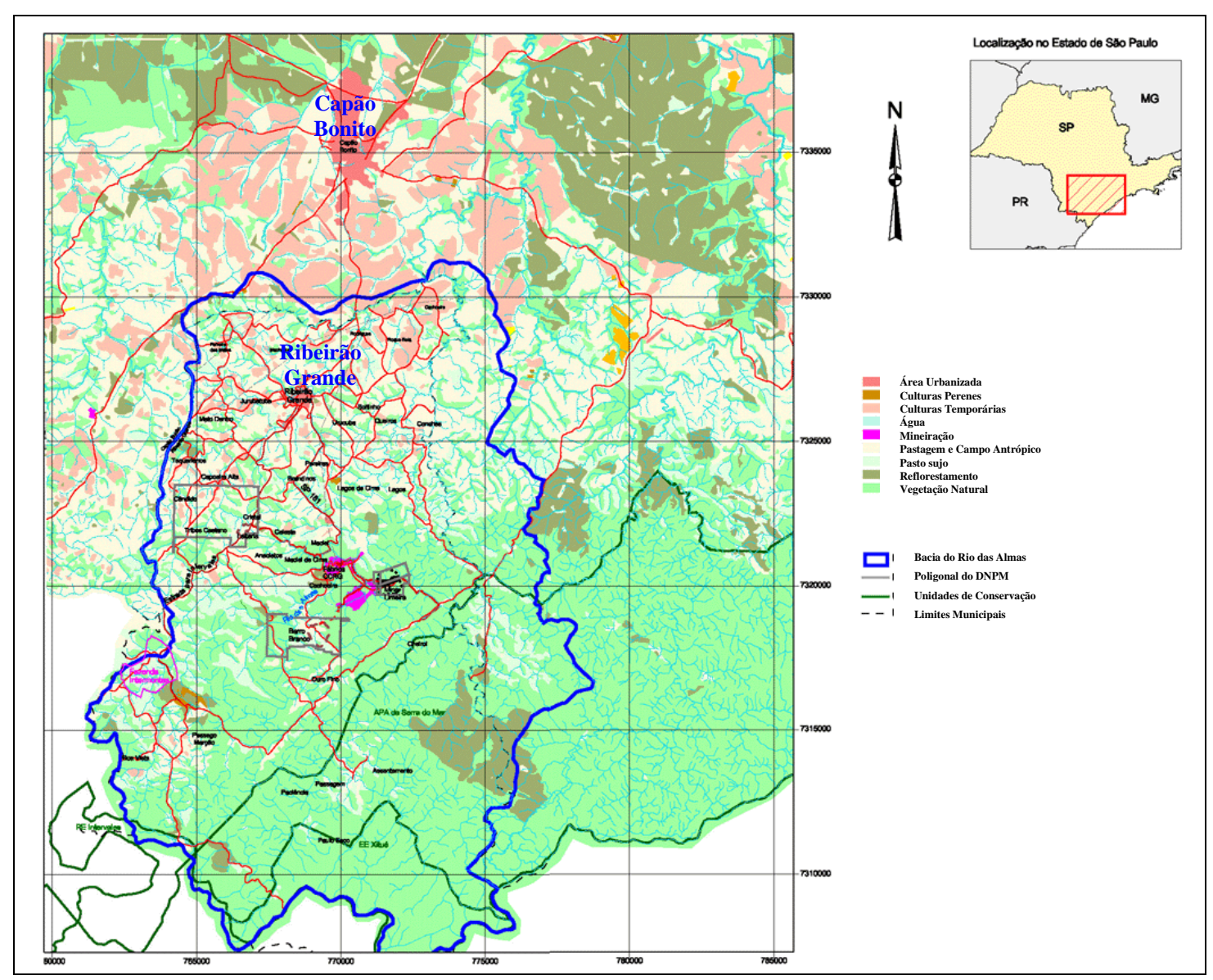

Figura 1 - Localização da região do município de Ribeirão Grande e da Cia. de Cimentos Ribeirão Grande no Estado de São Paulo

Diante da oportunidade de estudo sobre o aproveitamento de propágulos que seriam suprimidos com o corte da vegetação na Mina Limeira (autorizada pelo DEPRN em 08/02/2001), o Laboratório de Ecologia e Restauração Florestal (LERF) propôs para CCRG o resgate e uso do banco de plântulas e indivíduos jovens regenerantes como uma das medidas mitigadoras do impacto gerado pelo empreendimento. Essa atividade de restauração deu origem a esse trabalho, visando o desenvolvimento de novas metodologias para subsidiar as futuras atividades de restauração florestal.

A área onde foi realizado o resgate de plântulas e de indivíduos de espécies arbustivo-arbóreas regenerantes se encontra no entorno da Mina Limeira, pertencente à CCRG e localizada a cerca de $3 \mathrm{~km}$ da fábrica da empresa, na área rural denominada 
“Sumidouro" (Figura 2). Sua localização geográfica é dada pelas coordenadas 2409'20"

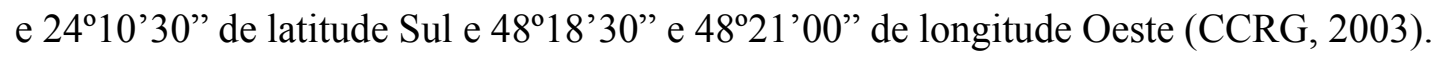

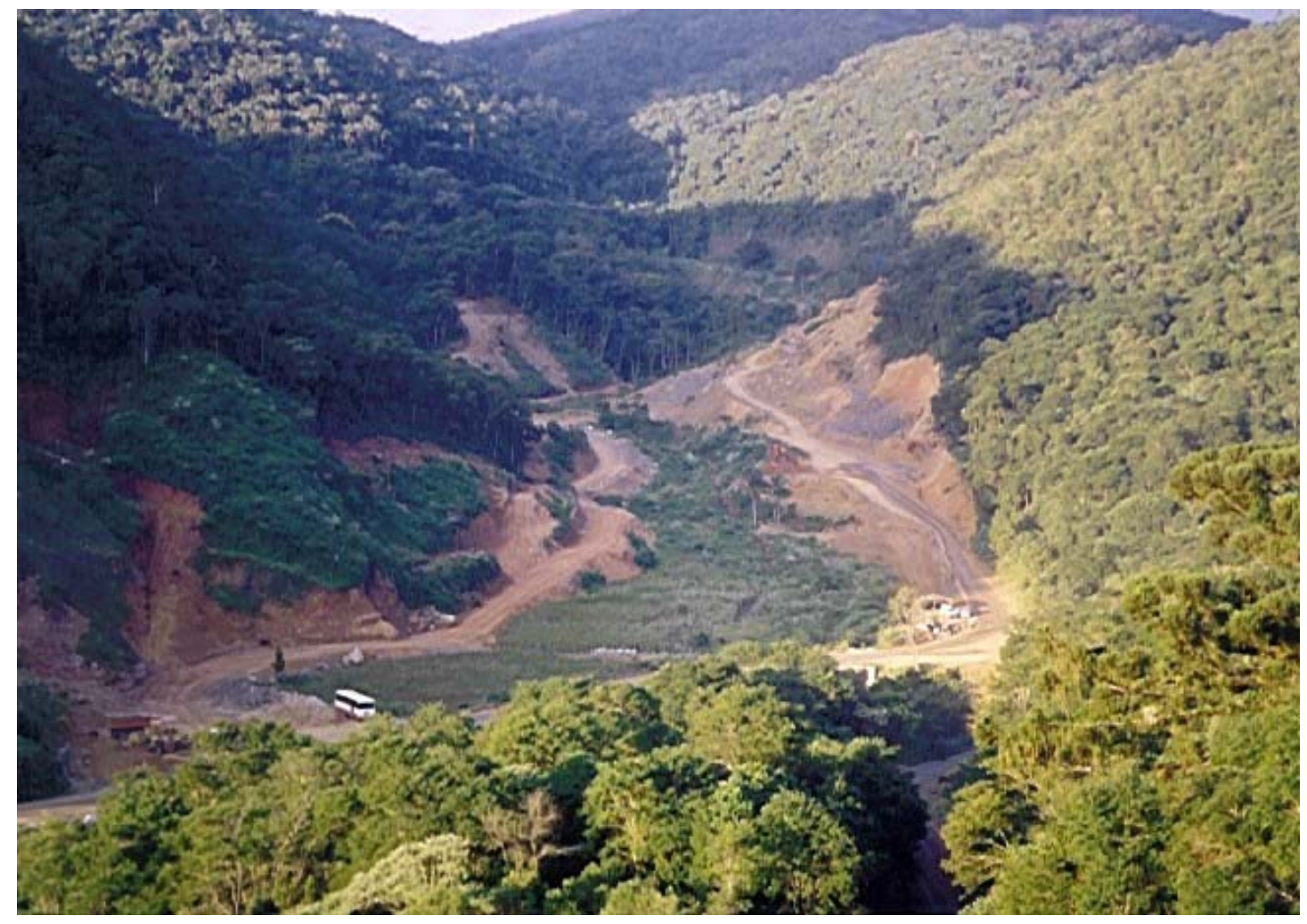

Figura 2 - Vista geral da Mina Limeira no início das atividades minerarias (2001) e vegetação do entorno onde foi resgatado o banco de plântulas e indivíduos jovens regenerantes, CCRG, município de Ribeirão Grande, SP

A área em estudo está inserida na Província Geomorfológica do Planalto Atlântico, Zona do Planalto de Guapiara, que compreende a região elevada do alto da Serra de Paranapiacaba e estende-se até a cobertura sedimentar da bacia do Paraná. É uma região que comporta os afluentes de alto curso da margem esquerda do Paranapanema, cuja borda sul marca o divisor de águas da drenagem continental (Vale do Paranapanema) e da litorânea (Vale do Ribeira). (CCRG, 2003) 
A declividade dominante está entre 20 a $30 \%$, onde os fundos dos vales estão acima de $800 \mathrm{~m}$ de altitude e os espigões muitas vezes ultrapassam $1.000 \mathrm{~m}$ de altitude (CCRG, 2003).

Essas características definem para região, segundo a classificação de Köeppen (1948), o clima temperado úmido sem estiagem (Cfb), que ocupa áreas do Planalto de Guapiara com altitudes superiores a $800 \mathrm{~m}$. Nessa parte mais alta da Serra de Paranapiacaba, as temperaturas médias são inferiores a $18^{\circ} \mathrm{C}$ no mês mais frio e inferiores a $22^{\circ} \mathrm{C}$ no mês mais quente (Nimer, 1989; Setzer, 1966).

A Mina Limeira está situada na bacia hidrográfica do Córrego do Chapéu, afluente da margem direita do Rio das Almas, que é um dos afluentes da margem direita do Rio Paranapanema. A precipitação média da bacia do Córrego do Chapéu é de 1300 $\mathrm{mm}$, variando de 1.100 e $1.500 \mathrm{~mm}$ por ano, com chuvas concentradas no verão, principalmente nos meses de dezembro, janeiro e fevereiro. Nessa região o período correspondente ao inverno é o que apresenta maior redução dos índices pluviométricos. O total pluviométrico do mês mais seco é superior a $30 \mathrm{~mm}$ (CCRG, 2003). As temperaturas mínimas absolutas anuais chegam a $-4{ }^{\circ} \mathrm{C}$, nas altitudes mais elevadas, ocorrendo em média um a cinco dias de geadas por ano (Nimer, 1989; Setzer, 1966).

\subsubsection{A vegetação regional}

A vegetação do município de Ribeirão Grande localiza-se no Planalto Atlântico do Estado de São Paulo, na divisa com a Província Costeira, próxima a escarpa do Planalto Atlântico, onde predomina a Floresta Estacional Semidecidual, mas devido à proximidade com a Serra de Paranapiacaba, apresenta muitas espécies típicas da Floresta Ombrófila Densa na composição florística local (CCRG, 2003).

A flora regional tem contribuições de várias formações, na região do Parque Estadual de Intervales ocorrem as chamadas Florestas Ombrófilas, por desenvolveremse em clima úmido sem período de estiagem (Mantovani, 1994). No reverso da Serra de Paranapiacaba, estende-se até Capão Bonito, o estremo norte do domínio da Floresta de Araucárias, formação dos climas temperados quentes e úmidos ou subtropicais úmidos 
do Sul do Brasil (Klein, 1984). Nas drenagens do Vale do Paranapanema, originam-se provavelmente as espécies típicas de Floresta Estacional Semidecidual do interior dos Estados de São Paulo, Paraná e Minas Gerais (Mantovani, 1994).

As florestas da região encontram-se em estádios diferenciados de sucessão, resultado de ocupação para prática de agricultura por períodos variáveis e pela extração seletiva de madeira e do palmiteiro (Mantovani, 1994). Geralmente os trechos florestais bem conservados encontram-se nas encostas mais íngremes ou em locais de difícil acesso.

\subsubsection{Histórico da área}

Por volta de 1975, segundo relato de moradores antigos, houve um incêndio florestal na região que acabou atingindo a vegetação do entorno da Mina Limeira, a qual já era bastante degradada pelas atividades de pequenos agricultores. Esse fato pode ser confirmado por meio de fotografias aéreas do local em 1980, em que é constatado alto grau de degradação da vegetação do entorno da Mina. Com a entrada do complexo minero-industrial em 1972, pelo Grupo empresarial João Santos, os moradores foram retirados do local e a vegetação natural entrou em processo de regeneração natural, formando atualmente uma floresta bastante exuberante, mas composta em sua maior parte por indivíduos de espécies iniciais da sucessão como Pau-jacarés, Guapuruvus, Tibouchina spp, Aroeira-pimenteiras, etc.

Deve ser considerado também que as florestas naturais remanescentes da região foram bastante exploradas historicamente com extração seletiva de madeiras nobres para construção civil, extração de palmito e produção de carvão (Guix, 1994; Reis et al., 1994). Entretanto, nessas florestas são encontrados muitos indivíduos de estágios finais de sucessão regenerantes no banco de plântulas, os quais foram resgatados e usados para este estudo. 


\subsubsection{Coleta de dados}

O resgate de indivíduos de espécies arbustivo-arbóreas regenerantes foi definido neste trabalho como: ato de resgatar as plântulas ou indivíduos jovens de espécies arbustivo-arbóreas nativas que regeneraram dentro ou no entorno de fragmentos florestais ou de reflorestamentos de espécies nativas ou exóticas, levando-os para adaptação e desenvolvimento em viveiro ou diretamente para o campo com o objetivo de sua utilização em áreas a serem restauradas.

Embora essa atividade possa ser realizada para as várias formas de vida (árvores, lianas não agressivas, epífitas, etc. e tamanhos de plantas), como feito parcialmente no trabalho de Viani (no prelo), neste trabalho foram estudados apenas os indivíduos jovens arbustivo-arbóreos, devido a sua importância inicial para estruturação inicial da florestal e a criação de ambientes favoráveis para o desenvolvimento das outras formas de vida (Parrota et al., 1997).

O trabalho de resgate de plântulas e de indivíduos jovens regenerantes da flora arbustivo-arbórea foi desenvolvido nos meses de julho (inverno) e dezembro (verão) de 2002, representando as estações de inverno e verão. Os resgates foram realizados num remanescente de floresta secundária localizada no entorno Mina Limeira, pertencente à empresa CCRG.

A metodologia utilizada no resgate dos indivíduos de espécies arbustivo-arbóreas em cada uma das parcelas, foi:

a) Retirada do local de origem: as mudas foram retiradas das parcelas com bastante cuidado, evitando a quebra de raízes. Isso foi feito com o auxílio de uma pá de jardinagem ou faca. Em seguida foi realizado o destorroamento até a planta ficar com a raiz nua. Em cada um dos dois resgates foram amostradas 50 parcelas de 2 X 2 metros (4 $\mathrm{m}^{2}$ ), dispostas aleatoriamente no entorno da Mina Limeira, em áreas ainda florestadas, totalizando $400 \mathrm{~m}^{2}$ de área submetida ao resgate de plântulas e indivíduos jovens nas duas campanhas. A aleatoriedade foi obtida por meio de sorteio de valores " $X$ " e "Y" medidas no campo a partir de estradas de acesso e trilhas perpendiculares que serviram como eixo para as coordenadas. 
b) Poda das folhas: devido ao desequilíbrio hídrico da planta causado pelo trauma na retirada da raiz do solo, foi realizado o corte de $50 \%$ de cada folha. Esse procedimento de cada folha também foi muito útil para acompanhar o desenvolvimento das mudas no viveiro, ficando fácil a visualização das novas folhas emitidas pela planta.

c) Transporte dos indivíduos resgatados para o viveiro: assim que retiradas do solo, as mudas referentes a cada parcela foram acondicionadas em recipientes individuais com água e alta umidade, em sacos plásticos fechados com água suficiente para cobrir as raízes. As mudas foram levadas para o viveiro e em seguida transferidas (repicadas) para recipientes definitivos em até 36 horas após sua coleta. As plantas resgatadas foram levadas para o viveiro do Parque Estadual de Intervales, localizado cerca de $20 \mathrm{~km}$ da Mina Limeira e a atividade de repicagem foi realizada dentro de 48 horas após o resgate. A Figura 3 mostra o fluxograma da atividade de resgate.

d) Repicagem dos indivíduos resgatados no viveiro: chama-se de repicagem a atividade de transferência das plântulas e indivíduos jovens da regeneração para o recipiente definitivo no viveiro. Cada parcela foi repicada de forma casualizada nos canteiros, ou seja, eram sorteadas para os locais onde seriam repicadas. Os recipientes utilizados foram saquinhos plásticos de polietileno preto com as seguintes dimensões: 20 de altura e 14 de largura. Essa atividade foi realizada sempre sob sombrite $40 \%$. A técnica de recobrimento com sombrite já é bastante conhecida na atividade de repicagem de plântulas em viveiros florestais e tem sido realizada com sucesso também no resgate de plantas (Macedo, 1993a; Pareja, 1998; Thoma, 1998; Guenji \& Villas Boas, 2003). A acomodação da raiz no saquinho foi cuidadosa para que a raiz não ficasse dobrada ou dentro de bolsas de ar formadas no substrato. Quando necessário, fez-se o corte da mesma. Nesta etapa, alguns cuidados devem ser tomados porque muitas raízes crescem tortas em ambiente natural e devem ser podadas para acomodação nos saquinhos. $\mathrm{O}$ mesmo é realizado para raízes muito compridas.

e) Substrato utilizado no viveiro: o substrato utilizado foi o normalmente usado em viveiros localizados em regiões canavieiras, contendo 2 partes de terra e 1 de torta de filtro (subproduto das Usinas), obtido em usinas da região. 
f) Tratos culturais no viveiro: os tratos realizados no viveiro para mudas resgatadas foram os mesmos utilizados para mudas comuns como regas freqüentes ( 2 vezes ao dia) por meio de sistema automatizado, controle de daninhas, etc. Não foram realizadas adubações de cobertura.

g) Sobrevivência e desenvolvimento: a sobrevivência e o desenvolvimento da muda foram observados pelo crescimento em altura e emissão de folhagem nova, registrada em planilha para determinação das taxas de sobrevivência e do ponto de expedição para campo. Esse trabalho foi realizado durante o terceiro e o sexto mês após a repicagem. A análise em um tempo menor poderia comprometer os resultados (Pareja; 1998, Thoma; 1998).

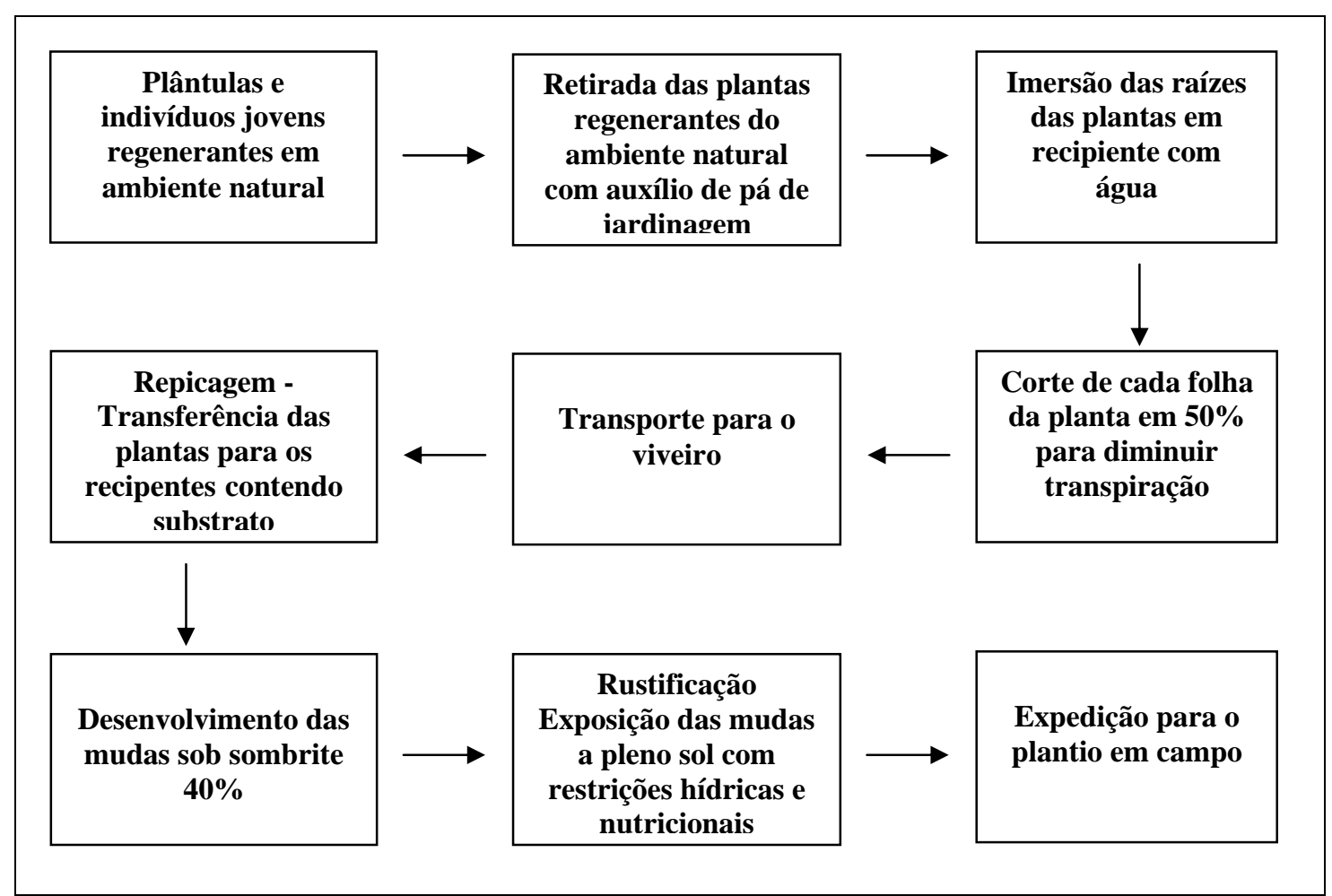

Figura 3 - Esquema de resgate de mudas arbustivo-arbóreas realizado na Mina Limeira, CCRG, município de Ribeirão Grande, SP

As Figuras 4, 5, 6 e 7 a seguir, mostram uma seqüência ilustrativa da atividade de resgate da flora arbórea até a etapa de repicagem no viveiro. 


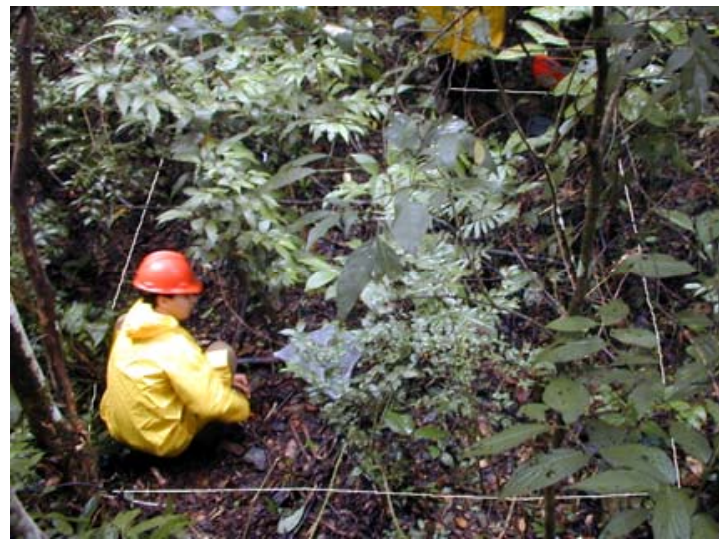

Figura 4 - Parcelas de 2 X $2 \mathrm{~m}$ instaladas no interior da floresta para o resgate de plantas, Mina Limeira, CCRG, município de Ribeirão Grande, SP

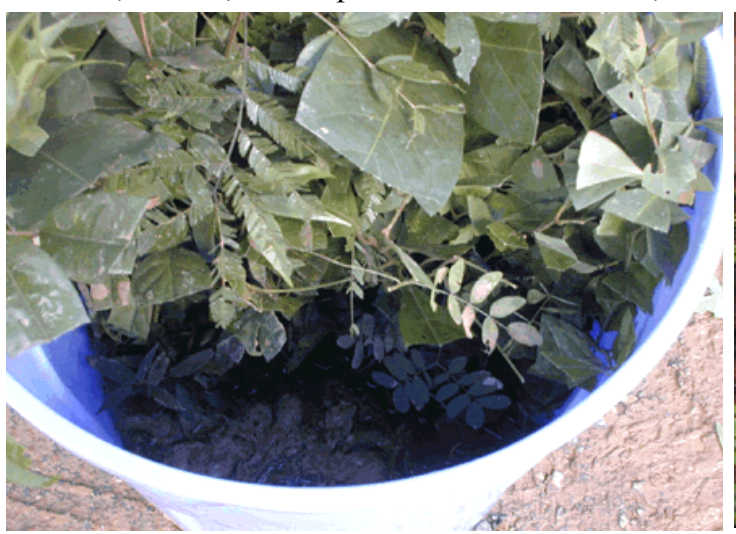

Figura 6 - Armazenamento em baldes com água na Mina Limeira, CCRG, município de Ribeirão Grande, SP

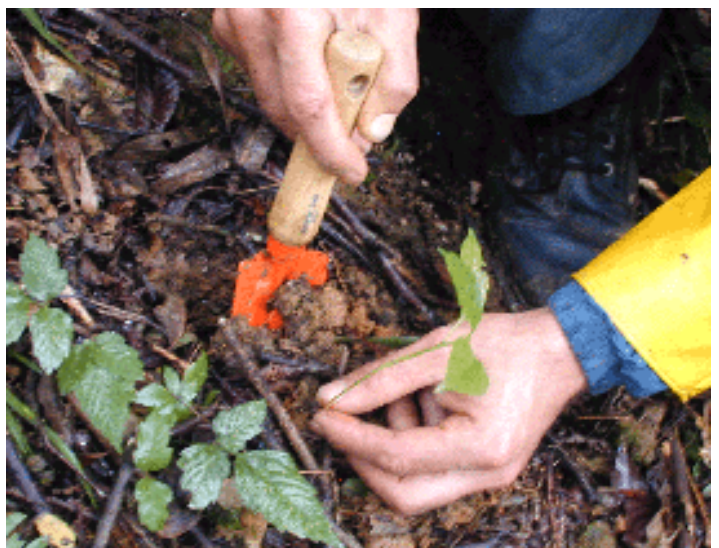

Figura 5 - Retirada da plântula com auxilio da pá na Mina Limeira, CCRG, município de Ribeirão Grande, SP

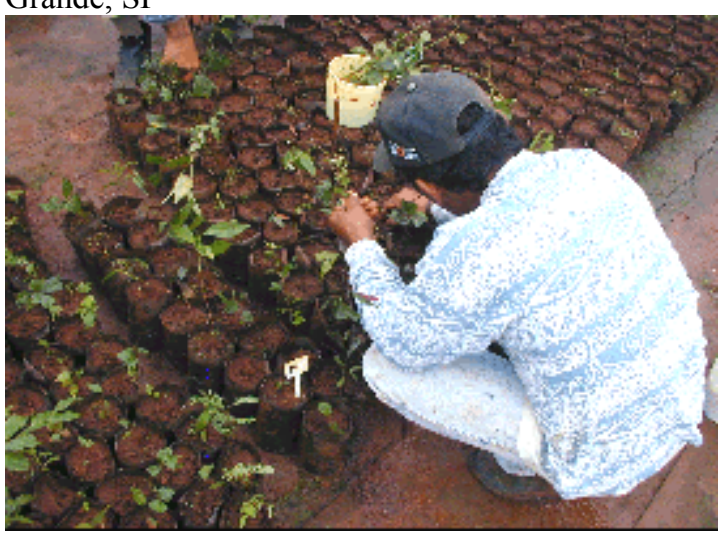

Figura 7 - Repicagem no viveiro do Parque Estadual de Intervales, município de Ribeirão Grande, SP

Uma das maiores dificuldades deste experimento foi a identificação de plântulas que apresentavam, na grande maioria, pouca estrutura foliar, o que não permitia a herborização da mesma no momento da coleta, uma vez que, a retirada de parte desta estrutura para identificação poderia comprometer a sobrevivência da muda. Outro problema era que, dentro da técnica adotada, na qual deveríamos cortar cada folha da planta pela metade, os indivíduos que apresentavam apenas cotilédones e/ou folhas ainda não totalmente desenvolvidas, ficariam prejudicados.

Nesse contexto, muitas das plântulas que não puderam ser herborizadas, principalmente as que apresentavam apenas cotilédones, acabavam por morrer sem identificação. Em função disso, foi adotado o número mínimo de 2 folhas bem 
desenvolvidas para inclusão do indivíduo resgatado. Com isso, o resultado do número de indivíduos amostrados no campo está subestimado, uma vez que, parte das plântulas encontradas não foi contabilizada em função de não apresentar o critério mínimo estabelecido.

Também foi definida a altura máxima de $60 \mathrm{~cm}$ para as plantas resgatadas. A altura mínima de $04 \mathrm{~cm}$ foi constatada em campo em função da presença de pelo menos duas folhas desenvolvidas. Cabe ressaltar que o critério de número mínimo de folhas também é usado nas técnicas de repicagem de plântulas e indivíduos jovens em viveiros, recomendando que as plântulas sejam repicadas com pelo menos 4 folhas (Macedo, 1993a). O número de folhas como critério de inclusão para o transplante de plântulas também foi usado por Thoma (1998).

\subsubsection{Análise dos dados}

Os parâmetros considerados foram: número de indivíduos, número de espécies, número de famílias, densidade relativa e frequência relativa (Whittaker, 1972; Mueller Dombois \& Ellemberg, 1974; Rodrigues, 1988). A densidade e a frequência são descritos a seguir:

- Densidade - A densidade de uma espécie em uma floresta é o número de indivíduos desta espécie por unidade de área. Se o número de indivíduos de tal espécie for dividido pelo número total de indivíduos de todas as espécies dentro da comunidade estudada, se obterá sua Densidade Relativa.

- Freqüência - A freqüência indica o número de parcelas em que uma espécie ocorre, em relação ao número total de parcelas. Esta variável é sensível aos padrões de distribuição dos indivíduos. O termo Freqüência Relativa designa a relação entre a freqüência de uma espécie dividida pela soma das freqüências de todas as espécies encontradas nas áreas amostradas.

Os dados foram analisados pelo FITOPAC (Shepherd, 1995) em duas etapas: a primeira refere-se à etapa de coleta das plantas no campo; a segunda refere-se à 
sobrevivência e desenvolvimento das plantas no viveiro após transplante. Nessa etapa usamos o parâmetro de presença de folhas novas para indicar sobrevivência. Os indivíduos que após o sexto mês não apresentaram nenhuma folha nova foram considerados mortos.

Com os resultados foi possível obter dados de riqueza, densidade relativa e freqüência relativa para a etapa de campo e viveiro. As espécies que mais se destacaram foram definidas pela soma da densidade relativa e freqüência relativa. Esses dados ainda foram analisados separadamente para as duas estações do ano em que foram coletados, no verão e inverno respectivamente (julho e dezembro de 2002).

Foi ainda realizada uma análise de sobrevivência e de número de indivíduos resgatados por classe de altura, considerando cada época amostral, em 3 grupos: a) indivíduos entre 4 a $20 \mathrm{~cm}$ de altura; b) indivíduos entre 21 a $40 \mathrm{~cm}$ de altura e; c) indivíduos entre 41 a $60 \mathrm{~cm}$ de altura. Dessa forma, foi possível analisar se existem classes de altura com porcentagens maiores de sobrevivência e a densidade de indivíduos resgatados em cada uma delas.

Para a colocação das espécies nas suas respectivas famílias botânicas foi usado o sistema de classificação APG II (Angiosperm Phylogeny Group - APG II, 2003), mais aceito atualmente entre a maioria dos pesquisadores da área.

A classe sucessional das espécies resgatadas (Budowski, 1965, Whitmore, 1982) foi definida por meio do conceito de pioneiras (agrupando as pioneiras e secundárias iniciais) e não-pioneiras (agrupando as secundárias tardias e climácicas) (Kageyama \& Gandara, 2004), mais freqüentemente utilizado em trabalhos práticos de restauração.

Durante o trabalho de revisão bibliográfica foram observadas diferenças na classificação sucessional de algumas espécies por diferentes autores. A inexistência de um consenso entre os pesquisadores (Barbosa, 2004; Kageyama \& Gandara, 2004) fez com que fossem consultados vários trabalhos (Gandolfi, 1991, Gandolfi et al., 1995; Gabriel, 1997; Albuquerque, 1999; Fundação Florestal, 2004) e assumida a classificação em que a espécie predominava. 


\subsubsection{Análises estatísticas}

As análises estatísticas foram realizadas visando à comparação de proporções obtidas nas duas épocas de resgate (julho e dezembro) e entre as classes de altura dos indivíduos resgatados.

Foram formuladas as seguintes hipóteses: A) O número de plantas resgatadas em julho (inverno) deveria ser significativamente diferente do número de plantas resgatadas em dezembro (verão); B) A porcentagem de plantas sobreviventes do resgate em julho (inverno) não deveria ser significativamente diferente da pocentagem de plantas sobreviventes do resgate em dezembro (verão); C) O número de plantas resgatadas na classe de altura $04-20 \mathrm{~cm}$ deveria ser significativamente diferente da classe de altura $21-40 \mathrm{~cm}$, que por sua vez seria significativamente diferente da classe de altura 41 - $60 \mathrm{~cm}$; D) A sobrevivência das plantas resgatadas deveria ser igual para as três classes de altura.

Em função da estrutura de aquisição de dados, aplicou-se o teste qui-quadrado (Zar, 1999) para comparação das proporções observadas nas diversas condições experimentais.

Para esse estudo foi assumido um nível de significância de $5 \%$. Os dados foram processados no programa SAS (SAS Institute Inc., 1999).

\subsection{Resultados e Discussão}

No total, foram resgatados em julho de 2002 (inverno), 774 indivíduos regenerantes em $200 \mathrm{~m}^{2}$, pertencentes a 48 espécies e 27 famílias. Estes valores foram bastante próximos do resgate reaslizado em dezembro de 2002 (verão), que apresentou 758 indivíduos regenerantes em $200 \mathrm{~m}^{2}$, pertencentes a 43 espécies e 19 famílias. Somando-se os dois levantamentos, foram resgatados 1532 indivíduos de espécies arbustivo-arbóreas em $400 \mathrm{~m}^{2}$, de 63 espécies arbustivo-arbóreas, considerando plântulas e indivíduos jovens, pertencentes a 28 famílias (Tabela 1 e 02). 
Tabela 1. Parâmetros gerais da comunidade de indivíduos arbóreos regenerantes resgatados nas duas épocas do ano (julho e dezembro de 2002)

\begin{tabular}{|c|c|c|c|c|}
\hline \multirow[t]{2}{*}{ Parâmetros } & \multicolumn{2}{|c|}{$\begin{array}{l}\text { Resgate - Julho } 2002 \\
\text { (inverno) }\end{array}$} & \multicolumn{2}{|c|}{$\begin{array}{c}\text { Resgate - Dezembro } 2002 \\
\text { (verão) }\end{array}$} \\
\hline & Campo & Sobrevivência & Campo & Sobrevivência \\
\hline $\mathrm{N}^{\circ}$. de indivíduos & 774 & 330 & 758 & 532 \\
\hline $\begin{array}{l}\text { Densidade total estimada } \\
\text { (ind./ha) }\end{array}$ & 38.700 & 16.500 & 37.900 & 26.600 \\
\hline $\mathrm{N}^{\circ}$. de espécies & 48 & 40 & 43 & 39 \\
\hline $\mathrm{N}^{\circ}$. de famílias & 27 & 25 & 19 & 19 \\
\hline $\begin{array}{l}N^{\circ} \text {. de espécies comuns } \\
\text { nas duas épocas }\end{array}$ & 28 & 23 & 28 & 23 \\
\hline $\begin{array}{l}\mathbf{N}^{0} \text {. de espécies exclusivas } \\
\text { nas duas épocas }\end{array}$ & 20 & 17 & 15 & 16 \\
\hline
\end{tabular}

A Figura 8 apresenta os resultados do teste de qui-quadrado para a classe de número de indivíduos nas duas épocas de coleta.

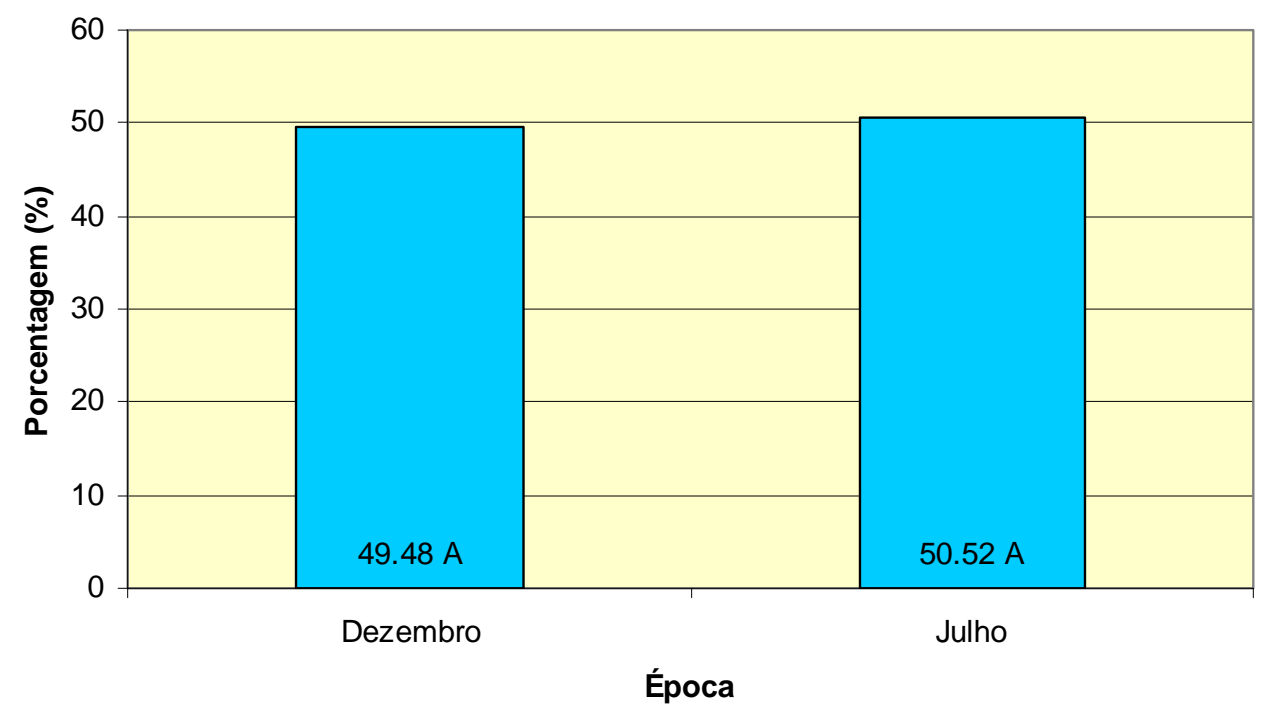

Figura 8 - Comparação de proporções de indivíduos resgatados em julho (inverno) e dezembro (verão) de 2002. Barras com letras iguais não diferem entre si pelo teste de quiquadrado com nível de significância alfa de 5\%

O teste de qui-quadrado não indica diferenças significativas entre as proporções do número de indivíduos resgatados nas épocas de dezembro (verão) e julho (inverno) de 2002. 
Tabela 2. Famílias e espécies pertencentes aos indivíduos arbóreos resgatados nas duas épocas de amostragens (julho e dezembro de 2002) no entorno da Mina Limeira, Cia de Cimento Ribeirão Grande, Município de Ribeirão Grande, SP. C.S. = Classe sucessional. P = Pioneiras; NP = Não pioneiras; Resg. = referente ao número de espécies encontradas nas parcelas de campo; Sobrev. = referente ao número de espécies sobreviventes no viveiro

\begin{tabular}{|c|c|c|c|c|c|c|}
\hline \multirow[t]{2}{*}{ Família } & \multirow[t]{2}{*}{ Espécie } & \multirow[t]{2}{*}{ C.S. } & \multicolumn{2}{|c|}{ Julho (inverno) } & \multicolumn{2}{|c|}{$\begin{array}{c}\text { Dezembro } \\
\text { (verão) }\end{array}$} \\
\hline & & & Resg. & Sobrev. & Resg. & Sobrev. \\
\hline Annonaceae & Rollinia sylvatica (A St.-Hil) Martius & NP & 5 & 3 & 2 & 2 \\
\hline Apocynaceae & Aspidosperma parvifolium A.DC. & NP & 1 & 1 & 0 & 0 \\
\hline Aquifoliaceae & Ilex cf taubertiana Loes & NP & 2 & 1 & 0 & 0 \\
\hline Arecaceae & Geonoma brevispatha Barb. Rodr. & NP & 26 & 12 & 5 & 2 \\
\hline Arecaceae & Euterpe edulis Mart. & NP & 0 & 0 & 1 & 0 \\
\hline Boraginaceae & Cordia ecalyculata Vell. & $\mathrm{P}$ & 2 & 2 & 0 & 0 \\
\hline Caesalpiniaceae & Copaifera langsdorffii Desf. & NP & 11 & 2 & 0 & 0 \\
\hline Caesalpiniaceae & Senna multijuga (Rich.)H.S. Irwin & $\mathrm{P}$ & 9 & 8 & 143 & 103 \\
\hline Caesalpiniaceae & Copaifera trapezifolia Hayne & NP & 0 & 0 & 7 & 4 \\
\hline Celastraceae & Maytenus robusta Reissek & NP & 15 & 5 & 16 & 13 \\
\hline Cercideae & Bauhinia forficata Link & $\mathrm{P}$ & 1 & 1 & 0 & 0 \\
\hline Elaeocarpaceae & Sloanea monosperma Vell. & NP & 1 & 1 & 0 & 0 \\
\hline Erythroxylaceae & Erythroxylon sp & NP & 11 & 6 & 34 & 28 \\
\hline Euphorbiaceae & Alchornea triplinervia (Spreng.) Müll. Arg. & $\mathrm{P}$ & 0 & 0 & 1 & 1 \\
\hline Euphorbiaceae & Sebastiania serrata (Baill.ex Müll. Arg.) & NP & 42 & 21 & 0 & 0 \\
\hline Euphorbiaceae & Croton floribundus Spreng. & $\mathrm{P}$ & 0 & 0 & 10 & 5 \\
\hline Euphorbiaceae & Croton lindenianus A. Rich. & $\mathrm{P}$ & 1 & 0 & 0 & 0 \\
\hline Fabaceae & Dalbergia frutescens (Vell.) Briton. & NP & 43 & 33 & 17 & 13 \\
\hline Fabaceae & Machaerium stipitatum D.C. Vogel & $\mathrm{P}$ & 2 & 1 & 0 & 0 \\
\hline Fabaceae & Machaerium scleroxylum Allemão & NP & 0 & 0 & 1 & 1 \\
\hline Fabaceae & Erithrina falcata Benth. & $\mathrm{P}$ & 0 & 0 & 1 & 1 \\
\hline Fabaceae & Zollernia ilicifolia (Brongn.) Vogel & NP & 0 & 0 & 20 & 17 \\
\hline Lauraceae & Ocotea dispersa (Nees) Mez & NP & 70 & 46 & 51 & 35 \\
\hline Lauraceae & Nectandra leucantha Griseb. & NP & 15 & 3 & 22 & 15 \\
\hline Lauraceae & Nectandra megapotamica Rol. Ex Rottb. & $\mathrm{P}$ & 3 & 2 & 6 & 6 \\
\hline Lauraceae & Endlicheria paniculata (Spreng.) J.F. Marcbr. & NP & 4 & 0 & 15 & 11 \\
\hline Lauraceae & Ocotea corymbosa (Meisn.) Mez. & NP & 124 & 42 & 1 & 0 \\
\hline Lauraceae & Ocotea sp 1 & NP & 0 & 0 & 4 & 2 \\
\hline Loganiaceae & Strychnos brasiliensis (Spreng.) Mart. & NP & 11 & 9 & 25 & 24 \\
\hline Melastomataceae & Tibouchina pulchra (Cham.) Cogn. & $\mathrm{P}$ & 7 & 1 & 0 & 0 \\
\hline Melastomataceae & Miconia sp 1 & $\mathrm{P}$ & 0 & 0 & 4 & 1 \\
\hline Melastomataceae & Miconia sp 2 & $\mathrm{P}$ & 3 & 0 & 5 & 0 \\
\hline Meliaceae & Cedrela fissilis Vell. & NP & 2 & 2 & 1 & 0 \\
\hline Meliaceae & Trichilia $s p$ & NP & 1 & 1 & 5 & 3 \\
\hline Meliaceae & Cabralea canjerana (Vell.) Mart. & NP & 1 & 1 & 0 & 0 \\
\hline Meliaceae & Trichilia pallida $\mathrm{Sw}$. & NP & 0 & 0 & 3 & 2 \\
\hline Mimosaceae & Inga sessilis (Vell.) Mart. & NP & 0 & 0 & 4 & 4 \\
\hline Mimosaceae & Piptadenia paniculata Benth. & $\mathrm{P}$ & 18 & 7 & 1 & 1 \\
\hline Mimosaceae & Piptadenia gonoacantha (mart.) J.F. & $P$ & 1 & 1 & 0 & 0 \\
\hline Monimiaceae & Mollinedia widgrenii A. DC. & NP & 15 & 10 & 46 & 43 \\
\hline Moraceae & Sorocea bonplandii (Baillon)Burg. & NP & 17 & 6 & 19 & 13 \\
\hline Myrsinaceae & Rapanea umbellata (Mart.)Mez & $\mathrm{P}$ & 7 & 5 & 4 & 3 \\
\hline Myrsinaceae & Rapanea ferruginea (Ruiz\&Pav.) Mez & $\mathrm{P}$ & 4 & 3 & 22 & 18 \\
\hline Myrsinaceae & Rapanea guianensis Aubl. & $\mathrm{P}$ & 0 & 0 & 1 & 1 \\
\hline
\end{tabular}


Tabela 2. Famílias e espécies pertencentes aos indivíduos arbóreos resgatados nas duas épocas de amostragens (julho e dezembro de 2002) no entorno da Mina Limeira, Cia de Cimento Ribeirão Grande, Município de Ribeirão Grande, SP. C.S. = Classe sucessional. P = Pioneiras; NP = Não pioneiras; Resg. = referente ao número de espécies encontradas nas parcelas de campo; Sobrev. = referente ao número de espécies sobreviventes no viveiro

\begin{tabular}{|c|c|c|c|c|c|c|}
\hline \multirow[t]{2}{*}{ Família } & \multirow[t]{2}{*}{ Espécie } & \multirow[t]{2}{*}{ C.S. } & \multicolumn{2}{|c|}{ Julho (inverno) } & \multicolumn{2}{|c|}{$\begin{array}{c}\text { Dezembro } \\
\text { (verão) }\end{array}$} \\
\hline & & & Resg. & Sobrev. & Resg. & Sobrev. \\
\hline Myrtaceae & Eugenia sp 1 & NP & 0 & 0 & 11 & 8 \\
\hline Myrtaceae & Psidium cattleianum Sabine & NP & 1 & 1 & 1 & 1 \\
\hline Myrtaceae & Myrcia fallax (Rich.) DC. & NP & 28 & 10 & 29 & 24 \\
\hline Myrtaceae & Myrtaceae 2 & NP & 6 & 1 & 0 & 0 \\
\hline Myrtaceae & Eugenia pluriflora D.C. & NP & 5 & 0 & 0 & 0 \\
\hline Myrtaceae & Gomidesia sp 1 & NP & 1 & 0 & 2 & 2 \\
\hline Myrtaceae & Gomidesia sp 2 & NP & 2 & 0 & 0 & 0 \\
\hline Myrtaceae & Myrtaceae 1 & NP & 0 & 0 & 90 & 58 \\
\hline Myrtaceae & Campomanesia guaviroba (D.C.)Kiaersk & NP & 3 & 2 & 8 & 8 \\
\hline Nyctaginaceae & Guapira opposita (Vell.) Reitz & NP & 0 & 0 & 7 & 6 \\
\hline Rosaceae & Prunus myrtifolia (L.) Urb. & $\mathrm{P}$ & 111 & 34 & 14 & 9 \\
\hline Rutaceae & Esenbeckia grandiflora Mart. & NP & 5 & 2 & 0 & 0 \\
\hline Rutaceae & Zanthoxylun rhoifolium Lam. & $\mathrm{P}$ & 4 & 2 & 0 & 0 \\
\hline Sapindaceae & Matayba guianensis Aubl. & NP & 25 & 7 & 16 & 6 \\
\hline Sapindaceae & Cupania vernalis Camb. & NP & 98 & 29 & 69 & 25 \\
\hline Sapindaceae & Allophylus edulis (A St.-Hill., Cambess\& A Juss) & NP & 6 & 5 & 14 & 13 \\
\hline Solanaceae & Solanum argenteum Dunal & NP & 1 & 1 & 0 & 0 \\
\hline Styracaceae & Styrax acuminatus Pohl. & NP & 2 & 0 & 0 & 0 \\
\hline Vochysiaceae & Vochysia tucanorum Mart. & $\mathrm{P}$ & 1 & 0 & 0 & 0 \\
\hline TOTAL & & & 774 & 330 & 758 & 532 \\
\hline
\end{tabular}

Entre as espécies amostradas, 31,7\% pertenciam ao grupo das pioneiras (espécies iniciais de sucessão - pioneiras e secundárias iniciais) e 68,3 \% pertenciam ao grupo das não-pioneiras (espécies finais de sucessão - secundárias tardias e climáx). Essa proporção entre as classes sucessionais das plântulas e indivíduos jovens resgatados, diferiu bastante da encontrada entre os indivíduos regenerados do banco de sementes originado do mesmo local (Capítulo 4), onde as espécies iniciais de sucessão representaram 77,8\% e as espécies finais de sucessão representaram 22,2\%.

Esses valores refletiram as características das espécies iniciais de sucessão que predominaram no banco de sementes persistentes do solo (Mantovani, 1994), aguardando um estímulo, como a presença de luz na abertura de clareiras, para sua germinação e desenvolvimento (Grombone \& Rodrigues, 2002). Por outro lado, as espécies finais de sucessão apresentam-se preferencialmente na forma de banco de 
plântulas e/ou indivíduos jovens (Ferretti et al.,1995; Kageyama \& Gandara, 2004; Martins \& Rodrigues, 2002).

Das 63 espécies resgatadas nas diferentes épocas (julho e dezembro de 2002), apenas $28(43,8 \%)$ eram comuns aos dois levantamentos. Estas 28 espécies comuns poderiam fazer parte de um banco de plantas persistentes na floresta, enquanto as outras poderiam estar apenas temporariamente no local.

Do total de indivíduos resgatados em julho (774), 330 (42,6\%) ficaram como sobreviventes em viveiro, os quais pertenciam a 40 espécies e 25 famílias. Esses valores foram siginificativamente menores que os indivíduos de espécies arbustivo-arbóreas resgatados em dezembro (verão) de 2002 (758) que apresentaram 532 (70,2\%) indivíduos sobreviventes em viveiro, pertencendo a 39 espécies e 19 famílias.

A Figura 9 apresenta o gráfico com os resultados estatísticos comparando a sobrevivência nas diferentes épocas do ano.

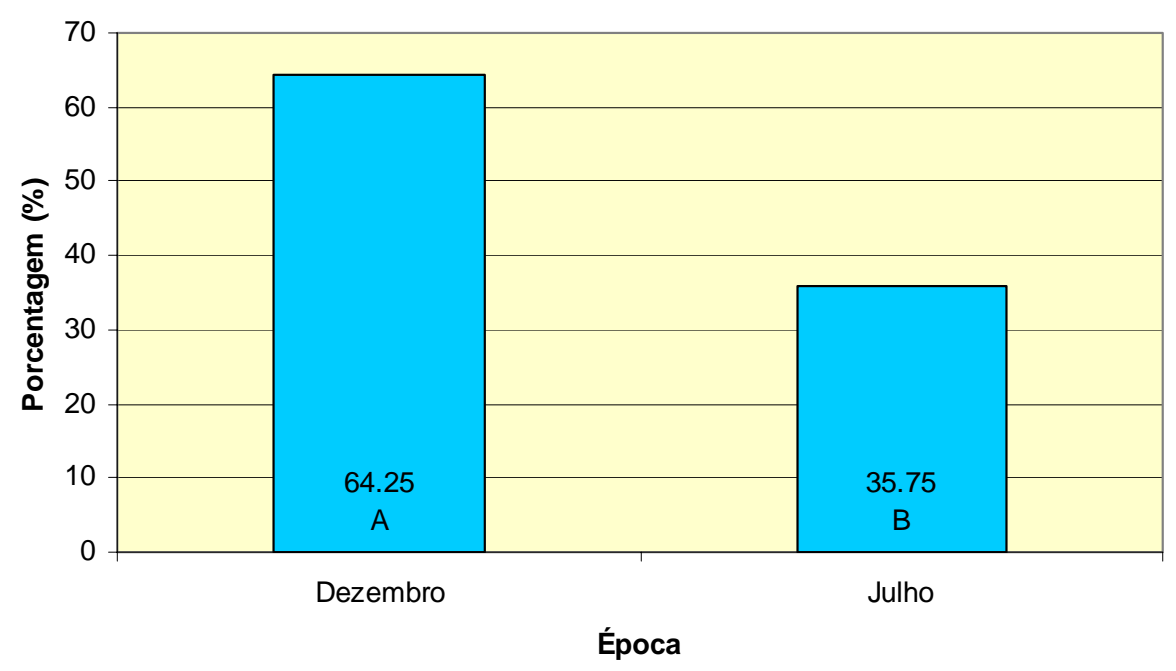

Figura 9 - Comparação de proporções de indivíduos sobreviventes em julho (inverno) e dezembro (verão) de 2002. Barras com letras iguais não diferem entre si pelo teste de qui-quadrado com nível de significância alfa de 5\%

Essa elevada diferença de sobrevivência entre as plantas resgatadas em duas diferentes épocas do ano (verão e inverno), provavelmente está relacionada às taxas de metabolismo das espécies nos dois períodos estudados. O viveiro para onde foram 
levadas as plantas resgatadas, localizado no Parque Intervales, apresenta invernos bastante rigorosos, com temperaturas médias inferiores a $18^{\circ} \mathrm{C}$ no mês mais frio e verões amenos com temperaturas médias inferiores a $22^{\circ} \mathrm{C}$ no mês mais quente. Cabe ressaltar que neste mesmo inverno de 2002, houve fortes geadas na região, que ocorreram semanas após o resgate das plântulas na floresta e transplante no viveiro devendo isso ter sido a principal causa de mortalidade.

A Tabela 3 apresenta os resultados do número de indivíduos resgatados em campo e as taxas de sobrevivência por classes de altura.

Nas duas avaliações constatou-se elevada quantidade de indivíduos resgatados na primeira classe de altura (4 a $20 \mathrm{~cm}$ ), totalizando 76,1\% e 67,8\% para julho (inverno) e dezembro (verão) de 2002, respectivamente. A classe de altura de 21 a $40 \mathrm{~cm}$, embora com valores menores que a anterior, foi bastante representativa com $18,9 \%$ e $27,2 \%$ do total de indivíduos amostrados para julho (inverno) e dezembro (verão) de 2002, respectivamente. Poucos indivíduos se apresentaram na classe de altura de 41 a $60 \mathrm{~cm}$ de altura, sendo $4,9 \%$ e $6,1 \%$ do total de indivíduos resgatados em julho (inverno) e dezembro (verão) de 2002, respectivamente. Esses resultados revelam que durante o período de estudo, a grande maioria dos indivíduos de espécies arbustivo-arbóreas regenerantes concentrou-se com até $40 \mathrm{~cm}$ de altura, somando $95 \%$ e $94 \%$ do total de indivíduos amostrados para julho (inverno) e dezembro (verão) de 2002, respectivamente (Figura 10).

Tabela 3. Número de indivíduos resgatados e taxa de mortalidade por classes de altura do resgate de indivíduos arbóreos regenerantes realizado em julho (inverno) e dezembro (verão) de 2002 na Mina Limeira, CCRG, Município de Ribeirão Grande SP

\begin{tabular}{lccccc}
\hline Época & $\begin{array}{c}\text { Classes de } \\
\text { altura (cm) }\end{array}$ & $\begin{array}{c}\mathbf{N}^{\mathbf{0}} \text { de ind. } \\
\text { resgatados }\end{array}$ & $\begin{array}{c}\text { \% de ind. } \\
\text { resgatados }\end{array}$ & $\mathbf{N}^{\mathbf{0}}$ de ind. vivos & $\begin{array}{c}\text { \% de ind. } \\
\text { vivos }\end{array}$ \\
\hline Julho & $4-20$ & 590 & 76,1 & 260 & 44,1 \\
(inverno) & $21-40$ & 146 & 18,9 & 59 & 40,4 \\
& $41-60$ & 38 & 4,9 & 11 & 28,9 \\
& Total & 774 & 100 & 330 & 42,6 \\
Dezembro & $4-20$ & 506 & 66,8 & 359 & 70,9 \\
(verão) & $21-40$ & 206 & 27,2 & 144 & 69,9 \\
& $41-60$ & 46 & 6,1 & 29 & 63,0 \\
& Total & 758 & 100 & 532 & 70,2 \\
\hline
\end{tabular}


A Figura 10 apresenta os resultados do teste de qui-quadrado para as classes de altura nas duas épocas de coleta.

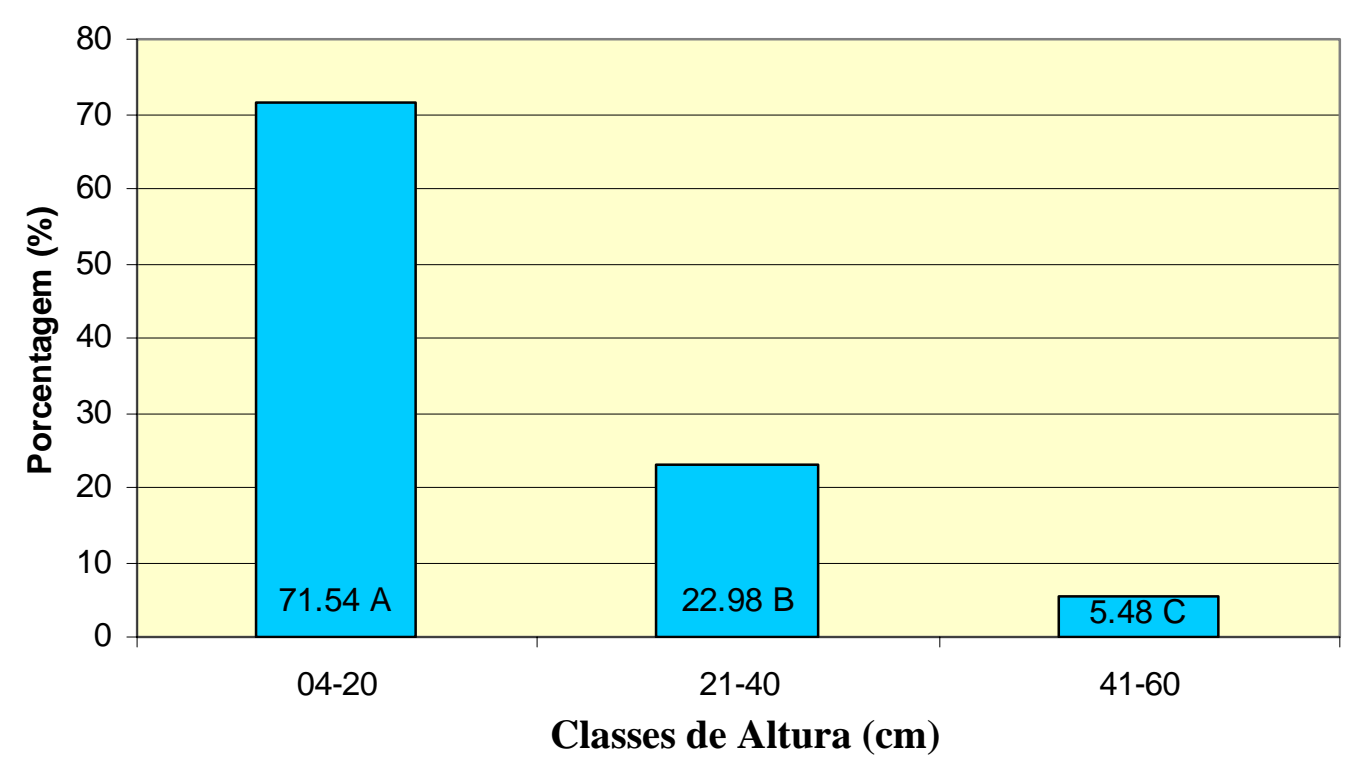

Figura 10 - Comparação de proporções de indivíduos resgatados nas três classes de altura. Barras com letras iguais não diferem entre si pelo teste de quiquadrado com nível de significância alfa de 5\%

No entanto, quando analisamos os resultados da taxa de sobrevivência por classe de altura, podemos notar que para as duas épocas de amostragens, a taxa diminuiu com as maiores classes de altura dos indivíduos resgatados. Para o resgate de julho (inverno) de 2002 estes valores variaram de 44,1\%, 40,4\% e 28,9\%, sendo que para dezembro (verão) estes valores variaram de 70,9\%,69,9\% e 63,0\% para as classes de 4 a $20 \mathrm{~cm}, 21$ a $40 \mathrm{~cm}$ e 41 a $60 \mathrm{~cm}$, respectivamente (Tabela 3). Esse aumento na mortalidade em função do aumento da altura, provavelmente está relacionado com o maior dano radicular dos indivíduos de maior porte no momento do resgate, provocando um desequilíbrio hídrico na planta que perde mais água do que suas raízes danificadas são capazes de absorver do solo (Thoma, 1998). Entretanto, as análises estatísticas não indicaram diferenças sigificativas da taxa de sobrevivência entre as classes de altura (Figura 11). 


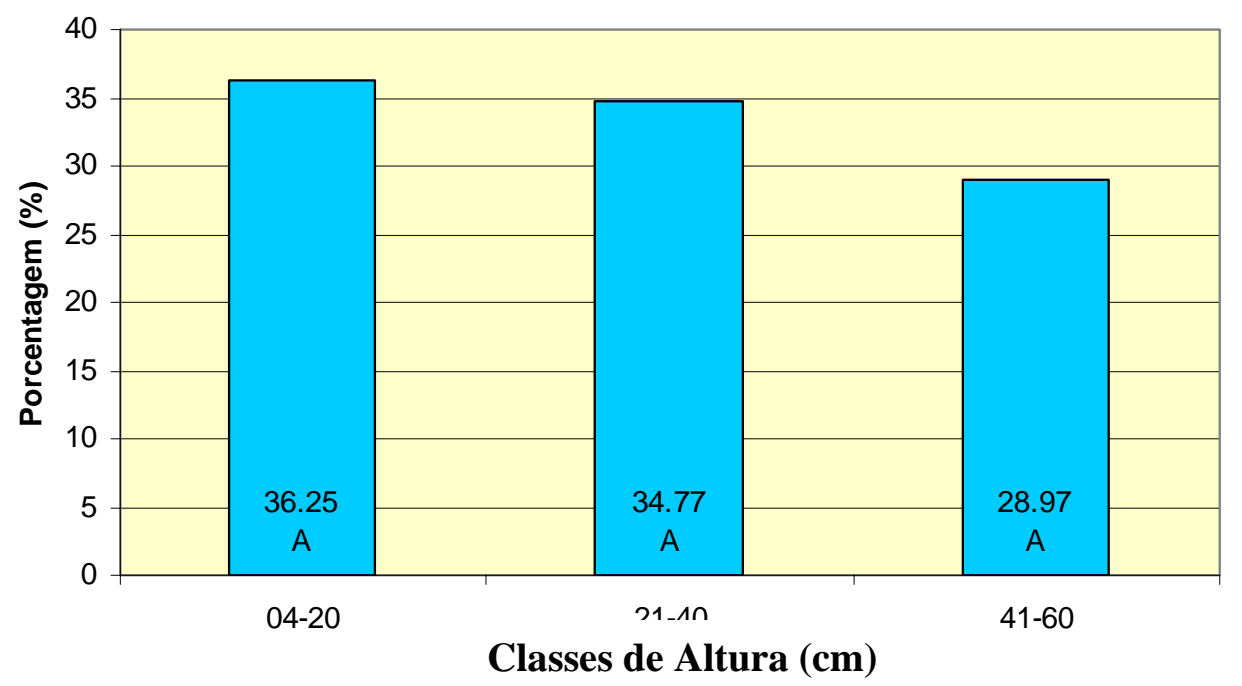

Figura 11 - Comparação de proporções de indivíduos sobreviventes nas três classes altura. Barras com letras iguais não diferem entre si pelo teste de quiquadrado com nível de significância alfa de 5\%

O teste permite observar que a freqüência de sobrevivência da classe 04-20 é pouco superior às outras duas classes, já que podem ser encontrados $36,24 \%$ dos dados nesta categoria. Esta proporção não diferiu significativamente das observadas nas outras categorias de classes. A proporção de indivíduos sobreviventes da classe de diâmetro entre 41-60 é pouco inferior às demais com $28,97 \%$ dos dados.

As taxas médias de sobrevivência, considerando todas as classes de altura, foram de $42,6 \%$ para o resgate realizado em julho (inverno) de 2002 e 70,2\% para o resgate realizado em dezembro (verão) de 2002. Entretanto, os dados não permitiram relacionar as taxas de sobrevivência com espécies ou famílias individualmente, em função do número de indivíduos resgatados, apesar de existir essa probabilidade. A observação em viveiro de saturação hídrica (encharcamento), nos recepientes das mudas, levanta a hipótese de uma parte da mortalidade estar relacionada à drenagem do substrato. Assim, provavelmente uma composição melhor do substrato, que possibilite uma boa drenagem, poderá propiciar uma maior sobrevivência das plantas resgatadas. 
O melhor resultado de resgate de plântulas e indivíduos jovens arbustivoarbóreos ocorreu com o resgate realizado de dezembro (verão) de 2002 para a classe de altura de $04 \mathrm{~cm}$ a $20 \mathrm{~cm}$, a qual obteve 70,9\% de sobrevivência (Tabela 3), contrariando o trabalho de Seitz (1996), que sugere a utilização de indivíduos jovens com mais de 20 $\mathrm{cm}$ de altura. Thoma (1998) relata que quanto maior a muda, maior é o prejuízo ao sistema radicular das mesmas durante o transplante.

A dissertação de mestrado de Viani (no prelo), em fase final de redação, mostrou resultados muito próximos aos deste trabalho, o melhor com índice de 69,11\% de sobrevivência para coletas realizadas em abril e junho de 2003, utilizando Plantimax como substrato dos indivíduos resgatados. Já no trabalho de Pareja (1998), usando a mesma técnica, o autor conseguiu $72 \%$ de sobrevivência para a Ocotea spixiana e $48 \%$ para Emmotum nitens, mostrando diferenças significativas entre espécies da mesma formação.

As informações obtidas nas classes de altura dos indivíduos de espécies arbustivo-arbóreas regenerantes nos permitiram concluir que, para a região estudada, os melhores resultados de resgate podem ser obtidos nos meses mais quentes do ano, com a seleção de indivíduos com altura entre 04 e $40 \mathrm{~cm}$. Entretanto, ficou claro que o banco de plântulas e indivíduos jovens regenerantes apresentaram diferenças florísticas significativas, dependendo da época do ano. A Tabela 2 mostra que de 63 espécies resgatadas nas duas avaliações (julho e dezembro de 2002), apenas 56 espécies tiveram indivíduos sobreviventes no experimento, esse número cairia para 40 se fosse em apenas uma das épocas escolhidas. O resgate nas duas épocas do ano possibilita um aumento da diversidade, que é uma das premissas da restauração ecológica (Pickett et al., 1987). Nesse sentido, a melhoria das técnicas de resgate, como por exemplo: a implantação de estufas no viveiro pra proteção das mudas resgatadas, em relação à queda brusca de temperatura; a determinação das classes de altura com maior sobrevivência e; a elaboração de substrato específico; poderão contornar o problema da baixa sobrevivência no inverno, permitindo resgates bem sucedidos ao longo do ano. Em regiões onde o inverno é ameno, esta técnica pode ser usada sem maiores restrições. 
Certamente as taxas de mortalidade poderão ser fortemente reduzidas com o avanço do conhecimento sobre as técnicas de resgate. Se todos os indivíduos resgatados sobrevivessem estaríamos tratando de valores estimados de 38.700 e 37.900 ind./ha, para os meses de julho (inverno) e dezembro (verão), respectivamente. Ressaltamos que foram analisados apenas os dados referentes às espécies arbustivo-arbóreas e que as mesmas devem representar apenas 45 a 50\% do total de indivíduos vegetais nas suas várias formas de vida (Reis, 1996, Ivanauskas et al., 2001). Dentro deste contexto, não só a densidade de indivíduos resgatados, mas também, o número de espécies poderia alcançar valores bem mais elevados.

Em comparação ao método tradicional de coleta de sementes, o transplante de mudas resgatadas dispensa as etapas de coleta de sementes, beneficiamento, armazenamento, germinação e desenvolvimento da plântula até o tamanho ideal para sua repicagem. Estas etapas geralmente são complicadas e onerosas, devido à falta de informações básicas como localização das matrizes, ponto de maturação dos frutos, técnicas de beneficiamento, armazenamento e quebra de dormência (Corvello, 1983; Thoma, 1998). Isso faz com que a diversidade de espécies encontradas na maioria dos viveiros, ainda seja muito abaixo da exigida pela legislação (Resolução SMA 47).

Entretanto, não basta o aumento da riqueza de espécies usadas nos projetos de restauração, é necessária a busca do incremento de diferentes genótipos, aumentando as possibilidades de sucessão ecológica em função da heterogeneidade das áreas a serem recuperadas. Da mesma forma como é realizado para a coleta de sementes (Kageyama \& Gandara, 2004), acreditamos que deve-se resgatar as plântulas ou indivíduos regenerantes oriundas de no mínimo 12 a 13 matrizes diferentes em fragmentos relativamente bem conservados, com uma população de pelo menos 500 indivíduos. Com isso, espera-se que essa coleta seja representativa de aproximadamente 50 indivíduos $\left(\mathrm{N}_{\mathrm{e}}=\right.$ tamanho efetivo $\left.=50\right)$, o que garantirá uma amostra genética representativa da população. Provavelmente isso possa ser realizado na prática da mesma forma que é recomendado para matrizes de sementes, ou seja, realizando o resgate de uma mesma espécie em vários fragmentos ou com uma distância relativamente grande entre os locais de resgate num mesmo fragmento. Assim, a 
viabilidade desta proposta ainda tem que ser confirmada por meio de estudos genéticos dos indivíduos resgatados.

As Figuras 12, 13, 14 e 15 apresentam as 10 espécies mais representativos, definidas neste trabalho pela soma da densidade relativa e freqüência relativa, para cada etapa (campo e viveiro) nas duas épocas de amostragens (julho e dezembro de 2002).

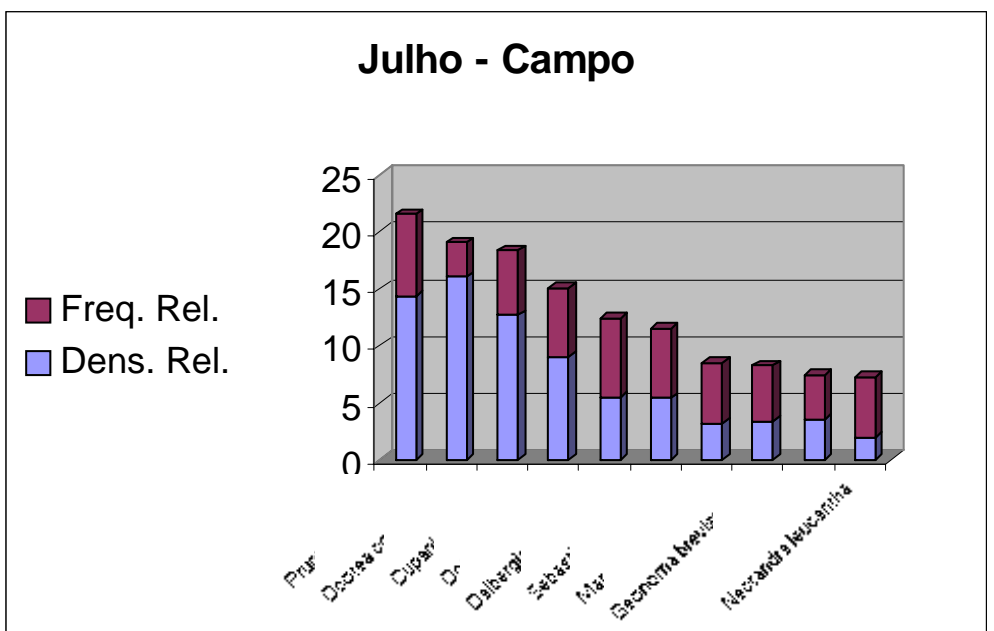

Figura 12 - Distribuição dos valores de densidade relativa (Dens. Rel.) e freqüência relativa (Freq. Rel.) por espécies nas amostras de campo realizadas em julho (inverno) de 2002 na Mina Limeira, Cia. de Cimento Ribeirão Grande, Município de Ribeirão Grande SP

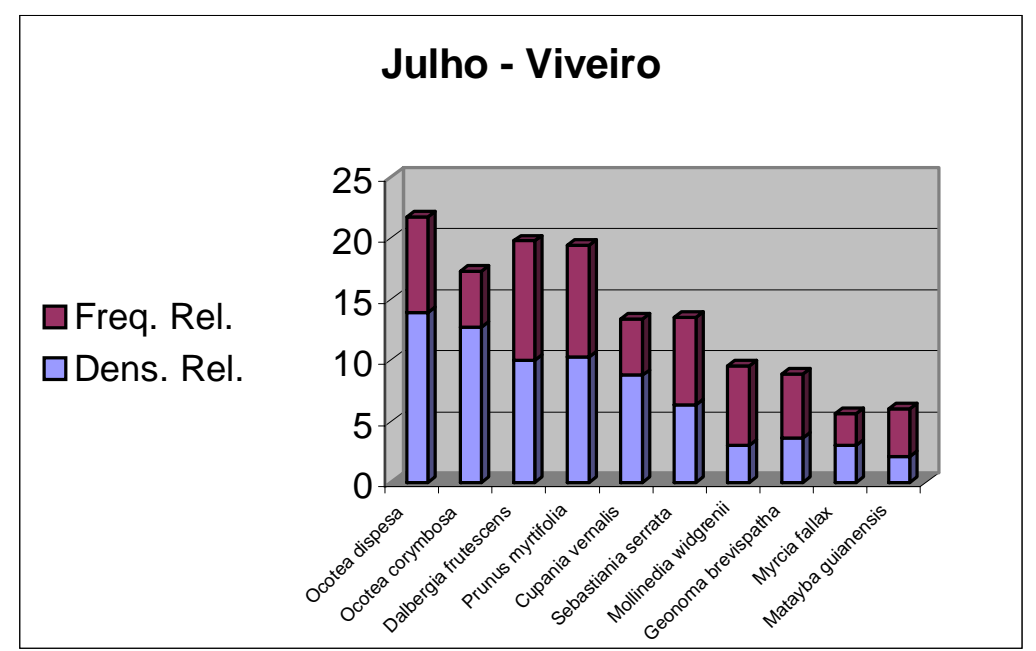

Figura 13 - Distribuição dos valores de densidade relativa (Dens. Rel.) e freqüência relativa (Freq. Rel.) por espécies nas amostras de viveiro referente às coletas realizadas em julho (inverno) de 2002 na Mina Limeira, CCRG, Município de Ribeirão Grande SP 


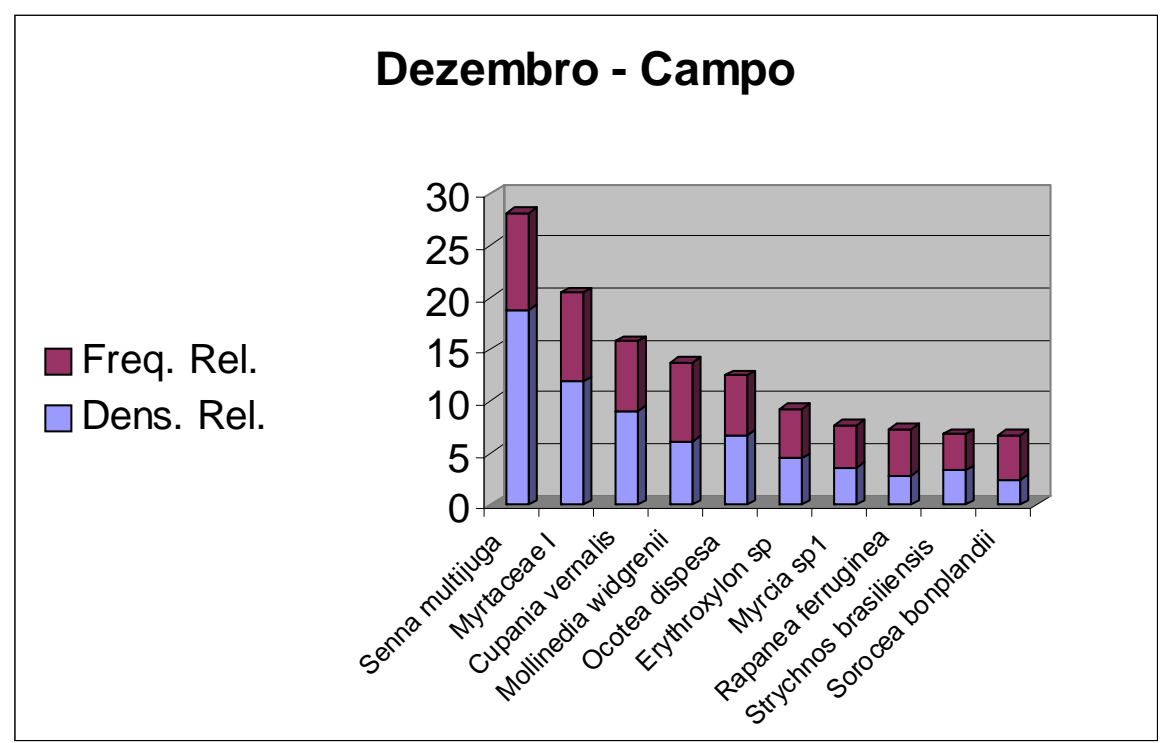

Figura 14 - Distribuição dos valores de densidade relativa (Dens. Rel.) e freqüência relativa (Freq. Rel.) por espécies nas amostras de campo realizadas em dezembro (verão) de 2002 na Mina Limeira, CCRG, Município de Ribeirão Grande SP

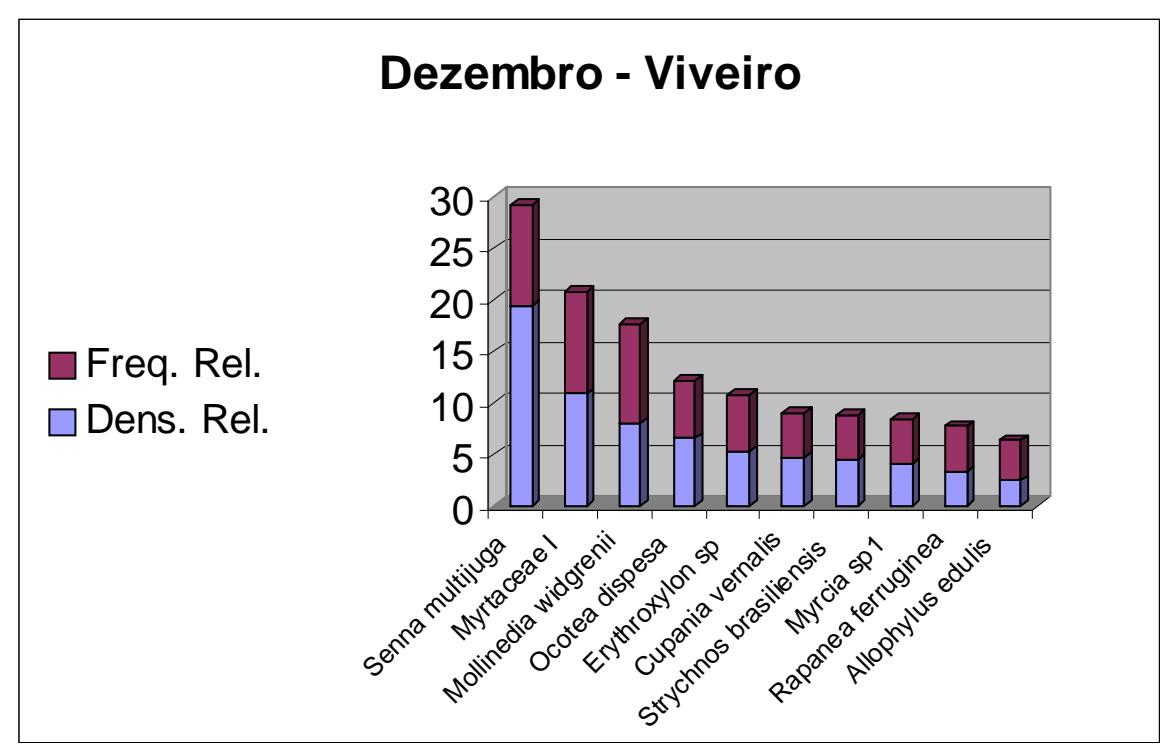

Figura 15 - Distribuição dos valores de densidade relativa (Dens. Rel.) e freqüência relativa (Freq. Rel.) por espécies nas amostras de viveiro referente às coletas realizadas em dezembro (verão) de 2002 na Mina Limeira, CCRG, Município de Ribeirão Grande SP 
A Tabela 4 apresenta a soma da densidade relativa das 10 espécies mais representativas, em cada uma das quatro situações de analisadas. Os resultados mostram que de 48 espécies resgatadas em julho (inverno), as 10 mais representativas representaram 75,2\% do total resgatado. Para essa mesma época de julho (inverno), das 40 espécies sobreviventes, as 10 mais representativas representaram $73,9 \%$ do total. No mês de dezembro (verão), das 44 espécies resgatadas e 40 sobreviventes, as 10 mais representativas representaram $69,4 \%$ do total, nos dois casos. Isso mostra que nas áreas estudadas e nas diferentes épocas, não havia uma proporção semelhante de densidade entre os indivíduos de cada espécie. No entanto, das 10 espécies mais representativas nas duas épocas, apenas 3 espécies são comuns: Ocotea dispersa, Mollinedia widgrenii e Cupania vernalis. Assim, provavelmente exista uma alteração da maioria das espécies mais representativas ao longo do ano, que pode ocorrer devido a competição, a predação, estresse hídrico em períodos de estiagem ou até mesmo alguns eventos naturais como frio intenso, tempestades, etc. (Nepstad et al., 1998; Pareja, 1998). Essa hipótese reforça a importância do resgate em duas ou várias épocas do ano, como prática complementar de produção em viveiros de espécies nativas.

Tabela 4. Soma da densidade relativa das 10 espécies mais representativas, nas diferentes situações analisadas

\begin{tabular}{ccccc}
\hline \multirow{2}{*}{ Época } & \multicolumn{2}{c}{ Resgate } & \multicolumn{2}{c}{ Sobrevivência } \\
& Jul & Dez & Jul & Dez \\
\hline $\begin{array}{c}\text { Densidade } \\
\text { Relativa (\%) }\end{array}$ & \multirow{2}{*}{75,2} & 69,4 & 73,94 & 69,4 \\
\hline
\end{tabular}

No entanto, deve ser ressaltado que a maioria das espécies consideradas mais representativas geralmente é de baixa produção em viveiros florestais, pela dificuldade de coleta de suas sementes ou pela falta de tecnologia para sua produção, dificultando seu uso em sistemas de restauração de alta diversidade (Crestana, 1993). Seu aproveitamento por meio do resgate irá aumentar e complementar a diversidade de espécies produzidas nos viveiros, uma vez que a maioria dessas espécies sobreviveu ao resgate. 


\subsection{Conclusões}

- Atualmente, o uso da técnica de resgate de plantas só é permitido em remanescentes florestais que, por algum motivo, serão suprimidos. Essa técnica de resgate não deve ser usada indiscriminadamente em florestas naturais, a fim de permitir a continuidade dos processos de seleção e dinâmica do fragmento envolvido, devendo sim, ser usada como técnica complementar da produção oriunda de sementes, visando o aumento da diversidade em viveiros. $\mathrm{O}$ resgate em formações florestais remanescentes ainda precisa ser devidamente estudado em trabalhos científicos que tratem da dinâmica de regeneração.

- A densidade dos indivíduos resgatados foi muito próxima para as duas épocas do ano, sendo 38.700 ind./ha e 37.900 ind./ha, mas com uma diferença significante para os indivíduos sobreviventes no viveiro que apresentaram 16.500 ind./ha e 26.600 ind./ha para os meses de julho (inverno) e dezembro (verão) de 2002, respectivamente.

- A técnica utilizada, de resgate de plântulas e indivíduos de espécies arbustivoarbóreas regenerantes, se mostrou viável uma vez que foi possível alcançar até $70,9 \%$ de sobrevivência para os indivíduos resgatados em dezembro (verão) de 2002, com altura entre 04 e $20 \mathrm{~cm}$. Enquanto que para os indivíduos resgatados em julho (inverno) de 2002, o melhor resultado foi $44,1 \%$ de sobrevivência também para a classe de altura entre 04 e $20 \mathrm{~cm}$.

- As plântulas ou indivíduos juvenis contendo pelo menos duas folhas bem desenvolvidas e medindo entre $04 \mathrm{~cm}$ até $40 \mathrm{~cm}$ de altura se mostraram com as maiores taxas de pegamento e de densidade. Indivíduos com porte acima deste, exigem grande esforço para a sua retirada como a poda drástica de suas raízes, causando problemas de espaço no transporte e baixa sobrevivência, aumentando o custo de sua utilização na recuperação de áreas degradadas.

- As informações obtidas nos resgates permitiram concluir, para a região estudada, que os melhores resultados de resgate podem ser obtidos nos meses mais quentes do ano. 
Entretanto, ficou claro que o banco de plântulas e indivíduos jovens regenerantes apresenta diferenças florísticas bastante significativas, dependendo da época do ano.

- Além do resgate de plântulas e indivíduos jovens, esse método é de grande importância para permitir o resgate da diversidade genética local, onde a vegetação nativa será suprimida. Portanto, deve ser recomendado principalmente em empreendimentos com áreas que serão desmatadas, como forma de medida mitigadora dos impactos gerados, usando os propágulos resgatados preferencialmente na própria região ou como estratégia de conservação da diversidade genética.

- Considerando que os indivíduos de espécies arbustivo-arbóreas representam apenas cerca de 45 a $50 \%$ do total de indivíduos encontrados em uma floresta (Reis, 1996, Ivanauskas et al., 2001), esta técnica pode ser expandida para as outras formas de vida como epífitas, lianas não agressivas e herbáceas, as quais também fazem parte da dinâmica florestal, garantindo a continuidade dos processos ecológicos na área restaurada. 


\section{COMBINAÇÃO DAS ESPÉCIES EM GRUPOS DE PREENCHIMENTO E DIVERSIDADE, COMO METODOLOGIA DE RESTAURAÇÃO FLORESTAL NATIVA}

\section{Resumo}

A escolha ou criação de um modelo de restauração é um processo em constante aprimoramento, exigindo a necessidade de estudos que não apenas diminuam os custos envolvidos, mas também, que garantam a efetividade do objetivo proposto. Este trabalho visa testar um modelo de restauração desenvolvido pelo Laboratório de Ecologia e Restauração Florestal (LERF - ESALQ/USP), usando conceitos de "Grupos de Preenchimento" e de "Grupos de Diversidade". Os grupos de plantio foram implantados na forma de modelos de linhas alternadas, apresentando espaçamento de $3 \mathrm{~m}$ entre elas e $2 \mathrm{~m}$ entre plantas na mesma linha. As medições de cobertura de copa, obtidas pelo diâmetro da largura da copa no sentido da linha de plantio, foram realizadas em 2 comunidades diferentes, sendo uma num reflorestamento com 1,5 anos e outra num reflorestamento com 2,5 anos. A coleta dos dados foi realizada no mês de julho de 2004, pela medição das copas dos indivíduos plantados através da sua projeção vertical sobre trena. As medições foram realizadas em 15 transectos de 100 metros, em cada uma das linhas dos diferentes grupos de plantio. Com os dados de cobertura média da copa dos indivíduos de cada grupo, foi possível realizar uma simulação com diferentes modelos de plantio usando diferentes combinações de espaçamento e arranjo entre grupos. No total foram amostrados, nas duas idades de plantio, 2.787 indivíduos pertencentes a 143 espécies, sendo 35 espécies pertencentes ao grupo de Preenchimento e 108 espécies pertencentes ao grupo de Diversidade. Esses valores mostraram o estabelecimento de um número elevado de espécies, demonstrando que a função do grupo da diversidade vem 
sendo mantida. O grupo de Preenchimento apresentou-se com uma porcentagem de cobertura significativamente maior que a do grupo de Diversidade, cumprindo sua principal função no processo de restauração. Isso ocorreu tanto para o reflorestamento com a idade de 1,5 anos como para o reflorestamento com a idade de 2,5 anos, sendo que para 1,5 anos a diferença de cobertura foi de 73,6\% maior para o grupo de Preenchimento em relação ao grupo de Diversidade e para 2,5 anos essa diferença foi de $83,3 \%$. A simulação de modelos de plantio com diferentes arranjos, espaçamentos entre plantas e usando os parâmetros de cobertura média dos indivíduos dos dois grupos de plantio, mostrou que o modelo utilizado pode ser melhorado no sentido de diminuir a competição entre plantas, promovendo de forma mais eficaz, os processos sucessionais.

Summary

Choosing or elaborating a restoration model is a process that requires constant improvement and ecological studies that not only reduces the costs involved but also warrants the achievement of the aimed proposal. This study explores a new restoration methodology developed by the Forest Restoration and Ecology Laboratory (LERF ESALQ/USP), testing the efficiency of a planting model that uses "fulfillment" and "diversity" groups. These groups were established into alternated row models with $3 \mathrm{~m}$ apart and $2 \mathrm{~m}$ between plants in the same row. The crown measurements, obtained by the crown wide diameter along the row line, were taken at two different communities: a 1,5 and a 2,5 year-old reforested area. Data gathering was made in July 2004, by measuring the crown's vertical projection over a tape measure. Measurements were made in 15 transects of $100 \mathrm{~m}$ at every line planted with different groups. With the mean individual crown coverage data from each group, it was possible to make a simulation with different planting models using distinguished combinations of space between rows and group arrangements. The total sampling accounted 2.787 individuals belonging to 143 different species, which were 35 fulfilling species and 108 diversity species. The high number of established species demonstrates that the diversity group role has been maintained. The fulfilling group had a significant higher percentage of crown area than 
the diversity group, with $73,6 \%$ and $83,3 \%$ for 1,5 and 2,5 years respectively. The planting models simulation with different arrangements, distance between plants and mean crown area parameters for both studied groups demonstrated that the model used can be improved aiming competition decrease among plants, which can promote in a feasible way the successional processes.

\subsection{Introdução}

A recuperação de ecossistemas degradados é uma atividade muito antiga, podendo encontrar exemplos de sua existência na história de vários povos, em diferentes épocas e regiões (Rodrigues \& Gandolfi, 2004). Inicialmente, as atividades de recuperação eram usadas como uma prática de plantio de mudas, com objetivos muito específicos como controle da erosão, conservação de nascentes, paisagismo, estabilização de taludes, etc.

No Brasil, um dos primeiros trabalhos de restauração florestal foi iniciado em 1862, na atual Floresta Nacional da Tijuca no município do Rio de Janeiro, visando à preservação das nascentes e regularização do abastecimento público de água (Cézar \& Oliveira, 1992). Outro trabalho de grande importância iniciou-se no município de Cosmópolis em 1955, às margens do Rio Jaguari, utilizando-se 71 espécies arbustivoarbóreas, a maioria nativas, sem espaçamento definido entre as mudas plantadas (Nogueira, 1977). Esse reflorestamento foi finalizado em 1960, e segundo o autor, as espécies foram distribuídas de forma a não constituir grupos homogêneos. É importante ressaltar que, na época em que se deram essas primeiras iniciativas, não foram incorporados os conceitos de grupos ecológicos e nem o conhecimento sobre o papel da diversidade na restauração de áreas degradadas. No entanto, esses trabalhos tiveram grande sucesso nos seus objetivos, apresentando hoje uma floresta biodiversa e com suas funções e processos restaurados. Isso se deve principalmente ao processo de colonização dessas áreas com propágulos de espécies nativas vindos de remanescentes florestais no entorno, ao longo dessas dezenas de anos. 
Somente na década de 1980, com o desenvolvimento da ecologia da restauração como ciência (Engel \& Parrota, 2003), é que a recuperação de áreas degradadas vem sendo aplicada e definida metodologicamente como uma atividade vinculada às concepções teóricas (Rodrigues \& Gandolfi, 2004).

Com isso, nas últimas décadas, a ciência tem buscado aprimorar a metodologia de restauração florestal através do desenvolvimento de tecnologias de produção de mudas e sementes, de plantio, de combinação de mudas no campo (para uma maior eficiência no recobrimento da área), de outras metodologias de reintrodução de propágulos, sempre com objetivo da restauração dos processos ecológicos, restabelecendo o funcionamento da dinâmica florestal.

Nas décadas de 60 e 70, importantes trabalhos realizados por Budowski, (1965) e Whitmore (1976), baseados na dinâmica de florestas, introduziram a questão sucessional das espécies nativas, que culminou em grandes mudanças metodológicas nas atividades de restauração florestal (Crestana, 1992; Kageyama, 2001; Kageyama \& Gandara, 2004; Rodrigues \& Gandolfi, 2004; Barbosa, 2004). Em função disso, desde o final da década de 80 até os dias atuais, vários modelos de combinação de espécies de diferentes grupos sucessionais foram testados na restauração de áreas degradadas (Durigan \& Nogueira, 1990; Rodrigues et al., 1992; Macedo et al., 1993; Crestana et al., 1993; Rodrigues \& Gandolfi, 2004; Barbosa, 2004, entre outros).

Em 1987 foi proposto e implantado em Iracemápolis, o primeiro projeto que combinava o uso da sucessão ecológica, alta diversidade de espécies e predomínio de espécies exclusivamente regionais, respeitando inclusive, o tipo de formação florestal a ser recomposto (Crestana, 1993). Neste projeto foram usadas 106 espécies em sistema de módulos, combinando as espécies pioneiras, secundárias (iniciais e tardias) e climácicas. Como o modelo foi inicialmente baseado nos conceitos do Paradigma Clássico da Ecologia, as densidades dos indivíduos de cada espécie e sua distribuição espacial foram definidas com base na fitossociologia de florestas preservadas da região, buscando um clímax único (Pickettet al., 1992).

Em 1988 foi estabelecido um convênio entre a Companhia Energética do Estado de São Paulo (CESP) e a ESALQ/USP, visando melhorar os modelos de plantio de 
espécies nativas no entorno das represas de geração de energia. Esse convênio permitiu o avanço dos modelos de plantios de espécies nativas, usando a sucessão ecológica como fundamento básico (Kageyama \& Viana, 1989; Kageyama et al., 1990; Kageyama, 2003). Entretanto, esses modelos não expressavam uma preocupação maior com a diversidade de espécies (Souza \& Batista, 2004). Talvez isso também tenha ocorrido devido aos conceitos clássicos de ecologia dominantes na época, onde acreditava-se que os sistemas naturais eram considerados fechados e auto-reguláveis (Pickettet al., 1992; Pickett \& Ostfeld, 1994) e a sucessão era um processo determinístico, ocorrendo através da convergência de fases para atingir um clímax único. Clements $(1916,1928)$ e Odum (1969) relataram que os processos de sucessão ocorriam de forma ordenada, direcionada e previsível, controlada pela comunidade e principalmente convergindo para um clímax regional único dentro de um ecossistema estabilizado, com propriedades homeostáticas. Nesse ecossistema, a capacidade suporte de uma população seria fixa e constante.

Em todos esses modelos, usando grupos sucessionais, as espécies mais iniciais de sucessão tinham como objetivo principal o rápido sombreamento da área a ser restaurada (Rodrigues et al., 1987; 1992; Kageyama et al., 1990; 1994; Kageyama \& Gandara; 2004), criando um ambiente adequado para o desenvolvimento das espécies finais da sucessão.

Com o sucesso da introdução do conceito sucessional, possibilitando a implantação da fisionomia florestal em curto espaço de tempo, pelo uso de espécies pioneiras, aliado às dificuldades de obtenção de sementes das várias espécies finais de sucessão para uso em larga escala, a questão da diversidade foi deixada em segundo plano.

Em função disso, na década de 90, uma boa parte dos projetos de restauração adotou a relação de 2/3 dos indivíduos plantados de poucas espécies pioneiras (Barbosa, 2002), sem se preocupar com o ciclo de vida curto dessas espécies, com o número de espécies em cada um dos grupos ecológicos e com a diversidade total de espécies nos plantios. Isso teve como conseqüência uma senescência dos numerosos indivíduos plantados das poucas espécies iniciais de sucessão, concentrada nas primeiras décadas pós-plantio, sem criar condições necessárias para os indivíduos das espécies dos demais 
grupos ecológicos, plantadas em baixa diversidade, ocupassem essas aberturas geradas pela morte das pioneiras, favorecendo a recolonização da área restaurada por gramíneas exóticas invasoras e, consequentemente a mato-competição (Barbosa, 2002). Essa invasão de gramíneas exóticas nos reflorestamentos podem ter influenciado ou determinado a ausência de indivíduos regenerantes de espécies nativas no interior dessas áreas restauradas (Souza \& Batista, 2004), comprometendo ainda mais a diversidade e a restauração de processos ecológicos, que poderiam sustentar a perpetuação dessas áreas (Rodrigues \& Galdolfi, 2004).

As conseqüências do uso de baixa diversidade em médio prazo são descritas por Souza \& Batista (2004), em que os autores relatam que de 3 áreas restauradas pela CESP em 1988, 1989 e 1993 no Pontal do Paranapanema, a maior riqueza, diversidade, equabilidade, densidade de indivíduos em regeneração e recrutamento de outras formas de vida, foram obtidas pela única área implantada sem a utilização dos princípios de sucessão secundária, mas com um grande número de espécies.

Numa avaliação realizada pela Coordenadoria de Informações Técnicas, Documentação e Pesquisa Ambiental (CINP), da Secretaria de Estado do Meio Ambiente de São Paulo (SMA), ficou constatado uma situação preocupante em projetos de reflorestamento com espécies nativas implantadas em todo o Estado de São Paulo, em relação à perda da diversidade biológica e a crescente degradação desses reflorestamentos com espécies nativas nos últimos quinze anos (Barbosa, 2002). Nesse trabalho, o autor relata que, na maioria das áreas restauradas, utilizou-se em média 30 espécies apenas, geralmente as mesmas, sendo $2 / 3$ delas dos estágios iniciais da sucessão ecológica e, portanto, de ciclos de vida geralmente muito curtos (10-20 anos). As constatações que mostraram o uso de baixa diversidade florística das populações, levaram a Secretaria do Meio Ambiente (SMA) do Estado de São Paulo a editar a Resolução SMA 21, de 21/11/2001, alterada e substituída pela Resolução SMA 47, de 26 de novembro de 2003, a qual fixa número mínimo de espécies e número máximo de indivíduos nos grupos ecológicos para serem usados em projetos de restauração com nativas, além de outras inovações metodológicas. 
Nos últimos anos, as mudanças não só legislativas, mas também, metodológicas na área da ecologia de restauração têm sido baseadas no Paradigma Contemporâneo, também conhecido como Paradigma do não equilíbrio (Pickettet al., 1992) - A Natureza em Fluxo. Nesse Paradigma é aceita a teoria de que as mudanças sucessionais da vegetação podem ocorrer seguindo múltiplas trajetórias (Pickettet al., 1992), não existindo uma convergência nas mudanças do sistema para chegar a um "ponto clímax único". A incorporação desses conceitos nos trabalhos de restauração ecológica está proporcionando importantes alterações metodológicas.

De acordo com o Paradigma Contemporâneo são necessárias três condições básicas para que ocorram os processos de sucessão em uma área a ser restaurada: a) Disponibilidade de local adequado; b) Disponibilidade de diferentes espécies; c) Disponibilidade de diferentes performances entre as espécies (Pickett et al., 1987; Barbosa, 2004).

Assim, surgiu a necessidade de elaboração de uma metodologia baseada nos conceitos do novo Paradigma, que contemple o efetivo recobrimento inicial da área a ser restaurada em curto prazo, e ao mesmo tempo crie condições ambientais para o desenvolvimento das espécies finais de sucessão com alta diversidade, característica principal das matas ciliares e requisito fundamental para a restauração dos processos ecológicos (Barbosa, 2004; Rodrigues \& Gandolfi, 2004, Rodrigues et al., 2004b). A criação desses ambientes favoráveis tem como objetivo a redução dos custos de implantação e ao mesmo tempo aumentar as chances de perpetuação da floresta implantada (Rodrigues \& Gandolfi, 2004). Nesse sentido, as pesquisas envolvendo a forma da copa, exigência de luz para o desenvolvimento, dinâmica das florestas implantadas e genética de populações, são abordagens que podem resultar em combinações ideais de grupos de espécies (Barbosa, 2004) criando novos modelos de restauração (Kageyama \& Gandara, 2004).

A escolha ou criação de um modelo de restauração é um processo em constante aprimoramento, que é alimentado não só pelos conceitos básicos sobre ecologia, demografia, genética, biogeografia, mas também, pelas informações sobre o ambiente físico e biológico da região onde será executado (Kageyama \& Gandara, 2004). 
Dentro dessa contextualização, este trabalho visa testar um modelo metodológico desenvolvido pelo Laboratório de Ecologia e Restauração Florestal - LERF da ESALQ/USP (Rodrigues et al., 2001; Rodrigues et al., 2003a, 2003b, 2003c; Lopes et al., 2004; Fundação Florestal, 2004; Rodrigues et al., 2004b), de recobrimento rápido do terreno com alta diversidade. O método usa linhas de "Preechimento" com espécies de rápido crescimento e boa cobertura e linhas de "Diversidade" com grande número de espécies dos vários grupos ecológicos, sem as características de rápido crescimento e boa cobertura. Neste modelo é usado o máximo de diversidade em cada linha e a adequação dessas espécies com as condições edáficas e climáticas locais.

Assim, esse trabalho tem como objetivo responder as seguintes perguntas: a) Durante o plantio é possível combinar as espécies florestais com alta diversidade em grupos de preenchimento e diversidade de forma que se obtenha um recobrimento eficiente da área em restauração e maior probabilidade de perpetuação da área restaurada? b) A metodologia utilizada para quantificar o recobrimento pode ser usada, de forma prática, nas atividades de monitoramento de áreas restauradas? c) É possível verificar, pela metodologia utilizada, se as classificações de plantio (Preenchimento e Diversidade) das espécies estão corretas? d) Existe a possibilidade de melhoria do modelo de restauração utilizado?

\subsection{Material e Métodos}

\subsection{1 Área estudada}

Este trabalho foi desenvolvido na Companhia de Cimento Ribeirão Grande (CCRG), distante aproximadamente $12,5 \mathrm{~km}$ ao sul do município de Ribeirão Grande, SP e cerca de $250 \mathrm{~km}$ da cidade de São Paulo (Figura 1). A empresa tem como atividade mineraria a exploração de metacalcários e argila para produção de cimento. 


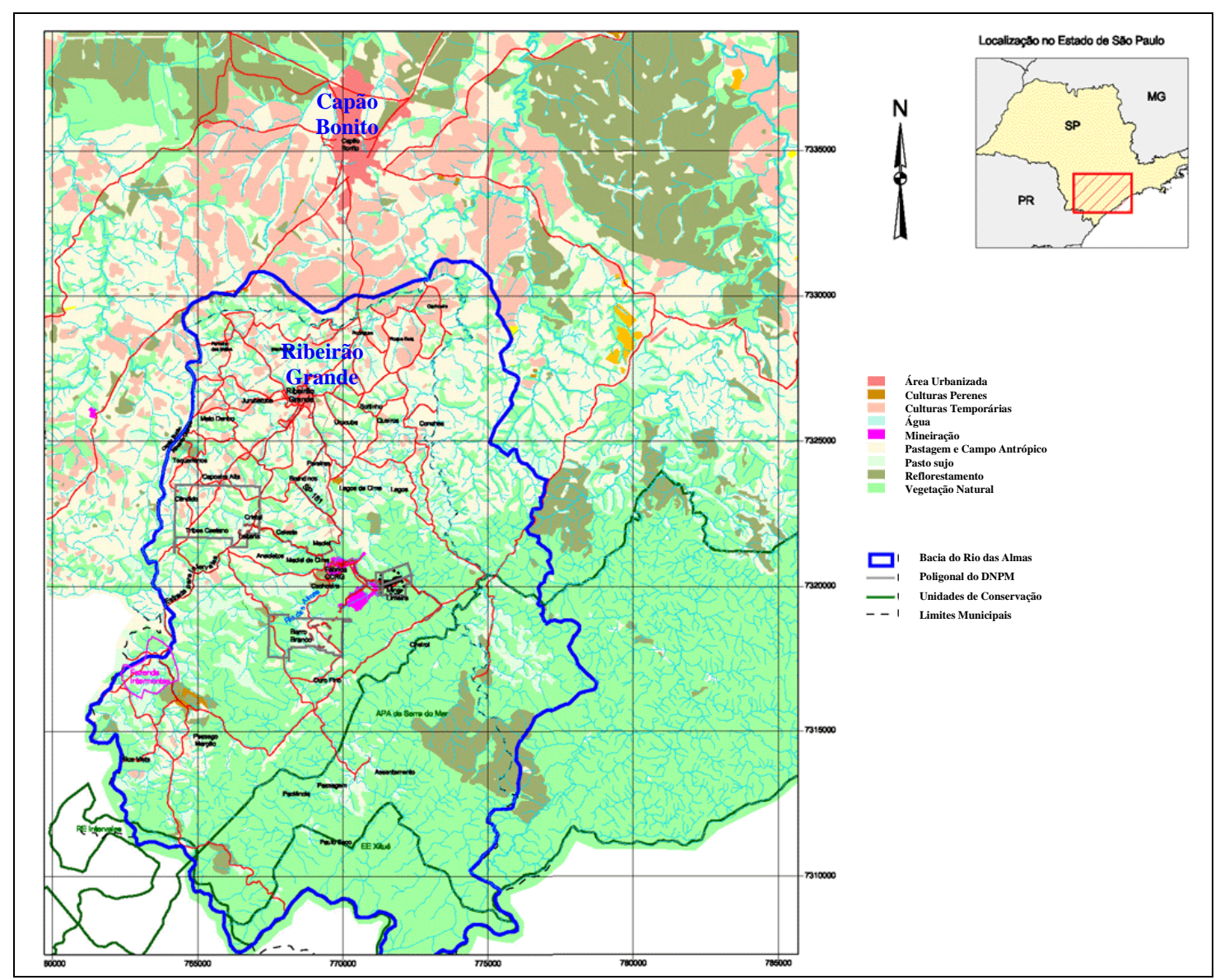

Figura 1 - Localização da região do município de Ribeirão Grande e da Cia de Cimentos Ribeirão Grande no Estado de São Paulo

Com as medidas compensatórias geradas com o corte da vegetação na mina Limeira (autorizada pelo DEPRN em 08/02/2001), a CCRG definiu a restauração da Fazenda Intermontes como local para essas atividades. A Fazenda teve um estudo realizado pelo Laboratório de Ecologia e Restauração Florestal (LERF), definindo as metodologias de restauração nas diferentes situações ambientais da propriedade (Capítulo 3). Entre as metodologias de restauração adotadas, foi implantado um modelo de plantio baseado em conceitos ou funções de "Preenchimento" e de "Diversidade" das espécies, o qual teve seus resultados testados. 
Essa atividade de restauração deu origem a esse trabalho, visando o desenvolvimento de novas metodologias para subsidiar as futuras atividades de restauração florestal.

O trabalho foi realizado na Fazenda Intermontes que possui 343 ha na sua escritura e pertence à Companhia de Cimento Ribeirão Grande (CCRG), localizada na estrada que liga o município de Ribeirão Grande ao Parque Estadual de Intervales, distante aproximadamente $17 \mathrm{~km}$ ao sul do Município de Ribeirão Grande (Figura 2). Sua localização geográfica está inserida entre as coordenadas UTM $7.322 .500 \mathrm{~N}$; 762.750 L e 7.319.800 N; 760.250 L.

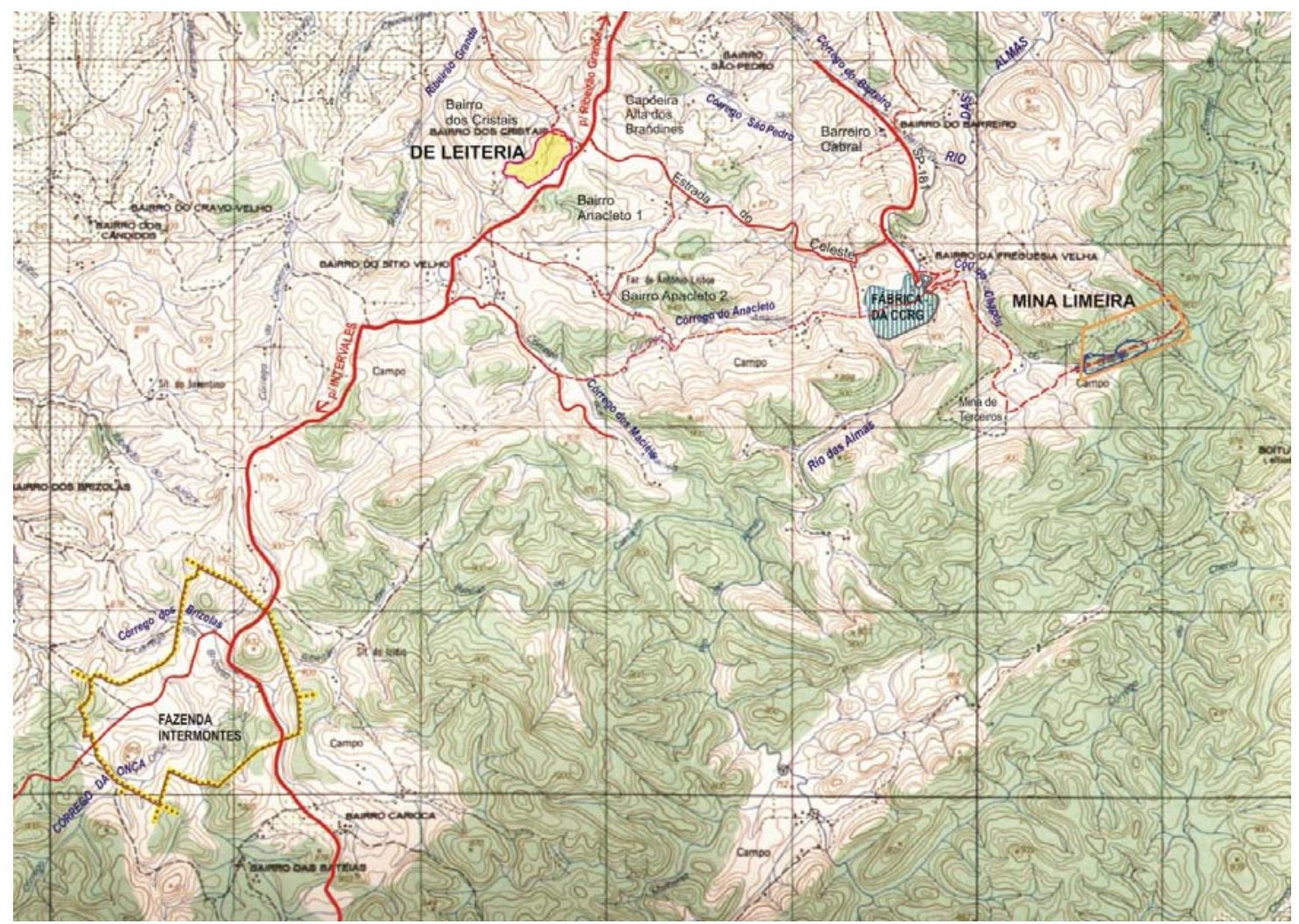

Figura 2 - Croqui de localização com a localização da Fábrica, Mina e da Fazenda Intermontes, pertencentes à CCRG, município de Ribeirão Grande, SP 
A área em estudo está inserida na Província Geomorfológica do Planalto Atlântico, Zona do Planalto de Guapiara, que compreende a região elevada do Alto da Serra de Paranapiacaba e estende-se até a cobertura sedimentar da bacia do Paraná. É uma região que comporta os afluentes de alto curso da margem esquerda do Paranapanema, cuja borda sul marca o divisor de águas da drenagem continental (Vale do Paranapanema) e da litorânea (Vale do Ribeira) (CCRG, 2003).

A declividade dominante está entre 20 a $30 \%$, onde os fundos dos vales estão acima de $800 \mathrm{~m}$ de altitude e os espigões muitas vezes ultrapassam os $1.000 \mathrm{~m}$ de altitude (CCRG, 2003).

Essas características definem para região, segundo a classificação de Köeppen (1948), o clima temperado úmido sem estiagem (Cfb), que ocupa áreas do Planalto de Guapiara com altitudes superiores a $800 \mathrm{~m}$. Nessa parte mais alta da Serra de Paranapiacaba, as temperaturas médias são inferiores a $18^{\circ} \mathrm{C}$ no mês mais frio e inferiores a $22^{\circ} \mathrm{C}$ no mês mais quente (Nimer, 1989; Setzer, 1966).

A precipitação média da bacia do Córrego do Chapéu, situada a cerca de $12 \mathrm{~km}$ da Fazenda Intermontes, é de $1300 \mathrm{~mm}$, variando de 1.100 e $1.500 \mathrm{~mm}$ por ano, com chuvas concentradas no verão, principalmente nos meses de dezembro, janeiro e fevereiro. Nessa região, o período correspondente ao inverno é o que apresenta maior redução dos índices pluviométricos. O total pluviométrico do mês mais seco é superior a $30 \mathrm{~mm}$ (CCRG, 2003). As temperaturas mínimas absolutas anuais chegam a $-4{ }^{\circ} \mathrm{C}$, nas altitudes mais elevadas, ocorrendo em média de um a cinco dias de geada por ano (Nimer, 1989; Setzer, 1966).

\subsubsection{A vegetação regional}

A vegetação do município de Ribeirão Grande localiza-se no Planalto Atlântico do Estado de São Paulo, na divisa com a Província Costeira, próxima a escarpa do Planalto Atlântico, onde predomina a Floresta Estacional Semidecidual, mas devido à 
proximidade com a Serra de Paranapiacaba, apresenta muitas espécies típicas da Floresta Ombrófila Densa na composição florística local (CCRG, 2003).

A flora regional tem contribuições de várias formações, na região do Parque Estadual de Intervales ocorrem as chamadas Florestas Ombrófilas, por desenvolveremse em clima úmido sem período de estiagem (Mantovani, 1994). No reverso da Serra de Paranapiacaba, estende-se até Capão Bonito, o estremo norte do domínio da Floresta de Araucárias, formação dos climas temperados quentes e úmidos ou subtropicais úmidos do Sul do Brasil (Klein, 1984). Nas drenagens do Vale do Paranapanema, originam-se provavelmente as espécies típicas de Floresta Estacional Semidecidual do interior dos Estados de São Paulo, Paraná e Minas Gerais (Mantovani, 1994).

As florestas da região encontram-se em estádios diferenciados de sucessão, resultado de ocupação para prática de agricultura por períodos variáveis e pela extração seletiva de madeira e do palmiteiro (Mantovani, 1994). Geralmente os trechos florestais bem conservados encontram-se nas encostas mais íngremes ou em locais de difícil acesso.

\subsubsection{Coleta de dados}

Neste trabalho, foi testada a eficiência da cobertura das copas de dois grupos de espécies usadas em um modelo metodológico de restauração florestal, utilizado pelo LERF desde 2001 na Fazenda Intermontes. Esta metodologia foi fundamentada num conceito que tem como premissa o rápido recobrimento da área e o uso de alta diversidade.

Dentro deste conceito o LERF criou 2 grupos chamados de "grupos funcionais" ou "grupos de plantio", sendo eles o "grupo de Preenchimento" e "grupo de Diversidade” (Rodrigues et al., 2001; Rodrigues et al., 2003a, 2003b, 2003c; Lopes et al., 2004; Rodrigues et al., 2004b).

O grupo de Preenchimento tem como função o rápido recobrimento $\mathrm{e}$ sombreamento da área, com diversidade e, portanto, heterogeneidade de copa, de 
sombreamento, de uso dos recursos, etc., criando um ambiente favorável ao desenvolvimento dos indivíduos do grupo de Diversidade e, ao mesmo tempo, desfavorecendo a recolonização da área por espécies competidoras como gramíneas, lianas agressivas, etc. Nesse grupo de Preenchimento são geralmente usadas aproximadamente 20 a 30 espécies, que devem possuir as características de rápido crescimento e boa cobertura ou recobrimento do solo. Apesar do grupo de Preenchimento possuir um número de espécies limitado, deve ser usado o máximo de diversidade possível para potencializar a complexidade do ambiente restaurado.

No grupo de Diversidade incluem-se todas as demais espécies a serem plantadas, que não possuem as características do grupo de Preenchimento, devendo apresentar sempre um grande número de espécies (cerca de 80 a 100 espécies). Portanto, esse grupo é constituído de muitas espécies, mas com poucos indivíduos em cada uma delas que é uma característica indispensável para a restauração da dinâmica florestal. Assim, nessa categoria incluem-se em menor proporção as espécies mais iniciais (pioneiras e secundárias iniciais de copa não frondosa) e principalmente as finais da sucessão (secundárias tardias e/ou clímaces), podendo ser de várias formas de vida, que irão aumentar as chances de perpetuação da floresta restaurada.

Os grupos de plantio foram implantados na forma de modelos de linhas alternadas, sendo uma linha de preenchimento e outra de diversidade. As linhas de plantio apresentaram espaçamento de $3 \mathrm{~m}$ entre elas e $2 \mathrm{~m}$ entre plantas na mesma linha (Figura 3).

Cabe ressaltar que, na restauração dessa área específica tratada nesse trabalho, foram plantados alguns poucos indivíduos de algumas poucas espécies frutíferas exóticas ou nativas não regionais, na função de poleiros naturais, visando atrair dispersores e colaborar na restauração da diversidade, em função das características da paisagem regional, com muitos fragmentos e diferentes estados de conservação. 


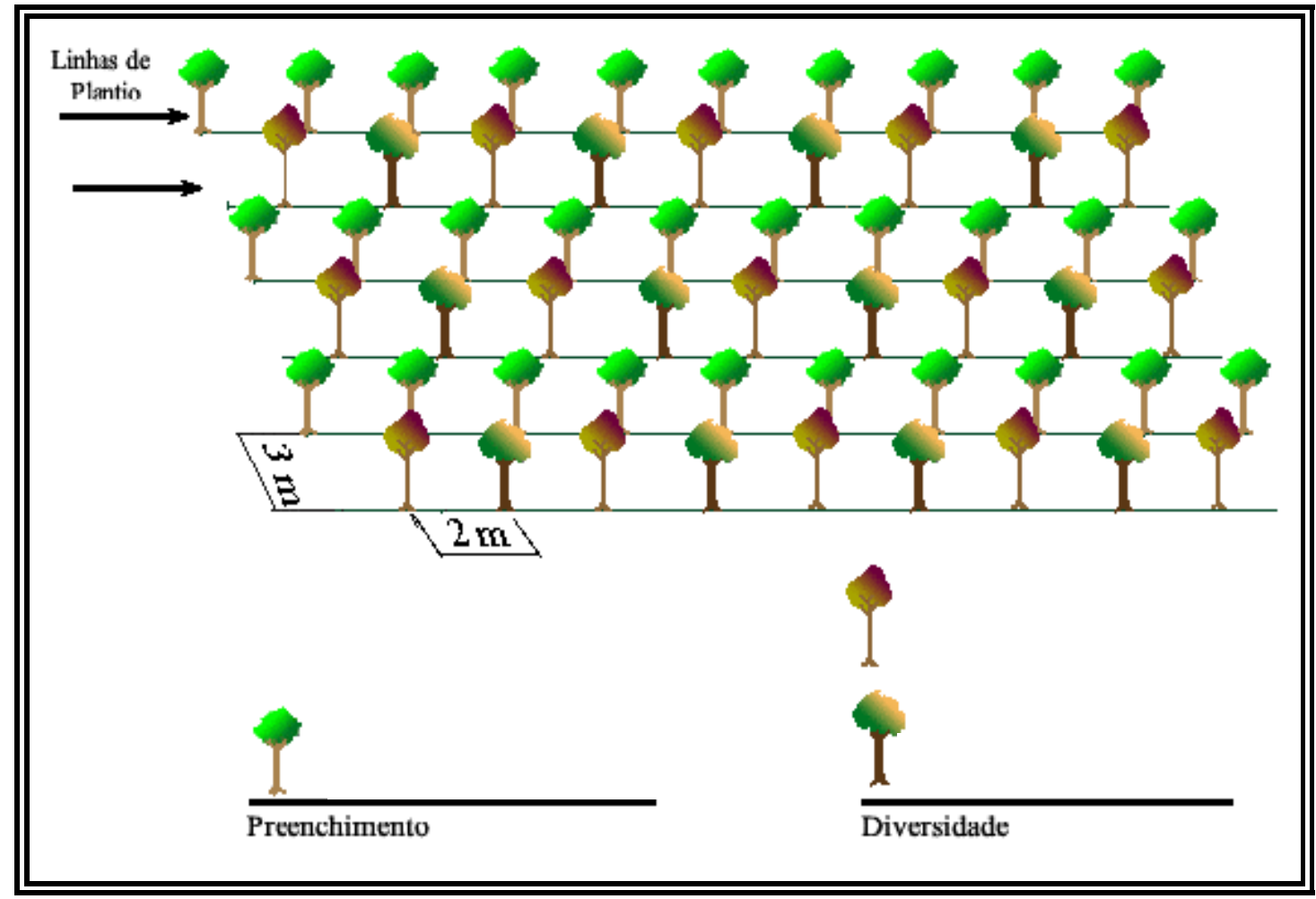

Figura 3 - Desenho esquemático da distribuição dos grupos ecológicos nas linhas de plantio usadas atualmente pelo Laboratório de Ecologia e Restauração Florestal (LERF) da ESALQ/USP, sendo uma linha de preenchimento e uma linha de diversidade

As atividades de manutenção foram realizadas com maior intensidade no primeiro ano pós-plantio, ficando praticamente sem manutenção após esse período, o que não é recomendado na metodologia do LERF, que propõe manutenções periódicas e bem feitas até o recobrimento total da área, girando em torno de 18 a 24 meses. As práticas de manutenção foram realizadas da mesma forma para as linhas de preenchimento e diversidade por meio das seguintes atividades: a) coroamento; b) capina química; c) adubação e; d) controle de formigas.

As medições de cobertura de copa, obtidas pelo diâmetro da largura da copa no sentido da linha de plantio, foram realizadas em 2 comunidades diferentes, sendo uma num reflorestamento com 1,5 anos e outra num reflorestamento com 2,5 anos. $\mathrm{O}$ objetivo foi verificar as diferenças de cobertura entre os grupos de preenchimento e diversidade nas duas comunidades. 
A coleta dos dados foi realizada no mês de julho de 2004, pela medição das copas dos indivíduos plantados de cada espécie com o auxílio de duas trenas de 50 metros, formando transectos de 100 metros cada. As trenas foram colocadas sobre as linhas de plantio, acompanhando as curvas de nível do terreno. As copas foram medidas através da sua projeção vertical sobre a trena (Figuras 4 e 5).

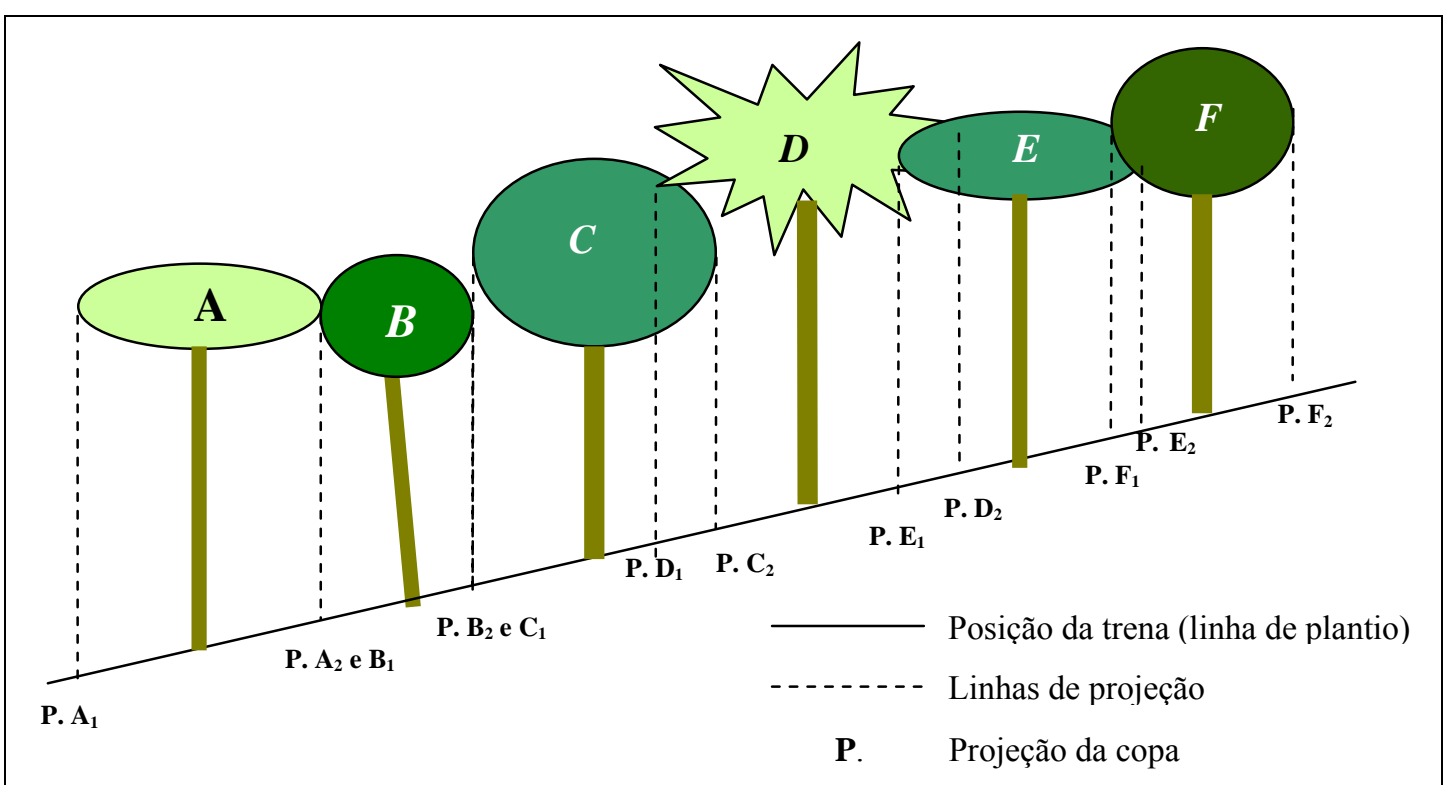

Figura 4 - Esquema utilizado em campo para medição das copas dos indivíduos arbóreos plantados na Fazenda Intermontes, CCRG, SP

A largura das copas foi obtida pela subtração entre as medidas tomadas de cada indivíduo, ou seja, a projeção final da copa sobre a trena - projeção inicial da copa sobre a trena $\left(\mathrm{P}_{2}-\mathrm{P}_{1}\right)$.

As medições foram realizadas em 15 transectos de 100 metros, em cada uma das linhas dos diferentes grupos de plantio. No total, foram amostrados 1500 metros lineares do grupo de Preenchimento e mais 1500 metros lineares para o grupo de Diversidade, somando 3.000 metros lineares para cada idade de plantio amostrada. Portanto, nos dois levantamentos foram amostrados 6.000 metros lineares.

Os pontos iniciais de instalação dos transectos foram distribuídos aleatoriamente pela área do reflorestamento. A aleatoriedade foi obtida por meio de sorteio das 
coordenadas " $\mathrm{X}$ " e "Y", representadas no campo por duas estradas perpendiculares à área de restauração. A Tabela 1 mostra as coordenadas dos pontos de amostragem.

Tabela 1. Coordenadas UTM dos pontos de amostragem das linhas de preenchimento e diversidade do plantio com 1,5 e 2,5 anos

\begin{tabular}{cccccc}
\hline & 1,5 anos & & \multicolumn{2}{c}{2,5 anos } \\
Ponto & $\mathrm{N}(\mathrm{m})$ & $\mathrm{L}(\mathrm{m})$ & Ponto & $\mathrm{N}(\mathrm{m})$ & $\mathrm{L}(\mathrm{m})$ \\
\hline 1 & 0761567 & 7321153 & 1 & 0761028 & 7321242 \\
2 & 0761559 & 7321165 & 2 & 0761112 & 7321135 \\
3 & 0761552 & 7321179 & 3 & 0761049 & 7321230 \\
4 & 0761543 & 7321191 & 4 & 0761447 & 7321783 \\
5 & 0761537 & 7321203 & 5 & 0761094 & 7321233 \\
6 & 0761510 & 7321254 & 6 & 0761473 & 7321887 \\
7 & 0761523 & 7321286 & 7 & 0761094 & 7321146 \\
8 & 0761511 & 7321276 & 8 & 0761062 & 7321166 \\
9 & 0761959 & 7321878 & 9 & 0761129 & 7321161 \\
10 & 0761993 & 7321879 & 10 & 0761157 & 7321103 \\
11 & 0762011 & 7321820 & 11 & 0761348 & 7321453 \\
12 & 0761949 & 7321688 & 12 & 0761462 & 7321838 \\
13 & 0761927 & 7321815 & 13 & 0761093 & 7321197 \\
14 & 0761923 & 7321865 & 14 & 0761529 & 7321661 \\
15 & 0761938 & 7321807 & 15 & 0761048 & 7321268 \\
\hline
\end{tabular}

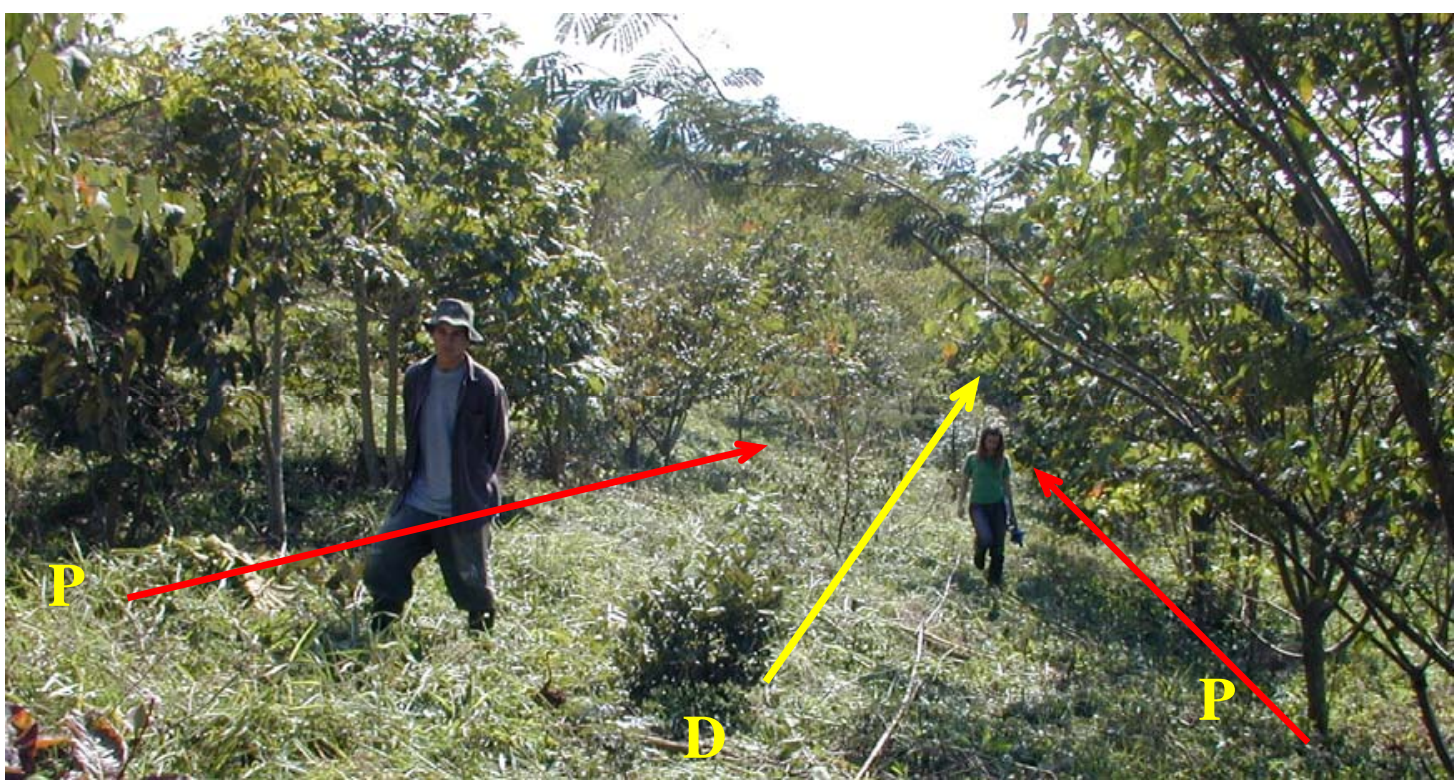

Figura 5 - Um dos transectos onde foi realizado o levantamento, apresentando as "linhas de Preenchimento" (laterais) e "linha de diversidade" (centro), Fazenda Intermontes, CCRG, município de Ribeirão Grande, SP 
Os dados foram analisados apresentando os seguintes resultados: a) porcentagem de cobertura em cada um dos grupos de plantio definida pela somatória da largura das copas em relação ao comprimento total; b) cobertura média da copa dos indivíduos de cada grupo, obtida pela somatória da largura das copas em relação ao número de indivíduos vivos amostrados; c) cobertura média da copa das espécies que apresentaram mais de 10 indivíduos amostrados no plantio com 2,5 anos, obtida pela somatória da largura das copas de uma determinada espécie, dividida pelo número de indivíduos da mesma espécie e; d) mortalidade por grupo de plantio, obtida pelo número de indivíduos mortos em relação ao número de indivíduos amostrados.

Com os dados de cobertura média da copa dos indivíduos de cada grupo, foi possível realizar uma simulação com diferentes modelos de plantio usando diferentes combinações de espaçamento e arranjo entre grupos. Para isso foram utilizados os recursos de desenho do programa Adobe Photoshop 3.0 para ilustração e cálculos de porcentagem de cobertura e sobreposição de copas, usando o recurso de histograma.

Para a colocação das espécies nas suas respectivas famílias botânicas foi usado o sistema de classificação APG II (Angiosperm Phylogeny Group - APG II, 2003), mais aceito atualmente entre a maioria dos pesquisadores da área.

A classe sucessional das espécies amostradas foi definida pelo conceito proposto por Budowski (1965), de pioneiras, secundárias iniciais, secundárias tardias e climácicas, freqüentemente utilizado em trabalhos de restauração.

Durante o trabalho de revisão bibliográfica foram observadas diferenças na classificação sucessional de algumas espécies por diferentes autores. A inexistência de um consenso entre os pesquisadores (Barbosa, 2004; Kageyama \& Gandara, 2004) fez com que fossem consultados vários trabalhos (Gandolfi, 1991, Gandolfi et al., 1995; Gabriel, 1997; Albuquerque, 1999; Fundação Florestal, 2004) e assumida a classificação em que a espécie predominava. 


\subsubsection{Análises estatísticas}

A análise de variância teve como objetivo quantificar o efeito dos fatores Grupos de Plantio (Preenchimento e Diversidade) e Comunidades com diferentes idades (1,5 e 2,5 anos) sobre as variáveis de resposta cobertura média e mortalidade.

As hipóteses levantadas foram: a) A cobertura média dos indivíduos do grupo de Preenchimento dever ser significativamente maior que as espécies do grupo de Diversidade; b) A mortalidade dos indivíduos do grupo de Diversidade deve ser maior que as espécies do grupo de Preenchimento, uma vez que esse se desenvolve melhor a pleno sol.

A análise foi feita com base no Teste de Tukey (Hatcher, 1994), para comparações múltiplas de médias, oriundo de um experimento inteiramente casualizado com dois fatores (Grupo de plantio e Comunidade).

O fator "Grupo de plantio" conta com dois níveis: "Preenchimento" e "Diversidade", ao passo que, o fator “Comunidade" conta com dois níveis: "1,5" e "2,5" anos.

Como todos os níveis dos dois fatores foram combinados gerando um total de 4 (quatro) grupos, tratou-se de um experimento inteiramente casualizado com arranjo fatorial de dois fatores $(2 \times 2)$.

Segundo Hatcher (1994), foram testadas 4 suposições da análise de variância: a) Homogeneidade de variâncias; b) Escala da variável de resposta no mínimo intervalar; c) Distribuição normal; d) Independência das observações e; e) Amostragem aleatória.

A análise de agrupamento foi realizada para agrupar espécies com características de desenvolvimento de copa semelhante e relacioná-las com os grupos de Diversidade ou de Preenchimento. Para isso, foi utilizado o método "Average Linkage" (SAS Institute Inc., 1999) calculando as distâncias médias entre grupos.

Nesse estudo foi utilizada somente a variável Cobertura Média das espécies com pelo menos 10 indivíduos que quantifica o crescimento da largura da copa.

Foi considerado um nível de significância de 5\%. Todas as análises foram realizadas pelo programa estatístico SAS (SAS Institute Inc., 1999). 


\subsection{Resultados e Discussão}

Somando-se os resultados das duas comunidades com diferentes idades de plantio, foram amostrados 2.787 indivíduos pertencentes a 143 espécies e 45 famílias botânicas, sendo 35 espécies pertencentes ao grupo de Preenchimento e 108 espécies pertencentes ao grupo de Diversidade. A Tabela 2 apresenta todas as espécies dos grupos de Preenchimento e Diversidade encontradas neste trabalho, especificando a idade do plantio em que foi encontrada e o grupo de plantio determinado pelo LERF para a implantação do projeto.

Para o reflorestamento com idade de 2,5 anos, foram mensurados 1.283 indivíduos, pertencentes a 114 espécies e 31 famílias botânicas, sendo 627 indivíduos e 34 espécies na linha de preenchimento e 656 indivíduos e 80 espécies na linha de diversidade. Para o reflorestamento com a idade de 1,5 anos foram amostrados 1.504 indivíduos, pertencentes a 109 espécies e 29 famílias botânicas, sendo 736 indivíduos e 28 espécies na linha de preenchimento e 768 indivíduos e 81 espécies na linha de diversidade.

O reflorestamento com 2,5 anos apresentou a média de 24,0 indivíduos do grupo de Preenchimento por hectare e 10,7 indivíduos do grupo de Diversidade por hectare. Esses números se mantiveram próximos dos encontrados para o reflorestamento com 1,5 anos, que apresentou a média de 29,1 indivíduos do grupo de Preenchimento por hectare e 10,5 indivíduos do grupo de Diversidade por hectare. 
Tabela 2. Espécies encontradas nos levantamentos especificando a idade do plantio e o grupo de plantio (G.P.). $\mathrm{P}=$ Preenchimento e $\mathrm{D}=$ diversidade. $\mathrm{N} / \mathrm{E}=$ Nativa ou Exótica. $\mathrm{N}=$ nativa; $\mathrm{E}=$ exótica regional

\begin{tabular}{|c|c|c|c|c|c|c|c|}
\hline \multirow{2}{*}{ Família } & \multirow{2}{*}{ Nome Científico } & \multirow{2}{*}{ Autor } & \multirow{2}{*}{ Nome Popular } & \multirow{2}{*}{$\mathrm{N} / \mathrm{E}$} & \multirow{2}{*}{ G.P. } & \multicolumn{2}{|c|}{ Idade (anos) } \\
\hline & & & & & & 1,5 & 2,5 \\
\hline Anacardiaceae & Astronium graveolens & Jacq. & Guaritá & $\mathrm{N}$ & $\mathrm{D}$ & $X$ & \\
\hline Anacardiaceae & Lithraea molleoides & (Vell.)Engl. & Aroeira brava & $\mathrm{N}$ & $\mathrm{D}$ & $X$ & $\mathrm{X}$ \\
\hline Anacardiaceae & Schinus molle & L. & Aroeira salsa & $\mathrm{E}$ & $\mathrm{P}$ & & $X$ \\
\hline Anacardiaceae & Schinus terebinthifolius & Raddi & Aroeira pimenteira & $\mathrm{N}$ & $\mathrm{P}$ & $\mathrm{X}$ & $\mathrm{X}$ \\
\hline Annonaceae & Rollinia sericea & (R.E.Fr.) R.E.Fr. & Araticum de porca & $\mathrm{N}$ & $\mathrm{D}$ & $X$ & \\
\hline Annonaceae & Rollinia sylvatica & (A. St. Hil.) Martius & Araticum & $\mathrm{N}$ & $\mathrm{D}$ & $\mathrm{X}$ & $X$ \\
\hline Apiaceae & Dendropanax cuneatus & (DC.) Decne. \& Planch. & Maria Mole & $\mathrm{N}$ & $\mathrm{D}$ & $X$ & \\
\hline Apocynaceae & Aspidosperma cylindrocarpon & Mull.Arg & Peroba poca & $\mathrm{N}$ & $\mathrm{D}$ & $\mathrm{X}$ & $\mathrm{X}$ \\
\hline Apocynaceae & Aspidosperma parvifolium & A. DC. & Guatambu-branco & $\mathrm{N}$ & $\mathrm{D}$ & $\mathrm{X}$ & \\
\hline Apocynaceae & Aspidosperma ramiflorum & Müll. Arg. & Guatambu & $\mathrm{N}$ & $\mathrm{D}$ & $\mathrm{X}$ & $\mathrm{X}$ \\
\hline Apocynaceae & Aspidosperma subincanum & Mart. & Guatambu-vermelho & $\mathrm{N}$ & $\mathrm{D}$ & $\mathrm{X}$ & \\
\hline Apocynaceae & $\begin{array}{l}\text { Tabernaemontana } \\
\text { catharinensis }\end{array}$ & A. DC. & Leiteiro & $\mathrm{N}$ & $\mathrm{D}$ & X & $X$ \\
\hline Araucariaceae & Araucaria angustifolia & (Bertol.) Kuntze & Araucária & $\mathrm{N}$ & $\mathrm{D}$ & $\mathrm{X}$ & $\mathrm{X}$ \\
\hline Arecaceae & Syagrus romanzoffiana & (Cham.) Glassman & Jerivá & $\mathrm{N}$ & $\mathrm{D}$ & $\mathrm{X}$ & $\mathrm{X}$ \\
\hline Asteraceae & Baccharis schultzii & Baker & Vassoura & $\mathrm{N}$ & $\mathrm{D}$ & $\mathrm{X}$ & \\
\hline Asteraceae & Gochnatia polymorpha & (Less.)Cabrera & Cambará & $\mathrm{N}$ & $\mathrm{D}$ & $\mathrm{X}$ & $\mathrm{X}$ \\
\hline Bignoniaceae & Jacaranda cuspidifolia & Mart. ex A. DC. & Caroba & $\mathrm{E}$ & $\mathrm{D}$ & & $\mathrm{X}$ \\
\hline Bignoniaceae & Jacaranda mimosifolia & D. Don & Jacarandá mimoso & $\mathrm{E}$ & $\mathrm{D}$ & $\mathrm{X}$ & $X$ \\
\hline Bignoniaceae & Tabebuia impetiginosa & (Mart. ex DC.) Standl. & Ipê roxo & $\mathrm{N}$ & $\mathrm{D}$ & $\mathrm{X}$ & $\mathrm{X}$ \\
\hline Bignoniaceae & Tabebuia chrysotricha & (Mart. ex A. DC.) Standl. & Ipê amarelo & $\mathrm{N}$ & $\mathrm{D}$ & $\mathrm{X}$ & $\mathrm{X}$ \\
\hline Bignoniaceae & Tabebuia heptaphylla & (Vell.) Toledo & Ipê rosa & $\mathrm{N}$ & $\mathrm{D}$ & & $\mathrm{X}$ \\
\hline Bixaceae & Bixa orellana & L. & Urucum & $\mathrm{E}$ & $\mathrm{D}$ & & $\mathrm{X}$ \\
\hline Boraginaceae & Cordia ecalyculata & vell. & Chá de bugre & $\mathrm{N}$ & $\mathrm{D}$ & $\mathrm{X}$ & $X$ \\
\hline Boraginaceae & Cordia myxa & L. & Porangaba & $\mathrm{E}$ & $\mathrm{P}$ & $\mathrm{X}$ & $\mathrm{X}$ \\
\hline Boraginaceae & Cordia trichotoma & (Vell.) Arráb. ex Steud. & Louro pardo & $\mathrm{N}$ & $\mathrm{D}$ & $\mathrm{X}$ & $X$ \\
\hline $\begin{array}{l}\text { Fabaceae } \\
\text { Caesalpinioideae }\end{array}$ & Caesalpinia peltophoroides & Benth. & Sibipiruna & $\mathrm{E}$ & $\mathrm{D}$ & X & X \\
\hline $\begin{array}{l}\text { Fabaceae } \\
\text { Caesalpinioideae }\end{array}$ & Cassia tora & $\mathrm{L}$. & Mata pasto & $\mathrm{E}$ & $\mathrm{D}$ & & $\mathrm{X}$ \\
\hline $\begin{array}{l}\text { Fabaceae } \\
\text { Caesalpinioideae }\end{array}$ & Copaifera langsdorffii & Desf. & Copaíba & $\mathrm{N}$ & $\mathrm{D}$ & $X$ & $X$ \\
\hline $\begin{array}{l}\text { Fabaceae } \\
\text { Caesalpinioideae }\end{array}$ & Copaifera trapezifolia & Hayne & Copaúva & $\mathrm{N}$ & $\mathrm{D}$ & & $X$ \\
\hline $\begin{array}{l}\text { Fabaceae } \\
\text { Caesalpinioideae }\end{array}$ & Hymenaea courbaril & L. & Jatobá & $\mathrm{N}$ & $\mathrm{D}$ & $\mathrm{X}$ & $\mathrm{X}$ \\
\hline $\begin{array}{l}\text { Fabaceae } \\
\text { Caesalpinioideae }\end{array}$ & Peltophorum dubium & Taub. & Canafistula & $\mathrm{N}$ & $\mathrm{P}$ & $\mathrm{X}$ & $X$ \\
\hline $\begin{array}{l}\text { Fabaceae } \\
\text { Caesalpinioideae }\end{array}$ & Schizolobium parahyba & (Vell.) S.F. Blake & Guapuruvu & $\mathrm{N}$ & $\mathrm{D}$ & $X$ & $X$ \\
\hline $\begin{array}{l}\text { Fabaceae } \\
\text { Caesalpinioideae }\end{array}$ & Senna alata & (L.) Roxb. & Fedegoso Gigante & $\mathrm{E}$ & $\mathrm{P}$ & $X$ & $X$ \\
\hline $\begin{array}{l}\text { Fabaceae } \\
\text { Caesalpinioideae }\end{array}$ & Senna macranthera & $\begin{array}{l}\text { (DC. ex Collad.) H.S. Irwin } \\
\text { \& Barneby }\end{array}$ & Fedegoso & $\mathrm{N}$ & $\mathrm{P}$ & $\mathrm{X}$ & $\mathrm{X}$ \\
\hline $\begin{array}{l}\text { Fabaceae } \\
\text { Caesalpinioideae }\end{array}$ & Senna multijuga & $\begin{array}{l}\text { (Rich.) H.S. Irwin \& } \\
\text { Barneby }\end{array}$ & Pau cigarra & $\mathrm{N}$ & $\mathrm{P}$ & $X$ & $\mathrm{X}$ \\
\hline $\begin{array}{l}\text { Fabaceae } \\
\text { Caesalpinioideae }\end{array}$ & Senna pendula & $\begin{array}{l}\text { (Humb. \& Bonpl. ex Willd.) } \\
\text { H.S. Irwin \& Barneby }\end{array}$ & Canudo-de-pito & $\mathrm{N}$ & $\mathrm{D}$ & $X$ & $\mathrm{X}$ \\
\hline $\begin{array}{l}\text { Fabaceae } \\
\text { Caesalpinioideae }\end{array}$ & Pterogyne nitens & Tul. & Amendoim bravo & $\mathrm{N}$ & $\mathrm{P}$ & $\mathrm{X}$ & $\mathrm{X}$ \\
\hline
\end{tabular}


Tabela 2. Espécies encontradas nos levantamentos especificando a idade do plantio e o grupo de plantio (G.P.). $\mathrm{P}=$ Preenchimento e $\mathrm{D}=$ diversidade. $\mathrm{N} / \mathrm{E}=$ Nativa ou Exótica. $\mathrm{N}=$ nativa; $\mathrm{E}=$ exótica regional

\begin{tabular}{|c|c|c|c|c|c|c|c|}
\hline \multirow{2}{*}{ Família } & \multirow{2}{*}{ Nome Científico } & \multirow{2}{*}{ Autor } & \multirow{2}{*}{ Nome Popular } & \multirow{2}{*}{$\mathrm{N} / \mathrm{E}$} & \multirow{2}{*}{ G.P. } & \multicolumn{2}{|c|}{ Idade (anos) } \\
\hline & & & & & & 1,5 & 2,5 \\
\hline Cannabaceae & Trema micrantha & (L.) Blume & Crindiúva & $\mathrm{N}$ & $\mathrm{P}$ & $X$ & \\
\hline Cardiopteridacea & eCitronella paniculata & (Mart.) R.A. Howard & Congonheira & $\mathrm{N}$ & $\mathrm{D}$ & $\mathrm{X}$ & \\
\hline Celastraceae & Maytenus robusta & Reissek & Papagaieiro & $\mathrm{N}$ & $\mathrm{D}$ & $\mathrm{X}$ & \\
\hline Cercideae & Bauhinia forficata & Mart. & Pata de vaca & $\mathrm{N}$ & $\mathrm{P}$ & $X$ & $\mathrm{X}$ \\
\hline Cercideae & Bauhinia purpurea & Wall. & Pata-de-vaca-roxa & $\mathrm{E}$ & $\mathrm{P}$ & $\mathrm{X}$ & $\mathrm{X}$ \\
\hline Combretaceae & Terminalia brasiliensis & $\begin{array}{l}\text { (Cambess. ex A. St.-Hil.) } \\
\text { Eichler }\end{array}$ & Amarelinho & $\mathrm{N}$ & $\mathrm{D}$ & $\mathrm{X}$ & $\mathrm{X}$ \\
\hline Connaraceae & Connarus regnellii & G.Schellenb. & Camboatã-da-serra & $\mathrm{N}$ & $\mathrm{D}$ & & $\mathrm{X}$ \\
\hline Erythroxylaceae & Erytroxyllum $s p$ & & & $\mathrm{~N}$ & $\mathrm{D}$ & $\mathrm{X}$ & \\
\hline Euphorbiaceae & Alchornea triplinervia & (Spreng.) Müll. Arg. & Boleira & $\mathrm{N}$ & $\mathrm{P}$ & $\mathrm{X}$ & $\mathrm{X}$ \\
\hline Euphorbiaceae & Croton lindenianus & A. Rich. & Capixingui da Serra & $\mathrm{N}$ & $\mathrm{P}$ & & $\mathrm{X}$ \\
\hline Euphorbiaceae & Croton urucurana & Baill. & Sangra d’água & $\mathrm{N}$ & $\mathrm{P}$ & $\mathrm{X}$ & $\mathrm{X}$ \\
\hline Euphorbiaceae & Joannesia princeps & vell. & Boleira & $\mathrm{E}$ & $\mathrm{D}$ & & $\mathrm{X}$ \\
\hline Euphorbiaceae & Sapium glandulatum & (Vell.) Pax & Leiteiro & $\mathrm{N}$ & $\mathrm{D}$ & & $\mathrm{X}$ \\
\hline Euphorbiaceae & Sebastiania serrata & (Baill.exMüll.Arg.)Müll.Arg & Branquilho & $\mathrm{N}$ & $\mathrm{D}$ & $\mathrm{X}$ & $\mathrm{X}$ \\
\hline Euphorbiaceae & Croton floribundus & Spreng. & Capixingui & $\mathrm{N}$ & $\mathrm{P}$ & $\mathrm{X}$ & $\mathrm{X}$ \\
\hline Euphorbiaceae & Actinostemon concolor & (Spreng.) Müll. Arg. & & $\mathrm{N}$ & $\mathrm{D}$ & $\mathrm{X}$ & \\
\hline $\begin{array}{l}\text { Fabaceae } \\
\text { Faboideae }\end{array}$ & Centrolobium tomentosum & Guillemin ex Benth. & Araribá & $\mathrm{N}$ & $\mathrm{D}$ & $\mathrm{X}$ & $\mathrm{X}$ \\
\hline $\begin{array}{l}\text { Fabaceae } \\
\text { Faboideae }\end{array}$ & Dalbergia frutescens & (Vell.) Britton & Jacarandá Rosa & $\mathrm{N}$ & $\mathrm{D}$ & $\mathrm{X}$ & \\
\hline $\begin{array}{l}\text { Fabaceae } \\
\text { Faboideae }\end{array}$ & Dipteryx alata & Vogel & Baru & $\mathrm{E}$ & $\mathrm{D}$ & $X$ & \\
\hline $\begin{array}{l}\text { Fabaceae } \\
\text { Faboideae }\end{array}$ & Erythrina speciosa & Andrews & Mulungu-do-litoral & $\mathrm{E}$ & $\mathrm{D}$ & $\mathrm{X}$ & $\mathrm{X}$ \\
\hline $\begin{array}{l}\text { Fabaceae } \\
\text { Faboideae }\end{array}$ & Lonchocarpus campestris & Mart. Ex Benth. & Sapuva & $\mathrm{N}$ & $\mathrm{D}$ & $\mathrm{X}$ & $\mathrm{X}$ \\
\hline $\begin{array}{l}\text { Fabaceae } \\
\text { Faboideae }\end{array}$ & $\begin{array}{l}\text { Lonchocarpus } \\
\text { muehlbergianus }\end{array}$ & Hassl. & Embira de sapo & $\mathrm{N}$ & $\mathrm{D}$ & $\mathrm{X}$ & $\mathrm{X}$ \\
\hline $\begin{array}{l}\text { Fabaceae } \\
\text { Faboideae }\end{array}$ & Machaerium hirtum & Stellfeld & Bico de pato & $\mathrm{N}$ & $\mathrm{P}$ & & $\mathrm{X}$ \\
\hline $\begin{array}{l}\text { Fabaceae } \\
\text { Faboideae }\end{array}$ & Machaerium nyctitans & (Vell.)Benth. & Bico de pato & $\mathrm{N}$ & $\mathrm{D}$ & $\mathrm{X}$ & $\mathrm{X}$ \\
\hline $\begin{array}{l}\text { Fabaceae } \\
\text { Faboideae }\end{array}$ & Machaerium paraguariense & Hassl. & jacarandá & $\mathrm{N}$ & $\mathrm{D}$ & $\mathrm{X}$ & $\mathrm{X}$ \\
\hline $\begin{array}{l}\text { Fabaceae } \\
\text { Faboideae }\end{array}$ & Machaerium stiptatum & Pers. & Sapuvinha & $\mathrm{N}$ & $\mathrm{D}$ & $\mathrm{X}$ & \\
\hline $\begin{array}{l}\text { Fabaceae } \\
\text { Faboideae }\end{array}$ & Myroxylon peruiferum & L.f. & Cabreúva & $\mathrm{N}$ & $\mathrm{D}$ & & $\mathrm{X}$ \\
\hline $\begin{array}{l}\text { Fabaceae } \\
\text { Faboideae }\end{array}$ & Platypodium elegans & Vogel & Jacarandá do campo & $\mathrm{E}$ & $\mathrm{D}$ & & $\mathrm{X}$ \\
\hline $\begin{array}{l}\text { Fabaceae } \\
\text { Faboideae }\end{array}$ & Poecilanthe parviflora & Benth. & Coração de negro & $\mathrm{N}$ & $\mathrm{D}$ & $\mathrm{X}$ & $\mathrm{X}$ \\
\hline $\begin{array}{l}\text { Fabaceae } \\
\text { Faboideae }\end{array}$ & Pterocarpus violaceus & Vogel & Aldrago & $\mathrm{N}$ & $\mathrm{D}$ & $X$ & $\mathrm{X}$ \\
\hline $\begin{array}{l}\text { Fabaceae } \\
\text { Faboideae }\end{array}$ & Sesbania sesban & Fawc. \& Rendle & Alelueiro & $\mathrm{E}$ & $\mathrm{P}$ & $\mathrm{X}$ & $\mathrm{X}$ \\
\hline Lamiaceae & Aegiphila sellowiana & Cham. & Tamanqueira & $\mathrm{N}$ & $\mathrm{P}$ & $\mathrm{X}$ & $\mathrm{X}$ \\
\hline Lamiaceae & Vitex montevidensis & Cham. & Tarumã & $\mathrm{N}$ & $\mathrm{D}$ & & $\mathrm{X}$ \\
\hline Lauraceae & Ocotea dispersa & (Nees) Mez & Canelão & $\mathrm{N}$ & $\mathrm{D}$ & $\mathrm{X}$ & \\
\hline Lauraceae & Cryptocarya aschersoniana & Mez. & Canela- batalha & $\mathrm{N}$ & $\mathrm{D}$ & $\mathrm{X}$ & $\mathrm{X}$ \\
\hline Lauraceae & Nectandra leucantha & Nees \& Mart & & $\mathrm{N}$ & $\mathrm{D}$ & & $\mathrm{X}$ \\
\hline
\end{tabular}


Tabela 2. Espécies encontradas nos levantamentos especificando a idade do plantio e o grupo de plantio (G.P.). $\mathrm{P}=$ Preenchimento e $\mathrm{D}=$ diversidade. $\mathrm{N} / \mathrm{E}=$ Nativa ou Exótica. $\mathrm{N}=$ nativa; $\mathrm{E}=$ exótica regional

\begin{tabular}{|c|c|c|c|c|c|c|c|}
\hline \multirow{2}{*}{ Família } & \multirow{2}{*}{ Nome Científico } & \multirow{2}{*}{ Autor } & \multirow{2}{*}{ Nome Popular } & \multirow{2}{*}{$\mathrm{N} / \mathrm{E}$} & \multirow{2}{*}{ G.P. } & \multicolumn{2}{|c|}{ Idade (anos) } \\
\hline & & & & & & 1,5 & 2,5 \\
\hline Lauraceae & Nectandra megapotamica & (Spreng.) Mez & Canelinha & $\mathrm{N}$ & $\mathrm{D}$ & & $\mathrm{X}$ \\
\hline Lauraceae & Ocotea corymbosa & (Meisn.) Mez & Canela & $\mathrm{N}$ & $\mathrm{D}$ & $\mathrm{X}$ & \\
\hline Lecythindaceae & Cariniana estrellensis & (Randdi) Kuntze & Jequitibá branco & $\mathrm{N}$ & $\mathrm{D}$ & $\mathrm{X}$ & \\
\hline Loganiaceae & Strychnos brasiliensis & (Spreng.) Mart. & Salta martim & $\mathrm{N}$ & $\mathrm{D}$ & $\mathrm{X}$ & $\mathrm{X}$ \\
\hline Lythraceae & Lafoensia glyptocarpa & Koehne & Mirindiba rosa & $\mathrm{E}$ & $\mathrm{D}$ & $\mathrm{X}$ & $X$ \\
\hline Lythraceae & Lafoensia pacari & A.St.-Hil. & Dedaleiro & $\mathrm{N}$ & $\mathrm{D}$ & $\mathrm{X}$ & \\
\hline Magnoliaceae & Talauma obovata & Korth. & Pinha do Brejo & $\mathrm{N}$ & $\mathrm{D}$ & $\mathrm{X}$ & \\
\hline Malvaceae & Pachira aquatica & Aubl. & Monguba & $\mathrm{E}$ & $\mathrm{D}$ & & $\mathrm{X}$ \\
\hline Malvaceae & Bombacopsis glabra & (Pasquale) Robyns & $\begin{array}{l}\text { Castanha do } \\
\text { Maranhão }\end{array}$ & $\mathrm{E}$ & $\mathrm{D}$ & $\mathrm{X}$ & \\
\hline Malvaceae & Chorisia speciosa & A. St.-Hil. & Paineira & $\mathrm{N}$ & $\mathrm{D}$ & $\mathrm{X}$ & $\mathrm{X}$ \\
\hline Malvaceae & Guazuma ulmifolia & Lam. & Mutambo & $\mathrm{N}$ & $P$ & $\mathrm{X}$ & $\mathrm{X}$ \\
\hline Malvaceae & Heliocarpus americanus & L. & Pau jangada & $\mathrm{N}$ & $\mathrm{P}$ & $\mathrm{X}$ & $\mathrm{X}$ \\
\hline Malvaceae & Luehea divaricata & Mart. & Açoita cavalo & $\mathrm{N}$ & $\mathrm{P}$ & $\mathrm{X}$ & $\mathrm{X}$ \\
\hline Malvaceae & Luehea grandiflora & Mart. & Açoita cavalo & $\mathrm{N}$ & $\mathrm{P}$ & $\mathrm{X}$ & $\mathrm{X}$ \\
\hline Meliaceae & Cedrela fissilis & Vell. & Cedro & $\mathrm{N}$ & $\mathrm{D}$ & $\mathrm{X}$ & $\mathrm{X}$ \\
\hline $\begin{array}{l}\text { Fabaceae } \\
\text { Mimosoideae }\end{array}$ & Acacia polyphylla & DC. & Monjoleiro & $\mathrm{N}$ & $\mathrm{P}$ & $\mathrm{X}$ & $\mathrm{X}$ \\
\hline $\begin{array}{l}\text { Fabaceae } \\
\text { Mimosoideae }\end{array}$ & Albizia hassleri & (Chodat) Bur Kart. & Farinha seca & $\mathrm{E}$ & $\mathrm{D}$ & $\mathrm{X}$ & X \\
\hline $\begin{array}{l}\text { Fabaceae } \\
\text { Mimosoideae }\end{array}$ & Albizia lebbeck & Benth. & Lingua de sogra & $\mathrm{E}$ & $\mathrm{D}$ & $X$ & $\mathrm{X}$ \\
\hline $\begin{array}{l}\text { Fabaceae } \\
\text { Mimosoideae }\end{array}$ & Anadenanthera falcata & (Benth.) Speg. & Angico cascudo & $\mathrm{E}$ & $\mathrm{P}$ & & $\mathrm{X}$ \\
\hline $\begin{array}{l}\text { Fabaceae } \\
\text { Mimosoideae }\end{array}$ & Anadenanthera macrocarpa & Benth. & Angico vermelho & $\mathrm{N}$ & $\mathrm{P}$ & $\mathrm{X}$ & X \\
\hline $\begin{array}{l}\text { Fabaceae } \\
\text { Mimosoideae }\end{array}$ & Enterolobium contortisiliquum & (Vell). Morong & Orelha de negro & $\mathrm{N}$ & $\mathrm{P}$ & $\mathrm{X}$ & $\mathrm{X}$ \\
\hline $\begin{array}{l}\text { Fabaceae } \\
\text { Mimosoideae }\end{array}$ & Inga marginata & Willd. & Ingá & $\mathrm{N}$ & $\mathrm{D}$ & $\mathrm{X}$ & $X$ \\
\hline $\begin{array}{l}\text { Fabaceae } \\
\text { Mimosoideae }\end{array}$ & Inga sessilis & (Vell).Mart & Ingá ferradura & $\mathrm{N}$ & $\mathrm{P}$ & X & X \\
\hline $\begin{array}{l}\text { Fabaceae } \\
\text { Mimosoideae }\end{array}$ & Inga vera & Willd. & Ingá & $\mathrm{N}$ & $\mathrm{P}$ & & X \\
\hline $\begin{array}{l}\text { Fabaceae } \\
\text { Mimosoideae }\end{array}$ & Leucochloron incuriale & $\begin{array}{l}\text { (Vell.) Barneby \& J.W. } \\
\text { Grimes }\end{array}$ & Angico cascuso & $\mathrm{N}$ & $\mathrm{D}$ & $\mathrm{X}$ & \\
\hline $\begin{array}{l}\text { Fabaceae } \\
\text { Mimosoideae }\end{array}$ & Mimosa bimucronata & (DC.) Kuntze & Maricá & $\mathrm{E}$ & $\mathrm{P}$ & X & $\mathrm{X}$ \\
\hline $\begin{array}{l}\text { Fabaceae } \\
\text { Mimosoideae }\end{array}$ & Mimosa scabrella & Benth. & Bracatinga & $\mathrm{N}$ & $\mathrm{P}$ & & $\mathrm{X}$ \\
\hline $\begin{array}{l}\text { Fabaceae } \\
\text { Mimosoideae }\end{array}$ & Parapiptadenia rigida & (Benth.) Brenan & Guarucaia & $\mathrm{N}$ & $\mathrm{D}$ & $\mathrm{X}$ & $X$ \\
\hline $\begin{array}{l}\text { Fabaceae } \\
\text { Mimosoideae }\end{array}$ & Piptadenia gonoacantha & (Mart.) J.F. Macbr. & Pau jacaré & $\mathrm{N}$ & $\mathrm{P}$ & $\mathrm{X}$ & $\mathrm{X}$ \\
\hline $\begin{array}{l}\text { Fabaceae } \\
\text { Mimosoideae }\end{array}$ & Piptadenia paniculata & Benth. & Arranha-gato & $\mathrm{N}$ & $\mathrm{D}$ & $X$ & $\mathrm{X}$ \\
\hline Myrsinaceae & Rapanea ferruginea & (Ruiz \& Pav.) Mez & Capororoca ferrugem & $\mathrm{N}$ & $\mathrm{D}$ & $\mathrm{X}$ & $\mathrm{X}$ \\
\hline Myrtaceae & Campomanesia neriflora & (O. Berg) Nied. & Gabiroba & $\mathrm{N}$ & $\mathrm{D}$ & $\mathrm{X}$ & $\mathrm{X}$ \\
\hline Myrtaceae & Eugenia cerasiflora & Miq. & & $\mathrm{N}$ & $\mathrm{D}$ & $\mathrm{X}$ & $\mathrm{X}$ \\
\hline Myrtaceae & Eugenia cf bocainensis & Mattos & & $\mathrm{N}$ & $\mathrm{D}$ & & $\mathrm{X}$ \\
\hline Myrtaceae & Eugenia florida & D.C. & Cambuí & $\mathrm{N}$ & $\mathrm{D}$ & & $\mathrm{X}$ \\
\hline Myrtaceae & Eugenia involucrata & DC. & Cereja-do-rio-grande & $\mathrm{E}$ & $\mathrm{D}$ & & $\mathrm{X}$ \\
\hline
\end{tabular}


Tabela 2. Espécies encontradas nos levantamentos especificando a idade do plantio e o grupo de plantio (G.P.). $\mathrm{P}=$ Preenchimento e $\mathrm{D}=$ diversidade. $\mathrm{N} / \mathrm{E}=$ Nativa ou Exótica. $\mathrm{N}=$ nativa; $\mathrm{E}=$ exótica regional

\begin{tabular}{|c|c|c|c|c|c|c|c|}
\hline \multirow{2}{*}{ Família } & \multirow{2}{*}{ Nome Científico } & \multirow{2}{*}{ Autor } & \multirow{2}{*}{ Nome Popular } & \multirow{2}{*}{$\mathrm{N} / \mathrm{E}$} & \multirow{2}{*}{ G.P. } & \multicolumn{2}{|c|}{ Idade (anos) } \\
\hline & & & & & & 1,5 & 2,5 \\
\hline Myrtaceae & Eugenia jambolana & Lam. & Jambolão & $\mathrm{E}$ & $\mathrm{D}$ & $\mathrm{X}$ & \\
\hline Myrtaceae & Eugenia platysema & O. Berg & Cambuí & $\mathrm{N}$ & $\mathrm{D}$ & $\mathrm{X}$ & $\mathrm{X}$ \\
\hline Myrtaceae & Eugenia pluriflora & D.C. & Cambuí & $\mathrm{N}$ & $\mathrm{D}$ & & $\mathrm{X}$ \\
\hline Myrtaceae & Eugenia pruinosa & D. Legrand. & Murta nativa & $\mathrm{N}$ & $\mathrm{D}$ & $\mathrm{X}$ & $\mathrm{X}$ \\
\hline Myrtaceae & Eugenia sp 1 & & & $\mathrm{~N}$ & $\mathrm{D}$ & $\mathrm{X}$ & \\
\hline Myrtaceae & Eugenia uniflora & L. & Pitanga & $\mathrm{E}$ & $\mathrm{D}$ & $\mathrm{X}$ & $\mathrm{X}$ \\
\hline Myrtaceae & Hexachlamys edulis & $\begin{array}{l}\text { (O. Berg) Kausel \& D. } \\
\text { Legrand }\end{array}$ & Pessegueiro do Mato & $\mathrm{N}$ & $\mathrm{D}$ & $\mathrm{X}$ & $\mathrm{X}$ \\
\hline Myrtaceae & Psidium cattleianum & Sabine & Araçá & $\mathrm{N}$ & $\mathrm{D}$ & $\mathrm{X}$ & $\mathrm{X}$ \\
\hline Myrtaceae & Psidium guajava & $\mathrm{L}$. & Goiabeira & $\mathrm{N}$ & $\mathrm{D}$ & $\mathrm{X}$ & $\mathrm{X}$ \\
\hline Nyctaginaceae & Guapira opposita & (Vell.)Reitz & Maria-mole & $\mathrm{N}$ & $\mathrm{D}$ & & $\mathrm{X}$ \\
\hline Phytolaccaceae & Gallesia integrifolia & (Spreng.)Harms & Pau d`alho & $\mathrm{E}$ & $\mathrm{D}$ & $\mathrm{X}$ & \\
\hline Phytolaccaceae & Seguieria langsdorffii & Moq. & Limoeiro bravo & $\mathrm{N}$ & $\mathrm{D}$ & $\mathrm{X}$ & $\mathrm{X}$ \\
\hline Picramniaceae & Picramnia cf parvifolia & Engl. & & $\mathrm{N}$ & $\mathrm{D}$ & $\mathrm{X}$ & \\
\hline Piperaceae & Piper aduncum & $\mathrm{L}$. & & $\mathrm{N}$ & $\mathrm{D}$ & $\mathrm{X}$ & \\
\hline Polygonaceae & Triplaris brasiliana & Cham. & Pau formiga & $\mathrm{E}$ & $\mathrm{D}$ & $\mathrm{X}$ & $\mathrm{X}$ \\
\hline Rhamnaceae & Colubrina glandulosa & Perkins & Saguaragi Vermelho & $\mathrm{N}$ & $\mathrm{D}$ & $\mathrm{X}$ & \\
\hline Rosaceae & Eriobotrya japonica & (Thunb.) Lindl. & Ameixeira & $\mathrm{E}$ & $\mathrm{D}$ & $\mathrm{X}$ & $\mathrm{X}$ \\
\hline Rosaceae & Prunus myrtifolia & (L.) Urb. & Pessegueiro bravo & $\mathrm{N}$ & $\mathrm{P}$ & $\mathrm{X}$ & $X$ \\
\hline Rubiaceae & Coutarea hexandra & (Jacq.) K. Schum. & & $\mathrm{N}$ & $\mathrm{D}$ & $\mathrm{X}$ & $\mathrm{X}$ \\
\hline Rubiaceae & Randia armata & (Sw.) DC. & Espinho de judeu & $\mathrm{N}$ & $\mathrm{D}$ & & $\mathrm{X}$ \\
\hline Rutaceae & Esenbeckia febrifuga & $\begin{array}{l}\text { (A. St. Hil.) A. Juss. ex } \\
\text { Mart. }\end{array}$ & Mamoninha & $\mathrm{N}$ & $\mathrm{D}$ & & $\mathrm{X}$ \\
\hline Rutaceae & Zanthoxylum chiloperone & Mart. ex Engl. & Mamica de Porca & $\mathrm{N}$ & $\mathrm{D}$ & & $\mathrm{X}$ \\
\hline Rutaceae & Zanthoxylum hyemale & A.St-Hil & Mamica de Porca & $\mathrm{N}$ & $\mathrm{D}$ & & $\mathrm{X}$ \\
\hline Rutaceae & Zanthoxylum riedelianum & Engl. & Mamica de Porca & $\mathrm{N}$ & $\mathrm{D}$ & $\mathrm{X}$ & $\mathrm{X}$ \\
\hline Sapindaceae & Cupania vernalis & Camb. & Arco-de-peneira & $\mathrm{N}$ & $\mathrm{D}$ & & $\mathrm{X}$ \\
\hline Sapindaceae & Dilodendron bipinnatum & Radlk. & Maria-podre & $\mathrm{N}$ & $\mathrm{D}$ & & $\mathrm{X}$ \\
\hline Sapindaceae & Matayba elaeagnoides & Radlk. & Camboatá & $\mathrm{N}$ & $\mathrm{D}$ & $\mathrm{X}$ & \\
\hline Sapotaceae & Chrysophyllum marginatum & (Hook. \& Arn.) Radlk. & Leiteiro vermelho & $\mathrm{N}$ & $\mathrm{D}$ & $\mathrm{X}$ & $\mathrm{X}$ \\
\hline Solanaceae & Acnistus arborescens & (L.) Schltdl & Fumo bravo & $\mathrm{N}$ & $\mathrm{P}$ & $\mathrm{X}$ & $\mathrm{X}$ \\
\hline Solanaceae & Solanum concinnum & Sendtn. & & $\mathrm{N}$ & $\mathrm{D}$ & $\mathrm{X}$ & \\
\hline Solanaceae & Solanum granuloso-leprosum & Dunal & Gravitinga & $\mathrm{N}$ & $\mathrm{P}$ & $\mathrm{X}$ & $\mathrm{X}$ \\
\hline Urticaceae & Cecropia pachystachya & Trécul & Embaúba-branca & $\mathrm{N}$ & $\mathrm{D}$ & & $\mathrm{X}$ \\
\hline Verbenaceae & Aloysia virgata & (Ruiz \& Pav.) Juss. & Lixeira & $\mathrm{N}$ & $\mathrm{P}$ & & $\mathrm{X}$ \\
\hline Verbenaceae & Citharexylum myrianthum & Cham. & Pau viola & $\mathrm{N}$ & $\mathrm{D}$ & & $X$ \\
\hline
\end{tabular}

Do ponto de vista da diversidade, chama atenção o número de espécies amostradas, uma vez que o valor obtido é aproximadamente $80 \%$ maior que o exigido pela legislação (Resolução SMA 47, de 21 de setembro de 2003) que é de 80 espécies. O valor também corresponde a 5 vezes a média obtida para a maioria dos reflorestamentos estudados pela CINP no Estado (Barbosa, 2002) que é de 30 espécies. Cabe ressaltar que 
o número de espécies encontradas foi obtido por meio de amostragem, devendo ser ainda maior o número total de espécies plantadas. Esses dados mostraram que é possível a implantação do projeto de restauração com alta diversidade de espécies.

Os resultados de porcentagem de mortalidade, espaçamento médio entre plantas, porcentagem de cobertura nos dois grupos de plantio e a diferença entre as porcentagens de cobertura para a idade de 2,5 e 1,5 anos, são apresentados na Tabela 3.

Tabela 3. Idade do plantio, porcentagem de mortalidade, espaçamento médio entre plantas, porcentagem de cobertura nos dois grupos de plantio, diferença entre as porcentagens de cobertura e cobertura média por indivíduo para as idades de 2,5 e 1,5 anos. Mort. = mortalidade

\begin{tabular}{|c|c|c|c|c|c|c|c|}
\hline $\begin{array}{l}\text { Grupo de } \\
\text { plantio }\end{array}$ & $\begin{array}{c}\text { Idade do } \\
\text { plantio } \\
\text { (anos) }\end{array}$ & $\begin{array}{l}N^{\circ} \text {. de } \\
\text { ind. } \\
\text { amost. }\end{array}$ & $\begin{array}{c}\text { Mort. } \\
\%\end{array}$ & $\begin{array}{l}\text { Espaçamento } \\
\text { Médio (m) }\end{array}$ & $\begin{array}{c}\text { Cobertura* } \\
\%\end{array}$ & $\begin{array}{l}\text { Diferença de } \\
\text { cobertura } \\
\text { entre os } \\
\text { grupos \% }\end{array}$ & $\begin{array}{c}\text { Cobertura } \\
\text { média ** } \\
(\mathbf{m})\end{array}$ \\
\hline Diversidade & 1,5 & 768 & 18,9 & $2,0 \times 3,0$ & 47,0 & \multirow{2}{*}{73,6} & 1,13 \\
\hline Preenchimento & 1,5 & 736 & 14,3 & $2,0 \times 3,0$ & 81,6 & & 1,94 \\
\hline Diversidade & 2,5 & 656 & 13,5 & $2,3 \times 3,0$ & 59,6 & \multirow{2}{*}{83,3} & 1,56 \\
\hline Preenchimento & 2,5 & 627 & 6,7 & $2,4 \times 3,0$ & 109,2 & & 2,80 \\
\hline
\end{tabular}

As Figuras 6 e 7 apresentam as médias e intervalos de confiança para a cobertura média entre os grupos de plantio e a mortalidade entre os grupos de plantio.

Os resultados mostraram que o grupo de Preenchimento apresentou uma porcentagem de cobertura média significativamente maior que a cobertura média do grupo de Diversidade, cumprindo sua principal função no processo de restauração. Isso ocorreu tanto para o reflorestamento com 1,5 anos, como para o reflorestamento com 2,5 anos, sendo que para 1,5 anos a diferença de cobertura foi de $73,6 \%$ maior para o grupo de Preenchimento em relação ao grupo de Diversidade e para 2,5 anos essa diferença foi de $83,3 \%$.

Esses valores mostraram que a função de recobrimento inicial da área restaurada do grupo de Preenchimento foi alcançada já no reflorestamento com 1,5 anos e potencializado com o reflorestamento com 2,5 anos de idade. Esse recobrimento inicial poderá contribuir para diminuição das interferências causadas pelas espécies invasoras 
(mato competição) e criação de ambientes favoráveis à regeneração da vegetação nativa, devido às melhorias na fertilidade, temperatura e umidade do solo e ainda a atração da fauna dispersora de sementes pelo surgimento de novos habitats e recursos alimentícios (Parrota, 1995, Parrota et al., 1997, Tucker \& Murphy 1997, Wunderle Jr., 1997, Souza \& Batista, 2004).

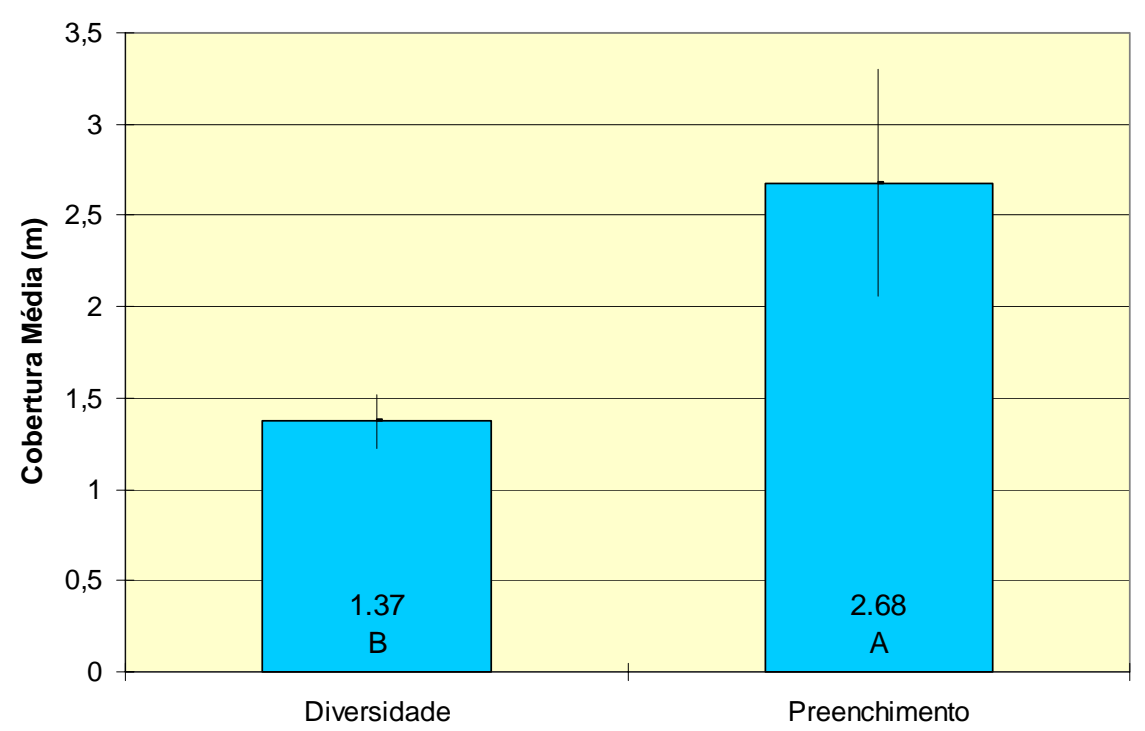

Figura 6 - Cobertura média dos indivíduos dos grupos de Preenchimento e Diversidade (Médias e intervalos de confiança da variável Cobertura Média). Barras com a mesma letra não diferem entre si através do Teste de Tukey ou da análise de variância com nível de significânciade $5 \%$

Os resultados mostraram também que, apesar da alta mortalidade de indivíduos do grupo da diversidade para as duas idades de plantio (Figura 7), o número de espécies amostradas superou o mínimo exigido pela legislação que é de 80 espécies e que foi definido com a participação de especialistas na área de restauração ecológica. $O$ estabelecimento de um número elevado de espécies revela que a função do grupo da diversidade vem sendo mantida, aumentando as chances de restauração dos processos ecológicos e a perpetuação do ambiente restaurado (Rodrigues \& Gandolfi, 2004). 


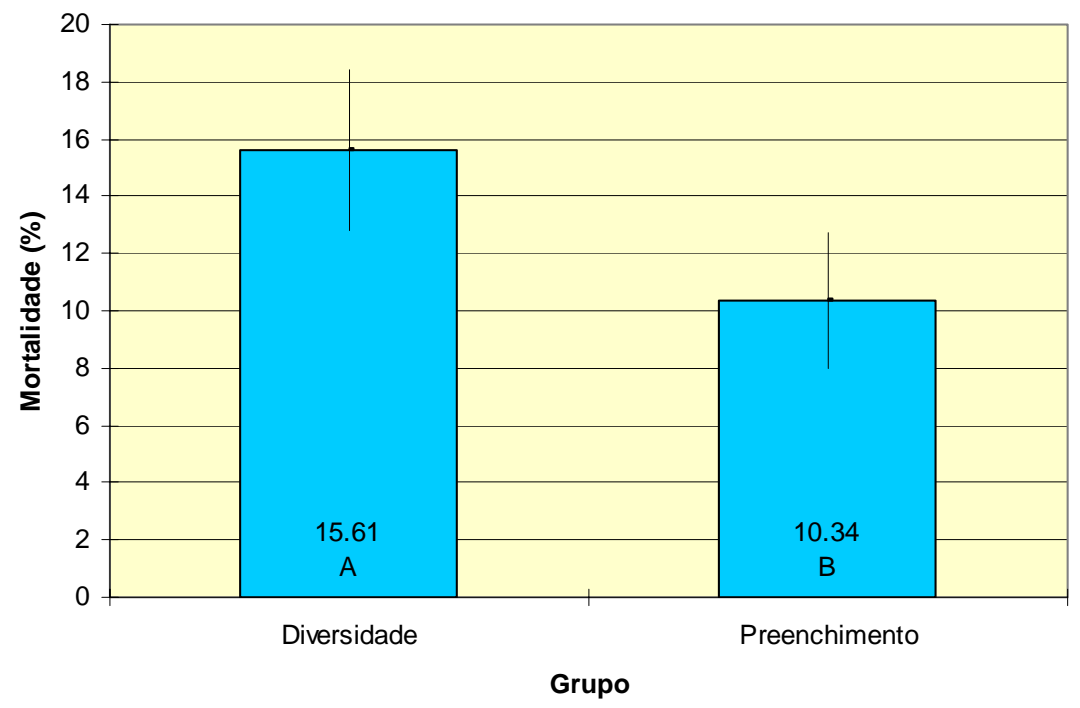

Figura 7 - Porcentagem de Mortalidade dos indivíduos dos grupos de Preenchimento e Diversidade (Médias e intervalos de confiança da variável Mortalidade (\%)).Barras com a mesma letra não diferem entre si através do teste de Tukey ou da análise de variância com nível de significância de $5 \%$

Dependendo do clima regional, das condições edáficas e até do manejo da área restaurada, algumas espécies e conseqüentemente seus respectivos grupos podem se comportar de maneira diferente (Barbosa, 2004). A Tabela 4 mostra os resultados do trabalho de Araújo et al., (2004) na região de Morro Agudo, SP, o qual usou a mesma metodologia de amostragem em três plantios de diferentes idades implantados com o mesmo modelo de restauração deste trabalho.

Tabela 4. Idade do plantio, porcentagem de mortalidade, espaçamento médio entre plantas na mesma linha de plantio e porcentagem de cobertura nos dois grupos de plantio para a idade de 1,2 e 3 anos em Morro Agudo, SP

\begin{tabular}{lcccc}
\hline Grupo de plantio & $\begin{array}{c}\text { Idade do } \\
\text { plantio }\end{array}$ & $\begin{array}{c}\text { Espaçamento } \\
\text { Médio (linha) }\end{array}$ & $\begin{array}{c}\text { Cobertura } \\
\text { \% }\end{array}$ & $\begin{array}{c}\text { Diferença dos } \\
\text { grupos \% }\end{array}$ \\
\hline Diversidade & 1 & $2,0 \times 3,0$ & 44,6 & 114,35 \\
Preenchimento & 1 & $2,0 \times 3,0$ & 95,6 & \\
Diversidade & 2 & $2,0 \times 3,0$ & 104,2 & 31,28 \\
Preenchimento & 2 & $2,0 \times 3,0$ & 136,8 & \\
Diversidade & 3 & $2,0 \times 3,0$ & 139,2 & 18,50 \\
Preenchimento & 3 & $2,0 \times 3,0$ & 165,0 & \\
Fonte: Araújo et al., (2004) & & & &
\end{tabular}


Quando comparamos os dados obtidos por Araújo et al., (2004) com os dados obtidos neste trabalho, chama atenção a diferença de crescimento entre os grupos de plantio. Aos 3 anos de plantio, o grupo de Preenchimento em Morro Agudo, SP, possui $165 \%$ de cobertura, enquanto aos 2,5 anos a cobertura chega apenas a 109,2\% neste trabalho, sendo uma diferença de $51,1 \%$ entre as duas coberturas. A diferença entre a cobertura dos grupos de diversidade ainda é bem maior, sendo 139,2\% em Morro Agudo e 59,6\% neste trabalho, ou seja, 133,6\% maior em Morro Agudo.

As diferenças são bem menores quando comparamos os plantios de 1 ano em Morro Agudo e 1,5 anos deste trabalho. No primeiro ano de plantio o grupo de Preenchimento em Morro Agudo possui 95,6\% de cobertura, enquanto com 1,5 anos a cobertura chega a $81,6 \%$ neste trabalho, diferença de $17,2 \%$ entre as duas coberturas. A diferença entre a cobertura dos grupos de diversidade é de 44,6\% em Morro Agudo e 47,0\% neste trabalho, ou seja, 5,1\% menor em Morro Agudo.

Apesar das áreas comparadas não terem exatamente a mesma idade, esses valores provavelmente apontam para o aumento da diferença entre o desenvolvimento dos plantios nas duas regiões, principalmente entre um ano e meio e o terceiro ano. Esse aumento no desenvolvimento reflete tanto os aspectos climáticos e edáficos envolvidos, quanto a forma de manutenção da área implantada. A área estudada neste trabalho, situada no município de Ribeirão Grande, além de estar situada em uma região fria com clima subtropical, sujeita a geadas e temperaturas médias anuais de $18^{\circ} \mathrm{C}$ (Setzer, 1966), apresenta solos pouco férteis e no geral bastante degradados pelas constantes queimadas. Por outro lado, a região de Morro Agudo localiza-se no norte do Estado de São Paulo, com clima tipicamente tropical, onde as temperaturas médias anuais são de $22{ }^{\circ} \mathrm{C}$ (Setzer, 1966) e predomina os latossolos, bastante férteis. Entretanto, a região de Ribeirão Grande apresenta uma ligeira deficiência hídrica no inverno, enquanto em Morro Agudo, a estiagem é bem definida nesse período.

Assim, acreditamos que a manutenção realizada de forma mais intensa no primeiro ano do plantio da Fazenda Intermontes e a não ocorrência de geada neste primeiro 1,5 anos após plantio, permitiram que as diferenças entre os plantios de 1 ano em Morro Agudo e 1,5 anos neste trabalho, não fossem tão marcantes. Já para os 
plantios de 2,5 anos, além de ter 6 meses a menos que o plantio de 3 anos de Morro Agudo, houve também a presença de fortes geadas no primeiro e segundo ano, o que certamente causou danos aos indivíduos plantados retardando o seu desenvolvimento e aumentando a sua mortalidade.

Ainda comparando as duas regiões, chama bastante atenção a mudança das diferenças de coberturas entre os grupos nas diferentes idades de plantio (Tabela 3). Enquanto em Morro Agudo essas diferenças são de 114,35\% no primeiro ano, para $35,5 \%$ no segundo e $18,5 \%$ no terceiro ano, na Fazenda Intermontes, a diferença no plantio com 1,5 anos é de 73,6\% passando para 83,3\% no plantio com 2,5 anos. Essas diferenças sugerem que, na região de Morro Agudo, as espécies do grupo de Preenchimento podem estar criando condições ambientais favoráveis para o desenvolvimento do grupo de Diversidade efetivamente a partir do segundo ano (Souza \& Batista, 2004) e diminuindo as diferenças de cobertura entre os grupos. Por outro lado, na Fazenda Intermontes a diferença de cobertura entre os dois grupos de plantio aumentou juntamente com o aumento da idade de plantio, significando provavelmente que o grupo de Diversidade ainda não encontrou condições favoráveis para seu desenvolvimento. Assim, torna-se interessante o uso desse parâmetro para o monitoramento e a determinação do momento de abandono da manutenção da área em restauração.

Os resultados de cobertura média de copa foram também analisados por espécies que apresentaram mais de 10 indivíduos amostrados, fornecendo informações importantes sobre a classificação da espécie no seu grupo de plantio. Com essas informações pretendemos avaliar se as espécies foram classificadas corretamente ou não através dos resultados de análise de agrupamento (Figura 8), propondo essa metodologia como forma prática para avaliação e, se necessário, reclassificação das espécies em projetos que utilizem modelos semelhantes. 


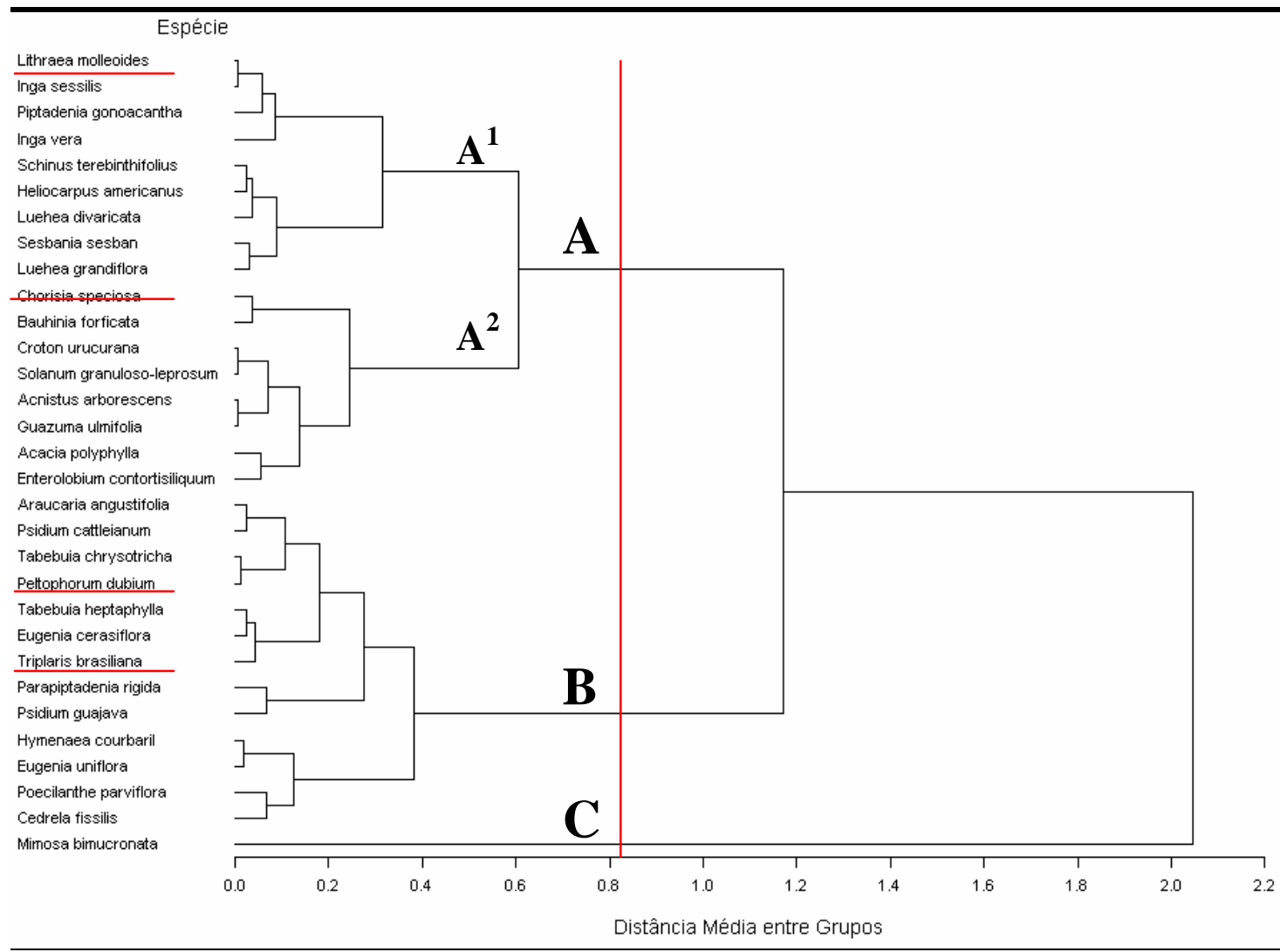

Figura 8 - Dendograma da cobertura média de copas das espécies que apresentaram mais de 10 indivíduos amostrados no reflorestamento com 2,5 anos, construído a partir da análise de agrupamento (Cluster Analysis) original, com indicação de ponto de corte $(0,8)$. Espécies sublinhadas foram classificadas erroneamente pelo LERF no momento do plantio

Cabe ressaltar que, devido às características desses plantios que foram realizados com alta diversidade, apresentando muitas espécies, mas com poucos indivíduos em cada uma delas, das 114 espécies amostradas no plantio com 2,5 anos, apenas 31 espécies apresentaram o número mínimo estabelecido de 10 indivíduos amostrados e puderam ser analisadas. Isso ocorreu principalmente com o grupo de Diversidade, o qual apresentou apenas 13 espécies analisadas, num total de 80 classificadas pelo LERF neste grupo para o reflorestamento com 2,5 anos. Em função disso, seria necessário uma área amostral maior para possibilitar a análise de agrupamento da maioria das espécies plantadas.

O ponto mais interessante para corte foi 0,8 (Figura 8), no qual as espécies formaram 3 grupos. O grupo "A" correspondeu às espécies do grupo de Preenchimento e 
o grupo "B" correspondeu às espécies do grupo da diversidade. Dentro do grupo A é interessante notar uma subdivisão na qual dois subgrupos também apresentam coberturas médias distintas, sendo 2,47 $\mathrm{m}$ para $\mathrm{A}^{1}$ que apresentou 9 espécies e 3,43 m para $\mathrm{A}^{2}$ que apresentou 8 espécies. Essa informação demonstra a possibilidade de utilização de um modelo que privegie as espécies do grupo $\mathrm{A}^{2}$ na linha de Preenchimento, aumentando ainda mais a sua eficiência. Isso pode ser obtido uma vez que a média para o grupo de Prenchimento $\left(A^{1}+A^{2}\right)$ foi $2,8 \mathrm{~m}$, cerca de $0,63 \mathrm{~cm}$ a menos que a média obtida para o subgrupo $\mathrm{A}^{2}$. Nesse modelo, embora a diversidade de espécies no grupo de Prenchimento caia, as espécies do grupo $\mathrm{A}^{1}$ poderiam ser incluídas no grupo de Diversidade, mantendo o número de espécies totais que seriam plantadas.

Em um terceiro grupo, chamado de "C", onde ocorreu apenas à espécie Mimosa bimucronata (maricá) usada no plantio dentro do grupo de Preenchimento. Essa espécie se destaca no dendrograma, formando um grupo independente, devido a sua média de copa ser bastante elevada em comparação a todas as outras $(5,38 \mathrm{~m})$, chegando a ser 47\% maior que a segunda maior média de copa, a da espécie Solanum granulosoleprosum (gravitinga) com 3,66 m. Em função disso, pode-se dizer que essa espécie foi classificada corretamente dentro do grupo de Preenchimento, uma vez que a mesma cumpre a principal função do grupo, que é o sombreamento.

A Tabela 5 apresenta a largura média das copas das espécies com mais de 10 indivíduos amostrados no plantio com 2,5 anos, sua classificação neste plantio e sua reclassificação de acordo com a análise de agrupamento.

Espécies como a paineira (Chorisia speciosa A. St.-Hil.) e aroeira-brava (Lithraea molleoides Engl.), pertencentes ao grupo de Diversidade, a canafístula (Peltophorum dubium Taub.) e o pau-formiga (Triplaris brasiliana Cham.), pertencentes ao grupo de Preenchimento, foram, de acordo com a análise de agrupamento, classificadas erroneamente pelo LERF no momento da implantação dessa metodologia nessa região.

A paineira que foi plantada no grupo da diversidade apresentou uma largura média de copa de 3,1 m, que é superior à largura média das copas das espécies pertencentes ao grupo de Preenchimento $(2,80 \mathrm{~m})$. Em função disso, se a paineira e as 
outras 3 espécies tivessem sido classificadas corretamente nos seus devidos grupos de plantio, as diferenças entre as coberturas dos grupos de preenchimento e diversidade seriam ainda maiores.

Tabela 5. Largura média da projeção das copas de espécies que foram amostradas com mais de 10 indivíduos no plantio com 2,5 anos, G.P.= grupo de plantio; $\mathrm{P}=$ preenchimento; $\mathrm{D}$ = diversidade; R. = reclassificação (baseada na análise de agrupamento Figura - 08)

\begin{tabular}{|c|c|c|c|c|c|c|c|}
\hline Família & Nome Científico & Autor & Nome Popular & $\begin{array}{c}\mathrm{N}^{\mathrm{o}} \\
\text { repetições }\end{array}$ & G.P. & R. & $\begin{array}{l}\text { cober. média } \\
\text { de copa }(\mathrm{m})\end{array}$ \\
\hline Anacardiaceae & Lithraea molleoides & Engl. & Aroeira brava & 58 & $\mathrm{D}$ & $\mathrm{P}$ & 2,18 \\
\hline Anacardiaceae & Schinus terebinthifolius & Raddi & Aroeira pimenteira & 67 & $\mathrm{P}$ & $\mathrm{P}$ & 2,68 \\
\hline Araucariaceae & Araucaria angustifolia & Kuntze & Araucária & 22 & $\mathrm{D}$ & $\mathrm{D}$ & 1,38 \\
\hline Bignoniaceae & Tabebuia chrysotricha & $\begin{array}{l}\text { (Mart. ex A. DC.) } \\
\text { Standl. }\end{array}$ & Ipê amarelo & 10 & $\mathrm{D}$ & $\mathrm{D}$ & 1,19 \\
\hline $\begin{array}{l}\text { Bignoniaceae } \\
\text { Fabaceae }\end{array}$ & Tabebuia heptaphylla & (Vell.) Toledo & Ipê rosa & 10 & $\mathrm{D}$ & $\mathrm{D}$ & 0,98 \\
\hline $\begin{array}{l}\text { Caesalpinioideae } \\
\text { Fabaceae }\end{array}$ & Peltophorum dubium & Taub. & Canafístula & 14 & $\mathrm{P}$ & $\mathrm{D}$ & 1,17 \\
\hline Caesalpinioideae & Hymenaea courbaril & $\mathrm{L}$. & Jatobá & 23 & $\mathrm{D}$ & $\mathrm{D}$ & 0,77 \\
\hline Cercideae & Bauhinia forficata & Link & Pata de vaca & 19 & $\mathrm{P}$ & $\mathrm{P}$ & 3,16 \\
\hline Euphobiaceae & Croton urucurana & Baill. & Sangra d`água & 52 & $\mathrm{P}$ & $\mathrm{P}$ & 3,65 \\
\hline $\begin{array}{l}\text { Fabaceae } \\
\text { Faboideae } \\
\text { Fabaceae }\end{array}$ & Poecilanthe parviflora & Benth. & Coração de negro & 11 & $\mathrm{D}$ & $\mathrm{D}$ & 0,61 \\
\hline Faboideae & Sesbania sesban & Fawc. \& Rendle & Alelueiro & 54 & $\mathrm{P}$ & $\mathrm{P}$ & 2,76 \\
\hline Malvaceae & Chorisia speciosa & A. St.-Hil. & Paineira & 65 & $\mathrm{D}$ & $\mathrm{P}$ & 3,10 \\
\hline Malvaceae & Guazuma ulmifolia & Lam. & Mutambo & 10 & $\mathrm{P}$ & $\mathrm{P}$ & 3,53 \\
\hline Malvaceae & Heliocarpus americanus & $\mathrm{L}$. & Pau jangada & 43 & $\mathrm{P}$ & $\mathrm{P}$ & 2,64 \\
\hline Malvaceae & Luehea divaricata & Mart. & Açoita cavalo & 64 & $\mathrm{P}$ & $\mathrm{P}$ & 2,60 \\
\hline Malvaceae & Luehea grandiflora & Mart. & Açoita cavalo 2 & 14 & $\mathrm{P}$ & $\mathrm{P}$ & 2,86 \\
\hline $\begin{array}{l}\text { Meliaceae } \\
\text { Fabaceae }\end{array}$ & Cedrela fissilis & Vell. & Cedro & 42 & $\mathrm{D}$ & $\mathrm{D}$ & 0,50 \\
\hline $\begin{array}{l}\text { Mimosoideae } \\
\text { Fabaceae }\end{array}$ & Inga sessilis & (Vell).Mart & Ingá ferradura & 29 & $\mathrm{P}$ & $\mathrm{P}$ & 2,19 \\
\hline $\begin{array}{l}\text { Mimosoideae } \\
\text { Fabaceae }\end{array}$ & Inga vera & Willd. & Ingá & 43 & $\mathrm{P}$ & $\mathrm{P}$ & 2,08 \\
\hline $\begin{array}{l}\text { Mimosoideae } \\
\text { Fabaceae }\end{array}$ & Mimosa bimucronata & (DC.) Kuntze & Maricá & 14 & $\mathrm{P}$ & $\mathrm{P}$ & 5,38 \\
\hline $\begin{array}{l}\text { Mimosoideae } \\
\text { Fabaceae }\end{array}$ & $\begin{array}{l}\text { Acacia polyphylla } \\
\text { Enterolobium }\end{array}$ & $\mathrm{DC}$. & Monjoleiro & 18 & $\mathrm{P}$ & $\mathrm{P}$ & 3,33 \\
\hline $\begin{array}{l}\text { Mimosoideae } \\
\text { Fabaceae }\end{array}$ & contortisiliquum & (Vell). Morong & Orelha de negro & 13 & $\mathrm{P}$ & $\mathrm{P}$ & 3,42 \\
\hline $\begin{array}{l}\text { Mimosoideae } \\
\text { Fabaceae }\end{array}$ & Parapiptadenia rigida & (Benth.) Brenan & Guarucaia & 18 & $\mathrm{D}$ & $\mathrm{D}$ & 1,52 \\
\hline Mimosoideae & Piptadenia gonoacantha & (Mart.) J.F. Macbr. & Pau jacaré & 24 & $\mathrm{P}$ & $\mathrm{P}$ & 2,28 \\
\hline Myrtaceae & Eugenia cerasiflora & Miq. & & 11 & $\mathrm{D}$ & $\mathrm{D}$ & 0,94 \\
\hline Myrtaceae & Eugenia uniflora & L. & Pitanga & 18 & $\mathrm{D}$ & $\mathrm{D}$ & 0,74 \\
\hline Myrtaceae & Psidium guajava & L. & Goiabeira & 12 & $\mathrm{D}$ & $\mathrm{D}$ & 1,63 \\
\hline Myrtaceae & Psidium cattleianum & Sabine & Araçá & 19 & $\mathrm{D}$ & $\mathrm{D}$ & 1,34 \\
\hline Polygonaceae & Triplaris brasiliana & Cham. & Pau formiga & 17 & $\mathrm{P}$ & $\mathrm{D}$ & 1,03 \\
\hline Solanaceae & Acnistus arborescens & (L.) Schltdl & Fumo bravo & 25 & $\mathrm{P}$ & $\mathrm{P}$ & 3,57 \\
\hline Solanaceae & leprosum & Dunal & Gravitinga & 15 & $\mathrm{P}$ & $\mathrm{P}$ & 3,66 \\
\hline
\end{tabular}


$\mathrm{Na}$ busca pela diversidade dos plantios, é normal que algumas espécies sejam classificadas erroneamente, principalmente pelo desconhecimento de suas características arquiteturais e de crescimento ou ainda a resposta de certas espécies a características edáficas, climáticas e de manutenção da área em restauração. Barbosa (2004) relata que pode ocorrer comportamento diferenciado de uma mesma espécie quando plantada em locais diferentes, em função da variação de alguma característica específica do sítio. Os diferentes comportamentos podem ocorrer em função de interações entre o genótipo e o ambiente, razão pela qual não se recomenda a generalização das informações sobre o comportamento das espécies de uma região para outro. Entretanto, mesmo com algumas classificações errôneas, os resultados finais não apresentaram o comprometimento das funções dos grupos de preenchimento e diversidade.

Da mesma forma, o grupo das espécies pioneiras foi recomendado em vários modelos de restauração com o objetivo principal de sombreamento (Kageyama, 1986; Kageyama et al., 1990; 1994; Barbosa, 2004; Kageyama \& Gandara; 2004). Entretanto, a Tabela 6 mostra que o uso de algumas espécies citadas na literatura como pioneiras ou secundárias iniciais, com o objetivo de sombreamento, podem não apresentar essas funções nas condições em que foram estudadas neste trabalho. Entre elas temos a canafístula (Peltophorum dubium Taub.), o araçá (Psidum cattleianum) e o pau-formiga (Triplaris brasiliana Cham.). Essas espécies foram identificadas pela análise de agrupamento como pertencentes ao grupo de Diversidade. Outras espécies nativas classificadas como pioneiras como a embaúba (Cecropia pachystachia), a capororoca (Rapanea umbellata), o dedaleiro (Lafoensia pacari), o jerivá (Syagrus romanzoffiana), a mamica de porca (Zanthoxylum riedelianum), a lixeira (Aloysia virgata), entre outras, podem apresentar o mesmo comportamento (Figura 9).

Tabela 6. Relação entre os grupos de plantio e os grupos ecológicos (Budowski, 1965) das espécies com mais de 10 indivíduos amostrados. N.C. $=$ não classificada

\begin{tabular}{lcccccc}
\hline $\begin{array}{l}\text { Grupos de } \\
\text { plantio }\end{array}$ & $\begin{array}{c}\text { Total de } \\
\text { espécies }\end{array}$ & Pioneira & $\begin{array}{c}\text { Secundária } \\
\text { Inicial }\end{array}$ & $\begin{array}{c}\text { Secundária } \\
\text { tardia }\end{array}$ & Climácicas & N.C. \\
\hline Preenchimento & 18 & 11 & 3 & 2 & - & 2 \\
Diversidade & 13 & 3 & 1 & 7 & - & 2 \\
\hline
\end{tabular}


Por outro lado, 2 espécies classificadas na literatura como pertencentes ao grupo das secundárias tardias, a paineira (Chorisia speciosa) e o ingá (Inga sessilis), se apresentaram, na fase inicial de seu desenvolvimento, como boas sombreadoras.

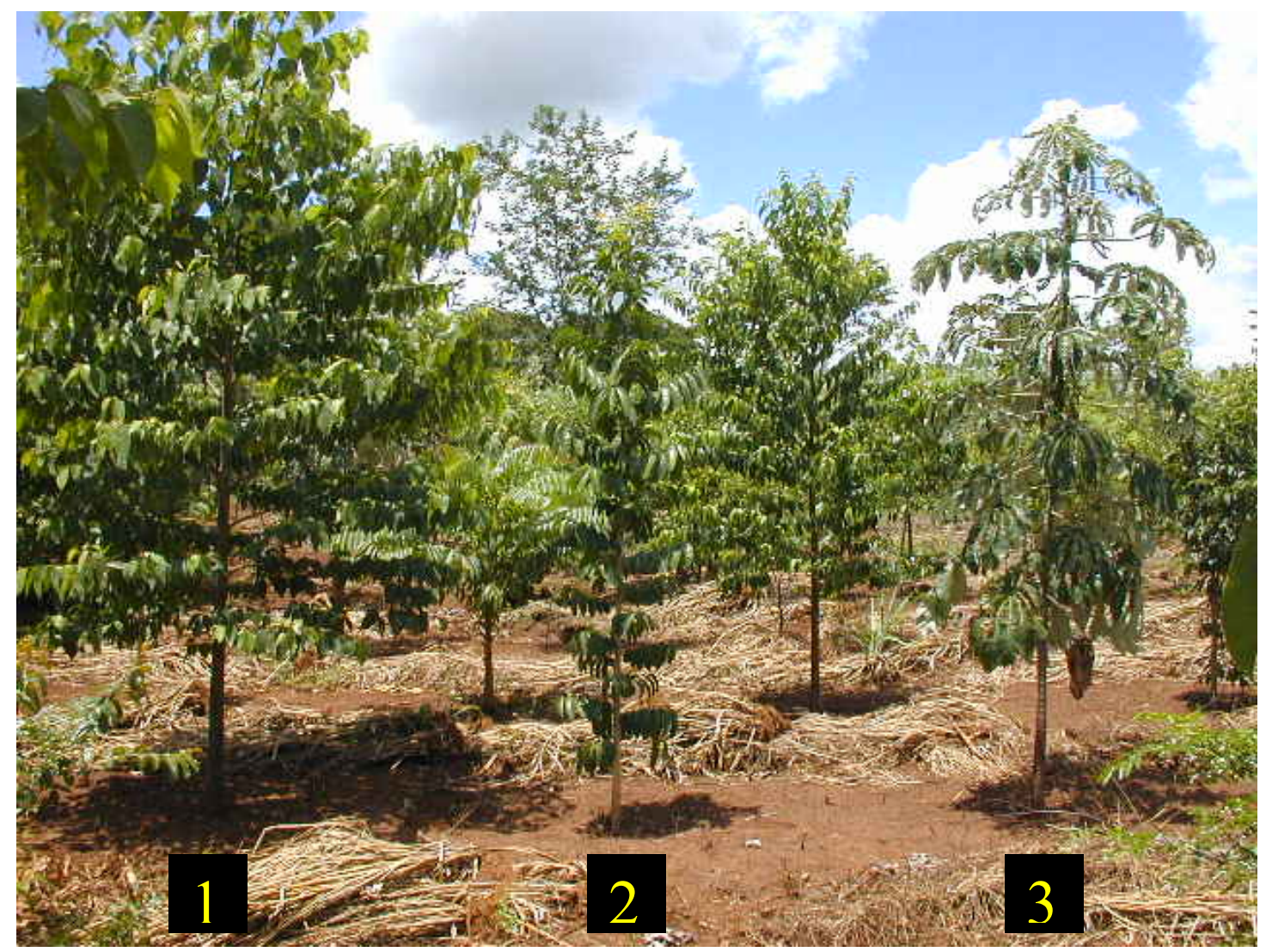

Figura 9 - Sombreamento diferenciado na linha de pioneiras de 3 espécies iniciais de sucessão com um ano de plantio: 1) Mutambo (Guazuma ulmifolia); 2) Mamica-de-porca (Zanthoxylum riedelianum); 3) Embaúba (Cecropia pachystachia). Fazenda Porto Velho, Orindiúva, SP

O estudo realizado por Barbosa et al. (1996) em áreas restauradas, usando parâmetros como: altura total, diâmetro da copa e a circunferência do caule a altura do peito (CAP), conclui que várias espécies pioneiras usadas como sombreadoras, na verdade não possuíam essa função. Os autores chegaram a propor mudanças nas classificações sucessionais de várias espécies em função do comportamento desses parâmetros em campo. O mesmo ocorreu no trabalho de Rodrigues et al., (1999). 
Dessa forma, as informações sobre o crescimento e a largura média da copa das espécies nos primeiros anos são fundamentais para sua classificação dentro dos grupos de preenchimento e diversidade, assim como a média da largura da copa de cada grupo de plantio é importante para uma reavaliação sobre o espaçamento e arranjo dos grupos em atividades de restauração. Nesse sentido, são apresentados nas Figuras 10, 11 e 12, três desenhos esquemáticos usando as médias de cobertura de copas, obtidas pelos dois grupos de plantio. A partir dessa simulação de modelos, contendo arranjos e espaçamentos diferentes entre os grupos de plantio, foi possível obter dados de cobertura total e sobreposição de copas (Tabela 7), permitindo a proposição de modelos de plantio provavelmente mais eficientes e conseqüentemente menos onerosos.

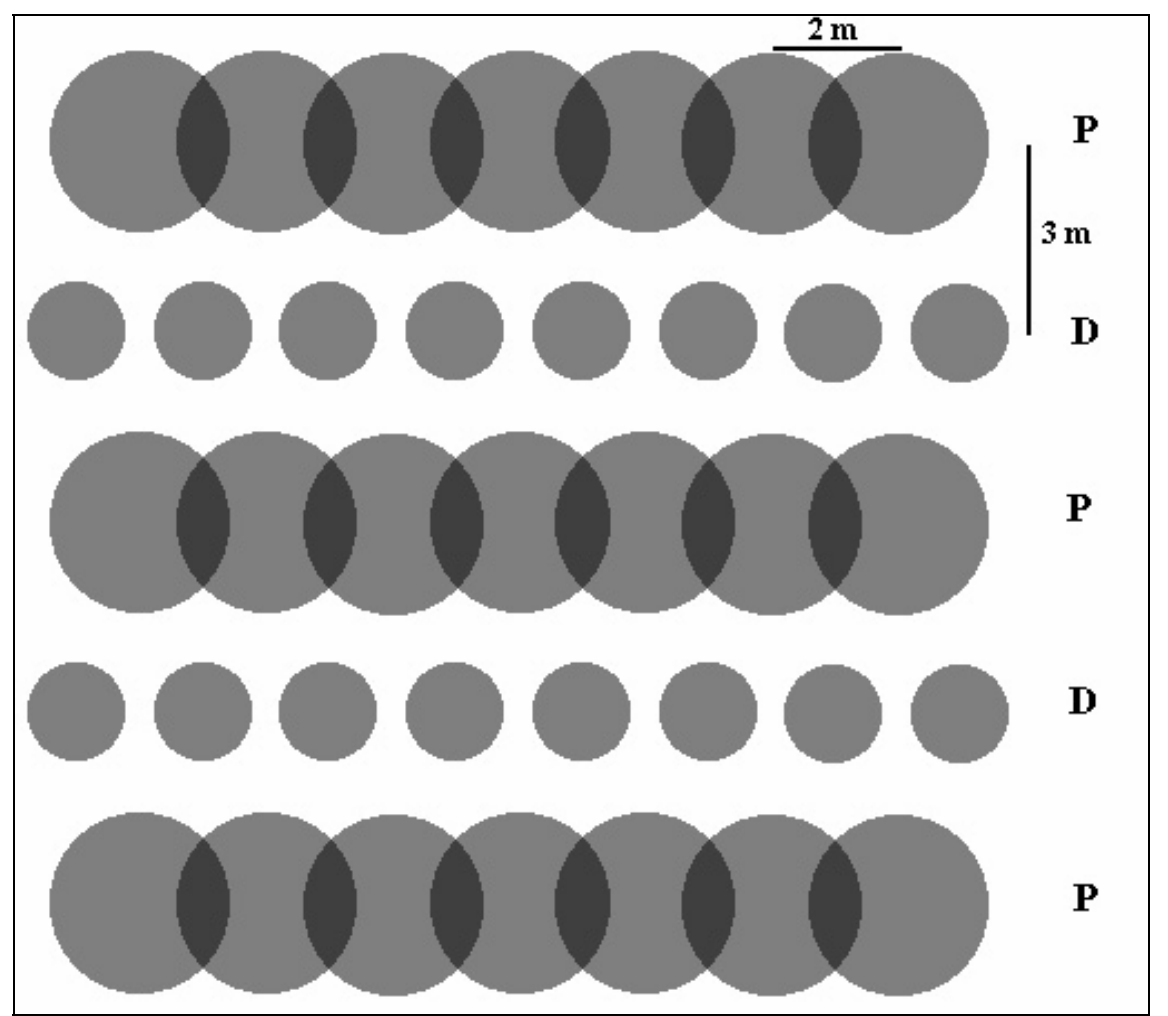

Figura 10 - Modelo A - situação de plantio simulada usando linhas alternadas dos grupos de plantio e a média do diâmetro da projeção das copas (Preenchimento $=2,80$, Diversidade $1,56 \mathrm{~m}$ ) obtidas no plantio da área com 2,5 anos e espaçamento tradicional de 3 entre linhas por 2 entre plantas 


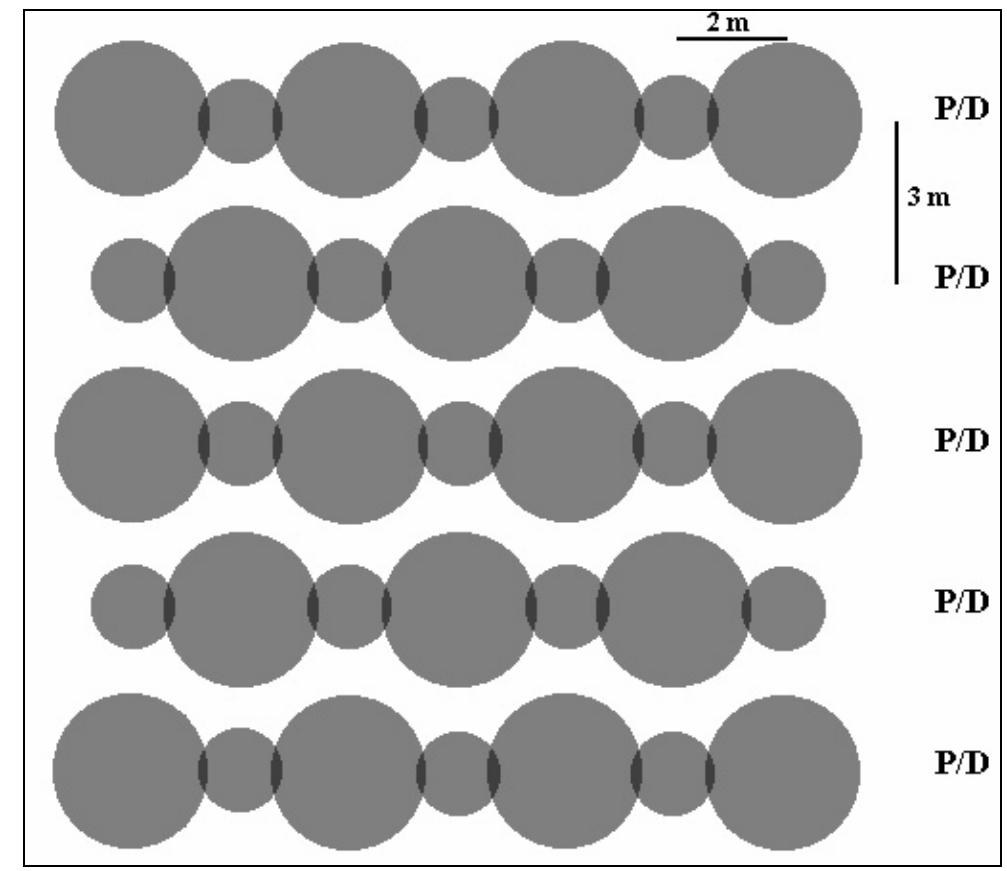

Figura 11 - Modelo B - situação de plantio simulada usando os grupos de plantio de forma alternada na mesma linha e a média do diâmetro da projeção das copas (Preenchimento $=2,80$, Diversidade 1,56 m) obtidas no plantio da área com 2,5 anos e espaçamento tradicional de 3 entre linhas por 2 entre plantas

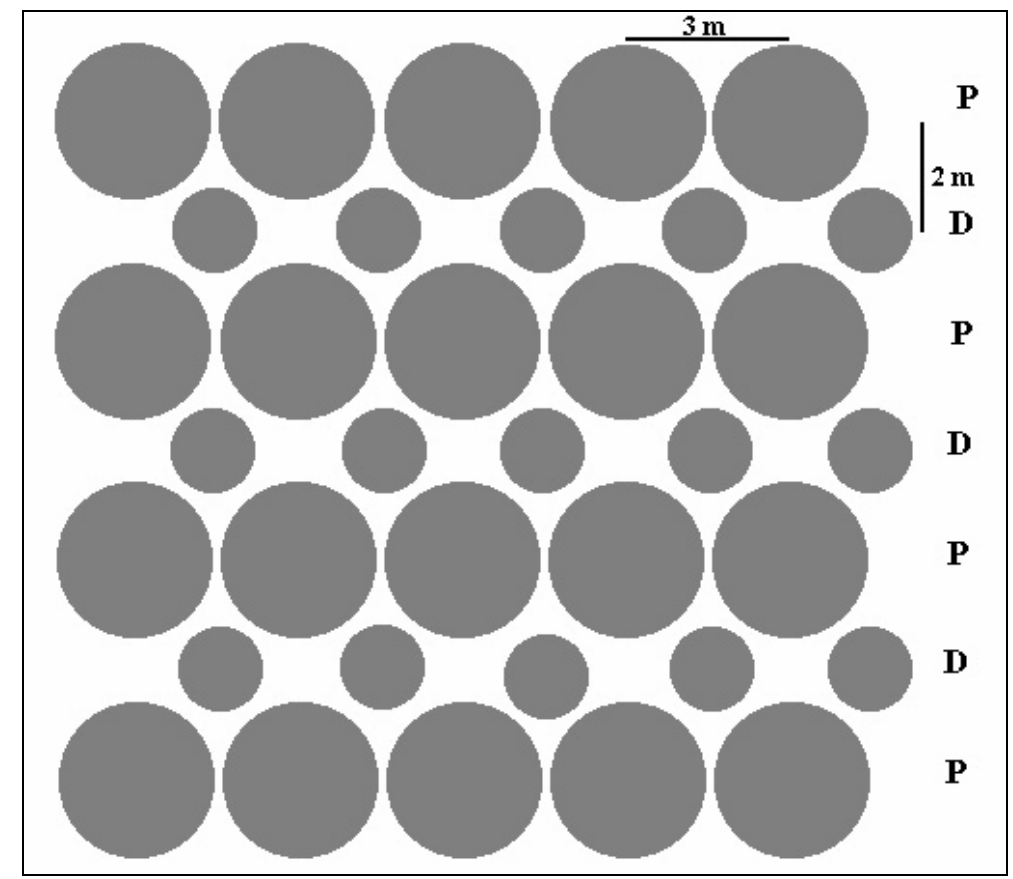

Figura 12 - Modelo C - situação de plantio simulada usando linhas alternadas dos grupos de plantio e a média do diâmetro da projeção das copas (Preenchimento = 2,80, Diversidade 1,56 m) obtidas no plantio da área com 2,5 anos e espaçamento de 2 entre linhas por 3 entre plantas 
Tabela 7. Dados gerais obtidos através da simulação de modelos contendo arranjos e espaçamentos diferentes entre os grupos de plantio e usando a média do diâmetro da projeção das copas (Preenchimento $=2,80$, Diversidade 1,56 m) obtidas no plantio da área com 2,5 anos

\begin{tabular}{lccc}
\hline Modelos & A & B & C \\
\hline Espaçamento & $3 \times 2 \mathrm{~m}$ & $3 \times 2 \mathrm{~m}$ & $2 \times 3 \mathrm{~m}$ \\
Plantas por ha & 1667 & 1667 & 1667 \\
Cobertura do & 59,68 & 67,33 & 69,32 \\
$\begin{array}{l}\text { solo \% } \\
\begin{array}{l}\text { Sobreposição } \\
\text { de copas \% }\end{array}\end{array}$ & 10,00 & 2,05 & 0,0 \\
\hline
\end{tabular}

Os resultados da simulação de modelos de plantio mostraram que a metodologia utilizada no Modelo A (Tabela 7), utilizada no reflorestamento da Intermontes, foi a menos eficaz em termos de cobertura do solo. Os Modelos B e C (Tabela 7) apresentaram coberturas significativamente maiores que o Modelo A. A maneira como os grupos estão arranjados no Modelo A sugerem ainda, um incremento da competição entre os indivíduos pertencentes ao grupo de Preenchimento, pois suas copas apresentam 5,9\% de sobreposição, explicitando uma competição por espaço e por luz além da provável competição por nutrientes no solo. A Figura 13 mostra a sobreposição das copas na linha de preenchimento do plantio com 2,5 anos. Segundo Kageyama (1990), um experimento utilizando apenas espécies iniciais apresentou desenvolvimento menor deste grupo do que utilizando a consorciação de pioneiras (pioneiras típicas e secundárias iniciais) e não-pioneiras (secundárias tardias e climáces).

$\mathrm{O}$ arranjo dos grupos dos Modelos $\mathrm{B}$ e C (Tabela 7) mostraram a não sobreposição das copas, demonstrando uma menor competição entre os indivíduos dos dois grupos de plantio. Essa menor competição entre indivíduos sugere ainda que nestes modelos B e C, o desenvolvimento em tamanho e largura das copas poderão apresentar, no campo, resultados ainda maiores do que foi apresentado no modelo teórico. No entanto, o Modelo B leva vantagem de poder ser mecanizável nas suas entrelinhas, pois permanece com $3 \mathrm{~m}$ de largura, permitindo a entrada de trator para roçagem no início do reflorestamento. Já o Modelo C limita esta mecanização a tratores de pequeno porte. 


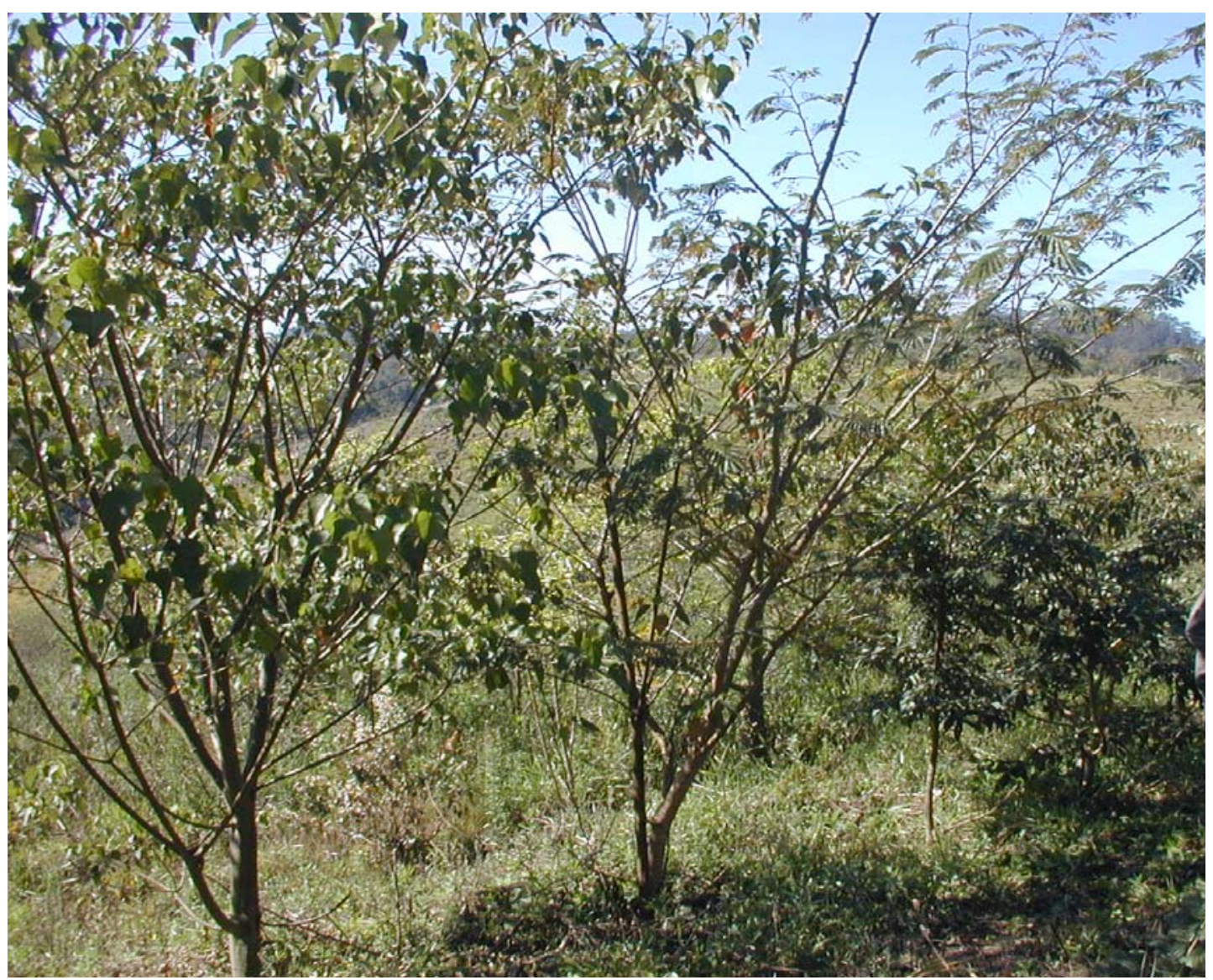

Figura 13 - Competição por luz, nutrientes e espaço entre indivíduos de sangra d'água, monjoleiro e ingá na linha de Preenchimento, Fazenda Intermontes, CCRG, município de Ribeirão Grande, SP

Vale ressaltar que se o Modelo B tivesse seu espaçamento 2 × 2 m apresentaria uma cobertura com 97,5\%, devido ao estreitamento do espaçamento entre linhas. Esse Modelo B (com espaçamento 2 x 2m) certamente apresentaria um custo de implantação mais elevado que os outros modelos devido à maior densidade das mudas plantadas, entretanto, apresentaria menor manutenção da área implantada, podendo compensar financeiramente o investimento inicial. Outra vantagem deste Modelo B (com espaçamento $2 \times 2 \mathrm{~m}$ ) seria a rápida criação de um ambiente favorável para o aparecimento da regeneração natural, uma vez que o fechamento do dossel permitirá o aumento da umidade e diminuição da competição com espécies exóticas agressivas como, por exemplo, a braquiária e o colonião (Parrota, 1995, Parrota et al., 1997, Souza 
\& Batista, 2004). Os modelos sugeridos deverão ser testados para comprovar sua eficácia.

\subsection{Conclusões}

- No total foram amostrados, nas duas idades de plantio, 2.787 indivíduos pertencentes a 143 espécies e 45 famílias botânicas, sendo 35 espécies pertencentes ao grupo de Preenchimento e 108 espécies pertencentes ao grupo de Diversidade. Esses valores mostraram a possibilidade de implantação de projetos de restauração com elevada diversidade e o efetivo estabelecimento desse elevado número de espécies, demonstrando que a função do grupo da diversidade vem sendo mantida, aumentando as possibilidades de restauração dos processos ecológicos e perpetuação da área restaurada, ou seja, do sucesso da iniciativa.

- Os resultados mostraram que o grupo de Preenchimento apresentou-se com uma porcentagem de cobertura significativamente maior que a do grupo de Diversidade, cumprindo sua principal função no processo de restauração. Isso ocorreu tanto para o reflorestamento com a idade de 1,5 anos como para o reflorestamento com a idade de 2,5 anos, sendo que para 1,5 anos a diferença de cobertura foi de $73,6 \%$ maior para o grupo de Preenchimento em relação ao grupo de Diversidade e para 2,5 anos essa diferença foi de $83,3 \%$.

- Dessa forma, pode-se concluir que foi possível combinar as espécies florestais com alta diversidade em grupos de preenchimento e diversidade, obtendo um rápido e efetivo recobrimento da área em restauração, reduzindo os custos de manutenção dessa restauração e aumentando suas possibilidades de sucesso.

- A metodologia utilizada neste trabalho para quantificar a eficiência da utilização do dois grupos de plantio mostrou-se bastante prática e rápida na aplicação de campo, podendo ser usada nas atividades de avaliação e monitoramento de projetos de restauração, inclusive pelos órgãos de fiscalização.

- A obtenção de parâmetros individuais tornou possível a avaliação do desenvolvimento específico de cada espécie e, quando necessário, à reclassificação da 
espécie nos grupos de plantio através da análise de agrupamento, o que ocorreu com quatro espécies neste trabalho.

- A simulação de modelos de plantio com diferentes arranjos, espaçamentos entre plantas e usando os parâmetros de cobertura média dos indivíduos dos dois grupos de plantio, mostrou a possibilidade do modelo utilizado ser melhorado no sentido de aumentar a eficiência do recobrimento da área, através da menor competição entre os indivíduos plantados. Dessa forma, esses novos modelos teóricos deverão ser testados em campo para comprovar a sua maior eficácia. 


\title{
7 RESTAURAÇÃO FLORESTAL DA FAZENDA INTERMONTES: QUATRO ANOS DE EVOLUÇÃO DA PAISAGEM
}

\author{
Resumo
}

Na avaliação de projetos de restauração é necessária a obtenção de parâmetros de avaliação e monitoramento que permitam a confirmação de que as ações de restauração implantadas em uma determinada área estão efetivamente promovendo a sua recuperação. Essa confirmação ocorrerá através da análise de indicadores que permitam constatar a ocupação gradual e crescente da área, por indivíduos de espécies nativas com diversidade. Neste trabalho, foram usados indicadores de evolução da vegetação na paisagem, com o objetivo de demonstrar a evolução da ocupação de áreas agrícolas por áreas restauradas com vegetação natural. O monitoramento da evolução da paisagem foi realizado através da edição anual do mapa da propriedade, contendo a evolução das situações ambientais destinadas à restauração, com diferentes metodologias, permitindo ainda a sua caracterização e quantificação. A Fazenda Intermontes teve suas áreas divididas em 6 principais situações: a) Pasto sem regeneração natural; b) Pasto com regeneração arbustiva; c) Pasto com regeneração arbórea; d) Capoeira; e) Floresta e; f) Solo sem vegetação. As situações de floresta e capoeira se destacam em termos de expansão de área ocupada nos quatro anos de análise, sendo 70,2\% e 64\% de aumento, respectivamente. As situações de maior degradação, como solo sem vegetação, pasto sem regeneração natural e pasto com regeneração arbórea, tiveram suas áreas iniciais bastante reduzidas nos quatro anos, sendo $100 \%, 55,70 \%$ e $49,41 \%$ menores, respectivamente. $\mathrm{O}$ trabalho mostrou a importância da retirada dos fatores de degradação 
das situações em restauração. Essa ação pode acelerar os processos de regeneração natural.

Summary

During a restoration project evaluation, the acquirement of key-parameters that confirm if restoring effort are being established and working efficiently should be considered for the different steps of the process. This confirmation may result from the analyses of signs that verify the gradual and increasing area occupation by native individuals. In this study, signs of landscape vegetation development were used to show the evolution of natural vegetation regeneration on agricultural areas. The landscape development monitoring was done through annual edition of the property map, specifying the different environmental situations directed to restoration, its characteristics and quantities. Intermontes farm had its area divided into 6 situations: a) pasture without natural regeneration; b) pasture with shrub regeneration; c) pasture with woody regeneration; d) "capoeira"; e) forest and f) soil lacking vegetation. Forest and "capoeira" situations presented distinguished performance regarding occupation and covered area, with an enhancement of $70,2 \%$ and $64 \%$ respectively. The most degraded situations like pasture with woody regeneration, pasture without natural regeneration and soil lacking vegetation had its covered area diminished in $49,41 \%, 55,70 \%$ and $100 \%$, respectively. This study reinforced the importance of retreating disturbing factors, which can accelerate the natural regeneration processes.

\subsection{Introdução}

$\mathrm{Na}$ avaliação de projetos de restauração, devemos considerar para as diferentes etapas do processo de recuperação, a obtenção de parâmetros de avaliação e monitoramento que permitam a confirmação que as ações de restauração implantadas em uma determinada área estão efetivamente promovendo a sua recuperação. Essa confirmação ocorrerá através da análise de indicadores que permitam constatar a 
ocupação gradual e crescente da área, por indivíduos de espécies nativas, considerando a intensidade com que este processo está ocorrendo no tempo, a cobertura que ele está promovendo na área, a alteração da fisionomia e da diversidade local.

A avaliação e o monitoramento em áreas em processo de restauração abrange aspectos mais amplos do que apenas os fisionômicos normalmente exigidos pelos órgãos fiscalizadores e pelas certificadoras. Os indicadores visam, além da recuperação visual da paisagem, garantir a reconstrução dos processos ecológicos mantenedores da dinâmica vegetal, efetivando a sua perpetuação e seu papel na conservação da biodiversidade local (Rodrigues \& Gandolfi, 2004).

Esses indicadores deverão avaliar não apenas a evolução da restauração natural ou induzida da comunidade, através da expressão e manejo de sua resiliência, mas também apontarão a necessidade e o sucesso das intervenções antrópicas, visando corrigir e/ou garantir que processos críticos para o desencadeamento da sucessão ecológica local ocorram. Nesse sentido, tanto a fisionomia, quanto à composição e a estrutura da comunidade restaurada, considerando os vários estratos e formas de vida, devem ser usados como indicadores de avaliação e monitoramento da vegetação, pois expressam a efetiva restauração dos processos ecológicos e a possibilidade de perpetuação da área.

Dentro desse contexto, podem existir dois tipos de monitoramento: a) $\mathrm{O}$ monitoramento de decisão que permite avaliar de forma mais detalhada, as ações de restauração, reafirmando a efetividade dessas ações ou apontando a necessidade de redefinição dessas ações quando o resultado esperado não foi obtido (Rodrigues \& Gandolfi, 1998). Nesse tipo de monitoramento normalmente são usados parâmetros de composição, estrutura e funcionamento da comunidade e; b) O monitoramento de demonstração que visa apenas documentar e até qualificar e quantificar a evolução de uma paisagem submetida às ações de restauração. Nesse caso, os parâmetros usados são normalmente os fisionômicos.

Os indicadores usados na avaliação e monitoramento da vegetação em formações naturais são na maioria referentes à comunidade (Guevara 1986, Whitmore 1989a), como a riqueza, diversidade e equabilidade vegetal, a fisionomia vegetal, as 
características estruturais dos estratos ou grupos ecológicos, etc. As pesquisas com indicadores populacionais estão apenas começando a ser definidos e seu uso ainda é muito restrito.

Nesse contexto, os indicadores de avaliação e de monitoramento de ecossistemas restaurados são na verdade descritores indiretos da resiliência (Aronson et al., 1993) desses ecossistemas e por isso o maior uso de indicadores comunitários (de um conjunto organizado de espécies), apesar dos populacionais (referentes a uma dada espécie) serem muito promissores, principalmente para espécies tipicamente indicadoras de ambientes ou de estado de organização da comunidade (Rodrigues \& Gandolfi, 1998).

Independente dos tipos de indicadores escolhidos para avaliação e monitoramento de ecossistemas recuperados, eles devem atender os requisitos previamente estabelecidos de: ser facilmente medido; poder ser replicado, ser sensível a mudanças naturais ou antrópicas ao ambiente; predizer mudanças que podem ser evitadas por ações de monitoramento; ser integrativo; ter baixa variabilidade de resposta e outros (Dale \& Beyeler, 2001).

Neste trabalho, foram usados indicadores de evolução da vegetação na paisagem, com o objetivo de demonstrar a evolução da ocupação de áreas agrícolas por áreas restauradas com vegetação natural, comprovando os ganhos ambientais dessa ocupação na Fazenda Intermontes.

Essa alteração da ocupação da paisagem pode ser analisada usando séries temporais de fotografias aéreas, imagens de satélite de média resolução (TM/Landsat) ou alta resolução (IKONOS, SPOT e outros) ou até mesmo através de checagens periódicas de campo, no caso de pequenas propriedades. Essa análise permite produzir mapas de classificação da paisagem, em séries temporais, com representação das situações ambientais, antrópicas ou naturais, classificadas de acordo com o estado de degradação, a posição na paisagem, a ocupação das áreas agrícolas, etc. (Nave, 1999; Korman, 2003; Rodrigues et al., 2004b; Lopes et al., 2004).

A série histórica desses mapas permitirá avaliar a evolução e/ou involução das situações ambientais na paisagem, através de sua correlação com a ocupação antrópica dessas áreas no tempo. 
Segundo o Laboratório de Ecologia e Restauração Florestal (LERF/ESALQ/USP), para definição de benefício ou prejuízo ambiental dessas alterações da paisagem, podem ser usados indicadores como:

a) Variação da porcentagem de cobertura de vegetação natural na unidade ambiental da paisagem (bacia, microbacia) e da propriedade agrícola;

b) Variação da porcentagem de cobertura de vegetação natural na paisagem, considerando os diferentes estádios de degradação dos remanescentes naturais;

c) Posição dessa cobertura natural na paisagem, considerando sua adequação à legislação ambiental e;

d) Posição dessa cobertura natural na paisagem, considerando seus possíveis benefícios ambientais para atuarem como: corredores ecológicos, na proteção de áreas de elevada biodiversidade e/ou de remanescentes naturais bem preservados, na proteção de santuários ambientais, entre outros.

O monitoramento da evolução da paisagem em áreas restauradas é realizado considerando um tempo zero, que deverá ser anterior as ações de restauração. As séries temporais de imagens, que deverão ser objeto dessa classificação, terão intervalos de tempo variáveis para cada propriedade agrícola, e decididos dependendo de seus objetivos e de acordo com suas características de uso histórico e atual.

Sendo assim, o objetivo desses indicadores e também desse trabalho é demonstrar a evolução espacial e temporal da vegetação natural na Fazenda Intermontes, como resultado das intervenções ambientais, de conservação e de restauração de ecossistemas naturais, implantadas nesse intervalo de tempo.

\subsection{Material e Métodos}

7.2.1 Área de estudo

Este trabalho foi desenvolvido na Companhia de Cimento Ribeirão Grande (CCRG), distante aproximadamente 12,5 km ao sul do município de Ribeirão Grande, SP e cerca de $250 \mathrm{~km}$ da cidade de São Paulo (Figura 1). A empresa tem como atividade mineraria a exploração de metacalcários e argila para produção de cimento. 


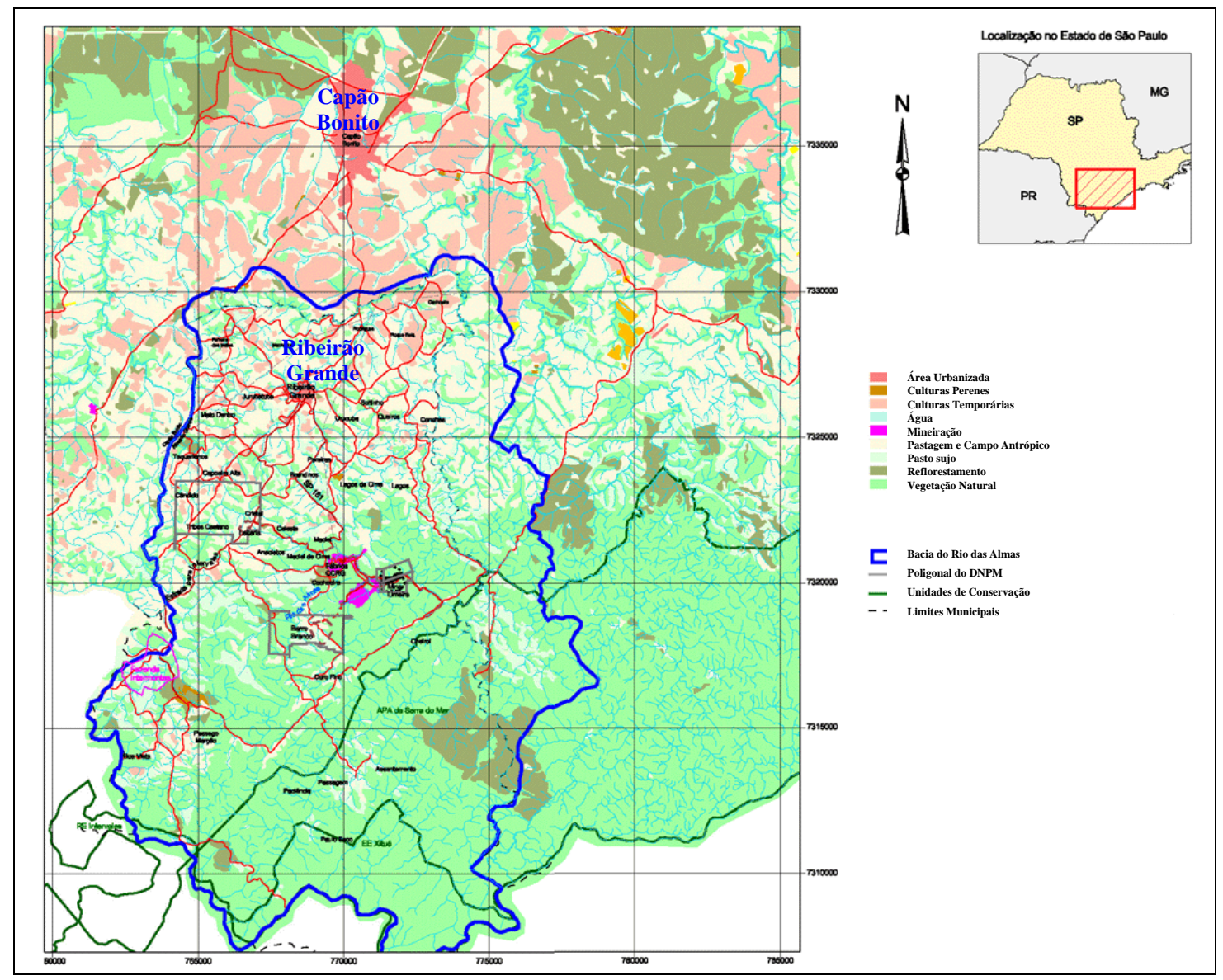

Figura 1 - Localização da Região do município de Ribeirão Grande no Estado de São Paulo.

Com as medidas compensatórias geradas com o corte da vegetação na mina Limeira (autorizada pelo DEPRN em 08/02/2001), a CCRG definiu a restauração da Fazenda Intermontes como local para essas atividades (CCRG, 2003). A Fazenda teve inicialmente um monitoramento da evolução da paisagem realizado pelo Laboratório de Ecologia e Restauração Florestal (LERF), no qual gerou este trabalho.

A Fazenda Intermontes possui 343,0 ha e está localizada na estrada que liga o município de Ribeirão Grande ao Parque Estadual de Intervales, distante aproximadamente $17 \mathrm{~km}$ ao sul do Município de Ribeirão Grande. Sua localização 
geográfica está inserida entre as coordenadas UTM 7.322.500 N; 762.750 L e 7.319.800 $\mathrm{N} ; 760.250 \mathrm{~L}$.

Da mesma forma que ocorreu em toda a região, a vegetação natural da Fazenda Intermontes apresenta trechos de floresta secundária explorada no passado pelo extrativismo seletivo de espécies madeireiras, produção de carvão e possível exploração de palmito (Guix, 1994; Reis et al., 1994).

Atualmente estes trechos de floresta estão confinados em locais bastante íngremes e de difícil acesso, mas ainda bem estruturadas com árvores de grande porte e seus estratos bem definidos. Dentro deste contexto, as áreas identificadas na Fazenda com a situação de floresta entraram dentro do plano de restauração apenas com ações de isolamento e retirada de fatores de degradação, uma vez que estas já se encontravam num estado relativamente avançado de conservação.

Muitas das áreas apresentavam-se como capoeiras, oriundas de trechos anteriormente desmatados, usados como pasto e posteriormente abandonados. Encontrase ainda em determinados locais da Fazenda, ruínas de fornos usados na produção de carvão.

No início deste trabalho, as áreas produtivas da Fazenda eram compostas apenas por pastos classificados neste trabalho em 3 situações diferenciadas: a) pasto sem regeneração natural, o qual apresentava-se desprovido de espécies nativas regenerantes e eram de uso intenso pelo gado; b) pasto com regeneração arbustiva, o qual apresentava em meio a braquiária muitos indivíduos regenerantes compostos principalmente por maria-mole (Senecio brasiliensis (Spreng.) Less.), Vassoura (Baccharis spp) e Solanum variabile Mart.; c) pasto com regeneração arbórea, o qual apresentava-se com regeneração arbustivo-arbórea e encontrava-se principalmente em locais muito íngremes (de difícil manutenção) ou pouco usado pelo gado.

Era prática na região, inclusive na Fazenda Intermontes, a queima das áreas de pasto para renovação do capim, empobrecendo o solo e impedindo a regeneração natural. Após o início do projeto de restauração no ano de 2001, as primeiras medidas adotadas, para a maior parte da Fazenda, foram à retirada do gado e a proteção da área contra incêndios. 
A área em estudo está inserida na Província Geomorfológica do Planalto Atlântico, Zona do Planalto de Guapiara, que compreende a região elevada do alto da Serra de Paranapiacaba e estende-se até a cobertura sedimentar da bacia do Paraná. A região comporta os afluentes de alto curso da margem esquerda do Paranapanema, cuja borda sul marca o divisor de águas da drenagem continental (Vale do Paranapanema) e da litorânea (Vale do Ribeira) (CCRG, 2003)

A declividade dominante está entre 20 a $30 \%$, onde os fundos dos vales estão acima de $800 \mathrm{~m}$ de altitude e os espigões muitas vezes ultrapassam $1.000 \mathrm{~m}$ de altitude (CCRG, 2003).

Essas características definem para região, segundo a classificação de Köeppen (1948), o clima temperado úmido sem estiagem (Cfb), que ocupa áreas do Planalto de Guapiara com altitudes superiores a $800 \mathrm{~m}$. Nessa parte mais alta da Serra de Paranapiacaba as temperaturas médias são inferiores a $18^{\circ} \mathrm{C}$ no mês mais frio e inferiores a $22^{\circ} \mathrm{C}$ no mês mais quente (Nimer, 1989; Setzer, 1966).

A precipitação média da bacia do córrego do chapéu, situada a cerca de $10 \mathrm{~km} \mathrm{da}$ Fazenda Intermontes, é de $1.300 \mathrm{~mm}$, variando de 1.100 e $1.500 \mathrm{~mm}$ por ano, com chuvas concentradas no verão, principalmente nos meses de dezembro, janeiro e fevereiro. Nessa região o período correspondente ao inverno é o que apresenta a maior redução dos índices pluviométricos. O total pluviométrico do mês mais seco é superior a $30 \mathrm{~mm}$ (CCRG, 2003). As temperaturas mínimas absolutas anuais chegam a $-4{ }^{\circ} \mathrm{C}$, nas altitudes mais elevadas, ocorrendo em média de um a cinco dias de geadas por ano (Nimer, 1989; Setzer, 1966).

\subsubsection{A vegetação regional}

A vegetação do município de Ribeirão Grande localiza-se no Planalto Atlântico do Estado de São Paulo, na divisa com a Província Costeira, próxima a escarpa do Planalto Atlântico, onde predomina a Floresta Estacional Semidecidual, mas devido à proximidade com a Serra de Paranapiacaba, apresenta muitas espécies típicas da Floresta Ombrófila Densa na composição florística local (CCRG, 2003). 
A flora regional tem contribuições de várias formações. Na região do Parque Estadual de Intervales ocorrem as chamadas Florestas Ombrófilas, por desenvolveremse em clima úmido sem período de estiagem (Mantovani, 1994). No reverso da Serra de Paranapiacaba, estende-se até Capão Bonito, o estremo norte do domínio da Floresta de Araucárias, formação dos climas temperados quentes e úmidos ou subtropicais úmidos do Sul do Brasil (Klein, 1984). Nas drenagens do Vale do Paranapanema, originam-se provavelmente as espécies típicas de Floresta Estacional Semidecidual do interior dos Estados de São Paulo, Paraná e Minas Gerais (Mantovani, 1994).

As florestas da região encontram-se em estádios diferenciados de sucessão, resultado de ocupação para prática de agricultura por períodos variáveis e pela extração seletiva de madeira e do palmiteiro (Mantovani, 1994). Geralmente os trechos florestais mais bem conservados encontram-se nas encostas mais íngremes ou em locais de difícil acesso.

7.2.3 Utilização do Zoneamento Ambiental como ferramenta para a determinação das diferentes situações ambientais e monitoramento das áreas destinadas à restauração

O Zoneamento Ambiental foi realizado através da caracterização do tipo de ocupação atual, sendo baseado principalmente nas potencialidades de recuperação dessas áreas. Isso permitiu a definição de ações diferenciadas de restauração para cada uma das situações identificadas, visando desencadear e conduzir os processos naturais de restauração. Dessa forma, parte da vegetação natural poderá se restabelecer a partir da regeneração natural, se esta for adequadamente induzida e conduzida em ações de manejo. Isso tem como conseqüência não só a redução dos custos da adequação ambiental, mas também, maior garantia de sucesso dessas ações (Rodrigues et al., 2004b).

O Zoneamento Ambiental foi realizado através da análise de fotografias aéreas da propriedade, coloridas, nas escalas de 1:10.000, tiradas no ano de 1999 (Figura 2). 


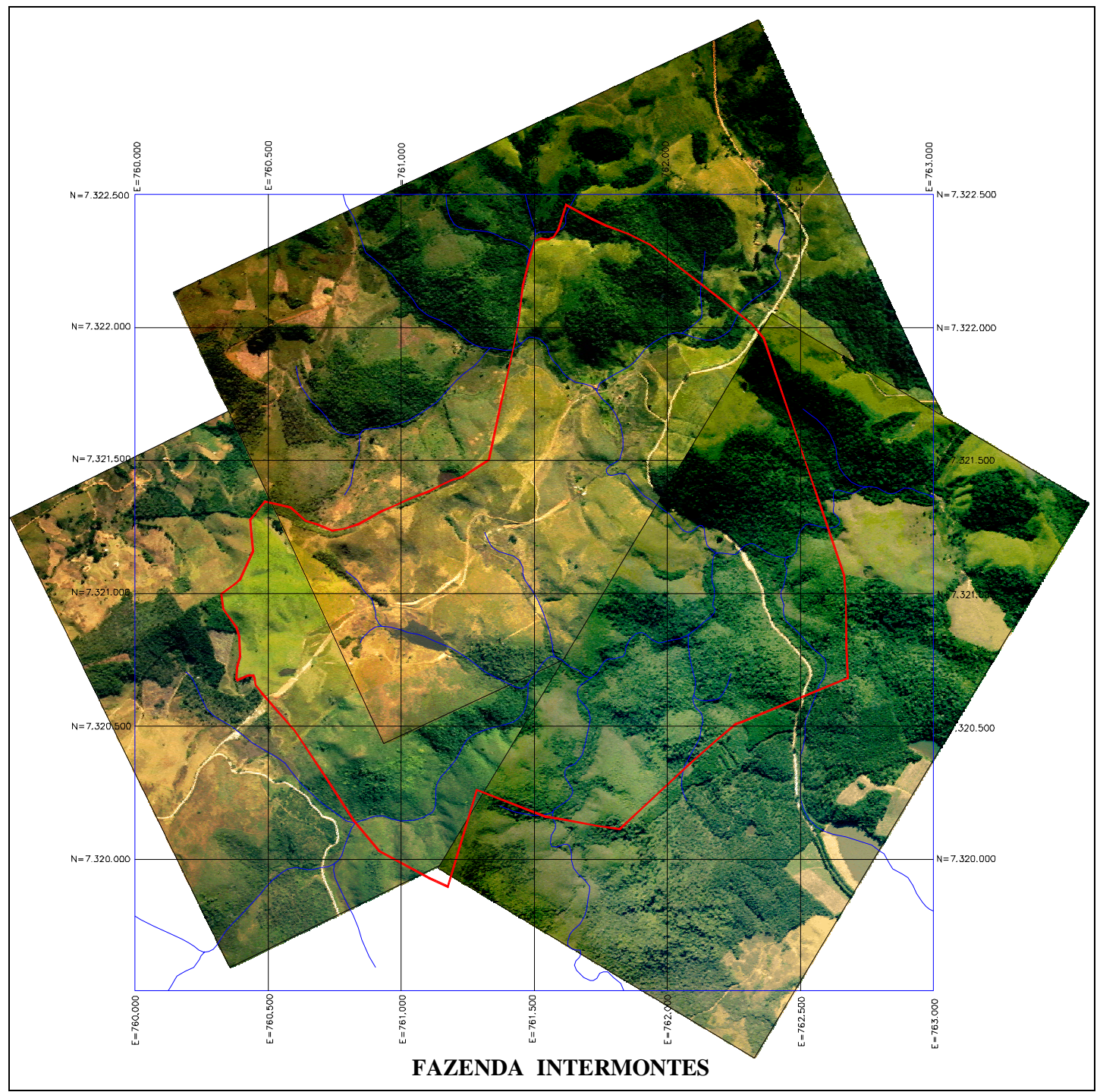

Figura 2 - Montagem do mosaico fotográfico compondo a Fazenda Intermontes (CCRG), município de Ribeirão Grande, SP. Fotografias tiradas no ano de 1999, em escala original 1: 10.000. Limites da propriedade em vermelho

A fotointerpretação foi realizada através da sobreposição das fotografias aéreas digitalizadas com os mapas das propriedades, utilizando o programa AutoCAD ${ }^{\circledR} 2000 \mathrm{e}$ permitindo que situações visualizadas nas fotografias aéreas, como fragmentos florestais, pastos em uso, pastos abandonados, represa, e outras situações, fossem repassadas para o mapa da propriedade. 
Após a fotointerpretação foi realizada a checagem de campo em toda a propriedade, visando nesse momento garantir a confirmação das situações ambientais identificadas na fotointerpretação e um detalhamento mais acurado dessas situações. A checagem também foi realizada para corrigir eventuais falhas ocorridas durante a análise das fotografias aéreas devido a alterações de uso do solo, detalhes não percebidos nas fotografias como indicadores de campo (indivíduos regenerantes) ou mesmo erros de interpretação no momento da análise da foto (Rodrigues et al., 2003a, 2003b, 2003c; Lopes et al., 2004; Rodrigues et al., 2004b).

A última etapa do Zoneamento Ambiental foi à elaboração do mapa com situações de restauração florestal da propriedade. Nesta etapa, todas informações e detalhamentos obtidos pela fotointerpretação e checagem de campo foram repassados ao mapa da propriedade.

A elaboração desse mapa, antes de qualquer atividade de restauração na Fazenda Intermontes, estabeleceu o ponto de partida (Tempo Zero) para o monitoramento da evolução da paisagem.

O monitoramento da evolução da paisagem foi realizado através da edição anual do mapa da propriedade, contendo a evolução das situações ambientais destinadas à restauração. Dessa forma, os mapas produzidos representam a paisagem da Fazenda Intermontes nos anos agrícolas de 2001/2002, 2002/2003, 2003/2004 e 2004/2005. Essas edições dos mapas nos três últimos anos foram realizadas exclusivamente através da checagem de campo, uma vez que não foi possível obter fotografias aéreas da propriedade nestes anos. Assim, as mudanças que ocorreram na paisagem devido às atividades de restauração ou mesmo pela regeneração natural, foram registradas ano a ano, permitindo a sua caracterização e quantificação.

As atualizações dos mapas foi realizada utilizando o programa AutoCad ${ }^{\circledR}$ 2000, possibilitando a quantificação das situações em restauração. 
7.2.4 Situações Ambientais e definição das atividades de restauração da Fazenda Intermontes

Com a definição de um mapa de uso e ocupação do solo antes das intervenções antrópicas (Tempo Zero), a Fazenda Intermontes teve suas áreas divididas em 6 principais situações que foram submetidas às atividades de restauração (Capítulo 3):

g) Pasto sem regeneração natural: pasto formado por Brachiaria decumbens Stapf sem a presença de indivíduos de espécies arbustivo-arbóreas nativos regenerantes;

h) Pasto com regeneração arbustiva: pasto formado por Brachiaria decumbens Stapf, com a presença de indivíduos arbustivos regenerantes em densidade maior que 2000 ind./ha;

i) Pasto com regeneração arbórea: pasto formado por Brachiaria decumbens Stapf com a presença de indivíduos de espécies arbustivo-arbóreas nativos regenerantes em densidade maior que 400 ind./ha;

j) Capoeira: área em processo de regeneração natural, apresentando fisionomia predominantemente florestal de baixo porte $(2$ a $6 \mathrm{~m}$ de altura) e poucas espécies arbóreas, geralmente dos estágios iniciais da sucessão. No geral, os indivíduos regenerantes apresentam baixo diâmetro no tronco. São situações provavelmente oriundas de pastos abandonados, onde houve corte raso, mas atualmente com baixa infestação de Brachiaria decumbens Stapf;

k) Floresta: Florestas naturais onde houve a exploração seletiva de madeiras nobres e provavelmente de palmiteiro, sem ter tido corte raso. Apresentam uma boa diversidade de espécies e formas de vida como epífitas, herbáceas e lianas. Possui um porte variado de 12 a 20 metros de altura, dependendo do grau de conservação;

1) Solo sem vegetação: solo sem cobertura vegetal oriundo da deposição de subsolo em taludes da Fazenda ou de cortes no relevo para abertura de estradas. 
A Figura 3 mostra estas seis situações ambientais na Fazenda Intermontes.

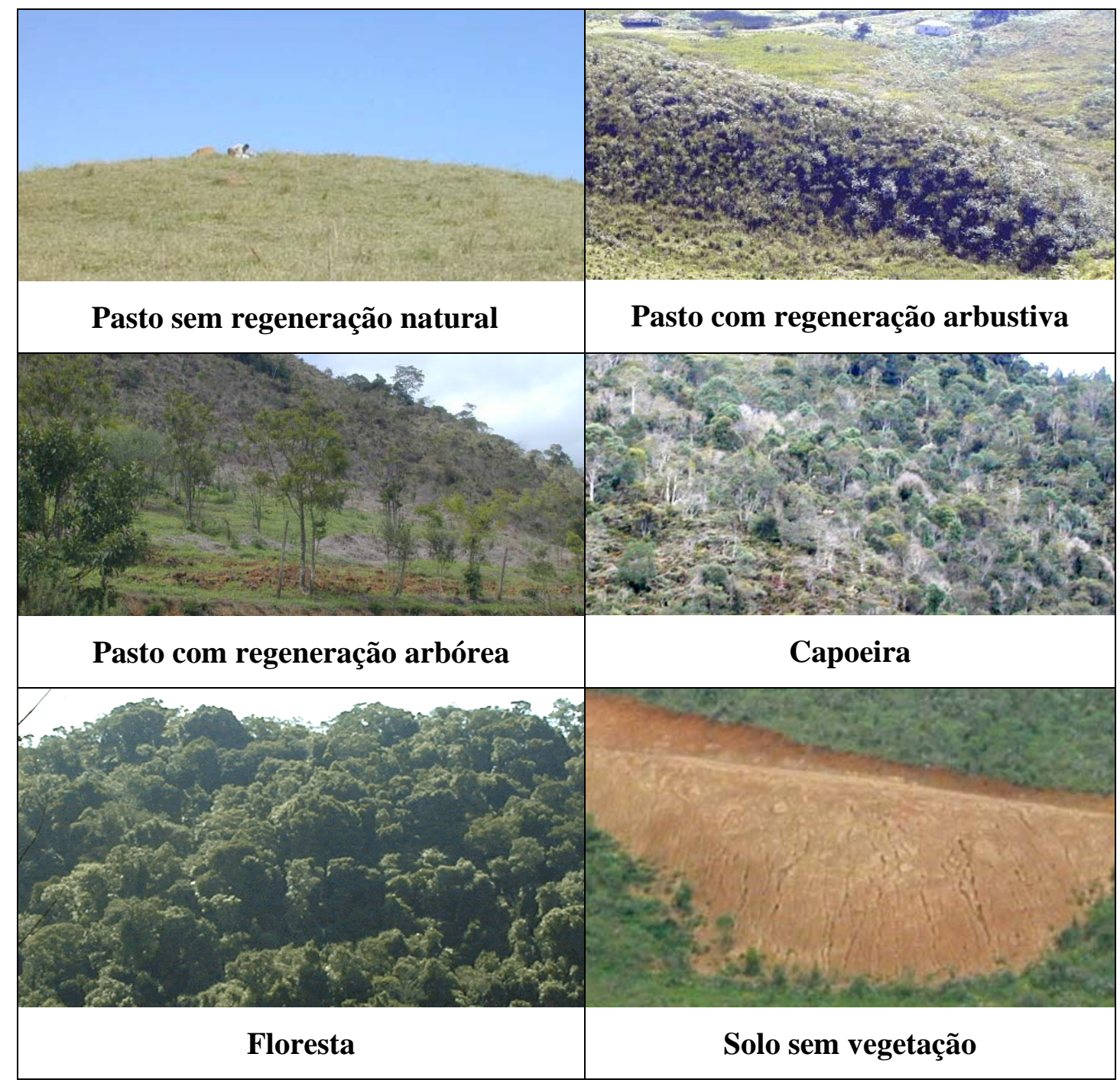

Figura 3 - Situações ambientais encontradas na Fazenda Intermontes - CCRG, município de Ribeirão Grande, São Paulo

Os dados obtidos no Capítulo 3 sobre o banco de sementes autóctone e a cobertura do solo das situações de restauração da Fazenda Intermontes permitiram definir propostas diferenciadas de restauração para cada uma das situações identificadas (Tabela 2). A forma como foram definidas as metodologias de restauração também são detalhadas no Capítulo 3. 
Tabela 2. Definição das metodologias de restauração na Fazenda Intermontes em função da presença de banco de sementes nativas e cobertura do solo

\begin{tabular}{|c|c|c|c|}
\hline $\begin{array}{l}\text { Situação de } \\
\text { Restauração }\end{array}$ & $\begin{array}{c}\text { Regeneração do } \\
\text { banco de sementes } \\
\text { autóctone } \\
\end{array}$ & $\begin{array}{c}\text { Mato- } \\
\text { competição }\end{array}$ & $\begin{array}{c}\text { Metodologia de } \\
\text { restauração, visando o } \\
\text { resgate da biodiversidade }\end{array}$ \\
\hline $\begin{array}{l}\text { Solo sem } \\
\text { vegetação }\end{array}$ & Sem regeneração & Não & $\begin{array}{l}\text { Transferência de banco de } \\
\text { sementes alóctone ou implantação } \\
\text { total }\left(1.667^{*} \text { ind./ha }\right)\end{array}$ \\
\hline $\begin{array}{l}\text { Pasto sem } \\
\text { regeneração } \\
\text { natural }\end{array}$ & Sem regeneração & Alta & $\begin{array}{l}\text { Implantação total }(1.667 * \text { ind./ha) } \\
\text { e controle de competidores }\end{array}$ \\
\hline $\begin{array}{l}\text { Pasto c/ } \\
\text { regeneração } \\
\text { arbustiva }\end{array}$ & Baixo & Alta & $\begin{array}{l}\text { Indução do banco autóctone } \\
\text { através de revolvimento do solo, } \\
\text { implantação total (1.667* ind./ha) } \\
\text { e controle de competidores }\end{array}$ \\
\hline $\begin{array}{l}\text { Pasto c/ } \\
\text { regeneração } \\
\text { arbórea }\end{array}$ & Médio & Alta & $\begin{array}{l}\text { Indução do banco através de } \\
\text { revolvimento do solo, condução da } \\
\text { regeneração natural, controle de } \\
\text { competidores, adensamento e } \\
\text { enriquecimento }\end{array}$ \\
\hline Capoeira & Alto & Baixa & $\begin{array}{l}\text { Indução do banco, condução da } \\
\text { regeneração natural e } \\
\text { enriquecimento }\end{array}$ \\
\hline Floresta & Alto & Não & $\begin{array}{l}\text { Possível enriquecimento } \\
\text { (facultativo) }\end{array}$ \\
\hline
\end{tabular}

A descrição detalhada das metodologias de restauração utilizadas na Fazenda Intermontes pode ser obtida no projeto de restauração da Fazenda Intermontes ou nos trabalhos de Lopes et al., (2004) e Rodrigues et al., (2004b).

Vale ressaltar que essas metodologias vem sendo implantadas de forma contínua ao longo dos anos. Isso permitiu uma análise do potencial de auto-recuperação e da evolução das situações ambientais, tanto nas áreas onde houve intervenção com atividades de restauração, quanto nas áreas que simplesmente foram abandonadas, sendo apenas retirado os fatores de degradação que atuavam sobre elas. 


\subsection{Resultados e Discussão}

As Figuras 4, 5, 6 e 7 mostram os mapas com as situações ambientais encontradas na Fazenda Intermontes nos anos agrícolas de 2001/2002, 2002/2003, $2003 / 2004$ e 2004/2005.

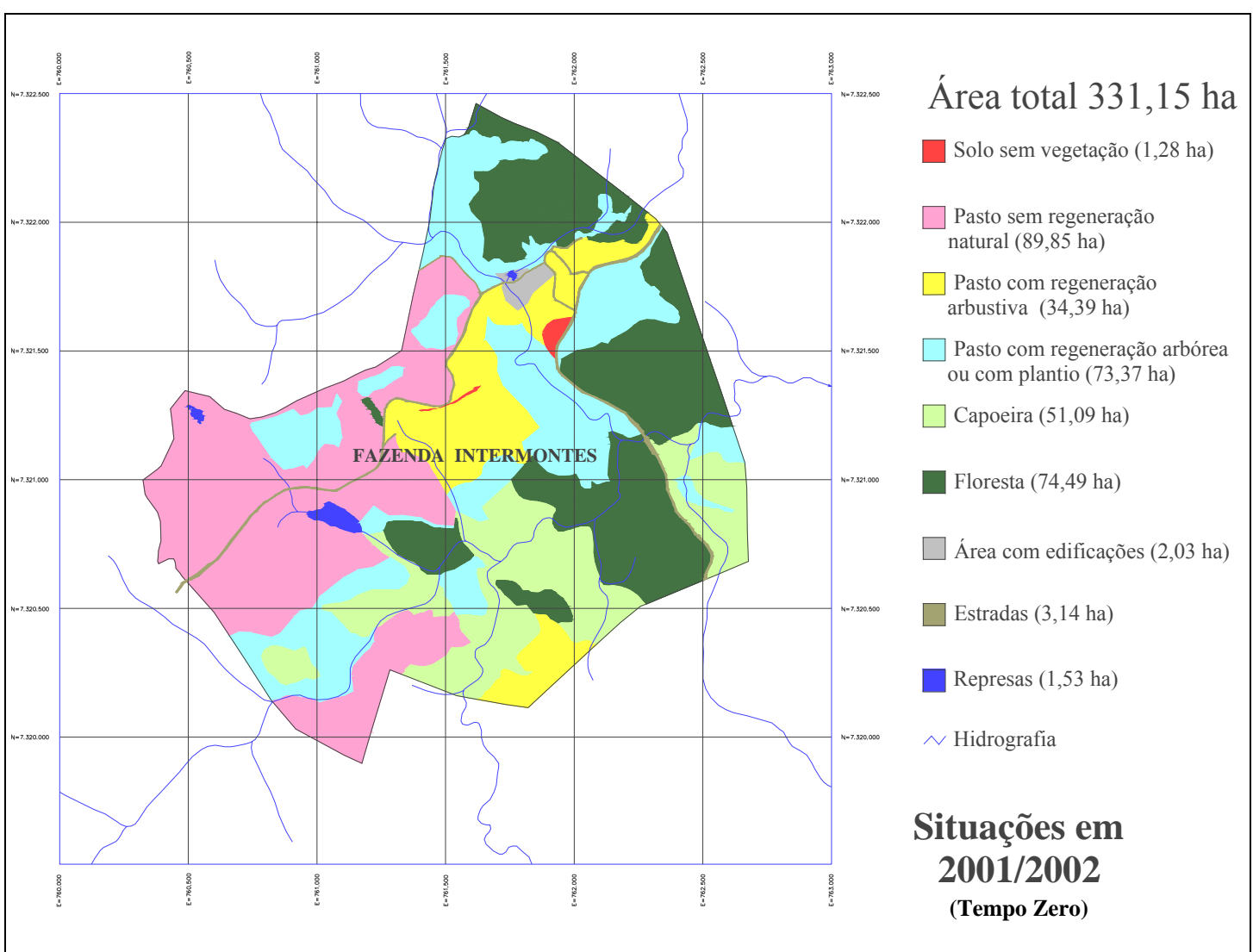

Figura 4 - Principais situações ambientais de restauração encontradas na Fazenda Intermontes no ano agrícola de 2001/2002 (Tempo Zero), CCRG, município de Ribeirão Grande, São Paulo 


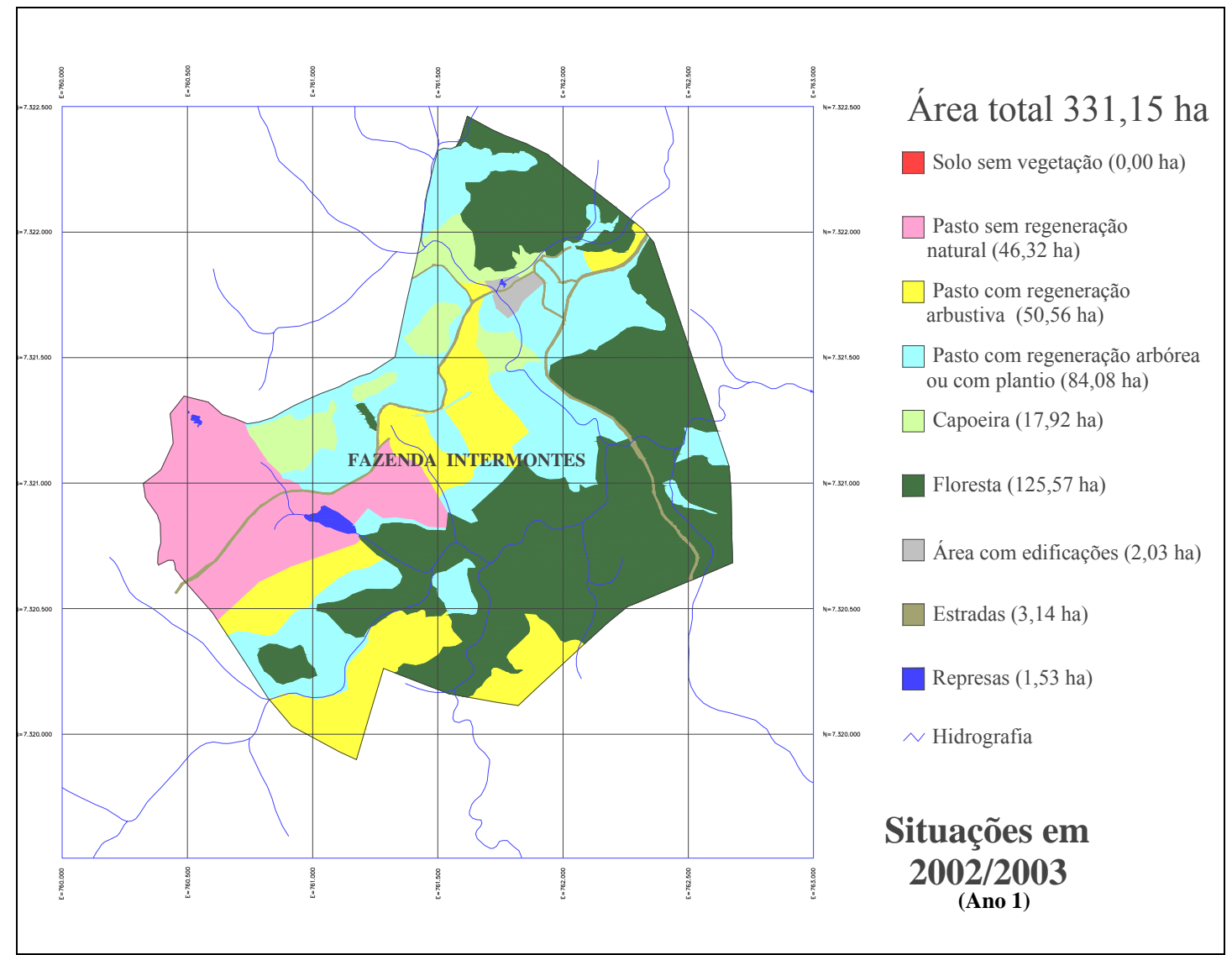

Figura 5 - Principais situações ambientais de restauração encontradas na Fazenda Intermontes no ano agrícola de 2002/2003 (Ano 1), CCRG, município de Ribeirão Grande, São Paulo 


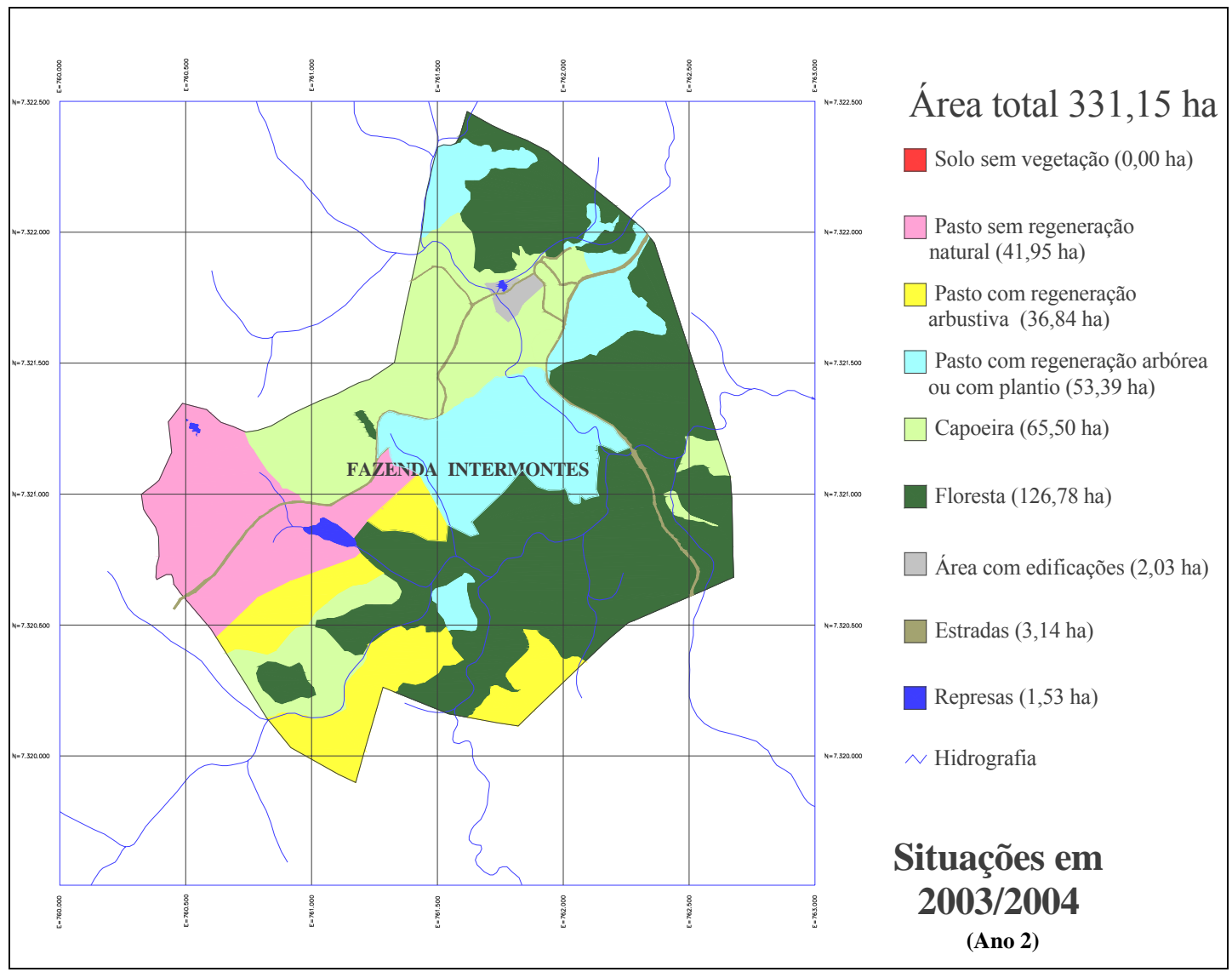

Figura 6 - Principais situações ambientais de restauração encontradas na Fazenda Intermontes no ano agrícola de 2003/2004 (Ano 2), CCRG, município de Ribeirão Grande, São Paulo 


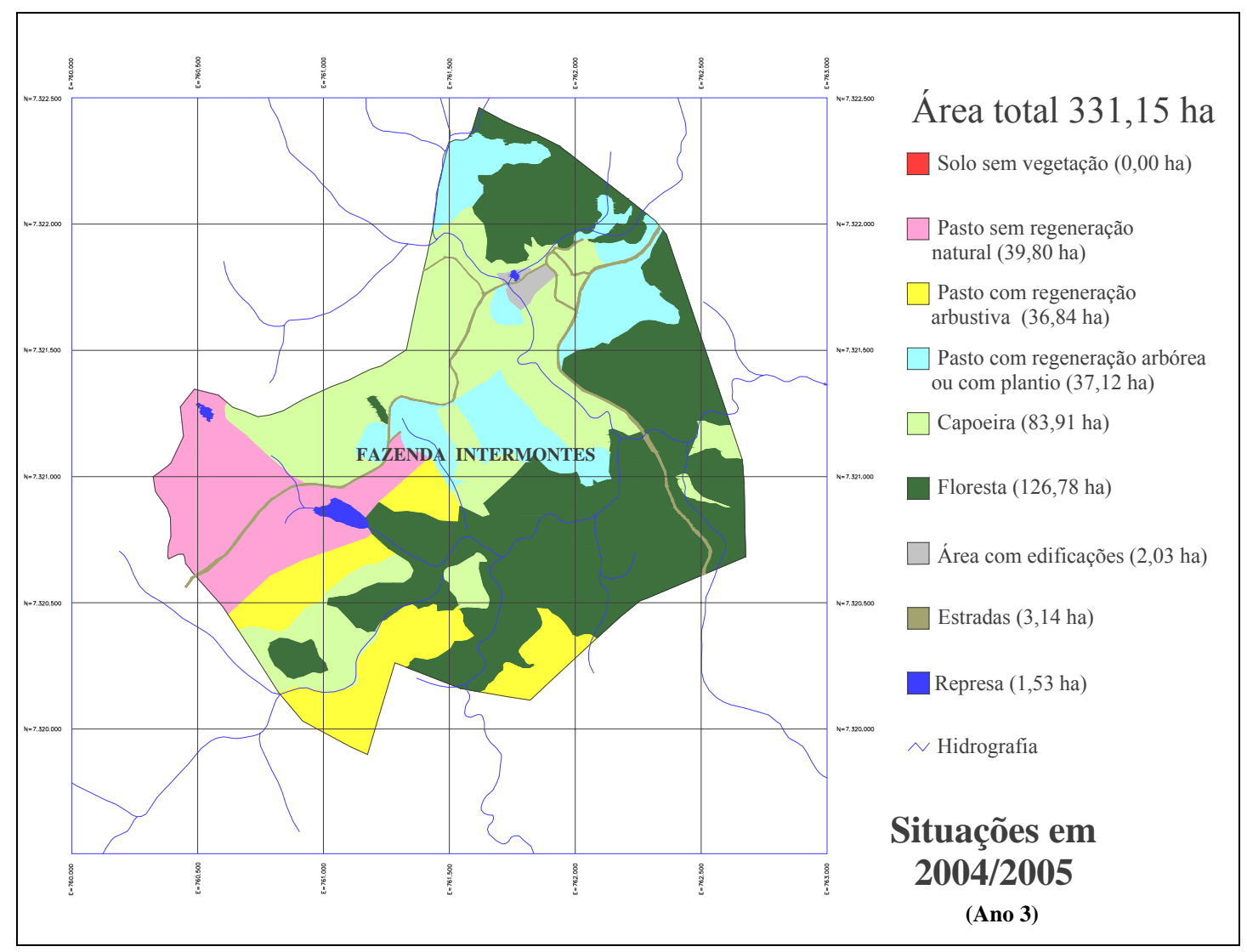

Figura 7 - Principais situações ambientais de restauração encontradas na Fazenda Intermontes no ano agrícola de 2004/2005 (Ano 3), CCRG, município de Ribeirão Grande, São Paulo

A série temporal apresentada (Figuras 4, 5, 6 e 7) mostra a localização e a evolução no tempo de todas as situações ambientais definidas no "Tempo Zero", desde o ano de 2001/2002 até 2004/2005. Nessa seqüência é interessante notar a formação gradual de um grande corredor ecológico unindo na paisagem local, os fragmentos remanescentes mais conservados. A posição das áreas que estão sendo atualmente restauradas também revela que daqui alguns anos será formado um grande bloco florestal com aproximadamente 290 hectares. A formação de corredores ecológicos e de blocos florestais é estratégica para o fluxo de animais dispersores e polinizadores, permitindo maior fluxo gênico entre as populações e aumentando a quantidade de 
recursos alimentícios para fauna (Noss, 1987; Macedo, 1993b; Proctor \& Lack, 1996; Kageyama \& Gandara, 2004).

A mudança de situações com alto nível de degradação para situações mais complexas como capoeira e florestas, revela o avanço sucessional das áreas em restauração. Entretanto, essas mudanças na fisionomia não estão, necessariamente, relacionadas com a eficiência das metodologias de restauração aplicadas (Souza \& Batista, 2004). A inexistência de diversidade ou a presença de fatores de degradação podem retardar o até mesmo retroceder o avanço sucessional.

A Tabela 2 apresenta os valores em área de cada situação ambiental ao longo dos anos na Fazenda Intermontes.

Tabela 2. Valores em área (ha) e porcentagens de cada situação ambiental ao longo dos anos na Fazenda Intermontes, CCRG, município de Ribeirão Grande, SP

\begin{tabular}{|c|c|c|c|c|c|c|c|c|}
\hline \multirow[b]{2}{*}{$\begin{array}{c}\text { Situação de } \\
\text { Restauração }\end{array}$} & \multicolumn{8}{|c|}{ Ano agrícola (ha) } \\
\hline & $\begin{array}{c}2001 / 2002 \\
\text { (ha) }\end{array}$ & $\%$ & $\begin{array}{c}2002 / 2003 \\
\text { (ha) }\end{array}$ & $\%$ & $\begin{array}{c}2003 / 2004 \\
\text { (ha) }\end{array}$ & $\%$ & $\begin{array}{c}2004 / 2005 \\
\text { (ha) }\end{array}$ & $\%$ \\
\hline $\begin{array}{l}\text { Solo sem } \\
\text { vegetação }\end{array}$ & 1,28 & $(0,4)$ & 0,00 & $(0,0)$ & 0,00 & $(0,0)$ & 0,00 & $(0,0)$ \\
\hline $\begin{array}{l}\text { Pasto sem } \\
\text { regeneração } \\
\text { Natural }\end{array}$ & 89,85 & $(27,1)$ & 46,32 & $(14,0)$ & 41,95 & $(12,7)$ & 39,80 & $(12,0)$ \\
\hline $\begin{array}{l}\text { Pasto c/ } \\
\text { regeneração } \\
\text { arbustiva }\end{array}$ & 34,39 & $(10,4)$ & 50,56 & $(15,3)$ & 36,84 & $(11,1)$ & 36,84 & $(11,1)$ \\
\hline $\begin{array}{l}\text { Pasto c/ } \\
\text { regeneração } \\
\text { arbórea ou com } \\
\text { plantio florestal }\end{array}$ & 73,37 & $(22,2)$ & 84,08 & $(25,4)$ & 53,39 & $(16,1)$ & 37,12 & $(11,2)$ \\
\hline Capoeira & 51,09 & $(15,4)$ & 17,92 & $(5,4)$ & 65,50 & $(19,8)$ & 83,91 & $(25,3)$ \\
\hline Floresta & 74,49 & $(22,5)$ & 125,57 & $(37,9)$ & 126,78 & $(38,3)$ & 126,78 & $(38,3)$ \\
\hline $\begin{array}{l}\text { Outras } \\
\text { situações (sede, } \\
\text { lagos, etc.) }\end{array}$ & 6,70 & $(2,0)$ & 6,70 & $(2,0)$ & 6,70 & $(2,0)$ & 6,70 & $(2,0)$ \\
\hline Total & 331,2 & $(100)$ & 331,2 & $(100)$ & 331,2 & $(100)$ & 331,2 & $(100)$ \\
\hline
\end{tabular}

Os valores apresentados na Tabela 2 mostram a evolução em área (ha) das situações da paisagem submetidas a diferentes ações de restauração. As situações de 
floresta e capoeira se destacam em termos de crescimento de área ocupada nos quatro anos de análise, sendo $70,2 \%$ e $64 \%$ de aumento, respectivamente.

A maior parte do aumento da situação de floresta foi devido ao isolamento, de algumas áreas, dos fatores de degradação, já que muito provavelmente essas áreas eram usadas, num passado recente (últimos 15 anos) e antes da propriedade ser adquirida pela CCRG em 2000, como áreas de pastagem na Fazenda. Vale ressaltar que essas áreas foram classificadas como capoeiras em 2001, já no início do projeto de restauração. Esses locais foram favorecidos geograficamente e topograficamente na Fazenda, por se encontrar em situações de difícil acesso e, portanto, mais protegidas de ações antrópicas e no entorno de fragmentos florestais relativamente bem conservados. Esse isolamento natural, proporcionado pela aquisição da área pela empresa e sua destinação para restauração, protegeram durante anos essas áreas dos fatores de degradação como pastoreio, extrativismo seletivo e fogo, transformando rapidamente a fisionomia de capoeira em floresta.

O segundo maior aumento em área foi da situação de capoeira, tendo duas principais causas. A primeira foi resultado da evolução das áreas de pasto com regeneração arbórea para capoeira, em função do isolamento dessas áreas dos fatores de degradação. Vale ressaltar que, entre essas áreas de pasto com regeneração arbórea que evoluíram, algumas eram áreas mais isoladas de fragmentos florestais na paisagem, mais que tiveram um uso histórico menos intensivo pelo homem. Isso ocorreu devido suas dificuldades de acesso e mecanização pela topografia acidentada, possibilitando assim, sua efetiva recuperação num curto espaço de tempo. Entretanto, o elevado potencial de auto-recuperação dessas áreas, foi definido não pela possibilidade de chegada de propágulos do entorno, mas pela presença de propágulos remanescentes, que se mantiveram no local pelo uso de baixa tecnologia na implantação e manutenção dessa área agrícola. A segunda causa responsável pelo aumento da situação de capoeira foi conseqüência da implantação e do bom desenvolvimento das ações de restauração da área de pasto sem regeneração natural, no ano agrícola de 2001/2002 (Tempo Zero).

As situações de maior degradação, como solo sem vegetação, pasto sem regeneração natural e pasto com regeneração arbórea, tiveram suas áreas iniciais 
bastante reduzidas nos quatro anos, sendo $100 \%, 55,70 \%$ e $49,41 \%$ menores, respectivamente. Isso ocorreu em função das ações de restauração implantdas na Fazenda Intermontes nesses quatro anos e da potencialização dos processos de regeneração natural nessas áreas, quando devidamente manejadas.

A situação de pasto com regeneração arbustiva, apesar de receber intervenções de restauração, não teve grandes alterações em sua área, nesses 4 anos, ocorrendo apenas mudanças espaciais na Fazenda. Isso ocorreu devido ao incremento dessa situação por meio do avanço sucessional de trechos de áreas de pasto sem regeneração que passaram para pasto com regeneração arbustiva. Ao mesmo tempo e em proporções semelhantes, houve a passagem da situação de pasto com regeneração arbustiva para uma condição de área com plantio florestal.

As seqüências das Figuras 8 a 27 apresentam e ilustram as intervenções de restauração para cada uma das situações ou unidades da paisagem e as alterações (evolução) dessas unidades na Fazenda Intermontes nos anos agrícolas de 2001/2002, 2002/2003, 2003/2004 e 2004/2005.

A Figura 8 se refere à situação de "solo sem vegetação" que inclui os taludes e as áreas de corte e aterro que foram resultantes da abertura de estradas no interior da propriedade, algumas delas já abandonadas. 


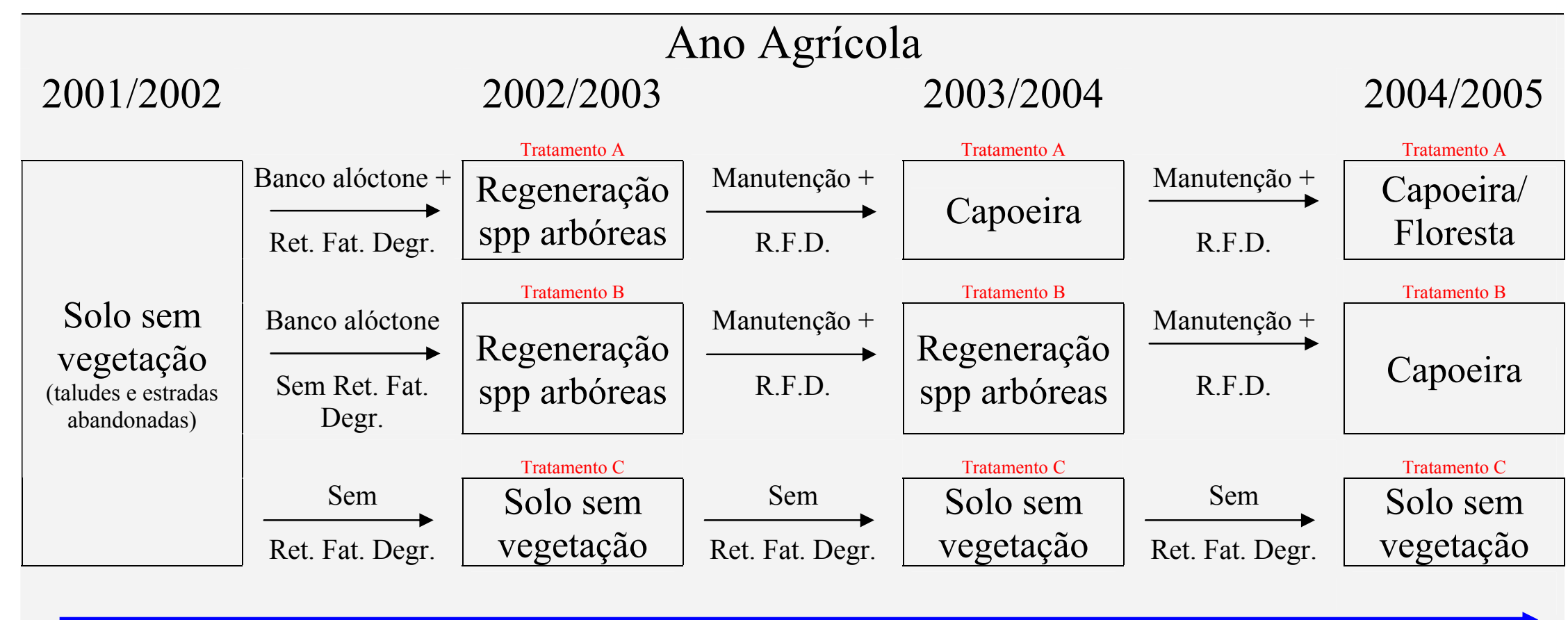

DIVERSIDADE

$+$

Figura 8 - Fluxograma com os anos agrícolas e a evolução da situação de solo sem vegetação (taludes e estradas abandonadas) em função das ações de restauração. Fazenda Intermontes, CCRG, Município de Ribeirão Grande, SP. Ret. Fat. Degr.= retirada dos fatores de degradação 
Nessa situação de "solo sem vegetação", em função da sua posição na paisagem local e das dificuldades de contenção do escorrimento superficial de águas pluviais, acabaram recebendo três tratamentos: Tratamento A) Retirada de fatores de degradação no primeiro ano, mais cobertura com banco de sementes alóctone no primeiro ano, mais adubação verde e manutenção anual, que nesta situação, constituiu apenas de adubações mensais de cobertura em área total; Tratamento B) Retirada de fatores de degradação apenas no segundo ano, mais cobertura com banco de sementes alóctone no primeiro ano, mais adubação verde e manutenção; Tratamento C) Sem retirada de fatores de degradação e sem cobertura com banco de sementes ou adubação verde.

As Figuras 9, 10 e 11 apresentam a seqüência temporal da recuperação de duas áreas com solos sem vegetação (estrada e taludes das estradas).

O tratamento A apresentou a evolução mais rápida que os demais tratamentos, passando logo no primeiro ano para uma área com regeneração arbórea, no segundo para a situação de capoeira. No terceiro ano, a área do tratamento $\mathbf{A}$ apresentava características florestais com dossel inteiramente fechado, pelos menos dois estratos bem definidos e com várias formas de vida instaladas no local como arvoretes, arbustos, herbáceas e lianas não agressivas (Figuras 12 e 13), sendo considerada uma situação de transição de capoeira para floresta.

Vale ressaltar que a situação inicial de solo sem vegetação foi considerada a situação de maior degradação entre todas as outras encontradas na Fazenda e, embora ela tivesse essa característica, foi a que apresentou o melhor resultado em termos de restauração, uma vez que, nenhuma outra situação conseguiu evoluir de forma tão acelerada no período considerado, devido as ações de restauração adotadas.

No tratamento $\mathbf{B}$, a retirada dos fatores de degradação só foi efetivada a partir do segundo ano. Isso fez com que fossem retardados os avanços sucessionais dessa área que atualmente se encontra na situação de capoeira. Embora isso tenha ocorrido, a evolução dessa área, nos últimos anos, aponta para a restauração dos processos ecológicos, aumentando a diversidade e garantindo a formação da floresta. 


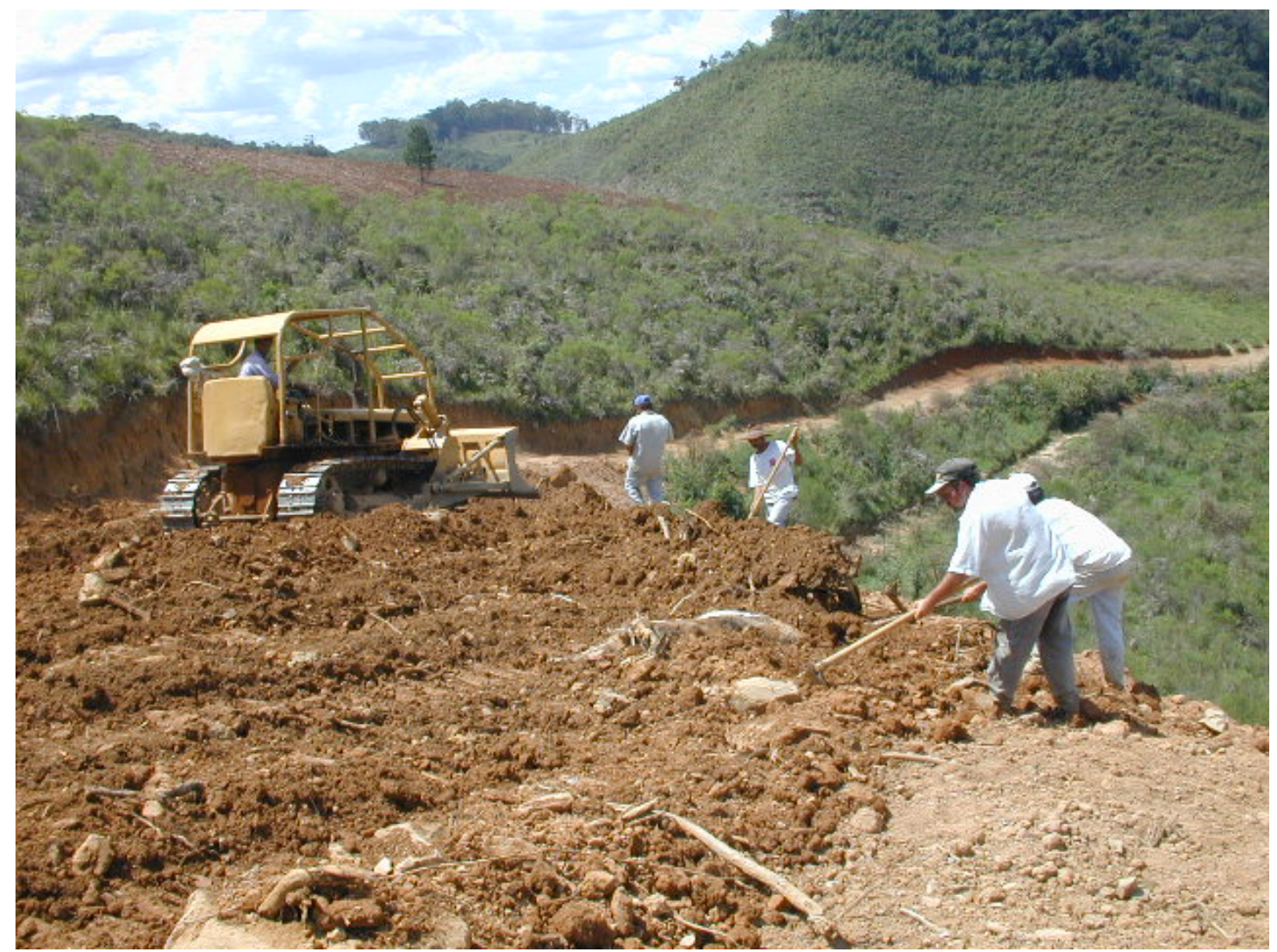

Figura 9 - Depósito de solo contendo banco de sementes alóctone em área de estrada abandonada no interior da Fazenda Intermontes, CCRG, município de Ribeirão Grande, SP 


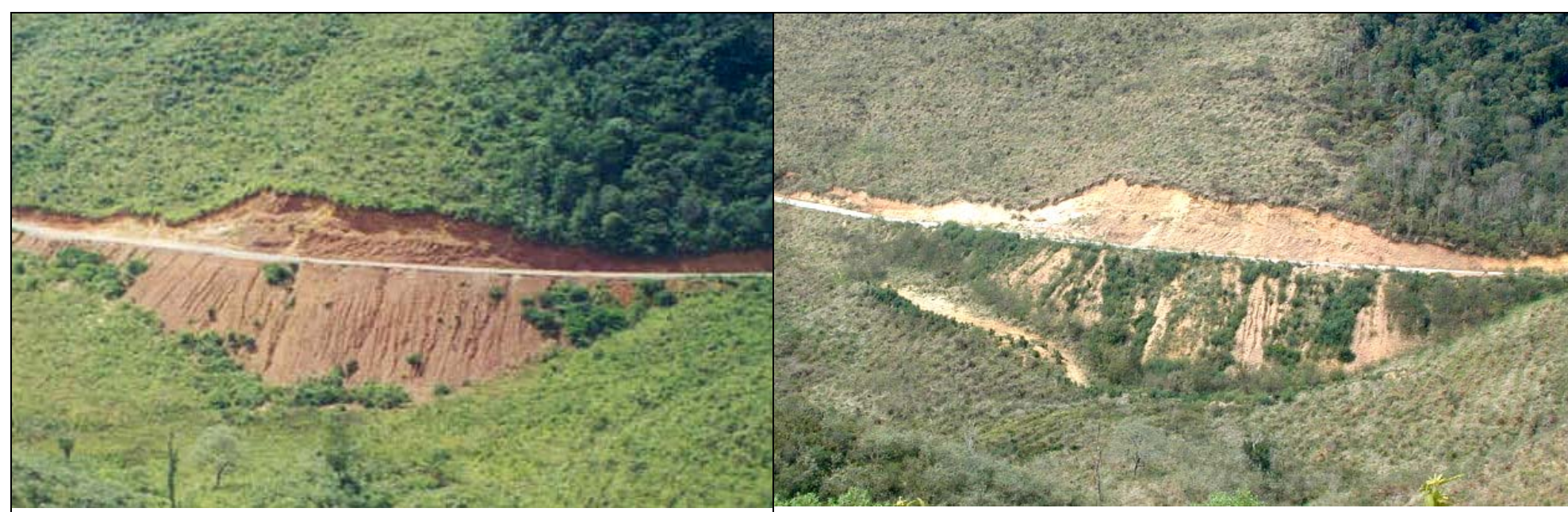

Agosto/2001 - solo sem vegetação

Outubro/2002 - início da cobertura vegetal

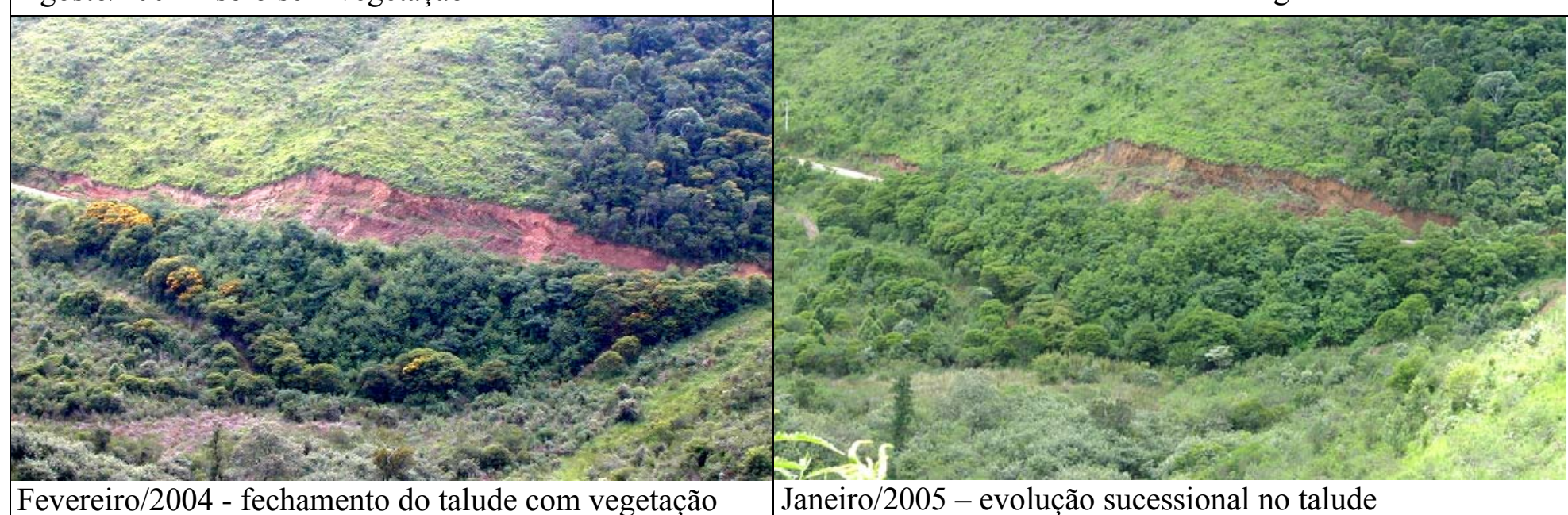

Fevereiro/2004 - fechamento do talude com vegetação

Janeiro/2005 - evolução sucessional no talude

Figura 10 - Area de talude da estrada municipal (solo sem vegetação) recuperada com banco de sementes alóctone: seqüência temporal. Fazenda Intermontes, município de Ribeirão Grande, SP 

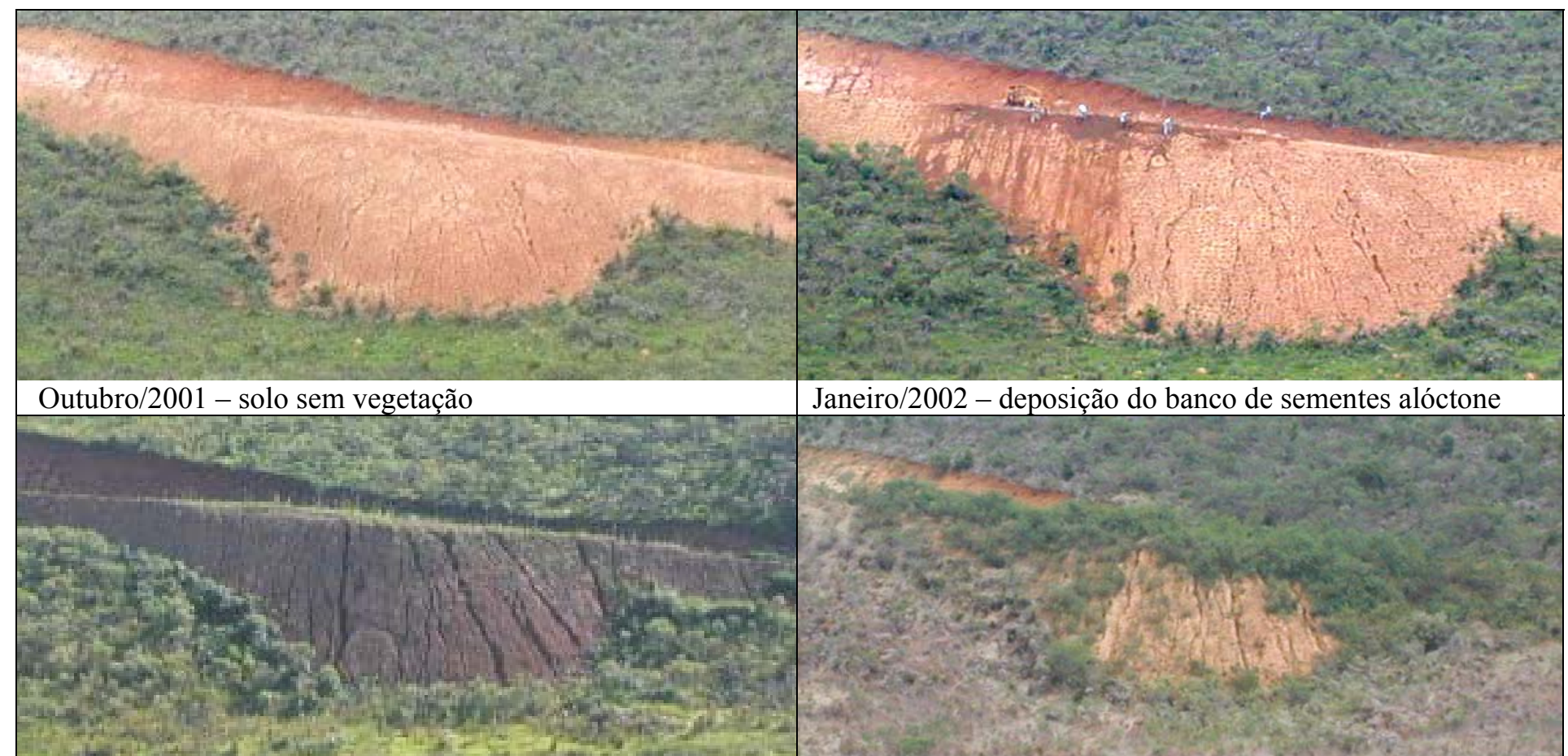

Janeiro/2002 - deposição do banco de sementes alóctone
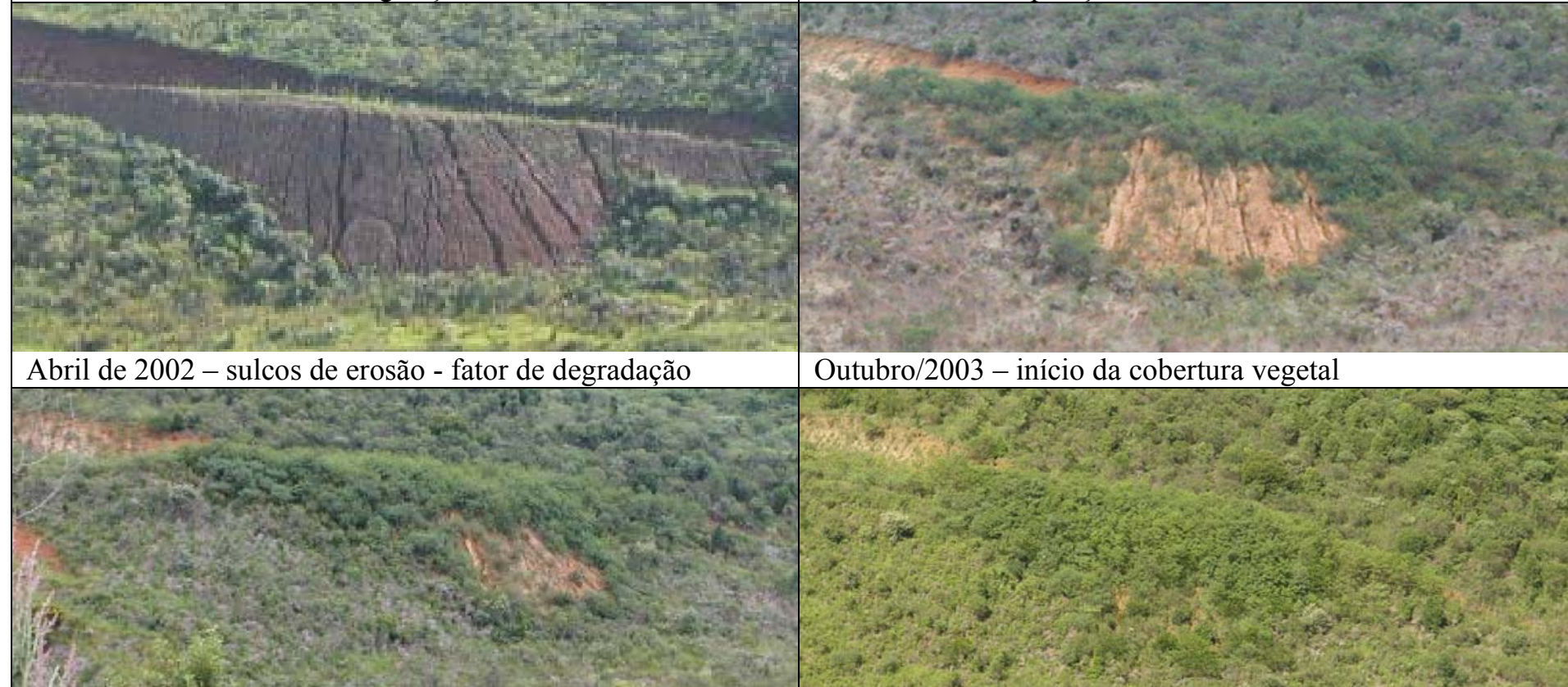

Outubro/2003 - início da cobertura vegetal

Fevereiro/2004 - fechamento parcial do talude com vegetação Janeiro/2005 - fechamento total do talude com vegetação

Figura 11 - Área de talude da estrada interna da fazenda (solo sem vegetação), recuperada com banco de sementes alóctone: seqüência temporal. Fazenda Intermontes, município de Ribeirão Grande, SP 
$\mathrm{Na}$ área do tratamento $\mathbf{C}$, embora houvesse tentativas de contenções das enxurradas oriundas das estradas do entorno, que provocavam sulcos de erosão no local, não foi possível executá-las de forma efetiva, acarretando na não retirada desse fator de degradação. A conseqüência desse fato é a não evolução sucessional desse trecho da situação de solo sem vegetação, que permaneceu a mesma desde o início do projeto.

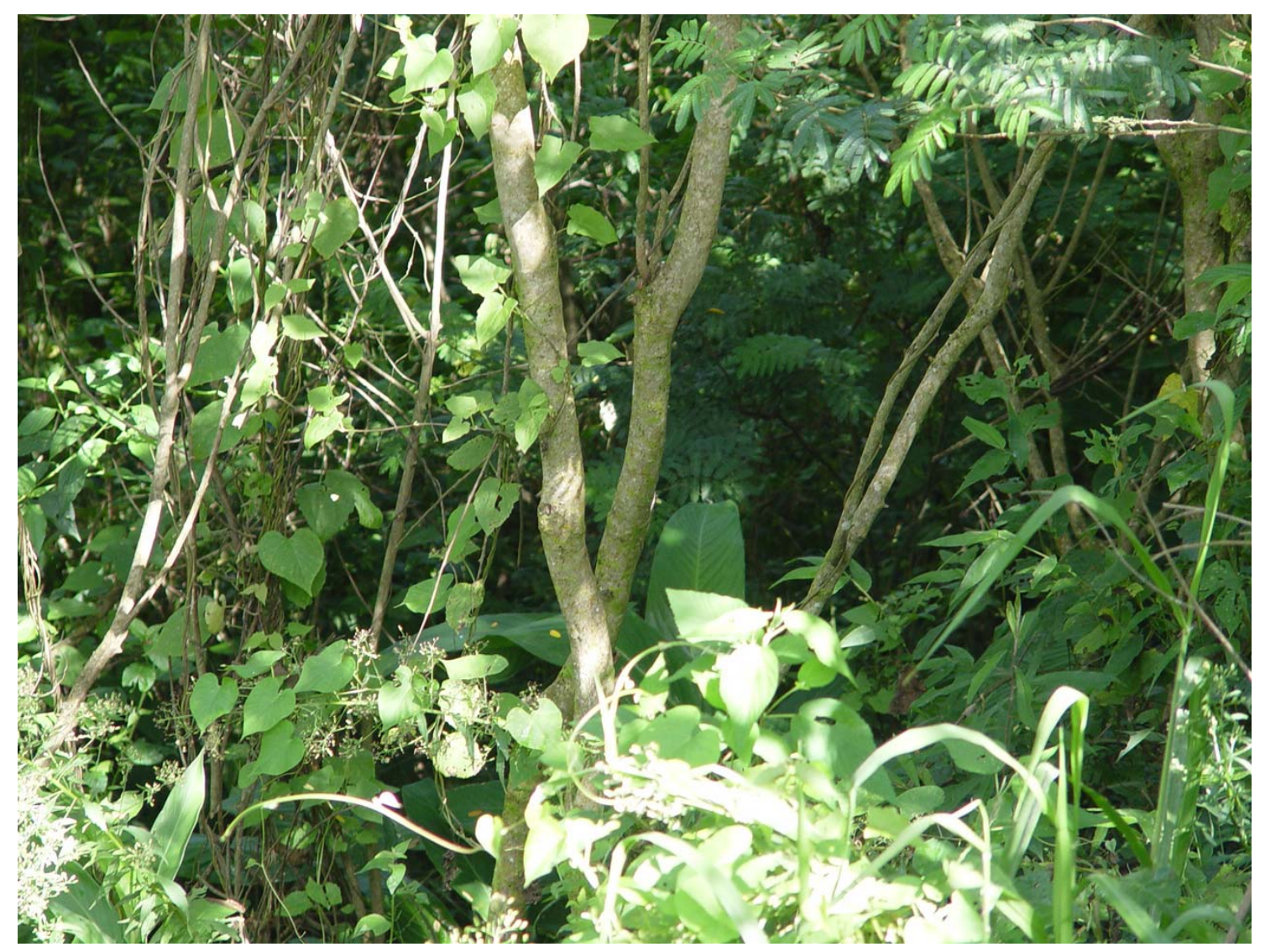

Figura 12 - Antiga área de aterro da estrada municipal (solo sem vegetação) recuperada com banco de sementes alóctone: detalhe para a formação de várias formas de vida (lianas, arbustos e herbáceas). Fazenda Intermontes, município de Ribeirão Grande, SP 


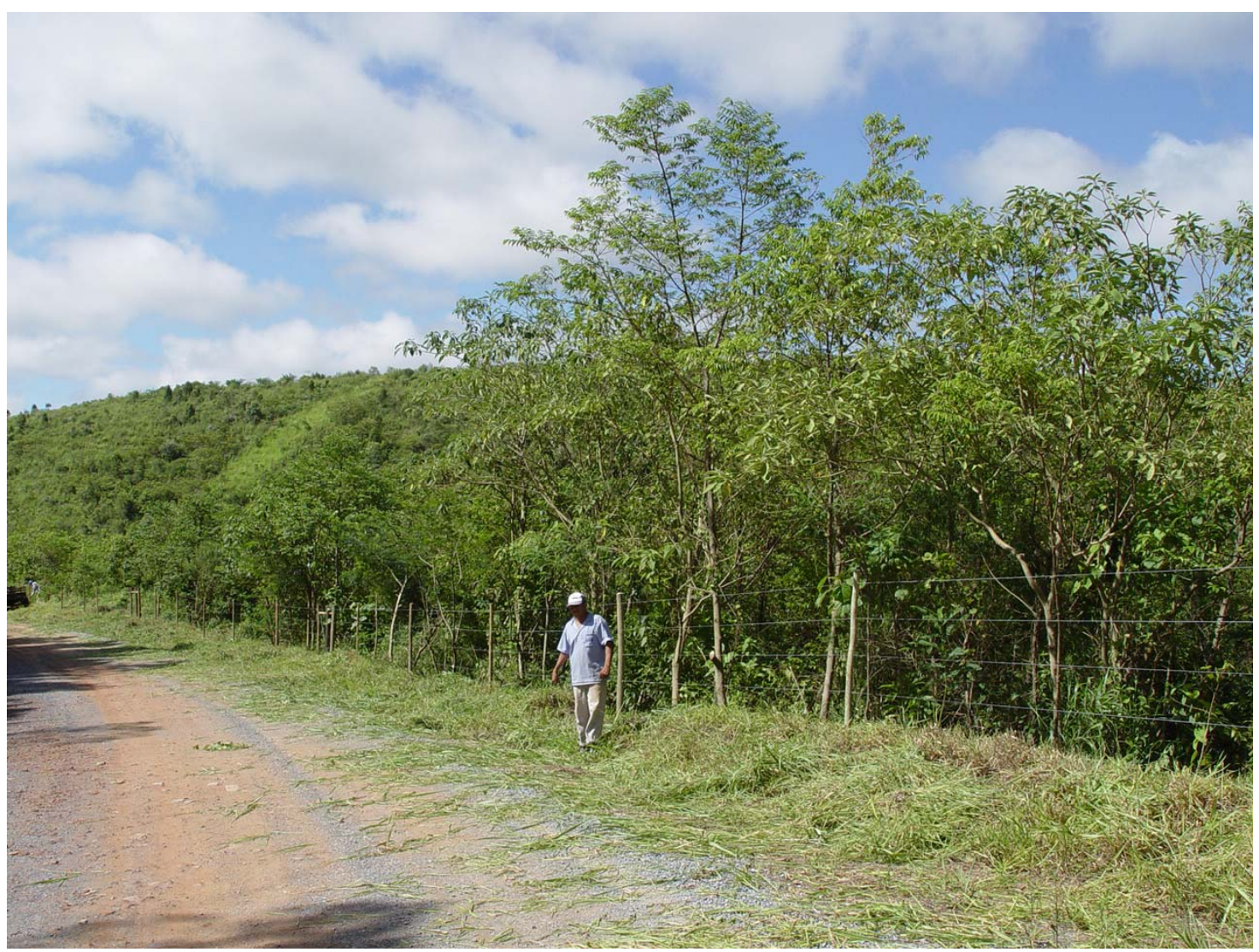

Figura 13 - Antiga área de aterro da estrada municipal (solo sem vegetação) recuperada com banco de sementes alóctone. Fazenda Intermontes, município de Ribeirão Grande, SP

A Figura 14 se refere à situação de "pasto sem regeneração natural". Apesar dessa situação ter sido colocada pelo projeto de adequação ambiental da propriedade como prioritária para restauração com plantio de mudas de espécies arbóreas nativas, em função do baixo potencial de regeneração natural, suas áreas não foram totalmente implantadas devido a sua elevada dimensão e sua localização de difícil acesso, em alguns trechos da propriedade. Dessa forma, essa situação acabou recebendo três tratamentos: Tratamento A) Retirada de fatores de degradação no primeiro ano, sendo o principal deles, o pastoreio por gado bovino. Em seguida foi feito o plantio de indivíduos arbóreos com 1667 ind./ha e manutenção anual, que constituiu de controle de gramíneas (braquiária) e adubações de cobertura no período chuvoso; Tratamento B) Apenas 
retirada de fatores de degradação (pastoreio do gado, fogo, etc.), sem plantio ou manutenção da área; Tratamento C) Sem retirada de fatores de degradação, sendo neste caso, a área mantida regularmente como pastagem.

O Tratamento A apresentou maior avanço sucessional que os demais tratamentos (Figura 15). Isso ocorreu devido ao plantio de mudas arbóreas e a manutenção realizada nessas áreas ao longo de três anos. Nessa situação, o controle das espécies competidoras e as adubações foram fundamentais para a evolução do pasto sem regeneração natural com plantio de mudas para uma situação de capoeira, no final do ano agrícola de 2003/2004, três anos depois.

No tratamento $\mathbf{B}$, só ocorreu a retirada dos fatores de degradação desde o primeiro ano de intervenção. Isso promoveu os avanços sucessionais dessa área que atualmente se encontra na situação de pasto com regeneração arbustiva (Figura 16). A posição topográfica dessas áreas, formadas por vertentes opostas aos fragmentos florestais remanescentes, e a inexistência de poleiros para atração de animais dispersores, desfavoreceram a chegada de propágulos de espécies arbóreas nessas áreas. Isso provavelmente explica a não evolução da situação de pasto com regeneração arbustiva nessas áreas para outras situações sucessionalmente mais complexas. Assim, torna-se possível uma outra intervenção de restauração nessas áreas, promovendo o plantio de espécies arbóreas, principalmente aquelas com grande interação com a fauna, caso não se confirme em ações de monitoramento, avaliando os indivíduos jovens regenerantes, que essas espécies não estão efetivamente colonizando essa área na intensidade que permite uma restauração em médio prazo.

$\mathrm{Na}$ área do tratamento $\mathbf{C}$ não houve a total retirada dos fatores de degradação, que neste caso era a presença de gado. A conseqüência desse fato é a não evolução sucessional da situação de pasto sem regeneração natural, que permaneceu a mesma desde o início do projeto (Figura 17). 


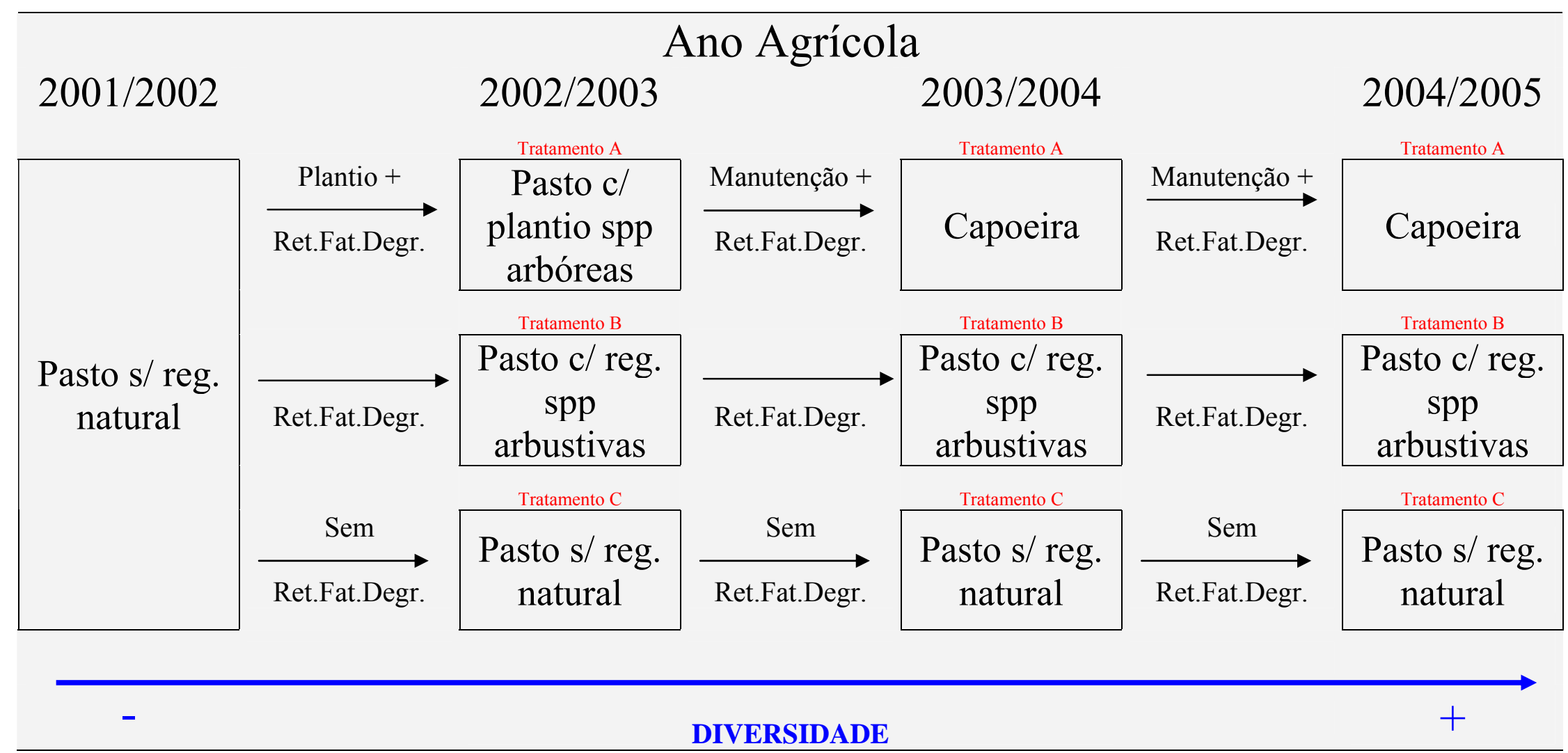

Figura 14 - Fluxograma com os anos agrícolas e a evolução da situação de pasto sem regeneração natural em função das ações de restauração. Fazenda Intermontes, CCRG, Município de Ribeirão Grande, SP. Ret.Fat.Degr. = retirada dos fatores de degradação 


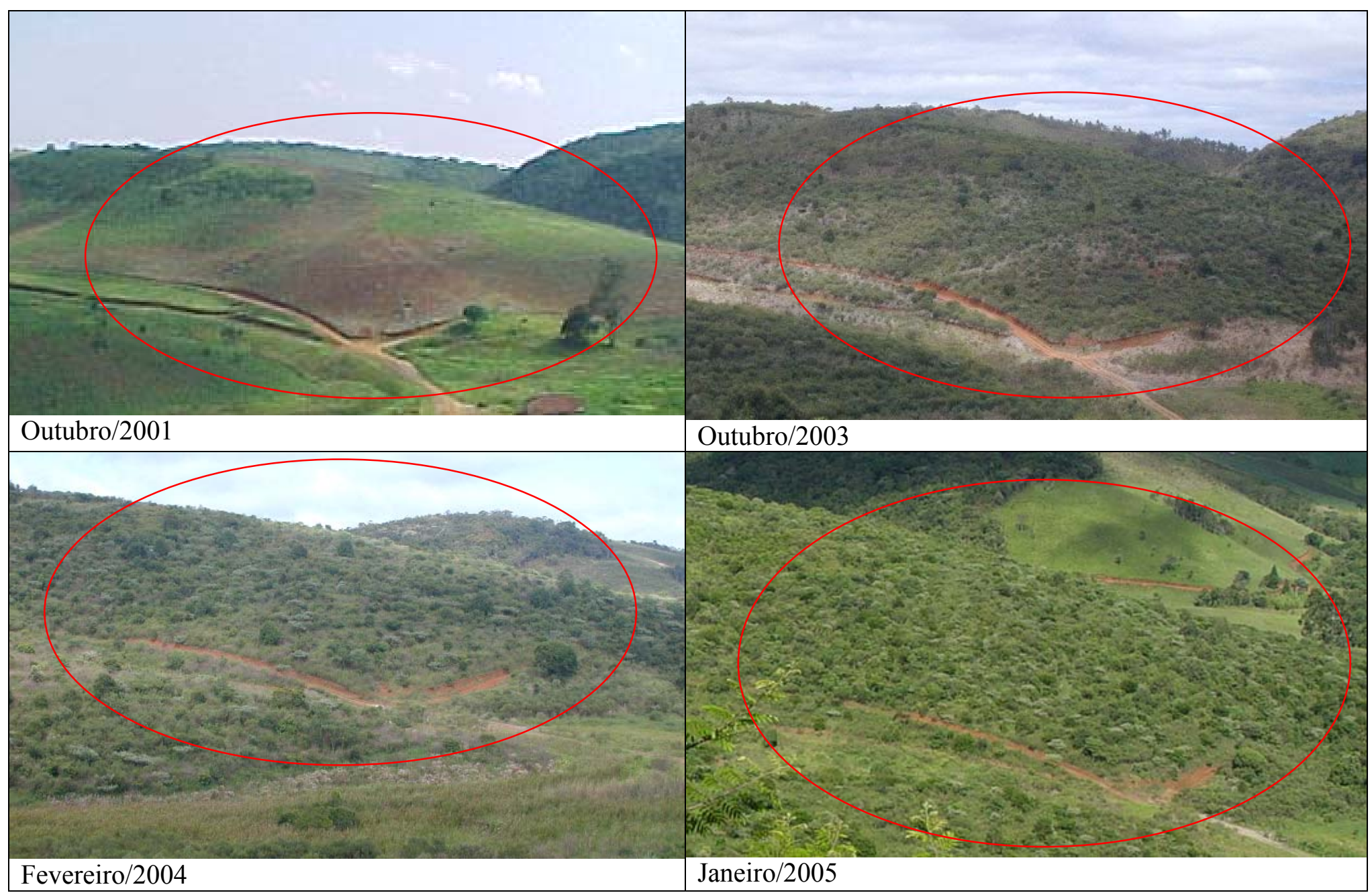

Figura 15 - Sequência temporal da restauração da situação de pasto sem regeneração natural (Tratamento A), Fazenda Intermontes, CCRG, Município de Ribeirão Grande, SP 

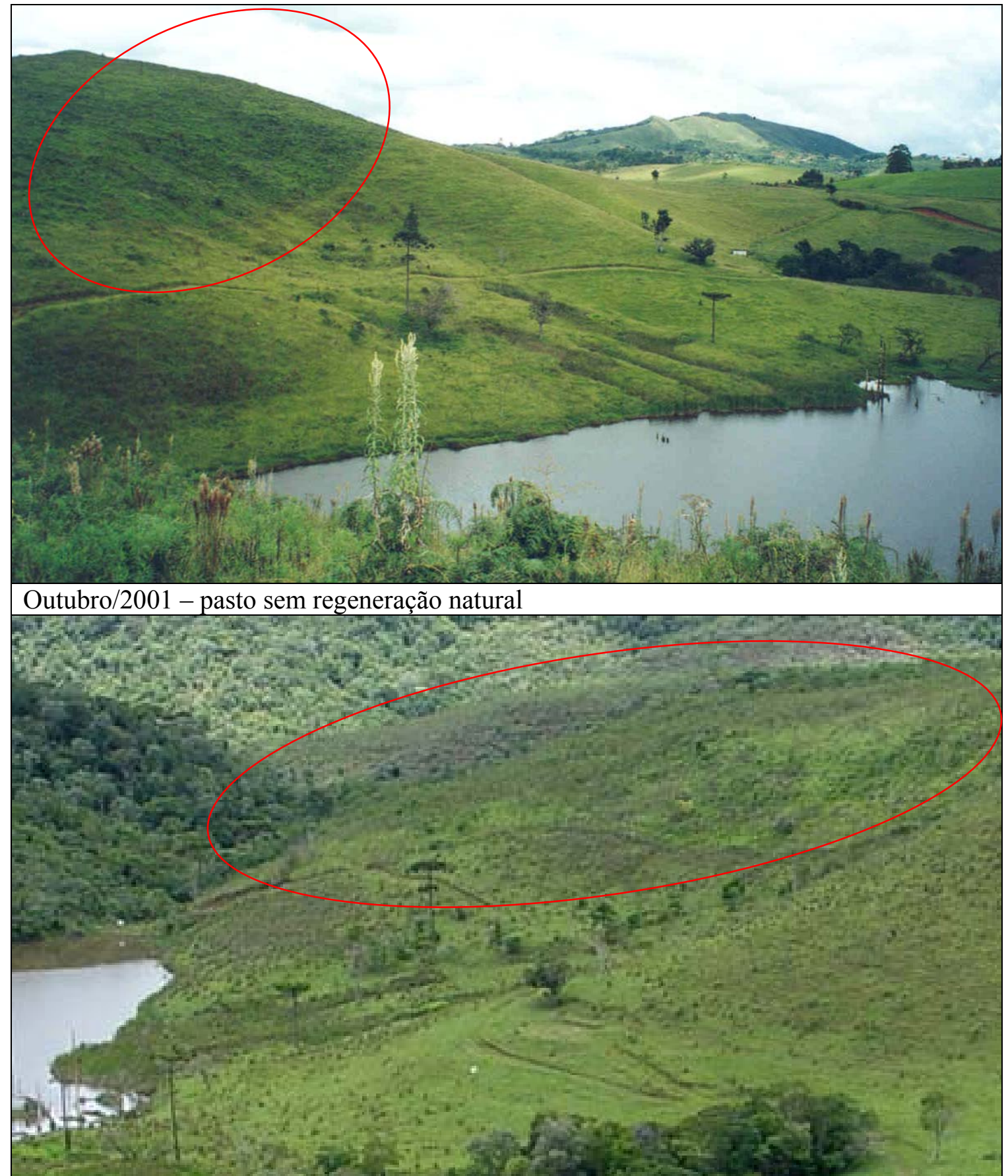

Janeiro/2005 - Pasto com regeneração arbustiva

Figura 16 - Seqüência temporal de antiga área de pasto sem regeneração natural (Tratamento B), atualmente com regeneração arbustiva, Fazenda Intermontes, CCRG, Município de Ribeirão Grande, SP 


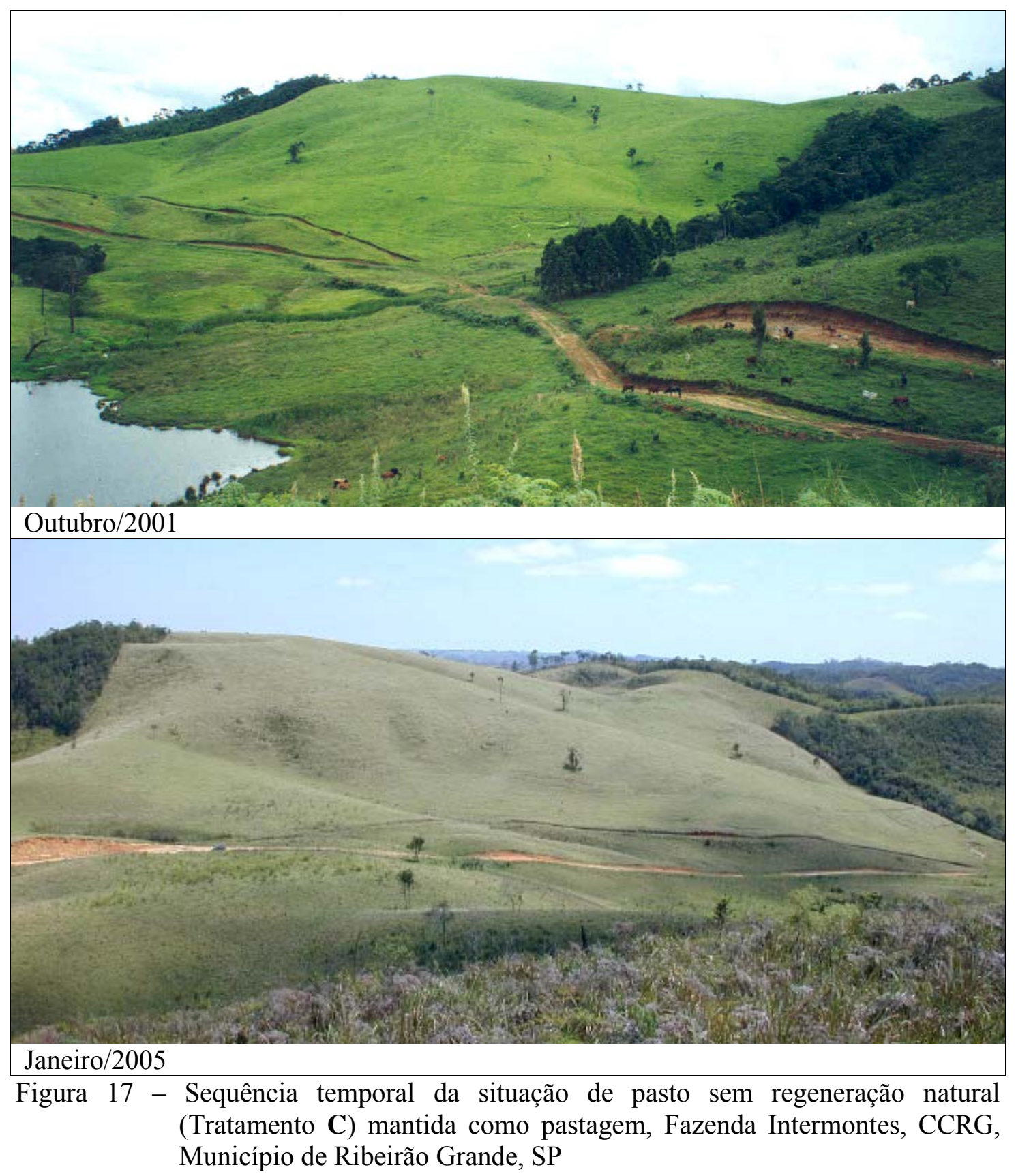

A Figura 18 apresenta a evolução da situação de pasto com regeneração arbustiva, ao longo dos quatro anos de estudo. 


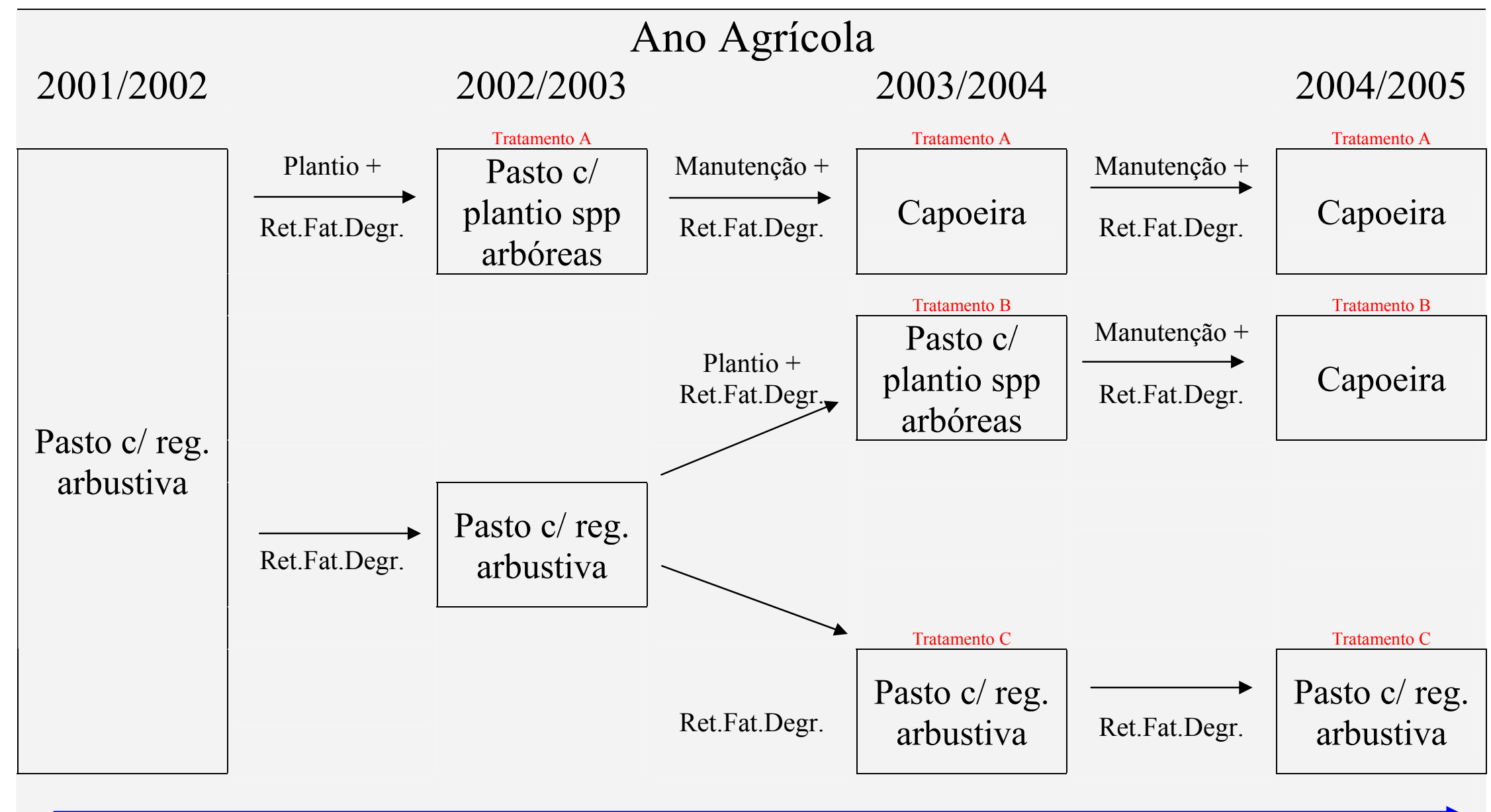

\section{- $\quad$ DIVERSIDADE}

Figura 18 - Fluxograma com os anos agrícolas e a evolução da situação de pasto com regeneração arbustiva em função das ações de restauração. Fazenda Intermontes, CCRG, Município de Ribeirão Grande, SP. Ret.Fat.Degr. = retirada dos fatores de degradação 
As situações de "pasto com regeneração arbustiva" tiveram algumas áreas implantadas no ano agrícola de 2001/2002 e outra parte implantada no ano agrícola de 2002/20003, ficando uma parte ainda sem intervenção direta das atividades de restauração até 2004/2005. Dessa forma, essa situação acabou recebendo três tratamentos: Tratamento A) Retirada de fatores de degradação no primeiro ano com plantio de indivíduos de espécies arbóreas na proporção de 1667 ind./ha no primeiro ano e manutenção anual que constituiu de controle de gramíneas (braquiária) e adubações de cobertura no período chuvoso; Tratamento B) Retirada de fatores de degradação no primeiro ano com posterior plantio de indivíduos de espécies arbóreas na proporção de 1667 ind./ha no segundo ano e manutenção anual; Tratamento C) Apenas retirada dos fatores de degradação.

O Tratamento A, que recebeu a atividade de plantio em 2001/2002 apresentou rapidamente um avanço sucessional para a situação de capoeira no segundo ano após plantio. Isso ocorreu de forma semelhante ao plantio realizado na situação de pasto sem regeneração natural.

No Tratamento B, a evolução da situação ocorreu de forma semelhante ao tratamento A, mas com um ano de atraso, pois as atividades de plantio também foram realizadas com um ano de atraso.

O Tratamento $\mathbf{C}$, apesar de ter sido retirado os fatores de degradação, manteve sua situação original de pasto com regeneração arbustiva inalterada. Os trechos desse Tratamento $\mathbf{C}$ também se encontram em situação desfavorecida na paisagem para chegada de propágulos de espécies arbóreas (Figura 19), por estar em áreas muito declivosas e distantes de fragmentos florestais, sendo necessário a intervenção nessas áreas, através de plantios de espécies arbóreas atrativas da fauna, caso se confirme nas ações de monitoramento que estas espécies não estejam colonizando essas áreas em intensidade suficiente que permita uma restauração em médio prazo. 


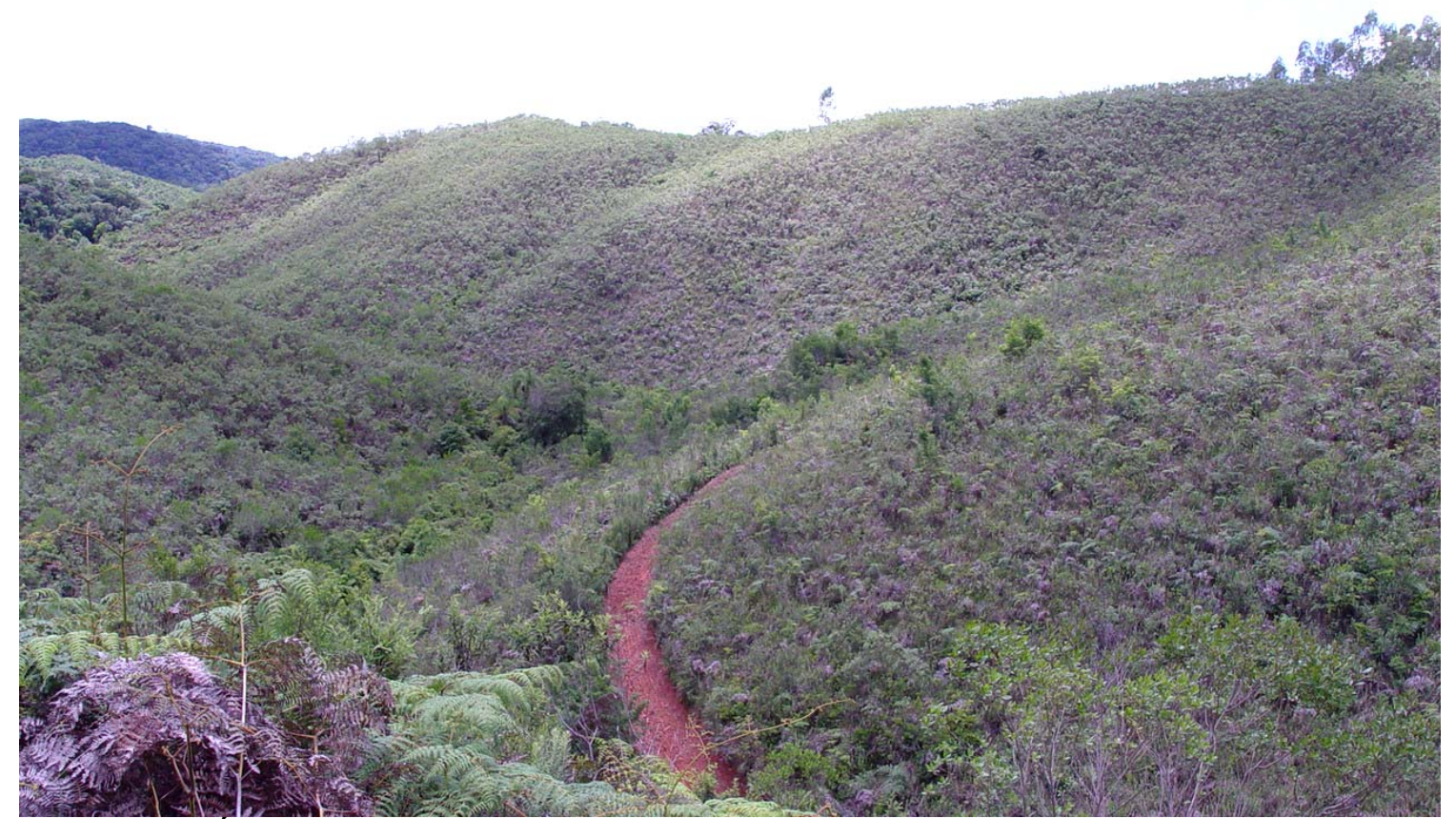

Figura 19 - Área de pasto com regeneração arbustiva em Janeiro de 2005 (Tratamento C) onde não houve evolução sucessional, Fazenda Intermontes, CCRG, Município de Ribeirão Grande, SP

A Figura 20 apresenta a evolução da situação de "pasto com regeneração arbórea". Essa situação se apresentou, no primeiro mapeamento (Tempo Zero), de forma bastante fragmentada na paisagem (Figura 4). Esse fato, aliado a não priorização dessas áreas para restauração num primeiro momento e a possíbilidade de enriquecimento futuro, após monitoramento, acabaram produzindo três tipos de intervenção (tratamentos): Tratamento A) Retirada dos fatores de degradação e manutenção anual que consistiu em controle de gramíneas e adubações de cobertura em período chuvoso; B) Retirada dos fatores de degradação e sem manutenção e; C) Retirada de fatores de degradação nos dois primeiros anos e passagem de fogo pela área no final do ano de 2003. 


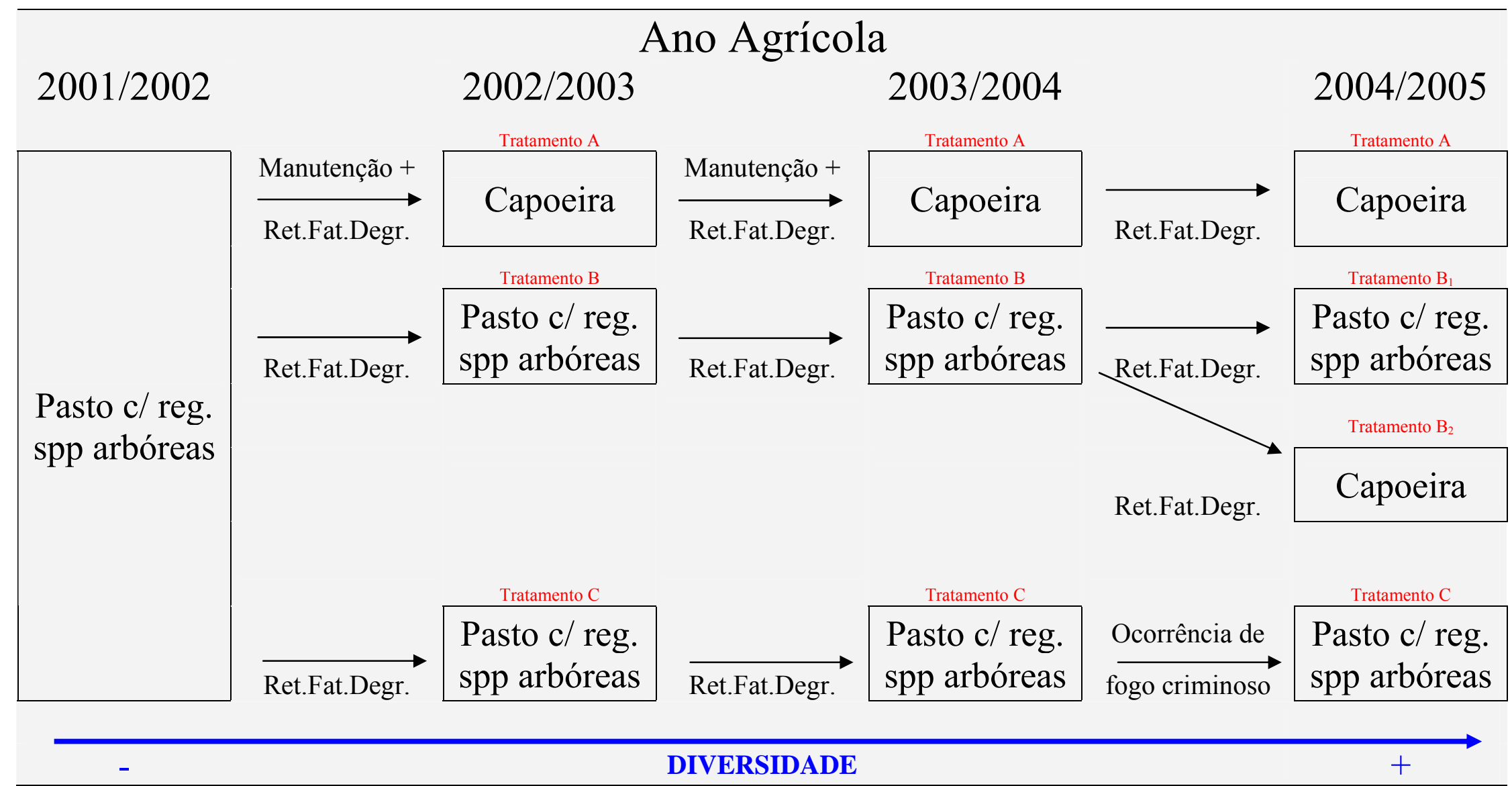

Figura 20 - Fluxograma com os anos agrícolas e a evolução da situação de pasto com regeneração arbórea em função das ações de restauração. Fazenda Intermontes, CCRG, Município de Ribeirão Grande, SP. Ret.Fat.Degr. = retirada dos fatores de degradação 
O Tratamento A apresentou, logo após um ano de intervenção, a evolução da situação de pasto com regeneração arbórea para capoeira (Figuras 21 e 22). Vale ressaltar que, apesar de não ter sido realizado plantio de enriquecimento nessa situação, as manutenções foram intensificadas com controle de competidores e adubação de cobertura.

O Tratamento B teve apenas a retirada dos fatores de degradação de suas áreas. A maior parte delas manteve-se no mesmo estado de pasto com regeneração arbórea, mas uma parte conseguiu evoluir para o estado de capoeira (Figura 23). Essa diferença de evolução sucessional num mesmo tratamento, provavelmente seja fruto da grande heterogeneidade espacial, definindo o potencial de auto-recuperação dessas áreas (Rodrigues \& Gandolfi, 2004). As áreas que evoluíram para situação de capoeira se encontravam na borda de fragmentos florestais, com grande possibilidade de chegada de propágulos. Uma maior densidade e diversidade de indivíduos de espécies arbustivoarbóreas podem ter favorecido essas áreas através da diminuição da competição com as gramíneas, o que não ocorreu nas áreas onde a fisionomia predominante ainda era pasto.

No Tratamento $\mathbf{C}$, as áreas foram isoladas dos fatores de degradação durante os dois primeiros anos após a sua implantação. No entanto, a proximidade dessa situação com a estrada municipal fez com que, em setembro de 2003, houvesse um incêndio acidental na área. O incêndio causou grandes danos aos indivíduos arbóreos que se regeneraram naturalmente na área, reduzindo drasticamente os seus tamanhos. Esse fato colaborou para manter essa área na mesma situação de pasto com regeneração arbórea (Figura 24). 

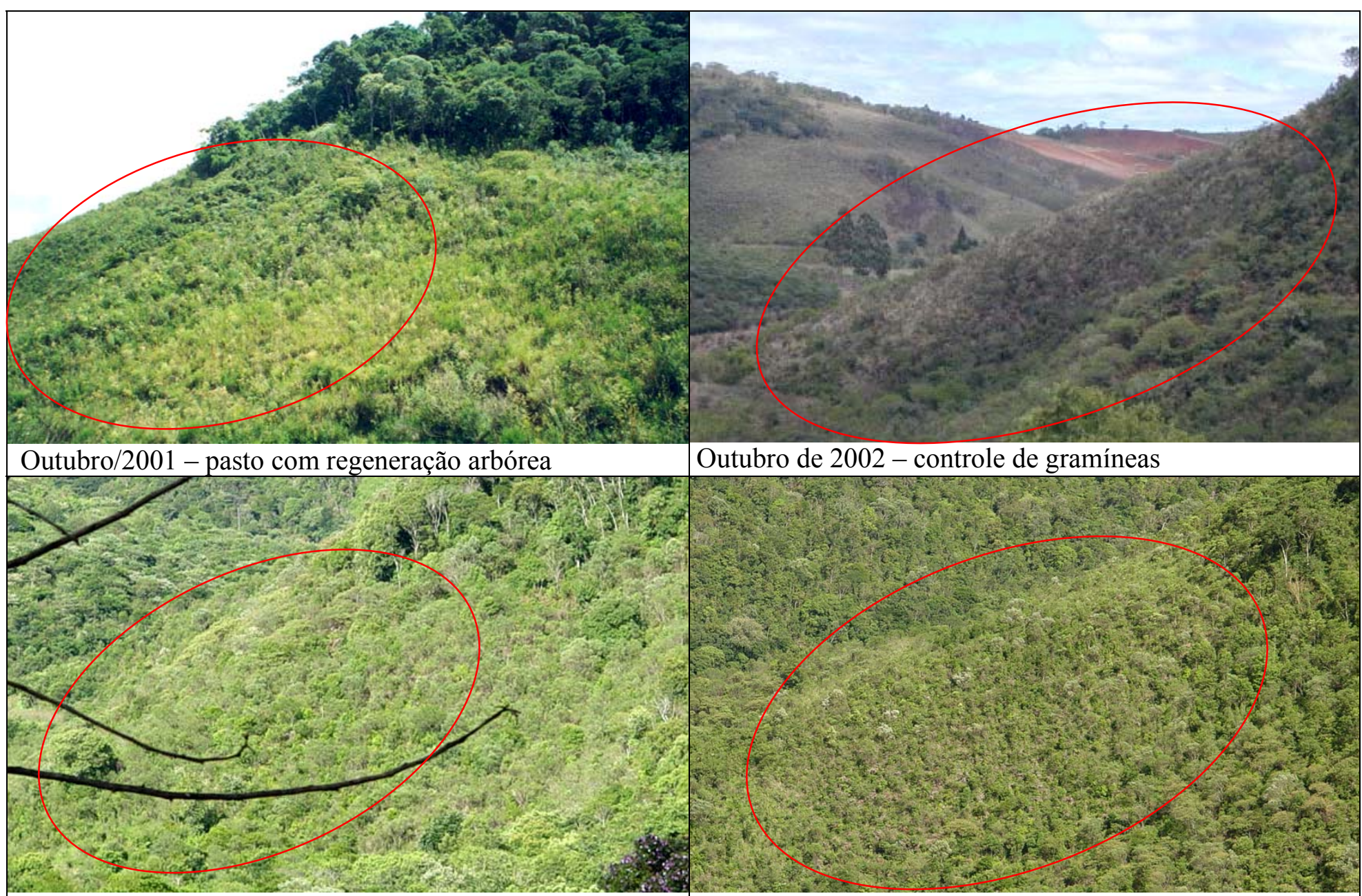

Outubro de 2002 - controle de gramíneas

Janeiro/2005 - formação de capoeira

Janeiro/2005 - formação de capoeira

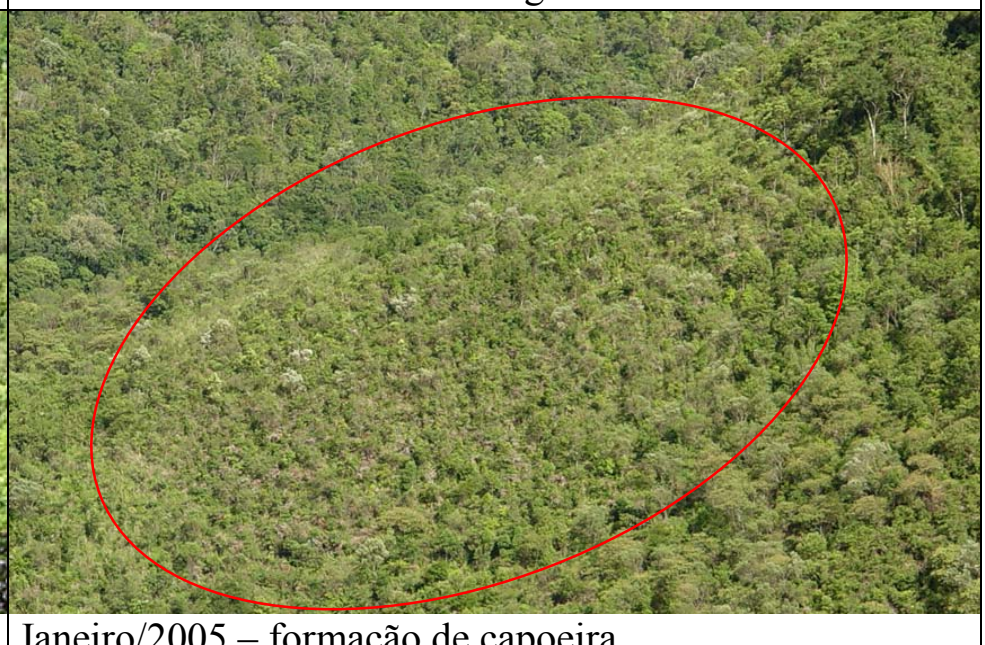

Figura 21 - Sequência temporal da restauração da situação de "pasto com regeneração arbórea" (Tratamento A), passando para a situação de capoeira. Fazenda Intermontes, CCRG, Município de Ribeirão Grande, SP 


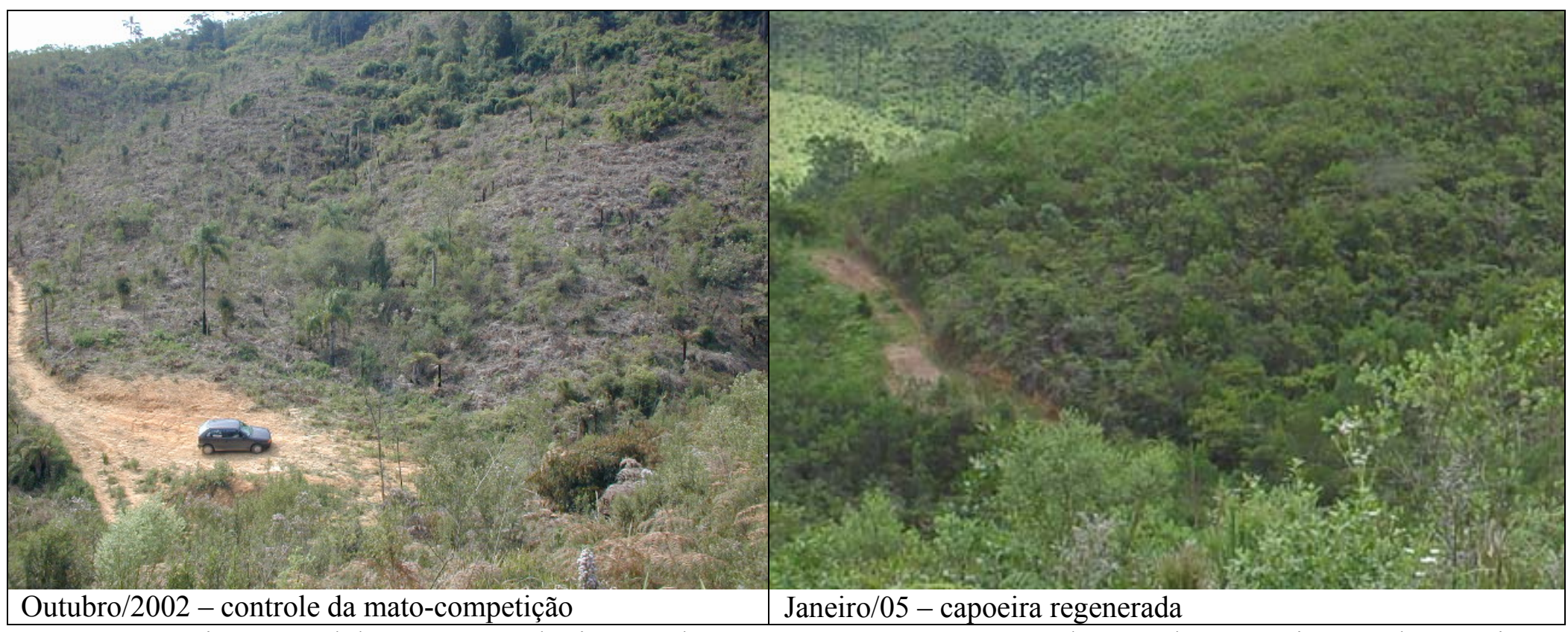

Figura 22- Sequência temporal da restauração da situação de pasto com regeneração natural passando para a situação de capoeira

(Tratamento A). Fazenda Intermontes, CCRG, Município de Ribeirão Grande, SP 


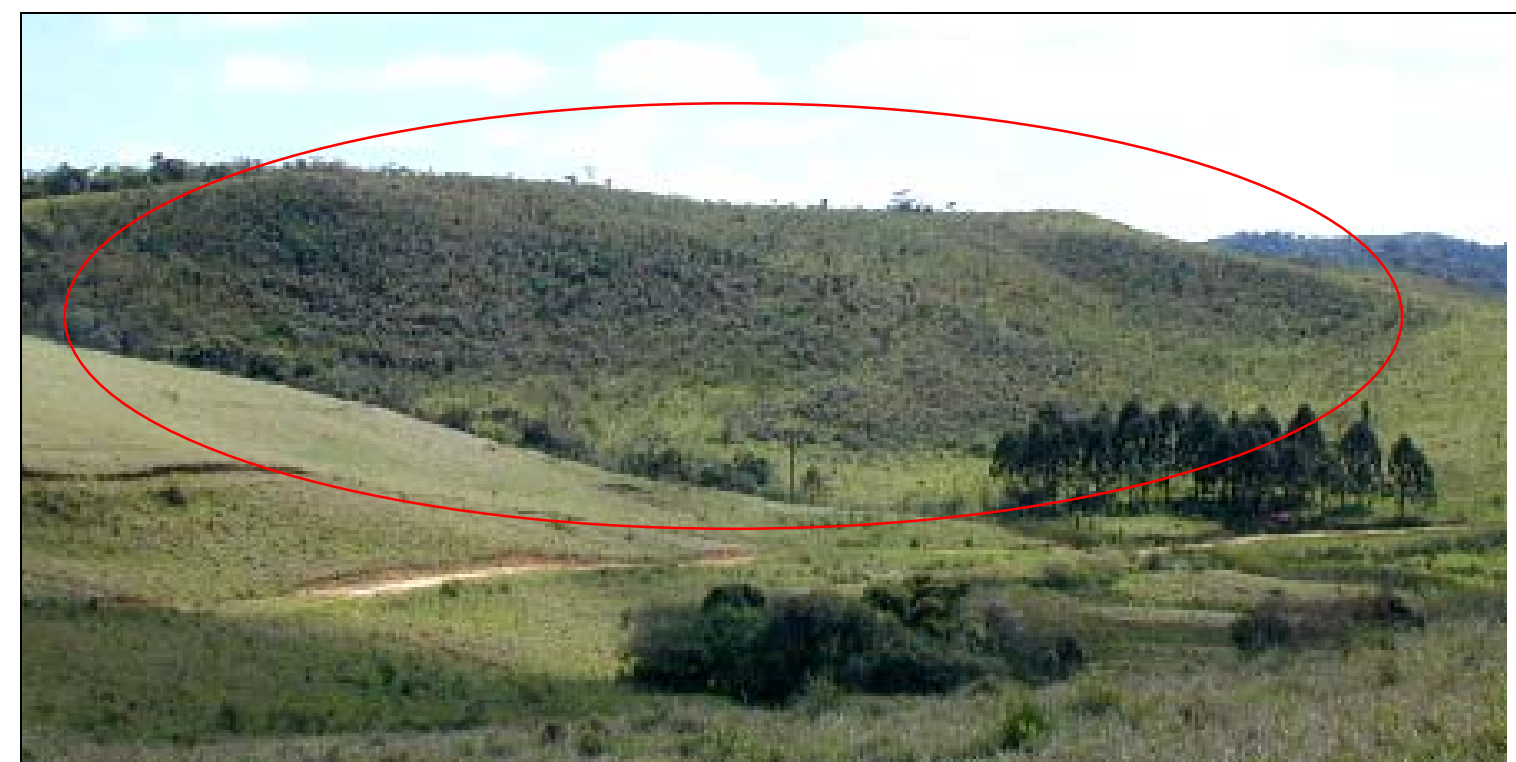

Dutubro/2001 - Pasto com regeneração arbórea - área de difícil mecanização

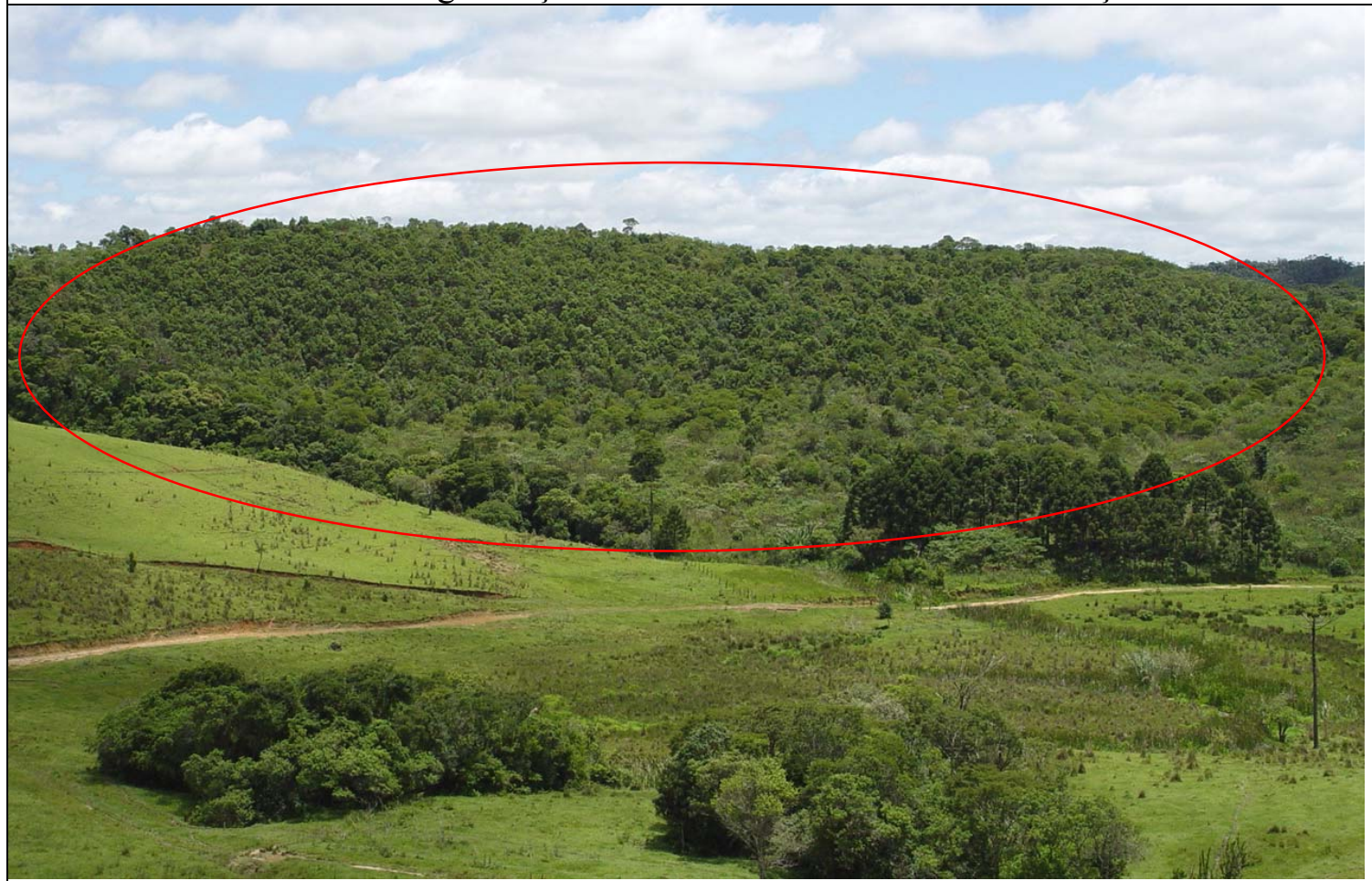

Janeiro/2005 - Capoeira fechada

Figura 23- Sequência temporal da restauração da situação de pasto com regeneração arbórea (Tratamento $\mathbf{B}_{2}$ ), passando para a situação de capoeira: área sem manutenção. Fazenda Intermontes, CCRG, Município de Ribeirão Grande, SP 


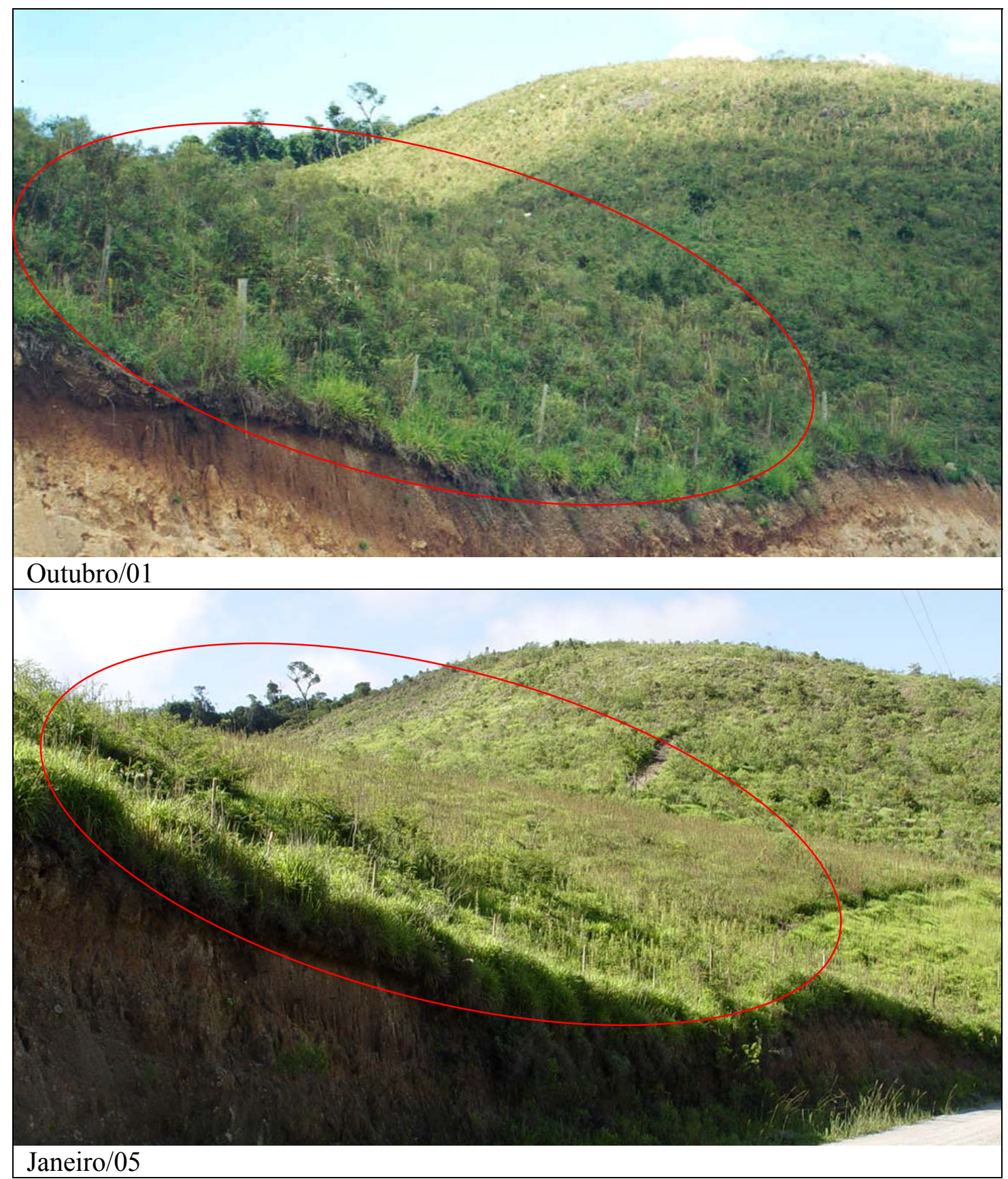

Figura 24 - Situação de pasto com regeneração de espécies arbóreas (Tratamento $\mathbf{C}$ ) onde não teve evolução sucessional ao longo de 4 anos, pelo fato da ocorrência de incêndio criminoso. Local onde ocorreu fogo em setembro de 2003 (Tratamento C). Fazenda Intermontes, CCRG, Município de Ribeirão Grande, SP

As Figuras 25 e 26 apresentam a evolução das situações de capoeira e floresta durante os quatro anos de monitoramento. 


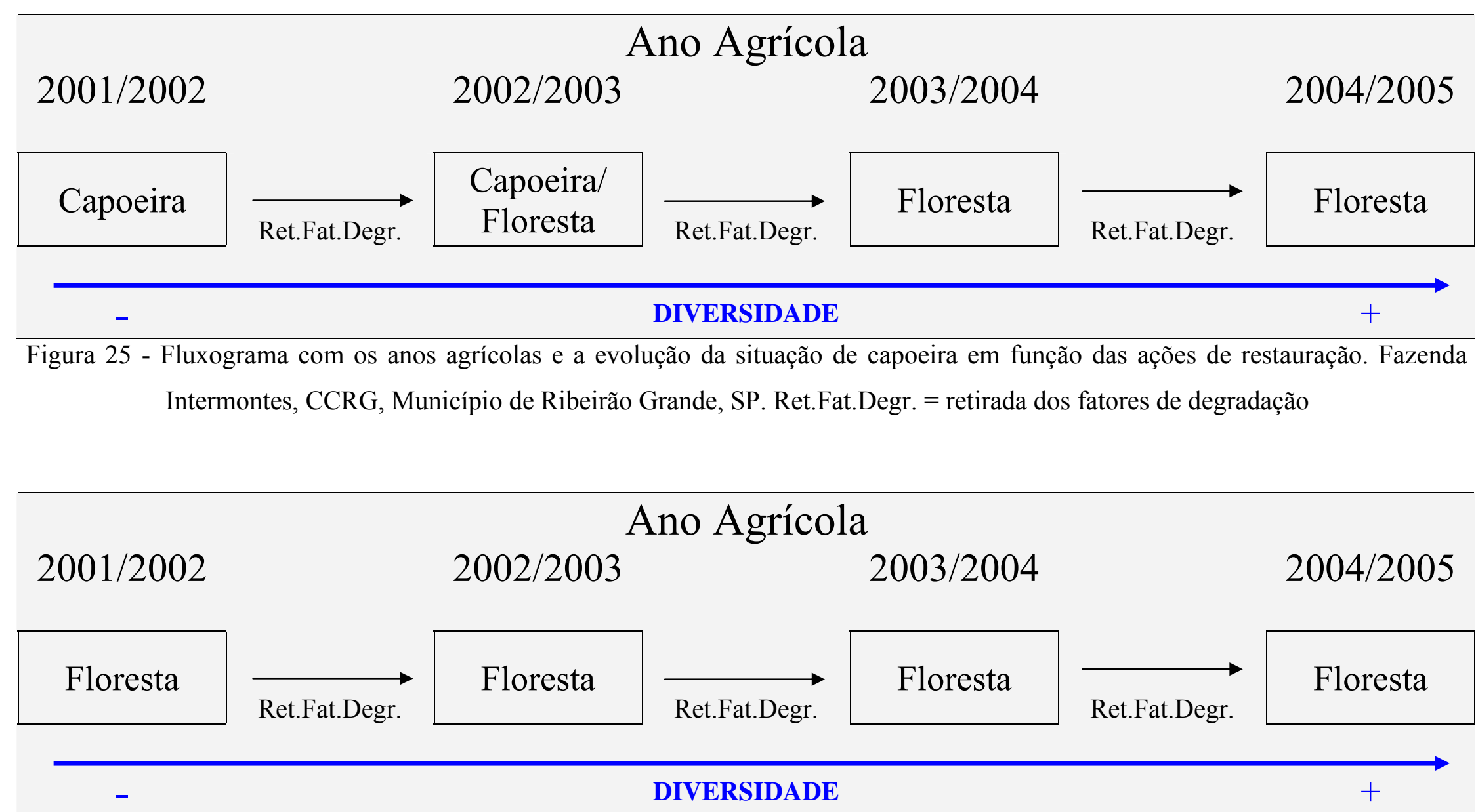

Figura 26 - Fluxograma com os anos agrícolas e a evolução da situação de floresta em função das ações de restauração. Fazenda Intermontes, CCRG, Município de Ribeirão Grande, SP. Ret.Fat.Degr. = retirada dos fatores de degradação 
Nessas duas situações de capoeira e floresta, não foi realizada nenhuma atividade de restauração, exceto a retirada dos fatores de degradação. Assim, o fluxograma destas duas situações não apresenta diferentes tratamentos ao longo do tempo.

As áreas com a situação de capoeira, identificadas no início do trabalho, já possuiam uma boa estrutura e boa diversidade vegetal, mas com porte ainda relativamente baixo e com áreas de dossel descontinuo. Essa boa estrutura, aliada a retirada de fatores de degradação e a possibilidade de recebimento de própagulos fizeram com que houvesse uma rápida evolução dessa situação, sendo classificada atualmente como floresta (Figura 27).

As situações de florestas se mantiveram inalteradas, mas provavelmente caminham para uma condição de maior complexidade, comportando maiores níveis de diversidade do que existiu anteriormente. Isso pode ocorrer em função do isolamento dos possíveis fatores de degradação nessas áreas e da melhoria ambiental da paisagem do entorno, que colabora no restabelecimento dos processos ecológicos da floresta.

Independente dos caminhos para chegar numa floresta madura, isso só será possível através do restabelecimento dos processos ecológicos que regem a dinâmica florestal. Dessa forma, a definição de metodologias de restauração florestal, devem ser voltadas para o restabelecimento desses processos, aumentando as possibilidades de perpetuação dessas areas restauradas.

As áreas identificadas no zoneamento para restauração deverão ser caracterizadas quanto ao seu potencial de auto-recuperação, de forma a subsidiar a escolha da metodologia de restauração a ser adotada. O aproveitamento do potencial de autorecuperação dessas áreas a serem restauradas, certamente possibilitam uma redução dos custos dessa recuperação e uma maior possibilidade de sucesso, já que a efetivação dessa regeneração natural na área em questão, se traduz como uma expressão da própria natureza na tentativa de cicatrização daquela degradação.

No entanto, essas áreas que serão objeto de restauração também deverão ser previamente isoladas dos possíveis fatores de degradação, como fogo, gado, descarga de águas pluviais, etc., de forma que esses fatores não prejudiquem os processos de restauração natural e/ou implantados. 


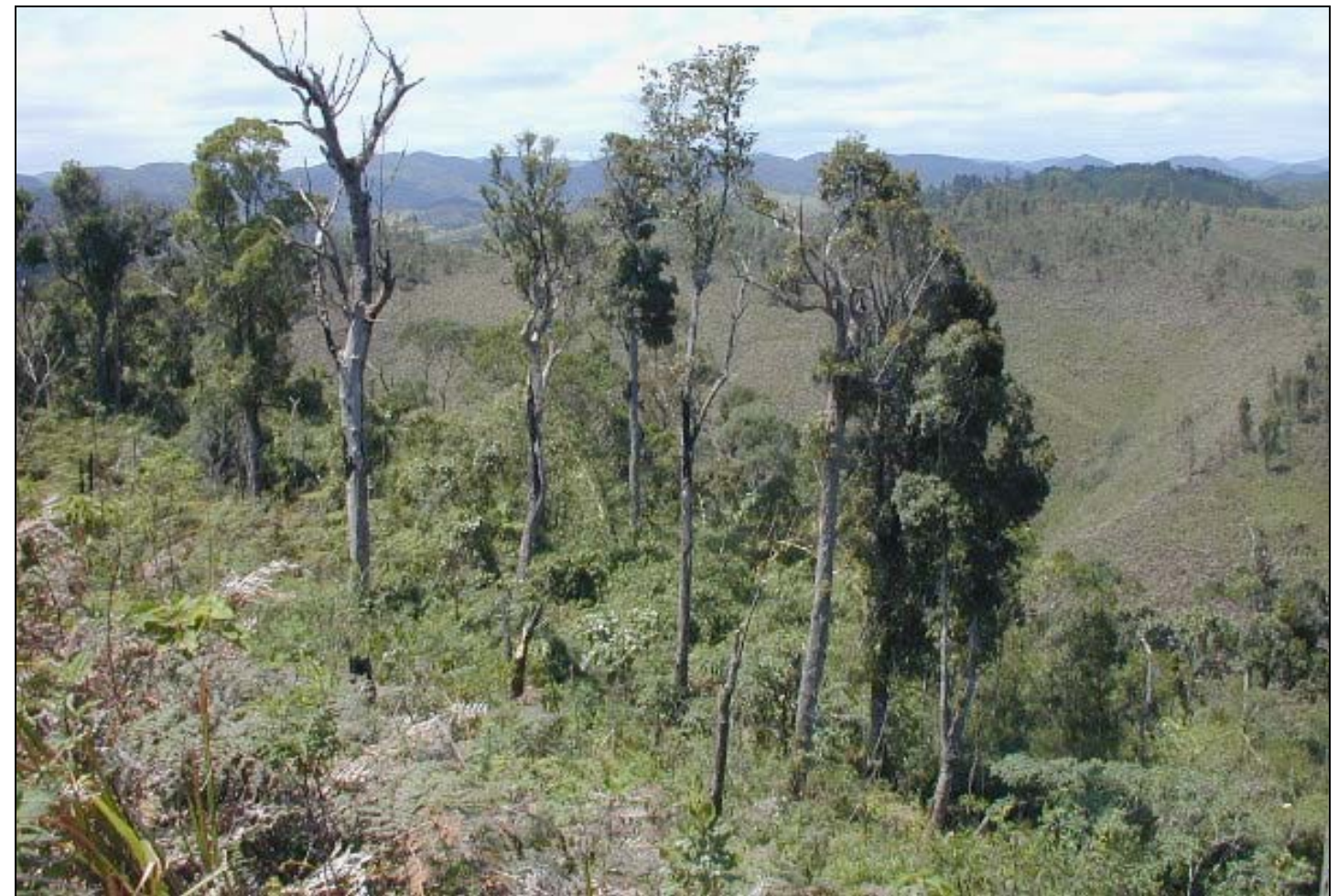

Outubro/2001 - Capoeira formada por incêndio florestal

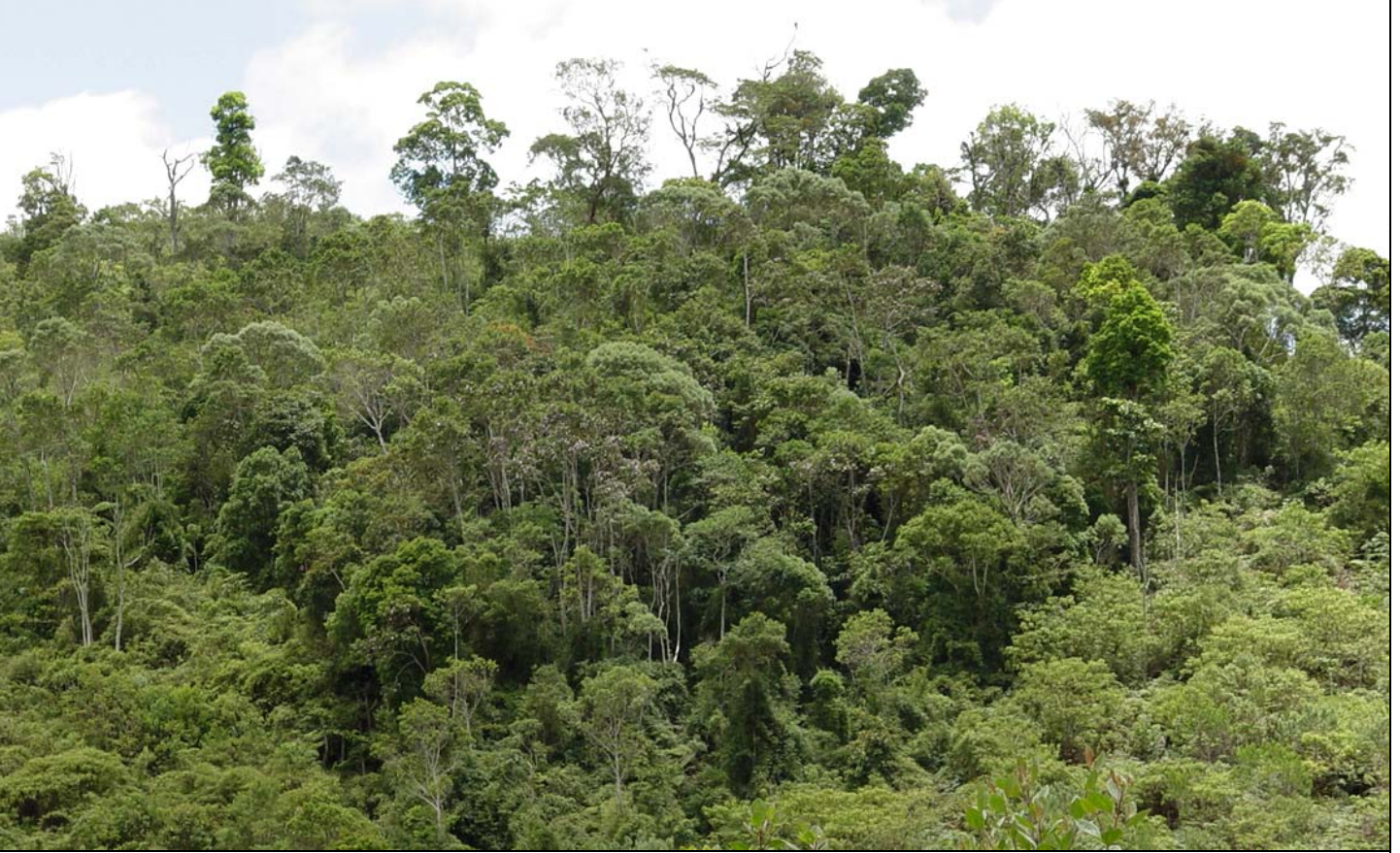

Janeiro/2005 - Floresta recuperada

Figura 27 - Área de capoeira (antiga floresta queimada) e sua recuperação ao longo de quatro anos, com a retirada de fatores de degradação. Fazenda Intermontes, CCRG, Município de Ribeirão Grande, SP 


\subsection{Conclusões}

- As situações de floresta e capoeira se destacam em termos de crescimento de área ocupada nos quatro anos de análise, sendo 70,2\% e $64 \%$ de aumento, respectivamente. As situações de maior degradação, como pasto com regeneração arbórea, pasto sem regeneração natural e solo sem vegetação, tiveram suas áreas iniciais bastante reduzidas nos quatro anos, sendo 49,41\%, 55,70\% e $100 \%$ menores, respectivamente.

- A maior evolução sucessional em termos de área (ha) foi obtida pela situação de capoeira que, apenas através da retirada dos fatores de degradação, foi responsável pelo grande parte do incremento da situação de floresta na paisagem local.

- A situação de solo sem vegetação, onde foi usado o banco de sementes alóctone tiveram suas áreas com uma rápida evolução sucessional, mostrando a viabilidade do uso desse recurso.

- As situações de pasto sem regeneração e pasto com regeneração arbustiva devem receber o plantio em área total e manutenções periódicas, principalmente quando isoladas de fragmentos remanescentes e formadas por espécies competidoras muito agresivas como braquiária. $\mathrm{O}$ avanço sucessional dessas áreas ocorre de forma muito vagarosa em função das espécies competidoras já instaladas no local e da distância das fontes de propágulos.

- A situação de "pasto com regeneração arbórea" necessita de um enriquecimento com espécies de diferentes performances, principalmente atrativas da fauna, para fins de aumento da diversidade. Essa atividade juntamente com o controle de espécies exóticas agressivas e adubação dos indivíduos arbóreos regenerantes, irão acelerar os processos de restauração florestal.

- O monitoramento da evolução da paisagem mostrou a importância da retirada dos fatores de degradação das situações em restauração. Essa ação pode acelerar os processos de regeneração natural, colaborando e barateando as outras atividades de restauração. 
- Neste trabalho, ficou claro a importância da particularização das ações de restauração em função das características locais (uso histórico e atual) e do entorno (presença de fragmentos florestais remanescentes). Isso permitirá a conquista dos objetivos propostos com maior eficiência e custos de implantação, aumentando as chances de perpetuação das áreas restauradas. 


\section{CONCLUSÕES GERAIS}

- O potencial de recuperação de uma determinada área a ser restaurada está diretamente ligada ao seu histórico de uso, cobertura atual e possibilidade de recebimento ou não de propágulos oriundos de fragmentos naturais remanescentes no entorno. Neste trabalho, foi constatado que as situações ambientais, identificadas na Fazenda Intermontes e originadas de diferentes formas de uso e ocupação do solo, apresentaram diferentes expressões de regeneração natural, em função do número de indivíduos de espécies arbustivo-arbóreas germinados banco de sementes autóctone. Assim, foi possível relacionar a densidade do banco de sementes autóctone com os níveis de degradação das situações ambientais da Fazenda Intermontes. A maior densidade de indivíduos de espécies arbustivo-arbóreas germinados foi da situação de floresta, que apresentou o número estimado de 690.000 indivíduos/ha (69,0 indivíduos $/ \mathrm{m}^{2}$ ). As outras situações de pasto com regeneração arbustiva, pasto com regeneração arbórea e capoeira apresentaram $42.500\left(4,2\right.$ indivíduos $\left./ \mathrm{m}^{2}\right), 67.500(6,8$ indivíduos $/ \mathrm{m}^{2}$ )e 472.500 indivíduos $/$ ha $\left(47,3\right.$ indivíduos $\left./ \mathrm{m}^{2}\right)$, respectivamente. A situação de pasto sem regeneração natural, não apresentou banco de sementes de indivíduos de espécies arbustivo-arbóreas.

- A existência de um potencial de regeneração natural pode ser percebida através da presença de indicadores no ambiente. Os resultados da germinação do banco de sementes autóctone mostraram que presença de alguns indivíduos de espécies arbustivo-arbóreas regenerantes, na fisionomia da área a ser restaurada, estava relacionada à presença de banco de sementes da mesma forma de vida no solo. $\mathrm{O}$ reconhecimento desses indicadores no campo é fundamental para a definição de medidas de restauração do local. 
- A possibilidade de uso de banco de sementes alóctone foi viável em áreas de restauração onde não havia cobertura vegetal (solo sem vegetação). A densidade dos indivíduos de espécies arbustivo-arbóreas germinados se mostrou bastante elevada, com aproximadamente 409.334 indivíduos/ha, revelando a possibilidade de uso do banco de sementes alóctone como uma das metodologias de restauração de áreas degradadas.

- Apesar da alta densidade de indivíduos encontrados nos bancos de sementes autóctone e alóctone, foi constatada baixa riqueza de espécies arbustivo-arbóreas entre os indivíduos regenerantes. Entretanto, deve ser considerado que várias outras formas de vida não contabilizadas, como arbustos, herbáceas e lianas não agressivas, foram introduzidas com o solo contendo o banco de sementes alóctone, contribundo no aumento da diversidade.

- A densidade dos indivíduos de espécies arbustivo-arbóreas resgatados em julho (38.700 ind./ha e dezembro (37.900 ind./ha), mostrou o grande potencial desta técnica, uma vez que, foi possível alcançar até $70,9 \%$ de sobrevivência para os indivíduos resgatados em dezembro de 2002, com altura entre 04 e $20 \mathrm{~cm}$. Esse método deve ser recomendado principalmente em empreendimentos com áreas que serão desmatadas como forma de medida mitigadora dos impactos gerados.

- Considerando que os indivíduos de espécies arbustivo-arbóreas representam apenas cerca de 45 a $50 \%$ do total de indivíduos encontrados em uma floresta, esta técnica pode ser expandida para as outras formas de vida como epífitas, lianas não agressivas e herbáceas, as quais também fazem parte da dinâmica florestal, garantindo a continuidade dos processos ecológicos na área restaurada.

- A análise do modelo de plantio usando os conceitos de Preenchimento e de Diversidade mostraram o estabelecimento de um número elevado de espécies, demonstrando que a função do grupo da diversidade vem sendo mantida ao longo dos anos, aumentando as chances de efetivação dos processos de sucessão. $\mathrm{O}$ grupo de Preenchimento apresentou-se com uma porcentagem de cobertura significativamente maior que a do grupo de Diversidade, cumprindo sua principal função no processo de restauração. Isso ocorreu tanto para o reflorestamento com a 
idade de 1,5 anos como para o reflorestamento com a idade de 2,5 anos, sendo que para 1,5 anos a diferença de cobertura foi de 73,6\% maior para o grupo de Preenchimento em relação ao grupo de Diversidade e para 2,5 anos essa diferença foi de $83,3 \%$. Dessa forma, pode-se concluir que foi possível combinar as espécies florestais com alta diversidade em grupos de preenchimento e diversidade, obtendo um recobrimento eficiente da área em restauração, que deverá garantir a perpetuação da área restaurada.

- A simulação de modelos de plantio com diferentes arranjos, espaçamentos entre plantas e usando os parâmetros de cobertura média dos indivíduos dos dois grupos de plantio, mostrou a possibilidade do modelo utilizado ser melhorado no sentido de aumentar a eficiência do recobrimento da área, através da menor competição entre os indivíduos plantados. Dessa forma, esses novos modelos teóricos deverão ser testados em campo para comprovar a sua maior eficácia.

- O monitoramento da evolução da paisagem na Fazenda Intermontes mostrou a importância da retirada dos fatores de degradação das situações em restauração. Essa ação pode acelerar os processos de regeneração natural, colaborando e barateando as outras atividades de restauração.

- A caracterização do tipo de ocupação atual baseada principalmente nas potencialidades de recuperação dessas áreas permitiu a definição de ações diferenciadas de restauração para cada uma das situações identificadas, visando desencadear e conduzir os processos naturais de restauração. Dessa forma, parte da vegetação natural poderá se restabelecer a partir da regeneração natural, se esta for adequadamente induzida e conduzida em ações de manejo. Isso tem como conseqüência não só a redução dos custos da adequação ambiental, mas também uma maior garantia de sucesso dessas ações.

- Na restauração ecológica, deve ser garantida a substituição gradual de espécies com diferentes grupos de comportamentos através da reintrodução de elevada diversidade de espécies, restabelecendo os processos ecológicos e garantindo a perpetuação da área. A metodologia em questão deverá ainda ser passível de implantação no campo, em pequenas e grandes escalas, de forma a promover a mais rápida e eficiente 
cobertura florestal da área em processo de restauração, reduzindo assim os custos de manutenção. 


\section{ANEXOS}

Parâmetros fitossociológicos das espécies arbustivo-arbóreas resgatadas na Mina Limeira em julho de 2002, município de Ribeirão Grande, SP. $\mathrm{N}^{\circ}$ Ind. = número de indivíduos; Dens.Rel. $=$ densidade relativa (\%); Freq.Rel. $=$ frequência relativa $(\%)$.

\begin{tabular}{|c|c|c|c|}
\hline Espécie & Ind I & ens. Re & req. Rel. \\
\hline--------------- & . & & \\
\hline Prunus myrtifolia .......... & 111 & 14.34 & 7.20 \\
\hline Ocotea corymbosa ........... & 124 & 16.02 & 3.03 \\
\hline Cupania vernalis .......... & 98 & 12.66 & 5.68 \\
\hline Ocotea dispersa ............ & 70 & 9.04 & 6.06 \\
\hline Dalbergia frutescens ........ & 43 & 5.56 & 6.82 \\
\hline Sebastiania serrata ....... & 42 & 5.43 & 6.06 \\
\hline Matayba guianensis ......... & 25 & 3.23 & 5.30 \\
\hline Geonoma brevispatha ........ & 26 & 3.36 & 4.92 \\
\hline 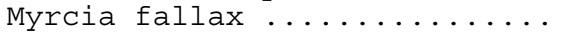 & 28 & 3.62 & 3.79 \\
\hline Nectandra leucantha.......... & 15 & 1.94 & 5.30 \\
\hline Mollinedia widgrenii ........ & 15 & 1.94 & 4.92 \\
\hline Maytenus robusta ........... & 15 & 1.94 & 3.79 \\
\hline Sorocea bonplandii ......... & 17 & 2.20 & 3.03 \\
\hline Piptadenia paniculata........ & 18 & 2.33 & 2.65 \\
\hline Copaifera langsdorffii ...... & 11 & 1.42 & 3.03 \\
\hline 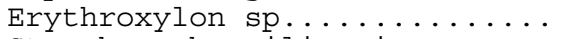 & 11 & 1.42 & 3.03 \\
\hline Strychnos brasiliensis ...... & 11 & 1.42 & 1.89 \\
\hline Senna multijuga ........... & 9 & 1.16 & 1.14 \\
\hline Esenbeckia grandiflora ....... & 5 & 0.65 & 1.89 \\
\hline Tibouchina pulchra ......... & 7 & 0.90 & 1.14 \\
\hline Rapanea umbellata ...... & 7 & 0.90 & 1.14 \\
\hline Rollinia sylvatica ......... & 5 & 0.65 & 1.52 \\
\hline Allophylus edulis .......... & 6 & 0.78 & 1.14 \\
\hline Rapanea ferruginea ......... & 4 & 0.52 & 1.52 \\
\hline Eugenia pluriflora ......... & 5 & 0.65 & 1.14 \\
\hline 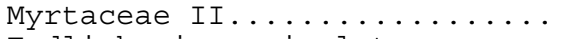 & 6 & 0.78 & 0.76 \\
\hline Endlicheria paniculata ...... & 4 & 0.52 & 1.14 \\
\hline Zanthoxylun rhoifolium ...... & 4 & 0.52 & 1.14 \\
\hline Nectandra megapotamica ...... & 3 & 0.39 & 0.76 \\
\hline 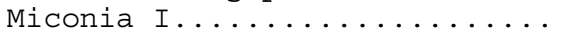 & 3 & 0.39 & 0.76 \\
\hline 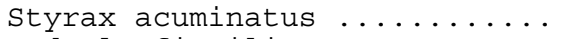 & 2 & 0.26 & 0.76 \\
\hline 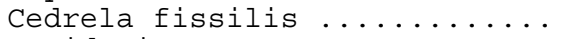 & 2 & 0.26 & 0.76 \\
\hline Gomidesia sp $2 \ldots \ldots \ldots$ & 2 & 0.26 & 0.76 \\
\hline Cordia ecalyculata ......... & 2 & 0.26 & 0.76 \\
\hline Campomanesia guaviroba ....... & 3 & 0.39 & 0.38 \\
\hline Machaerium stipitatum ....... & 2 & 0.26 & 0.38 \\
\hline Ilex cf taubertiana ......... & 2 & 0.26 & 0.38 \\
\hline Vochysia tucanorum ......... & 1 & 0.13 & 0.38 \\
\hline Gomidesia sp $1 \ldots . . . . . .$. & 1 & 0.13 & 0.38 \\
\hline Sloanea monosperma ......... & 1 & 0.13 & 0.38 \\
\hline Solanum argenteum ... & 1 & 0.13 & 0.38 \\
\hline Croton lindenianus ......... & 1 & 0.13 & 0.38 \\
\hline Bauhinia forficata ......... & 1 & 0.13 & 0.38 \\
\hline Piptadenia gonoacantha ...... & 1 & 0.13 & 0.38 \\
\hline Aspidosperma parvifolium .... & 1 & 0.13 & 0.38 \\
\hline Cabralea canjerana ......... & 1 & 0.13 & 0.38 \\
\hline 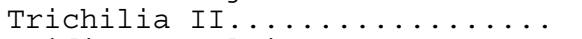 & 1 & 0.13 & 0.38 \\
\hline Psidium cattleianum & 1 & 0.13 & 0.38 \\
\hline
\end{tabular}


Parâmetros fitossociológicos das espécies arbustivo-arbóreas resgatadas na Mina Limeira em dezembro de 2002, município de Ribeirão Grande, SP. $\mathrm{N}^{\circ}$ Ind. = número de indivíduos; $\mathrm{N}^{\circ}$ Par. = número de parcelas; Dens.Rel. $=$ densidade relativa (\%); Freq. Rel. = frequência relativa (\%).

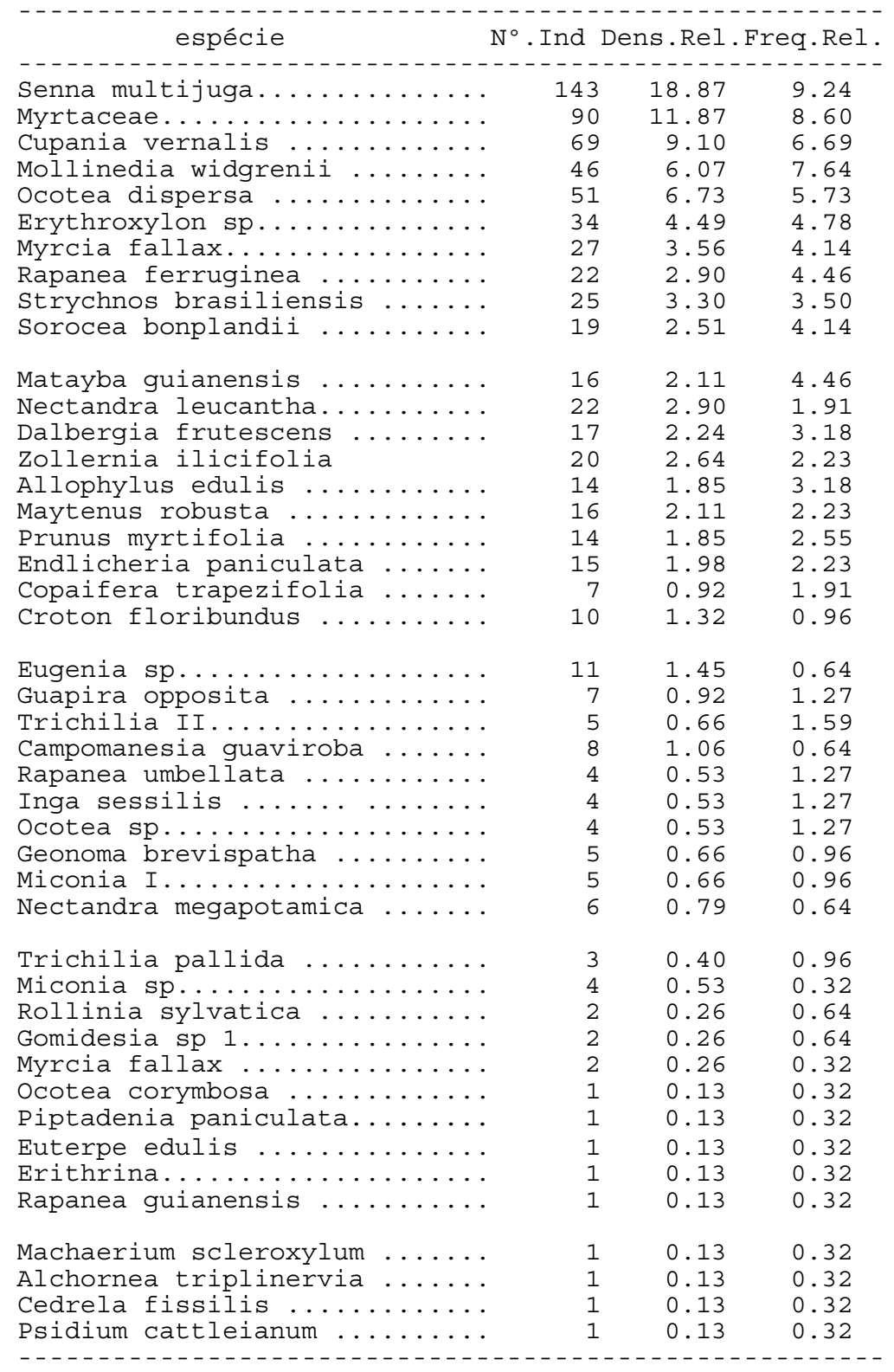


Parâmetros fitossociológicos das espécies arbustivo-arbóreas sobreviventes do resgate realizado em julho de 2002, município de Ribeirão Grande, SP. $\mathrm{N}^{\circ}$ Ind. = número de indivíduos; $\mathrm{N}^{\mathrm{o}}$ Par. $=$ número de parcelas; Dens.Rel. $=$ densidade relativa (\%); Freq. Rel. $=$ frequência relativa $(\%)$.

\begin{tabular}{|c|c|c|c|}
\hline \multicolumn{4}{|c|}{ 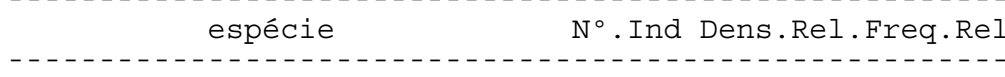 } \\
\hline Ocotea dispersa .......... & 46 & 13.94 & 7.84 \\
\hline Ocotea corymbosa ........... & 42 & 12.73 & 4.58 \\
\hline Dalbergia frutescens ........ & 33 & 10.00 & 9.80 \\
\hline Prunus myrtifolia .......... & 34 & 10.30 & 9.15 \\
\hline Cupania vernalis ........... & 29 & 8.79 & 4.58 \\
\hline Sebastiania serrata ........ & 21 & 6.36 & 7.19 \\
\hline Mollinedia widgrenii ........ & 10 & 3.03 & 6.54 \\
\hline Geonoma brevispatha ........ & 12 & 3.64 & 5.23 \\
\hline 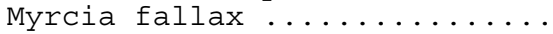 & 10 & 3.03 & 2.61 \\
\hline Matayba guianensis .......... & 7 & 2.12 & 3.92 \\
\hline Strychnos brasiliensis ...... & 9 & 2.73 & 2.61 \\
\hline 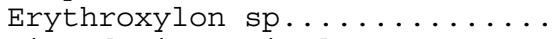 & 6 & 1.82 & 3.27 \\
\hline Piptadenia paniculata........ & 7 & 2.12 & 1.96 \\
\hline Senna multijuga............ & 8 & 2.42 & 1.31 \\
\hline 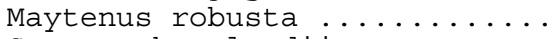 & 5 & 1.52 & 2.61 \\
\hline Sorocea bonplandii ......... & 6 & 1.82 & 1.96 \\
\hline Rapanea umbellata ........... & 5 & 1.52 & 1.31 \\
\hline Allophylus edulis .......... & 5 & 1.52 & 1.31 \\
\hline Nectandra leucantha.......... & 3 & 0.91 & 1.96 \\
\hline Rapanea ferruginea .......... & 3 & 0.91 & 1.96 \\
\hline Rollinia sylvatica ......... & 3 & 0.91 & 1.96 \\
\hline Esenbeckia grandiflora ...... & 2 & 0.61 & 1.31 \\
\hline Copaifera langsdorffii ...... & 2 & 0.61 & 1.31 \\
\hline Cordia ecalyculata .......... & 2 & 0.61 & 1.31 \\
\hline Nectandra megapotamica ...... & 2 & 0.61 & 1.31 \\
\hline Zanthoxylun rhoifolium ....... & 2 & 0.61 & 1.31 \\
\hline 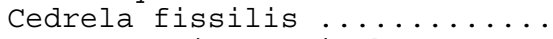 & 2 & 0.61 & 1.31 \\
\hline Campomanesia guaviroba ....... & 2 & 0.61 & 0.65 \\
\hline Ilex cf taubertiana ......... & 1 & 0.30 & 0.65 \\
\hline 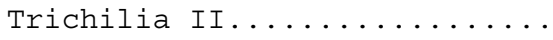 & 1 & 0.30 & 0.65 \\
\hline Machaerium stipitatum ...... & 1 & 0.30 & 0.65 \\
\hline 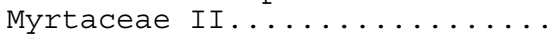 & 1 & 0.30 & 0.65 \\
\hline Sloanea monosperma ......... & 1 & 0.30 & 0.65 \\
\hline Piptadenia gonoacantha....... & 1 & 0.30 & 0.65 \\
\hline Solanum argenteum .......... & 1 & 0.30 & 0.65 \\
\hline Bauhinia forficata .......... & 1 & 0.30 & 0.65 \\
\hline Tibouchina pulchra ......... & 1 & 0.30 & 0.65 \\
\hline Aspidosperma parvifolium .. & 1 & 0.30 & 0.65 \\
\hline Cabralea canjerana .......... & 1 & 0.30 & 0.65 \\
\hline Psidium cattleianum ........ & 1 & 0.30 & 0.65 \\
\hline
\end{tabular}


Parâmetros fitossociológicos das espécies arbustivo-arbóreas sobreviventes do resgate realizado em dezembro de 2002, município de Ribeirão Grande, SP. $\mathrm{N}^{\circ}$ Ind. = número de indivíduos; Dens.Rel. = densidade relativa (\%); Freq. Rel. $=$ frequência relativa $(\%)$.

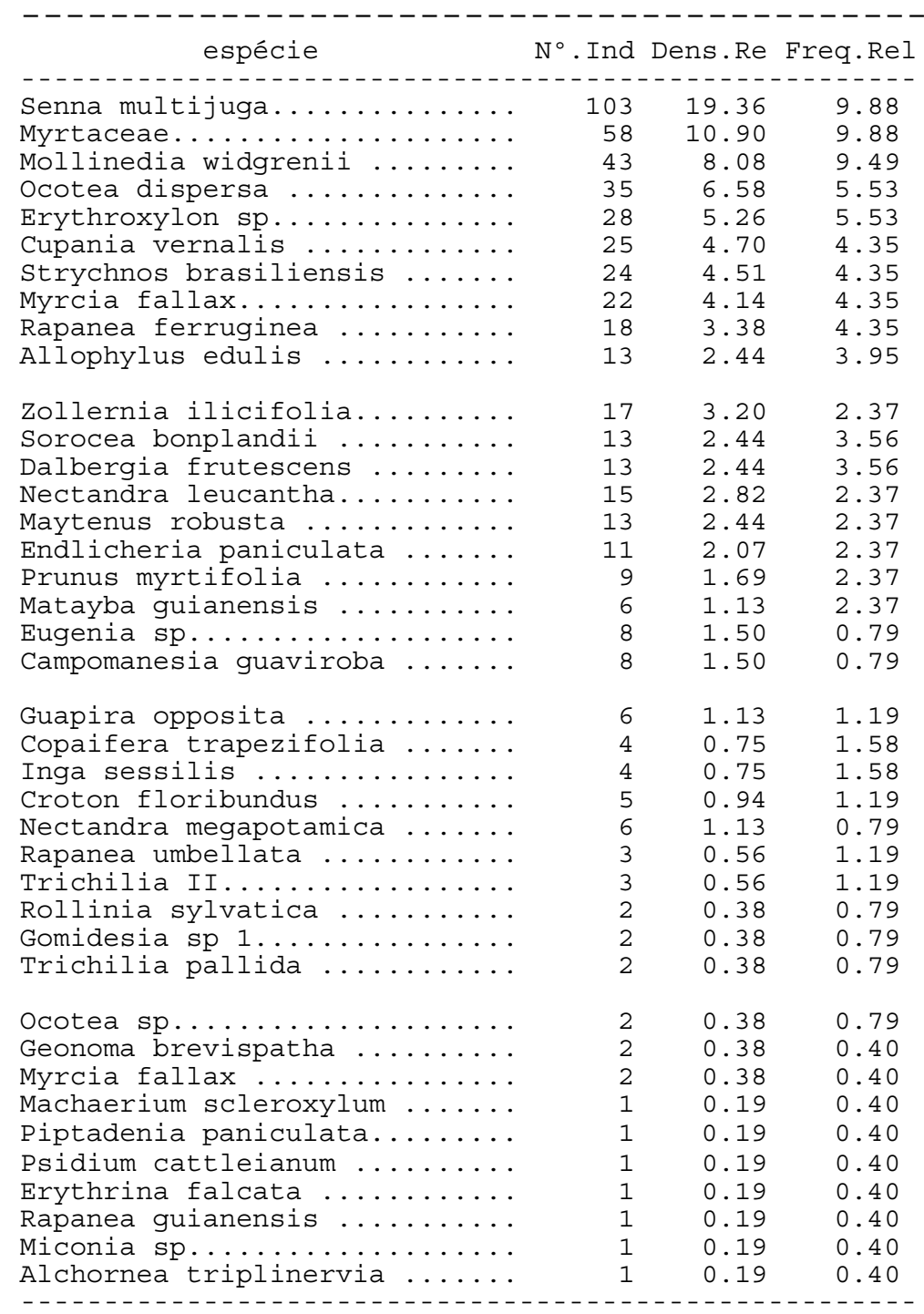




\section{REFERÊNCIAS BIBLIOGRÁFICAS}

ALBUQUERQUE, G.B. Floresta Nacional de Ipanema: caracterização da vegetação em dois trechos distintos do Morro de Araçoiaba, Iperó, SP. Piracicaba, 1999. 186p. Dissertação (Mestrado) - Escola Superior de Agricultura "Luiz de Queiroz", Universidade de São Paulo.

ALMEIDA-CORTEZ, J.S. Dispersão e banco de sementes. In: FERREIRA, A.G.; BORGHETTI, F. (Org.). Germinação: do básico ao aplicado. Porto Alegre: Artmed, 2004. p.225 - 235.

ANGIOSPERM PHYLOGENY GROUP II. An update of the Angiosperm Phylogeny Group classification for the orders and families of flowering plants: APG II. Botanical Journal of the Linnaean Society, v.141 n.4, p.399-436, 2003.

ARAKI, D.F.; RODRIGUES, R.R. Avaliação da semeadura a lanço de espécies florestais nativas para recuperação de áreas degradadas (três condições de substratos, com e sem incorporação do solo), Sales de Oliveira, SP. In: CONGRESSO DE ECOLOGIA DO BRASIL, 6., Fortaleza, 2003. Anais. Fortaleza: UFCe, 2003. v.1. p. $427-428$.

ARAÚJO L.S.; BATISTA-MARIA V.R..; TONELLO, V. et al. A cobertura de vegetação como indicador de métodos de restauração. Piracicaba: ESALQ, Depto. de Ciências Florestais, 2004. (Relatório técnico).

ARONSON, J.; FLORET, C.; FLOC'H, E. et al. restoration and rehabilitation of degraded ecosystems in arid and semiarid lands. Restoration Ecology, v.1, n.3, p.168-186, 1993. 
BAIDER, C.; TABARELLI, M.; MANTOVANI, W. The soil seed bank during Atlântic Forest regeneration in southeast Brazil. Revista Brasileira de Biologia, v. 61, p. 3544, 2001.

BARBOSA, D.C.A.; SILVA, P.G.G.; BARBOSA, M.C.A. Tipos de frutos e síndrome de dispersão de espécies lenhosas da caatinga de Pernanbuco. In: TABARELLI, M.; SILVA, J.M.C. Diagnóstico da biodiversidade de Pernambuco. Recife Massangan, 2002. v.2, p. 609-622.

BARBOSA, L.M. Contribuições para planejamento estratégico do programa de repovoamento vegetal do Estado de São Paulo. In: WORSHOP MATAS CILIARES, São Paulo, 2002. São Paulo: Secretaria do Meio Ambiente do Estado de São Paulo, 2002.

BARBOSA, L.M. Considerações gerais e modelos de recuperação de formações ciliares. In: RODRIGUES, R.R.; LEITÃO-FILHO, H.F. (Ed.). Matas ciliares: conservação e recuperação. 3 ed. São Paulo: EDUSP, 2004. v.1, p.235-247.

BARBOSA, L.M.; ASPERTI, L.M.; BARBOSA, J.M. Características importantes de componentes arbóreos na definição dos estágios sucessionais em florestas implantadas. In: SIMPÓSIO INTERNACIONAL DE ECOSSISTEMAS FLORESTAIS, 4., Belo Horizonte, 1996. Anais. Belo Horizonte, 1996 p.242-245.

BAZZAZ, F.A. Plants in changing environments: linking physiological, population and community ecology. Cambridge: Cambridge University, 1996. 320 p.

BERTANI, D.F.; RODRIGUES, R.R.; BATISTA, J.L.F. et al. Análise temporal da heterogeneidade florística e estrutural em uma floresta ribeirinha. Revista brasileira de Botânica, v.24, n.1, p.11-23, 2001.

BOX, G.E.P.; HUNTER, W.G.; HUNTER, J.S. Statistics for experimenters. New York: John Wiley ,1978.

BUDOWSKI, G. Distribuition of tropical american rain forest in the light of successional process. Turrialba, v.15, n.1, p. 40-42, 1965.

CAMPOS, H. Estatística experimental não-paramétrica. Piracicaba: FEALQ, 1983. $349 \mathrm{p}$. 
CARDOSO, V.J.M. Dormência: Estabelecimento do processo. In: FERREIRA, A.G.; BORGHETTI, F. (Org.). Germinação: do básico ao aplicado. Porto Alegre: Artmed, 2004. p.95-108.

CARMO, M.R.C; MORELLATO, L.P.C. Fenologia de arvores e arbustos das matas ciliares da bacia do Rio Tibagi, Estado do Paraná, Brasil. In: RODRIGUES, R.R.; LEITÃO-FILHO, H.F. (Ed.). Matas ciliares: conservação e recuperação. 3.ed. São Paulo: EDUSP, 2004. v.1, p.235-247.

CÉSAR, O.; MONTEIRO, R. Florística e fitossociologia de uma floresta de restinga em Picinguaba (Parque Estadual da Serra do Mar), município de Ubatuba - SP. Naturalia, v.20, p.89-105, 1995.

CÉZAR, P.B.; OLIVEIRA,R.R. A Floresta da Tijuca e a cidade do Rio de Janeiro. Rio de Janeiro: Nova Fronteira, 1992. 172p.

CLEMENTS, F.E. Succession. Washington.: Carnegie Institution of Washington, 1916.

CLEMENTS, F. E. Plant succession and indicators: a definitive edition of plant succession and plant indicators. New York: Haffner Press, 1928. 453 p.

COMPANHIA DE CIMENTO RIBEIRÃO GRANDE. Ampliação da Mina Limeira: estudo de impacto ambiental. São Paulo, 2003. v.2, v.6

CONSELHO ESTADUAL DO MEIO AMBIENTE. Áreas naturais. São Paulo, 1985.

CORVELLO, W.B.V. Utilização de mudas da regeneração natural em reflorestamentos com espécies nativas. Curitiba: Universidade Federal do Paraná. 1983.

CRESTANA, M.S.M. Florestas: sistemas de recuperação com essências nativas. Campinas: CATI, 1993.

DALLING, J.W.; SWAINEL, M.D.; GARWOOD, N.C. Soil seed bank community dynamics in seasonally moist lowland tropical forest, Panamá. Jornal of Tropical Ecology, v. 13, p. 659-680, 1997.

DALE V.H.; BEYELER S.C. Challenges in the development and use of ecological indicators. Ecology Indicators, v.1, p.3-10,2001.

DENSLOW, J.S.; GOMEZ DIAS, A.E. Seed rain to tree-fall gapes in a neotropical rain Forest. Canadian Journal of Forest Research, v.20, p.642-648, 1990. 
DURIGAN, G.; NOGUEIRA, J.C.B. Recomposição de matas ciliares. Boletim do Instituto Florestal, v.4, n.1, p.14,1990. (Série Registros).

DURIGAN, G.; MELO, A.C.G.; MAX, J.C.M. et al. Manual para recuperação da vegetação de cerrado. 2.ed. São Paulo: Páginas \& Letras, 2003a.

DURIGAN, G.; MELO, A.C.G.; MAX, J.C.M. et al. Manual para recuperação das matas ciliares do oeste paulista. 2.ed. São Paulo: Páginas \& Letras, 2003 b.

ENGEL, V.L.; PARROTTA, J.A. Definindo a restauração ecológica: Tendências e perspectivas mundiais. In: KAGEYAMA, P.Y.; OLIVEIRA, R.E.; MORAES, L.F.D. et al. (Coord.). Restauração ecológica de ecossistemas naturais. Botucatu: FEPAF, 2003.

ENGEL, V.L.; MASSOCA, P.E.S.; PATRÍCIO, A.L.et al. Implantação de espécies nativas em solos degradados através de semeadura direta. In: SIMPÓSIO DE BIOLOGIA DA UNISANTA, 6., Santos, 2001. Anais.

FARAH, F.T. Favorecimento da regeneração de um trecho degradado de floresta estacional semidecidual. Campinas, 2003. Dissertação (Mestrado) - Instituto de Biologia, Universidade Estadual de Campinas.

FERRETTI, A.R.; KAGEYAMA, P.Y.; ARBOEZ, G.F. et al. Classificação das espécies arbóreas em grupos ecológicos para restauração com nativas no Estado de São Paulo. Florestar Estatístico, v.3 n.7, p.73 -77, 1995.

FIEDLER, P.L.; WHITE. P.S.; LEIDY, R.A. The paradigm shift in ecology and its implications for conservation. In: PICKETT, S.T.A.; OSTFELD, R. S.; SHACHAK, $M$. et al. The ecological basis of conservation: heterogenity, ecosystems and biodiversity. New York: Internacional Thomson Publ., 1997.

FIGLIOLIA, M.B. Colheita de sementes. In: SILVA, A.; PIÑA- RODRIGUES, F.C.M.; FIGLIOLIA, M.B. Manual técnico de sementes florestais. São Paulo: Instituto Florestal,1995. p. 98. (Série Registros).

FUNDAÇÃO PARA CONSERVAÇÃO E A PRODUÇÃO FLORESTAL DO ESTADO DE SÃO PAULO. Recuperação florestal: da muda à floresta. São Paulo: SMA, 2004. 112p. 
GABRIEL, J.L.C. Florística, fitossociologia de espécies lenhosas e aspectos da ciclagem de nutrientes em floresta mesófila semidecídua nos municípios de Anhenbi e Bofete, SP. Rio Claro,1997. 217p. Tese de (Doutorado) - Universidade Estadual Paulista "Júlio de Mesquita Filho".

GANDOLFI, S. Estudo florístico e fitossociológico de uma floresta Residual na Área do Aeroporto Internacional de São Paulo, município de Guarulhos, SP. Campinas, 1991. 232p. Dissertação (Mestrado) - Instituto de Biociências, Universidade Estadual de Campinas.

GANDOLFI, S.; LEITÃO-FILHO, H.F.; BEZERRA, C.L.F. Levantamento e caráter sucessional das espécies arbustivo-arbóreas de uma floresta mesófila semidecídua no município de Guarulhos, SP. Revista Brasileira de Botânica., v. 55, n.4, p.753-767, 1995.

GARWOOD, N.C. Tropical soil seed banks: a review. In: LECK, M.;PARKER, V.; SIMPSON, R. Ecology of soil seed banks. San Diego: Academic Press, 1989. p. 149-209.

GISLER, C.V.T. O uso da serapilheira na recomposição da cobertura vegetal em áreas mineradas de bauxita, Poços de Caldas, MG. São Paulo, 1995. 146p. Dissertação (Mestrado)- Instituto de Biociências, Universidade de São Paulo,

GROMBONE-GUARATINI, M.T.; RODRIGUES, R.R. Seed bank and seed rain in seasonal semi-deciduous Forest in south-eastern Brazil. Journal of Tropical Ecology, 18 p.759-774, 2002.

GUENJI, Y.; VILAS BÔAS, O. Manual de pequenos viveiros florestais. São Paulo: Páginas \& Letras Editora e Gráfica, 2003.

GUEVARA, S.; PURATA, S.E.; VAN DER MAAREL, E. The role remnant forest trees in tropical secondary succession. Vegetatio, v. 66, p.77-84, 1986.

GUIX, J.C. Intervales, a plenitude da Mata Atlântica. São Paulo: Fundação Florestal, 1994. 240p.

HATCHER, L.; STEPANSKI, E.J. A step-by-step approach to using the SAS system for univariate and multivariate statistics. Cary: SAS Institute, 1994. 
HOLTHUIJZEN, A.M.A.; BOERBOOM, J.H.A. The Cecropia sedbank in the Surinam lowland rain forest. Biotropica, v. 14, p. 62-68, 1982.

HUECK, K. As florestas da América do Sul. Trad. de H. Reichardt. São Paulo: Editora Polígono; EDUSP, 1972. 466p.

HYATT, L.; CASPER, B.B. Seed bank formation during early secondary succession in a temperate deciduous forest. Journal of Ecology, v.88, p.516-527, 2000.

IVANAUKAS, N.M. Levantamento florístico de trecho de Floresta Atlântica em Pariquera-Açu, São Paulo, Brasil. Naturalia, v, 26, p. 97-129, 2001.

KAGEYAMA, P.Y. Estudo para implantação de matas de galeria na bacia hidrográfica do Passa-Cinco visando utilização para abastecimento público. Piracicaba: ESALQ, 1986. 236 p.

KAGEYAMA, P.Y. Restauração da mata ciliar: manual para recuperação de áreas ciliares e microbacias. Rio de Janeiro: Semads. 2001. 104 p.

KAGEYAMA, P.Y; GANDARA, F. Recuperação de áreas ciliares. In: RODRIGUES, R.R.; LEITÃO-FILHO, H.F. (Ed.). Matas ciliares: conservação e recuperação. 3. ed. São Paulo: EDUSP, 2004. v.1, p.235-247.

KAGEYAMA, P.Y; VIANA, V.M. Tecnologia de sementes e grupos ecológicos de espécies arbóreas tropicais. In: SIMPÓSIO BRASILEIRO SOBRE TECNOLOGIA DE SEMENTES FLORESTAIS, São Paulo, 1989. Anais. São Paulo, 1989. p.19.

KAGEYAMA, P.Y.; CASTRO, C.E.A.; CARPANEZZI, A.A. Implantação de matas ciliares: estratégia para auxiliar a sucessão secundária. In: SIMPÓSIO SOBRE MATAS CILIARES, 1, Campinas, 1989. Anais. Campinas: Fundação Cargill, 1989. p.130-143.

KAGEYAMA, P.Y.; BIELLA, L.C.; PALERMO JUNIOR, A. Plantações mistas com espécies nativas com fins de proteção a reservatório. In: CONGRESSO FlOREStAl BRASILEIRO, 6., Campos do Jordão, 1990. Anais. São Paulo: Sociedade Brasileira de Silvicultura, 1990. v. 1, p. 109-112.

KAGEYAMA, P.Y.; OLIVEIRA, R.E.; MORAES, L.F.D. ET AL. Restauração ecológica de ecossistemas naturais. Botucatu: FEPAF, 2003. 
KAGEYAMA, P.Y.; SANTARELLI, E.; GANDARA, F.B. et al. Restauração de áreas degradadas: Modelos de consorciação com alta diversidade. In: SIMPÓSIO NACIONAL DE RECUPERAÇÃO DE ÁREAS DEGRADADAS, Foz do Iguaçu, 1994. Anais. 1994. p.569-576.

KLEIN, R.M. Aspectos dinâmicos da vegetação do Sul do Brasil. Sellowia, v.36, p.5-54, 1984.

KÖEPPEN, W. Climatologia. México: Fondo de Cultura Econômica, 1948. 478 p.

KORMAN, V.. Proposta de interligação das glebas do Parque Estadual de Vassununga (Santa Rita do Passa Quatro, SP). Piracicaba, 2003. 131p. Dissertação (Mestrado) Escola Superior de Agricultura “Luiz de Queiroz”, Universidade de São Paulo.

KRONKA, F.J.N.; MATSUKUMA, C.K.; NALON, M.A. et al. Inventário florestal do Estado de São Paulo. São Paulo: Instituto Florestal; CITDPA; Secretaria de Meio Ambiente, 1993.

LOPES, R.F.; BENINI, R. M.; RODRIGUES, R.R. et al. Programa de adequação ambiental da Fazenda Bela Vista - Usina Vertente Açúcar e Álcool Ltda. Piracicaba: ESALQ, LCB, LERF, 2004. 1v. (relatório técnico).

LORENZI, H. Árvores brasileiras: manual de identificação e cultivo de plantas arbóreas nativas do Brasil. 4 .ed. Nova Odessa: Instituto Plantarum, 2002. 1v.

MACEDO, A.C. Produção de mudas em viveiros florestais: espécies nativas. Revisado e ampliado por Paulo Y. Kageyama e Luiz G. S. Costa. São Paulo: Fundação Florestal, 1993a. 20p.

MACEDO, A.C. Restauração, matas ciliares e de proteção ambiental. São Paulo: Fundação Florestal, 1993b. 27 p.

MACEDO, A.C.; KAGEYAMA, P.Y.; COSTA, L. G. S. Regeneração: matas ciliares e de proteção ambiental. São Paulo: Fundação Florestal, 1993. 26 p.

MANHÃES, M.A. Diet of Tanagers (Passeriformes, Emberizidae) in Ibitipoca State Park, Minas Gerais, Brazil. Iheringia, Sér. Zool., v.93, n.1, p.59-73, 2003.

MANTOVANI, W. A paisagem dinâmica. São Paulo: Fundação Florestal, 1994. 240p. 
MANTOVANI, W.; RODRIGUES, R.R.; ROSSI, L. et al. A vegetação na Serra do Mar em Salesópolis, SP. In: SIMPÓSIO DE ECOSSISTEMAS DA COSTA SUL E SUDESTE BRASILEIRA: ESTRUTURA, FUNÇÃO E MANEJO, 2., Águas de Lindóia, 1990 Anais. São Paulo: ACIESP, 1990. p. 348-384.

MARTÍNEZ-RAMOS, M.; SOTO-CASTRO, A. Seed rain and advanced regeneration in a tropical rain Forest. Vegetatio, v.107/108, p.299-318, 1993.

MARTINS, S.V.; RODRIGUES, R.R. Gap-phase regeneretion in a semideciduos mesophytic Forest, south-eastern Brazil. Plant Ecology, v.163, p.51-62, 2002.

MELO, V.A. Poleiros artificiais e dispersão de sementes por aves em uma área de reflorestamento, no Estado de Minas Gerais. Viçosa, 1997. Dissertação (M.S.) Universidade Federal de Viçosa.

MIRITI, M.N. Regeneração florestal em pastagens abandonadas na Amazônia central: competição, predação e dispersão de sementes. In: GASCON, C.; MOUTINHO, P. (Ed.). Floresta Amazônica: dinâmica, regeneração e manejo. Manaus: INPA, 1998. cap 12, p. 179-190.

MOREIRA, A.G.; RIBEIRO, J.F.; KLINK, C.A. O banco de sementes de Emmotum nitens (Benth.) Miers em um Cerradão de solos distróficos. In: CONGRESSO DA SOCIEDADE BOTÂNICA DE SÃO PAULO, 4., Brasília, 1996. Programas e Resumos. Campinas: UNICAMP; Sociedade Botânica de São Paulo. 1986. p.82.

MUELLER DOMBOIS, D.; ELLEMBERG, H. Aims and methods of vegetation ecology. New York: John Wiley, 1974. 574p.

NAVE, A.G. Determinação de unidades ecológicas num fragmento de floresta nativa, com auxílio de sensoreamento remoto. Piracicaba, 1999. 167p. Dissertação (Mestrado) - Escola Superior de Agricultura "Luiz de Queiroz”, Universidade de São Paulo.

NEPSTAD, D.C.; UHL, C.; PEREIRA, C.A. et al. Estudo comparativo do estabelecimento de árvores em pastos abandonados e florestas adultas da Amazônia oriental. In: GASCON, C.; MOUTINHO, P. (Ed.). Floresta Amazônica: dinâmica, regeneração e manejo. Manaus: INPA, 1998. cap 12, p. 191-218.

NIMER, E. Climatologia do Brasil. Rio de Janeiro: IBGE, 421p. 1989. 
NOGUEIRA, J.C.B. Reflorestamento heterogêneo com essências indígenas. Boletim Técnico do Instituto Florestal, n.24,1977.

NOSS, R.F. Corridors in real land-scapes: A reply to Simberloff and Cox. Conservation Biology, v.1 n.2, p.159 - 164, 1987.

ODUM, E.P. The strategy of ecosystem development. Science, v.164, p.262-270, 1969.

PAREJA, E.K. Utilização de banco de plântulas das espécies Emmotum nitens, Ocotea spixiana e Mouriri elliptica na recuperação de áreas degradadas do cerrado. Tocantins, 1998. Monografia (Graduação) - Faculdade de Agronomia, Universidade de Tocantins.

PARROTA, J.A. Influence of overstory composition on understory colonization by native species in plantations on a degraded tropical site. Journal of Vegetation Science, v.6, p. 627-636, 1995.

PARROTA, J.A.; TURNBULL, J.W.; JONES, N. Catalyzing native forest regeneration on degraded tropical lands. Forest Ecology and Management, v. 99, p. 1-7, 1997.

PEDERSON, R.L.; VAN DER VALK, A.G. Seed banks and the management and restoration of natural vegetation. In: LECK, M.A.; PARKER, J.T.; SIMPSON, R.L. (Ed.). Ecology soil seed banks. San Diego: Academic Press, 1989. p. 329-346.

PICKETT, S.T.A.; OSTFELD, R. S. The shifiting paradigm in ecology. In: KNIGHT, R.L.; BATES, S.F. (Ed.). A new century for natural resources management. Washington: Island Press, 1994. p.261-278.

PICKETT, S.T.A.; THOMPSON, J.N. Patch dynamics and the design of nature reserves. Biological Conservation, v.13, p.27-37, 1978.

PICKETT, S.T.A.; COLLINS, L.S; ARMESTO, J.J. A hierachical consideration of causes and mechanismics of succession. Vegetatio, v. 69, p109-114, 1987.

PICKETT, S.T.A; PARKER, V.T.; FIEDLER, L. The new paradigm in ecology: Implications for conservation biology above the species level. In: FIEDLER, L.; JAIN, S.K. (Ed.). Conservation biology: the theory and practice of nature conservation, and management. New York: Chapman and Hall, 1992. p.65 - 68.

PROCTOR, M.; YEO, P.; LACK, A. The natural history of pollination. London: Harper-Collins Publ., 1996. 
REICHMAMM NETO, F. Revegetalização de áreas marginais e reservatórios de hidroelétricas. In: CONGRESSO FLORESTAL BRASILEIRO, 4., Manaus, 1978. Anais. São Paulo: Sociedade Brasileira de Silvicultura, 1978. p. 215-217.

REIS, M.S. Distribuição e Dinâmica da Variabilidade Genética em Populações Naturais de Palmiteiro (Euterpe edulis Martius). Piracicaba, 1996. Tese de (Doutorado) Escola Superior de Agricultura Luiz de Queiroz”, Universidade de São Paulo.

REIS, M.S.; REIS, A.; RIBEIRO, R. J. Desenvolvimento sustentável e o palmiteiro. São Paulo: Fundação Florestal, 1994. 240p.

RODRIGUES, R.R. Métodos fitossociológicos mais usados. Casa da Agricultura, v. 10, n.1, p. 20-24, 1988.

RODRIGUES, R.R. Análise da vegetação às margens do Rio Passa Cinco Ipeúna, SP. Campinas, 1992 334p. Tese (Doutorado) - Instituto de Biologia, Universidade Estadual de Campinas.

RODRIGUES, R.R. Colonização e enriquecimento de um fragmento florestal urbano após a ocorrência de fogo, fazenda Santa Elisa, Campinas SP: avaliação temporal da regeneração natural (66 meses) e do crescimento (51 meses) de 30 espécies florestais plantadas em consórcios sucessionais. Piracicaba, 1999. 167p. Tese (LivreDocência) - Escola Superior de Agricultura "Luiz de Queiroz", Universidade de São Paulo.

RODRIGUES, R.R.; GANDOLFI, S. Recomposição de florestas nativas: princípios gerais e subsídios para uma definição metodológica. Revista Brasileira de Horticultura Ornamental, v.2, n.1, p.4-15, 1996.

RODRIGUES, R.R.; SHEPHERD, G. Fatores condicionantes da vegetação ciliar. In: RODRIGUES, R.R.; LEITÃO-FILHO, H.F. (Ed.). Matas ciliares: conservação e recuperação. 3.ed. São Paulo: EDUSP, 2004. v.1, p.235-247.

RODRIGUES, R.R.; LEITÃO-FILHO, H.F.; CRESTANA, M.S.M. Recomposição artificial da mata ciliar ao redor da represa de abastecimento de água do município de Iracemápolis, SP. Iracemápolis: Prefeitura Municipal de Iracemápolis, 1987. 
RODRIGUES, R. R.; GANDOLFI, S. Restauração de florestas tropicais: subsídios para uma definição metodológica e indicadores de avaliação e monitoramento. In: DIAS, L.E.; MELLO, J.W.V. (Ed.). Recuperação de áreas degradadas. Viçosa: Sociedade Brasileira de Recuperação de Áreas Degradadas, 1998. p. 203-215.

RODRIGUES, R.R.; GANDOLFI, S. Conceitos, tendências e ações para a recuperação de florestas ciliares In: RODRIGUES, R.R.; LEITÃO-FILHO, H.F. (Ed.). Matas ciliares: conservação e recuperação. 3.ed. São Paulo: EDUSP, 2004. v.1, p.235-247.

RODRIGUES, R.R.; NAVE, A.G. Heterogeneidade florística das mata ciliares. In: RODRIGUES, R.R.; LEITÃO-FILHO, H.F. (Ed.). Matas ciliares: conservação e recuperação. 3.ed. São Paulo: EDUSP, 2004. v.1, p.235-247.

RODRIGUES, R. R.; LEITÃO-FILHO, H.F.; CRESTANA, M.S.M. Revegetação do entorno da represa de abastecimento de água do município de Iracemápolis, SP. In: SIMPÓSIO NACIONAL: RECUPERAÇÃO DE ÁREAS DEGRADADAS. Curitiba, 1992. Anais. Curitiba: Universidade Federal do Paraná, 1992. p.407-416.

RODRIGUES, R.R.; GANDOLFI, S.; NAVE, A.G. et al. Programa de adequação ambiental das áreas agrícolas da Cia Açucareira Vale do Rosário. Piracicaba: ESALQ, Depto Ciências Biológicas, 2001. (relatório técnico).

RODRIGUES, R R.; GANDOLFI, S.; NAVE, A. G. Programa de adequação ambiental de estações experimentais do Instituto Florestal. Piracicaba: FEALQ; ESALQ, 2003a. 64p. (relatório técnico).

RODRIGUES, R. R.; GANDOLFI, S.; NAVE, A. G. Programa de adequação ambiental das áreas agrícolas da Usina Moema Açúcar e Álcool Ltda. fase II.. Piracicaba: ESALQ, LCB, LERF, 2003b. 103p. (relatório técnico).

RODRIGUES, R.R.; GANDOLFI, S.; NAVE, A.G. Programa de adequação ambiental das áreas agrícolas da Usina Cerradinho de Açúcar S/A e Acionistas. Piracicaba: ESALQ, LCB, LERF, 2003c. 110p. (relatório técnico).

RODRIGUES, R.R.; MARTINS, S.V.; BARROS, L.C. Tropical rain Forest regenerenation in area degraded bymining in Mato Grosso, State Brazil. Forest Ecology and Management, v. 190 n 2/3, p.323-333, 2004a. 
RODRIGUES, R.R.; GANDOLFI, S.; NAVE, A.G. et al. Programa de adequação ambiental das áreas agrícolas da Usina Jardest SA - Açúcar e Álcool, Jardinópolis, SP. Piracicaba: ESALQ, Depto Ciências Biológicas, 2004b. (relatório técnico).

ROZZA, A.F. Florística, fitossociologia e caracterização sucessional em uma floresta estacional semidecidual: Mata da Vírginia, Matão, SP. Campinas, 1997. 176p. Dissertação (Mestrado) - Instituto de Biologia, Universidade Estadual de Campinas.

SALOMÃO, A. N.; SOUZA-SILVA, J.C.; DAVIDE, A.C. et al. Germinação de sementes e produção de mudas e plantas do cerrado: rede de sementes do cerrado. Brasília: Versata, 2003. v.1, 96 p.

SAS INSTITUTE. The SAS system realease 8.2. Cary, 1999.

SEITZ, R. A. As potencialidades da regeneração natural na recuperação de áreas degradadas. In: RECUPERAÇÃO DE ÁREAS DEGRADADAS. CURSO DE ATUALIZAÇÃO, 3., Curitiba, 1996. Curitiba: UFPR, 1996. p. 45-51.

SETZER, J. Atlas climático e ecológico do Estado de São Paulo. São Paulo: Comissão Interestadual da Bacia Paraná-Uruguai; Cesp, 1966. 232 p.

SHEPHERD, G.J. FITOPAC 1: manual do usuário. Campinas: UNICAMP, Departamento de Botânica, 1995. 80 p.

SILVA, W.R. A importância das interações planta-animal nos processos de restauração. In: KAGEYAMA, P. (Coord.). Restauração ecológica de ecossistemas naturais. Botucatu: FEPAF, 2003. p.77-90.

SIQUEIRA, L.P. Monitoramento de áreas restauradas no interior do Estado de São Paulo, Brasil. Piracicaba, 2002. 116 p. Dissertação (Mestrado) - Escola Superior de Agricultura “Luiz de Queiroz", Universidade de São Paulo.

SKOGLUND, J. The role of seed banks in vegetation dynamics an restoration of dry tropical ecosystems. Journal of Vegetation Science, n.3, p.357-360, 1992.

SOUZA, F.M.; BATISTA, J.L.F. Restoration of seasonal semideciduous forests in Brazil: influence of age and restoration design on forest structure. Forest Ecology and Management. v.191, p. 185-200, 2004. 
SOUZA, S.C.P.M. Análise de alguns aspectos de dinâmica florestal em uma área degradada no interior do Parque Estadual do Jurupará, Ibiúna, São Paulo. Piracicaba, 2002. 96p. Dissertação (Mestrado). Escola Superior de Agricultura "Luiz de Queiroz”, Universidade de São Paulo.

THOMA, A.C. Sobrevivência e desenvolvimento inicial de plântulas de Tapirira guianensis Aulb. E Cheiloclinum cognatum (Miers.) A. C. Smith, após transferência direta para campo e viveiro. Gurupi, Tocantis, 1998. (Monografia.) - Faculdade de Agronomia, Universidade de Tocantins

TOLEDO, RE.B.; DINARDO, W.; BEZUTTE, A.J. et al. Efeito da densidade de plantas de Brachiaria decumbens Stapf sobre o crescimento inicial de mudas de Eucalyptus grandis W.Hill ex Maiden. Scientia Forestalis, n. 60, p. 109-117, dez. 2001.

TONIATO, M.T.Z. Variações na composição e estrutura da comunidade arbórea de um fragmento de floresta semidecidual em Bauru (SP), relacionadas a diferentes históricos de perturbações antrópicas. Campinas, 2001. Tese de (Doutorado) Instituto de Biologia, Universidade Estadual de Campinas.

TROPPMAIR, H. A cobertura vegetal primitiva do Estado de São Paulo. Biogeografia, V.1, p. 1-10, 1969.

TUCKER, N.I.J.; MURPHY, T.M. The effects of ecological rehabilitation on vegetation recruitment: some observations from the wet tropics of North Queensland. Forest Ecology and Management, v. 99, p. 133-152, 1997.

VAN DER PIJL, L. Principles of dispersal in higher plants. Berlin: Springer-Verlag. 1969.

VIANI, R. Uso da regeneração natural (floresta estacional semidecidual e talhões de eucalyptus), como estratégia para produção de mudas e resgate da diversidade vegetal na restauração florestal, bofete (sp). Campinas. Dissertação (Mestrado) Universidade de Campinas. No prelo.

VICTOR, M.A.M. A devastação florestal. São Paulo: Sociedade Brasileira de Silvicultura, 1975. 
VIEIRA, D.C.M. Chuva de sementes, banco de sementes e regeneração natural sob três espécies de início de sucessão em uma área restaurada em Iracemápolis (SP). Piracicaba, 2004. Dissertação (Mestrado) - Escola Superior de Agricultura "Luiz de Queiroz”, Universidade de São Paulo.

WHITMORE, T.C. Gaps in the Forest canopy. In: TOMLINSON, P.B.; ZIMMERMANN, M.H. Tropical trees as living systems. Cambridge: Cambridge University Prees, 1976. p.639-649.

WHITMORE, T.C. On pattern and process in forest. In: NEWMAN, F.I. (Ed.). Special publication 1. Oxford: Blackwell Scientific Publications. 1982. p.45-59. (Series of the British Ecological Society)

WHITMORE, T.C. Forty years of rain forest ecology: 1948-1988 in perspective. Geojournal, v.19 n.4, p. 347-360, 1989.

WHITTAKER, R.H. Evolution and measurement of species diversity. Taxon, v.21, p.213-251. 1972.

WUNDERLE JUNIOR., J.M. The role of animal seed dispersal in accelerating native forest regeneration on degraded tropical lands. Forest Ecology and Management, v. 99, p.223-235, 1997.

YAMAZOE, G.; VILAS-BÔAS, O. Manual de pequenos viveiros florestais. São Paulo: Páginas e Letras Editora e Gráfica, 2003. 120p.

ZAR, J.H. Biostatistical analysis. Englewood Cliffs: Prentice-Hall, 1999. 